Department of The INTERIOR

Hubert Work, Secretary

U. S. GEOLOGICAL SURVEY

George Otis Smith, Director

Bulletin 782

\title{
ORE DEPOSITS OF THE \\ JEROME AND BRADSHAW MOUNTAINS \\ QUADRANGLES, ARIZONA
}

\author{
BY \\ WALDEMAR LINDGREN \\ WITH STATISTICAL NOTES BY \\ V. C. HEIKES
}

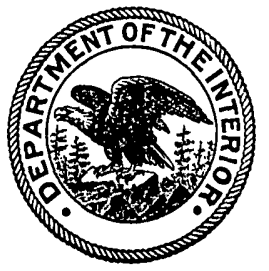

WASHINGTON

GOVERNMENT PRINTING OFFICE 
ADDITIONAL COPIES

OF THIS PUBLICATION MAY BE PROCURED FROM THE SUPERINTENDENT OF DOCUMENTS GOVERNMENT PRINTING OFFICE

WASHINGTON, D. C.

AT

50 CENTS PER COPY

$\nabla$ 


\section{CONTENTS}

Introduction

History of mining

Production

Mining districts near area here described

General geology---1- 7

Physiography

Paleozoic sediments_-_._- 9

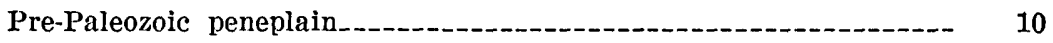

Relation of the plateau province to the mountain region.......- 10

Post-Paleozoic erosion_-_-_-_._- 13

Volcanic flows_-. 13

Verde formation

Latest formations.-_-_-_- 14

Pre-Cambrian rocks__._._._.

General features_..-_- 14

Dike intrusions_._- 16

Bradshaw granite-_._-

Diorite and monzonite_-_._-_._-_._- 17

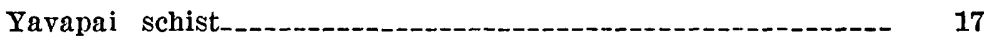

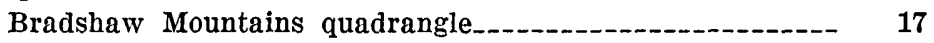

Jerome quadrangle_.._-_._- 19

Correlation

Rocks of doubtful age-_-_- 21

Granodiorite (quartz diorite) -..-_-_-_-_- 21

Basic dike rocks_-_._- 22

Dikes of rhyolite porphyry-_-_-_-_- 22

Ore deposits_........ 24

Minerals of the ore deposits____._- 24

General classification

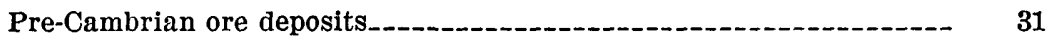

Pyritic copper deposits in schist______

General character and form

Character of replacement.

Origin of the replacement deposits_-_-_._- 35

Magnetite deposits_-_-_-_- 35

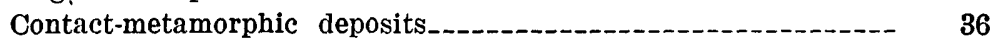

- Gold-quartz-tourmaline replacement deposits_-_-_-_-_-_-_-_- $\quad 37$

Gold quartz veins_._._. 37

General character._........ 37

Production

Distribution

Strike, dip, and thickness._._. 39

Mineralization

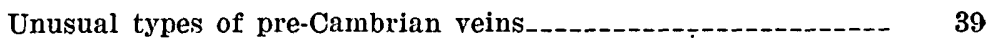

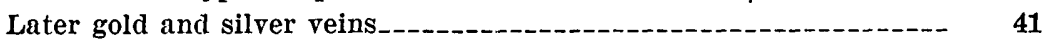

General features_-_._- 43 
Ore deposits-Continued.

Later gold and silver veins-Continued. Page

Silver veins_-_-_._-_._. 43

Veins with barite-_-_-_-_-_-_- 43

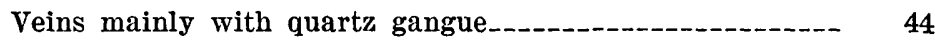

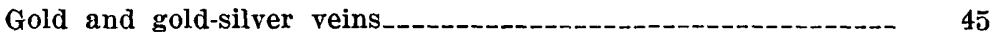

Proportion of gold to silver._-_._. 45

Associated rocks_-_-_-_-_-_-_-_-_- 45

Mineralization_-_-_-_._- 46

Distribution

Ore shoots_-_-_- 47

Unusual types_-_-_-_- 48

Water level and oxidation._- 49

Chalcocite zones_-_._- 50

Persistence in depth._- 51

Placer deposits_-_-_-_-_- 53

Detailed descriptions_-_-_-_- 54

Verde district_-_._- 54

Situation

General geology

Pre-Cambrian rocks_-_-_-_-_-_-_- 56

Paleozoic sediments_-_-_-_-_- 58

Tertiary lavas_____- 59

Tertiary lake beds_._- 59

Ore deposits_-_-_-_- 60

United Verde mine-_._- 61

Location

History - 61

Production -

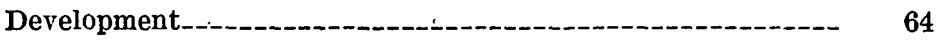

Precipitation of copper-_.-_- 65

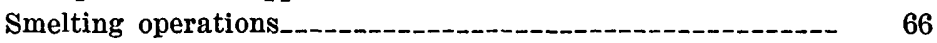

Mine water-_._- 66

Geology

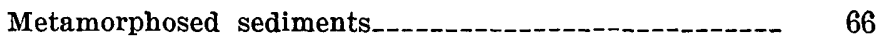

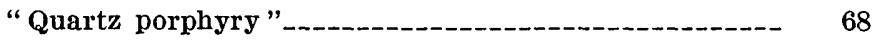

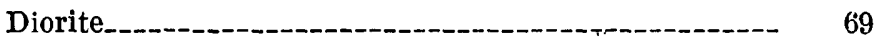

Dike rocks___-_._- 69

The ore body-_-_- 69

Local ore classification

The ores in detail

General character._-_._- 71

Paragenesis of minerals_-_-_-_- 72

Types of pyritic ores_-___- 73

Oxidized ores__- 75

Origin of the deposit_-_-_- 76

United Verde Extension Mining Co_-_-_-_-_-_-_-_-_-_-_ 79

Location and history-_-_. 79

Developments.-_-_-_._- 81

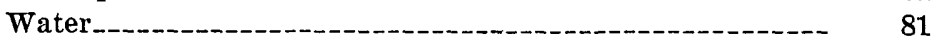

Production and dividends._._._._._._- 82

Geology-_-_-_-_- 82

Ore bodies_._- 83

The ore

Origin of the ore 
Detailed descriptions-Continued.

Verde district-Continued. Page

Jerome-Verde Development Co-_-_-_-_-_-_-_-_-_-_-_ 88

Dundee-Arizona Copper Co

Copper Chief Mining Co

Equator Mining \& Smelting Co

Shea Copper Co

Prospecting operations in the Verde district__._._._._._._._. 93

Black Hills district_____-_._._. 97

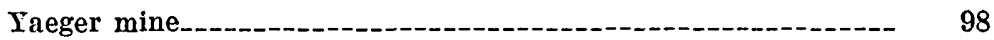

Shylock mine_-_-_-_-_._- 99

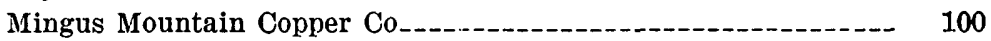

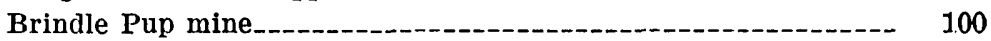

Black Warrior prospect._-_-_-___-_-_-_-_-_-_-_-_-_-_-_-_-_ 101

Other prospects_.._._._._- 101

Cherry Creek district_-_._. 102

Geology

Quartz veins_-_._- 103

History -.-- 104

Monarch mine_-_-_._- 105

Mines near the Monarch

Golden Idol mine_-_-_-_-_-_-_- 106

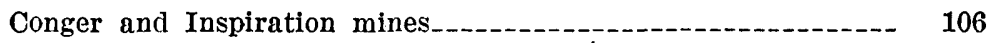

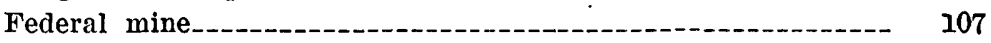

Leghorn mine_-_._. 107

Logan mine

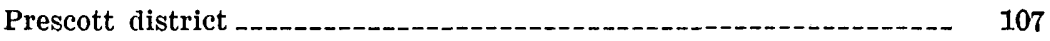

Geology -...- 107

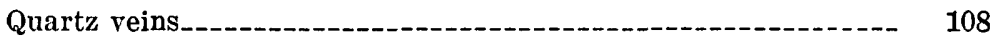

Placer deposits_... 108

Walker district_-_-_. 109

Sheldon mine._.-_- 110

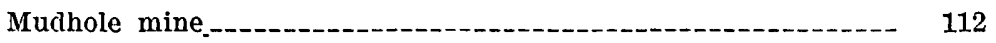

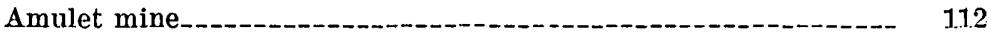

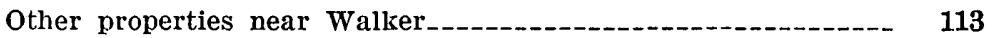

Properties north of Walker._._._._. 113

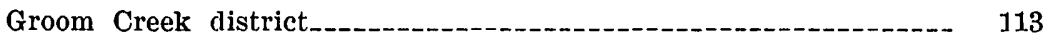

Hassayampa district._._-_._-_._-_._- 114

Big Pine mine

Ruth mine-_-_-_-_-

N. C. 4 mine

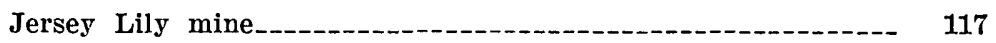

Blue Dick and Mark Twain mines___._._._._._._._._._._._. 117

Buzzard mine _-_-_-_-_-_-_._._._. 118

Dos Oris mine._._. 118

Davis mine

Dunkirk mine -

Tillie Starbuck mine-_-_._- 119

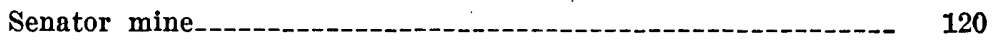

Cash mine -

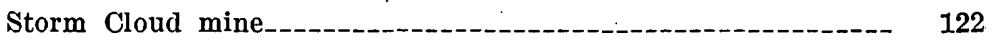

Mines near Chicago mill_-_-_- 123

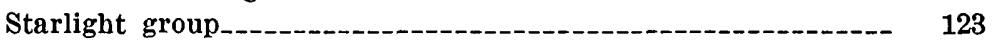


Detailed descriptions-Continued.

Hassayampa district-Continued.

Crook vein

Mount Union mine_..._- 125

Consolidated Bodie mine

Other properties

Bigbug district

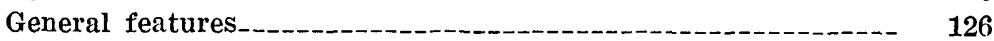

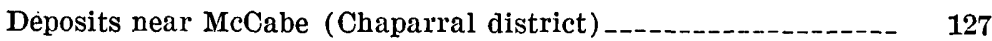

Iron King mine_._-_-_._- 127

Silver Belt mine_-_-_-_-_-_-_._- 128

Arizona National mine-_._._.

Lookout mine _._._- 130

McCabe-Gladstone mine

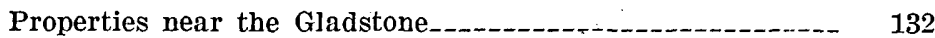

Union mine -

Properties on Bigbug Creek near Providenee and Poland_...... 134

Henrietta mine____._. 137

Boggs mine -

Iron Queen mine

Hackberry mine__._. 141

Butternut mine-_-_-_-_.-_ 142

Pocahontas mine_-_._._. 142

Blue Bell mine_-_._-_._-_._._. 143

History -_-_. 143

Development _._._- 143.

Production -_.

Geology

The ore body

Structure -

The ore -._-_-

Oxidation and water

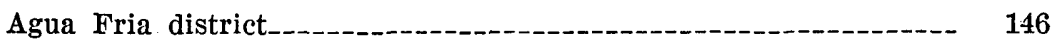

General features_-_-_-_-_._- 146

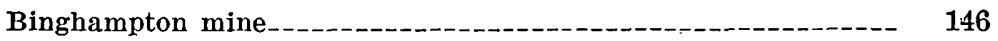

Equipment and production

Geology -._-

The ore

Oxidation and water-_._-_._-_._- 147

Copper Queen mine_-_._- 148

Stoddard mine

Other properties_-_-_-_- 148

Turkey Creek district

General features._......- 149

Cumberland mine._._. 150

Copper deposit_._. 150

War Eagle mine_-_-_._-_._- 150

Gold Note group_-_-_._- 151

Goodwin properties_.-_- 151

Morgan mine_._. 152

Black Canyon district.-_-_-_-_- 152

Topography and geology_-_._._- 152

Rainbow lode -

Pyritic deposits east of Turkey Creek station_____-_._- 154 
Detailed descriptions-Continued.

Black Canyon district-Continued.

Howard Copper Co.

Kay Copper Corporation.

Magnetite deposits

Pre-Cambrian quartz veins

Richinbar mine

Placers._._. 157

"Gold belt" near Turkey Creek station.-. 158

Silver Cord vein

Thunderbolt mine -

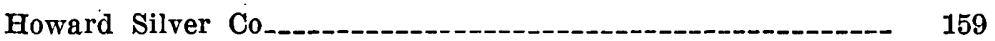

French Lily mine_-_._-_._-_._- 159

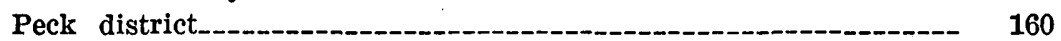

Properties south of the Peck mine-_-_-_-_-_-_-_-_-_-_- 160

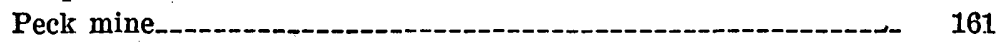

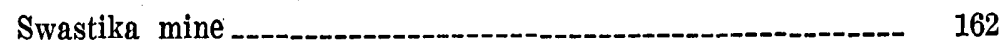

De Soto mine

Other properties_-_.

Pine Grove district_-_-_-_-_._- 164

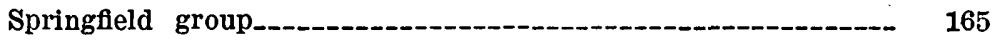

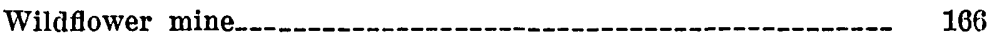

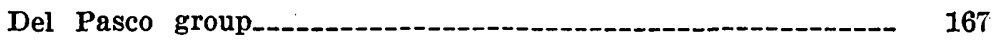

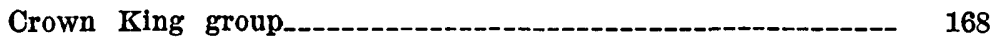

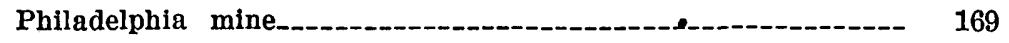

Fairview tunnel

Lincoln mine_-_-_-_.-_- 170

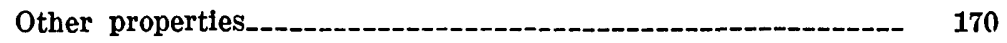

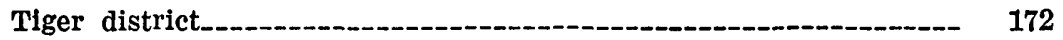

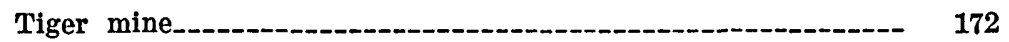

M. \& M. vein

Oro Belle and Gray Eagle mine-_-_-_-_-_-_-_-_-_-_-_-_-_--- 174

Northward extensions of Gray Eagle lode_..._._._._._._._._._. $\quad$ 175

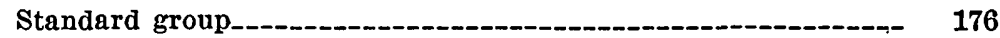

Bradshaw district _...--_..-_. 176

Minnehaha Flat and Silver Mountain_-_-_-_-_-_-_-_-_-_-_-_-_ 176

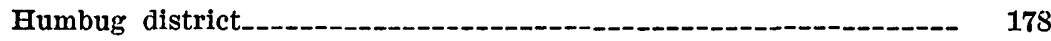

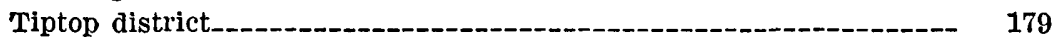

Topography and geology_-_._- 179

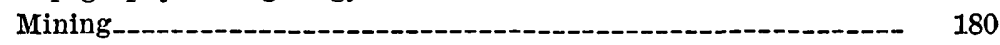

Tiptop mine__.

Seventy-six vein._._._.

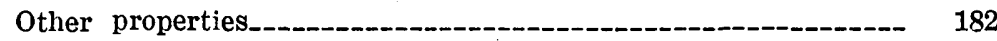

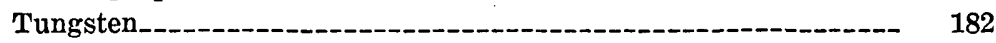

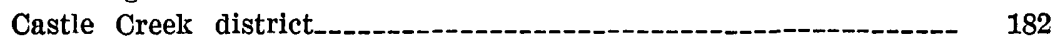

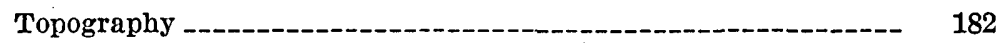

Geology

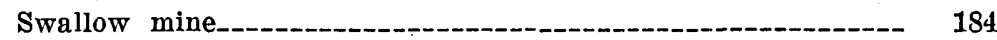

Whipsaw mine -.-.--_- 185

Other properties

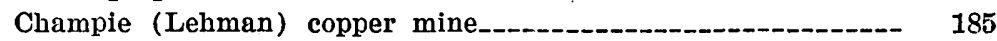

Copperopolis _-_-_._.

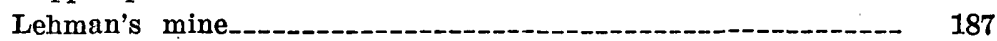

Index._-_-_. 189 


\section{ILLUSTRATIONS}

Page.

Plate 1. Geologic map of the Jerome quadrangle_._-__- In pocket.

2. Geologic map of the Bradshaw Mountains quadrangle

3. $A$, Silver Mountain, looking east from hill near Copperopolis; $B$, Bradshaw Mountains, looking northeast from point near Goddard's ranch

4. Panoramic view of Jerome district, on east slope of Black Hills

5. $A$, Photomicrograph of thin section showing Yavapai schist; $B$, Photomicrograph of thin section showing granodiorite of Walker district.

6. Property map of the Verde district.

7. Photomicrographs of thin sections showing pyritic ore from United Verde mine: $A$, Ore from 500-foot level; $B$, Ore from 1,000-foot level

8. Photomicrographs of thin sections showing pyritic ore from United Verde mine: $A$, Ore from 1,650-foot level; $B$, Ore from 650-foot level

9. Photomicrographs of thin sections showing ores: $A$, Pyritic ore from 1,500-foot level, United Verde mine; $B$, Ore from 1,000-foot level, Blue Bell mine

10. Photomicrographs of polished sections showing ores: $A$, Ore from Copper Chief tunnel; $B$, Ore from stopes above 300 . foot level, United Verde mine

11. Photomicrographs of polished sections showing ores from United Verde mine: $A$, Ore from 1,650-foot level; $B$, Ore from 500-foot tunnel at beginning of ore body

12. $A$, View looking east from Jerom: across Verde Valley; $B$, View looking north from Bigbug Creek

13. Photomicrographs of polished sections showing ore from 1,650 foot level, United Verde Extension mine

14. Photomicrographs of polished sections showing ores: $A$, Ore from Cash mine; $B$, Oxidized ore from Cougar vein 75 feet below surface.

15. Photomicrographs of polished sections showing ores: $A$, Ore from Swallow mine, Castle Creek district; $B$, Ore from Iron Queen mine, Mayer.

16. Longitudinal section of Blue Bell mine

17. Photomicrographs of polished sections showing ores: $A$, Ore from De Soto mine; $B$, Ore from Blue Bell mine

18. $A$, View looking south from Blue Bell mine across Turkey Creek toward Bradshaw Mountains; $B$, Binghampton mine. Agua Fria district.

19. $A$, Mill of Arizona-Binghampton Co., Agua Fria district; $B$, Outcrops of Yavapai schist in Black Canyon........-..- 
Plate 20. A, Quartzite outcrops in Yavapai schist on road from Mayer to Stoddard; $B$, Yavapai schist showing "gravestone" outcrops on road from Mayer to Stoddard.

, View looking up Black Canyon; $B$, View looking northeast from Crown King station toward Crazy Basin

22. Map showing location of claims in Pine Grove and Tiger districts

23. A, View looking north toward Lehman Mountain from Copperopolis; $B$, View looking south from Copperopolis toward the rhyolite flows

Frgure 1. Index map of Arizona showing location of region examined.-

2. Location of shafts and tunnels, United Verde mine

3. Geologic plan of typical mine level, United Verde mine.

4. Generalized vertical section of United Verde mine in plane of pitch

5. Section showing outcrop of United Verde mine and proposed operations of steam shovel

6. Plan of initial workings of mine of United Verde Extension $\mathrm{Co}$

7. Section of ore from Cash mine

8. Longitudinal section of McCabe-Gladstone mine-_-_-_-_-_---- 131

9. Longitudinal section of Henrietta mine

10. Longitudinal section of ore lenses in De Soto mine

$68508-26-2$ 



\title{
ORE DEPOSITS OF THE JEROME AND BRADSHAW MOUNTAINS QUADRANGLES, ARIZONA
}

\author{
By WaLdemar Lindaren
}

\section{INTRODUCTION}

In the summer of 1922, at the request of the Director of the United States Geological Survey, I undertook an examination of the ore deposits in the Jerome and Bradshaw Mountains quadrangles, Ariz. (See fig. 1.) The object of this work was not a detailed investigation of each deposit but rather a coordination and classification of the occurrences and an attempt to ascertain their origin and economic importance. Almost all the deposits occur in pre-Cambrian rocks or in rocks that are not readily/differentiated from the preCambrian. In the northern part of the Jerome quadrangle there are large areas of almost horizontal Paleozoic beds, and in both quadrangles there are also large areas of lava flows of Tertiary age. Finally there are wide spaces occupied by Tertiary tuff and limestone, or by Tertiary and Quaternary wash filling the valleys between the mountain ranges. But all these rocks except the pre-Cambrian are practically barren of ore deposits, and the problem therefore narrowed itself to an examination of the pre-Cambrian areas. This task was greatly facilitated by the careful work of Jaggar and Palache, set forth in the Bradshaw Mountains folio, ${ }^{1}$ in which the southern quadrangle of the two under present consideration is mapped geologically and described, and which also includes a comprehensive though brief discussion of the mineral deposits. There is no published geologic map of the Jerome quadrangle, but I had the opportunity through the courtesy of Dr. G. M. Butler, Director of the Arizona Bureau of Mines, to use a manuscript map of this area prepared for the State by Mr. L. E. Reber, jr., and Mr. Olaf Jenkins.

It would have been desirable to include the Congress quadrangle, to the west, in this reconnaissance, but the time and funds available did not permit this work. The topographic maps of the two quadrangles examined are of conspicuous excellence and reflect great

\footnotetext{
'Jaggar, T. A., Jr., and Palache, Charles, U. S. Geol. Survey Geol. Atlas, Bradshaw Mountains follo (No. 126), 1905.
} 
credit on Messrs. Matthes, Bannon, Dunnington, Evans, and Stiles, who surveyed the areas. The geologic map of the Jerome quadrangle accompanying this bulletin (pl. 1) has been compiled from the sources above indicated. The geologic map of the Bradshaw Mountains quadrangle, which forms Plate 2, has been taken from the Bradshaw Mountains folio. For assistance in the field I am indebted to Mr. A. B. Colwell, of Jerome, and for help in the study of ores to Dr. H. C. Boydell, of Cambridge, Mass.

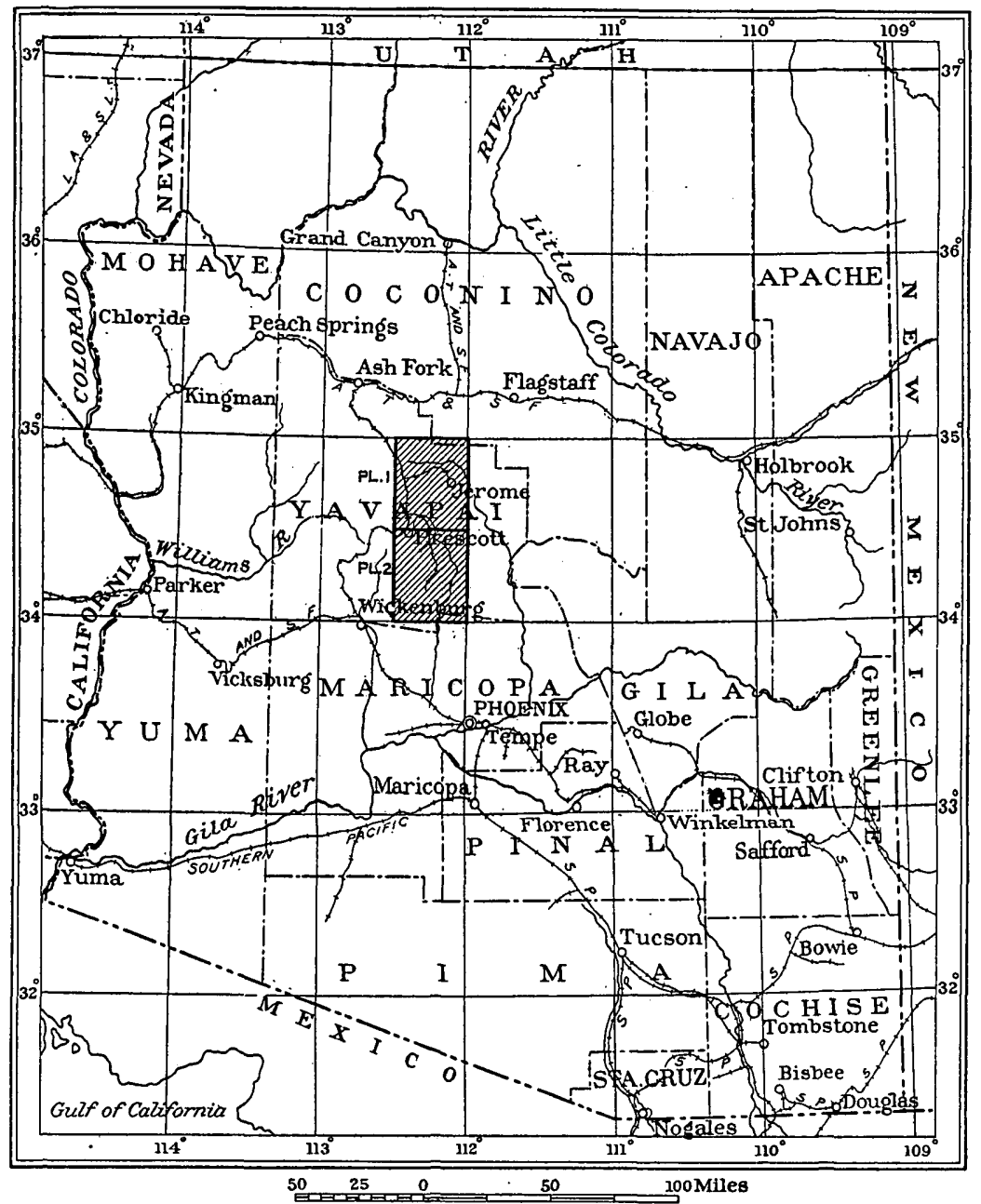

H'IGURE 1.-Index map of Arizona showing location of region examined

\section{HISTORY OF MINING}

At an early date, about 1863 , the Bradshaw Mountains were invaded by gold-seeking placer miners from California. They found some gold deposits of value along Hassayampa River and Lynx Creek and at other places, but compared to those of California the 
gravels were not rich, and this early placer mining left no permanent imprint on the region. Conditions were unfavorable as to transportation, and mining was handicapped by hostile Indians.

The first lode mining began about 1875 , when many of the rich silver-gold mines were located-for instance, the Tiger, Tiptop, War Eagle, Del Pasco, Peck, Silver Belt, and Bigbug. The earliest locations in the Verde district, near Jerome, are said to have been made in 1876. This second epoch of discoveries and mining was initiated by prospectors from the Comstock and other recently discovered rich silver camps in the Western States. The development mas, of course, stimulated by the building of the Southern Pacific ind Atchison, Topeka \& Santa Fe railroads in 1881. The transportation of ore, which had been laboriously and expensively sent to Swansea, Wales, by way of Colorado River and the Gulf of California, now became easier, and the shipments were sent to Denver and San Francisco. Many small mills and smelting works were built. Such smelters were located at Copper Mountain, Walker, Blue Dick, Briggs, Whipsaw, Mayer, and other places, but most of them were failures. The earliest successful plant was the one near Mayer, built in 1901 by the Val Verde Copper Co. The mills were more productive; pan amalgamation and plate amalgamation were tried in succession and were later followed by the cyanide and flotation process. The larger part of the gold and silver produced in the earlier years was derived from local mills.

About 1885 many of the rich oxidized ore bodies were worked out and leaner ore was found in depth. However, the activity continued, with many failures, to about 1905 . Since that time a gradual decline has taken place in the Bradshaw Mountains, while the Jerome district has risen to predominance by the development of the United Verde mine, which may be said to date from 1894. Spurred by the United Verde discovery a great and more or less continuous activity has been shown near Jerome in attempts to find similar large copper deposits. Most of these attempts have been failures, but in 1914 the search was rewarded by the discovery of the phenomenally rich ore bodies now worked in the United Verde Extension mine. At present Jerome is the center of the mining activity in the region, completely overshadowing the older Bradshaw area.

In 1922, when this examination was undertaken, the Bradshaw area showed evidence of decline and neglect. Many of the old roads, in good condition in 1900, are now impassable, and the trails, overgrown by brush, can hardly be followed. The population has decreased, and many properties are abandoned, cattle seeking shelter 
in the old mill buildings and the wind rattling with dismal effect in the sheet-iron roofs.

At Jerome two first-class copper mines are producing heavily, with a considerable output of gold and silver as by-products. The ores from these mines are reduced in two smelters near Clarkdale, in the Verde Valley, below the mines. (See pl. 12, A.) The rest of the Black Hills is making only a negligible production, though containing many small deposits.

The southern, western, and northern parts of the Jerome quadrangle are unimportant so far as mining is concerned.

In the Bradshaw Mountains quadrangle most of the mines we idle, and only one small mill was in operation in 1922.

The mainstay of the region is the Humboldt smelter, a few miles. north of Mayer. This plant had been closed during the war, but the furnaces were started again in July, 1922, by the Southwest Metals Co., successors to the Consolidated Arizona Smelting Co. The principal source of ore for this smelter is the Blue Bell mine, which with the De Soto and Binghampton mines has in later years furnished a large amount of pyritic copper ore. Such of the smaller mines as are in operation generally ship their ore to this smelter. Most of the shipments are small, but in the aggregate they form a considerable quantity..

Parcels of rich oxidized ore are still coming in from many districts, but the fact is, and it might as well be faced, that the primary, sulphide ores are generally of a grade dangerously close to the lower limit. This statement applies quite generally to the Bradshaw Mountains but of course is not universally true. The Sheldon mine, at Walker, for instance, finds it profitable to ship its sulphide ore to Humboldt. The very unfavorable conditions of wartime closed many mines that may well be reopened with profit. Perhaps this would be true of some of the mines on veins in the Hassayampa district near the Senator mine, some that have yielded well in the vicinity of Chaparral and McCabe, and perhaps some in the Crown King district. Nevertheless, ores containing $\$ 5$ to $\$ 10$ to the ton are much more plentiful than those of higher grade. This grade, of course, is prohibitively low for shipment to a smelter, and progress should be directed to the construction of proper mills able to concentrate cheaply. Free gold will have to be amalgamated, but in the deeper ores the proportion of this material is usually small.

The war, the scarcity of miners, and the high prices of supplies naturally account to some extent for the present depressed state of the industry. Better conditions may be hoped for, and with careful and economical work a number of deposits may be expected to prove remunerative. It would be unfortunate if the Humboldt 
smelter should find the available ore supplies insufficient to justify continued operation. In that event ores and concentrates would be shipped to Douglas, Ariz., or to El Paso, Tex. A branch road from Prescott to Humboldt, Mayer, and Crown King now serves the central part of the region. For some time the service from Mayer to Crown King was practically suspended.

\section{PRODUCTION}

The two quadrangles here described contain the greater part of the workable deposits in Yavapai County. In the adjacent Congress quadrangle, to the west, also in this county, there are a considerable number of mines, though most of them are now closed. Among these are the Octave and Congress gold mines, which about a decade or two ago were notable producers. Of late years the production of Yavapai County is not far from representing that of the Jerome and Bradshaw Mountains quadrangles. This yield is annually recorded by the United States Bureau of Mines through V. C. Heikes, of Salt Lake City, who is in charge of the statistics for Arizona and certain other Western States. The figures of the mine production are recorded below. For the earlier years no separate record of the several metals was kept, and the figures given are taken from the reports of the Director of the Mint. They are incomplete and often omit the gold and silver produced from lead and copper bullion. Since 1894 the production from the United Verde mine and since 1915 that from the United Verde Extension have overshadowed the production from the Bradshaw Mountains almost completely. In the Jerome quadrangle practically the whole production is derived from these two mines, but that from the Bradshaw Mountains quadrangle is obtained from about a hundred small mines.

Gold and silver produced in Yavapai County, Ariz., 1883-1901

[From reports of the Director of the Mint]

\begin{tabular}{|c|c|c|c|c|c|}
\hline & Gold & Silver & & Gold & Silver \\
\hline $\begin{array}{l}1883 \\
1884 \\
1885 \\
1886 \\
1888\end{array} 1889$ & \begin{tabular}{r}
$\$ 25,000$ \\
40,000 \\
\hdashline 98,088 \\
84,264 \\
193,951 \\
461,704 \\
496,021 \\
383,328 \\
391,801
\end{tabular} & $\begin{array}{r}\$ 800,000 \\
940,000 \\
18,871 \\
339,638 \\
222,176 \\
162,761 \\
192,494 \\
232,596 \\
202,365\end{array}$ & $\begin{array}{l}1893 \\
1894 \\
1895 \\
18967 \\
1898 \\
1899{ }^{\circ} \\
1900 \\
1901\end{array}$ & $\begin{array}{r}\$ 339,755 \\
867,840 \\
1,258,831 \\
1,579,659 \\
1,229,540 \\
1,070,281 \\
1,800,000\end{array}$ & $\begin{array}{l}\text { o } \$ 344,739 \\
\text { b } 256,931 \\
\text { o } 322,033 \\
\text { b } 131,389 \\
\text { o } 565,701 \\
\text { b } 263,430 \\
500,000\end{array}$ \\
\hline
\end{tabular}

a No record.

- Fine ounces. 
Gold, silver, copper, lead, and zinc produced in Yavapai County, Ariz., 1902-1924

[From V. C. Heikes, in U. S. Geological Survey Mineral Resources]

\begin{tabular}{|c|c|c|c|c|c|c|c|c|}
\hline Year & $\begin{array}{l}\text { Number } \\
\text { of pro- } \\
\text { ducers }\end{array}$ & Ore & Gold & Silver & Copper & Lead & $\begin{array}{l}\text { Recover- } \\
\text { able zinc }\end{array}$ & $\begin{array}{l}\text { Total } \\
\text { value }\end{array}$ \\
\hline & & Short tons & & Fine ounces & Pounds & Pounds & Pounds & \\
\hline $\begin{array}{l}1902 . \\
1903 .\end{array}$ & $\begin{array}{l}39 \\
31\end{array}$ & $\begin{array}{l}264,180 \\
301,770\end{array}$ & $\begin{array}{r}\$ 1,693,514 \\
1,609,158\end{array}$ & $\begin{array}{l}466,874 \\
602,087\end{array}$ & $\begin{array}{l}19,554,914 \\
23,999,628\end{array}$ & $\begin{array}{l}752,076 \\
841,404\end{array}$ & . & $\begin{array}{r}\$ 4,353,570 \\
5,254,021\end{array}$ \\
\hline 1904 & 34 & 439,622 & $2,013,747$ & 953,622 & $30,826,286$ & 497,905 & 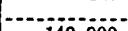 & $6,434,764$ \\
\hline $\begin{array}{l}1905 \\
1900\end{array}$ & $\begin{array}{l}39 \\
46\end{array}$ & $\begin{array}{l}364,6 \\
396.7\end{array}$ & $\begin{array}{l}1,391,070 \\
1,256,623\end{array}$ & $\begin{array}{l}786,7 \\
708,4\end{array}$ & $\begin{array}{r}34,279,734 \\
42,080,740\end{array}$ & $\begin{array}{l}697,806 \\
729,787\end{array}$ & 140,000 & $\begin{array}{l}7,254,936 \\
9,894,458\end{array}$ \\
\hline 007 & 117 & 375,398 & $1,144,102$ & 647,488 & $35,734,416$ & 521,307 & 140,786 & $8,754,263$ \\
\hline & 79 & 314,1 & $1,116,793$ & 602,6 & $36,248,440$ & 362,334 & $2+4,100$ & $6,236,207$ \\
\hline & 56 & 323,489 & 952,243 & 578,5 & $37,125,964$ & 409,890 & & $6,097,105$ \\
\hline & 104 & 417,3 & 881,9 & 669, & 40,824, & 264,911 & & $6,456,184$ \\
\hline & 109 & 245 & & 764,7 & $36,103,6$ & 318,089 & 47,165 & $5,624,956$ \\
\hline & & & & 748 & $34,043,0$ & 481,827 & 292,705 & $6,602,032$ \\
\hline & 105 & 447, & 517,2 & 854,0 & $38,719,9$ & 242,369 & 211,533 & $7,057,167$ \\
\hline & 100 & 459 & 557,0 & 786, & 34,0 & 169, & & $5,528,565$ \\
\hline & 107 & 614,8 & 791,8 & $1,343,3$ & $59,229,1$ & 161,750 & 48,580 & $11,851,688$ \\
\hline & 95 & 967,5 & $1,035,351$ & $1,735,302$ & $109,525,718$ & 265,023 & 583,741 & $28,217,015$ \\
\hline & 88 & $1,176,6$ & $1,023,4$ & $2,207,5$ & $159,612,1$ & 686,874 & & $46,572,677$ \\
\hline & 93 & $1,301,8$ & $1,117,701$ & $2,502,968$ & 148, & 348,389 & & $40,451,953$ \\
\hline & 79 & 700 & 614,968 & $1,252,894$ & $80,227,5$ & 237,605 & 1,71 & 17,078 , \\
\hline & 73 & $1,038,2$ & 659,5 & $1,555,075$ & $114,937,080$ & 238,296 & 1,457 , & $23,640,101$ \\
\hline & 51 & 191,964 & 112,984 & 383,193 & $26,576,298$ & 172,150 & & $3,932,266$ \\
\hline & 83 & 601,3 & 464,101 & 949,331 & $76,607,5$ & 82,199 & & $11,759,966$ \\
\hline & 73 & $1,594,2$ & $1,902,3$ & $2,879,763$ & $147,718,4$ & 226,953 & & $25,994,289$ \\
\hline & 43 & $1,407,479$ & $1,239,157$ & $2,269,788$ & $143,348,230$ & 118,041 & & $21,547,976$ \\
\hline
\end{tabular}

- Large companies closed owing to depression, but now operating.

The whole production of the two quadrangles to the end of 1923 probably approaches $\$ 300,000,000$, including the total value of gold, silver, copper, lead, and zinc. No other metals are produced in noteworthy amounts. Jaggar and Palache ${ }^{2}$ estimate the total production of gold and silver in the Bradshaw Mountains quadrangle to the end of 1901 at $\$ 9,500,000$, which I am convinced is too low. The output scarcely reaches $\$ 1,000,000$ in any one year and in many years it falls very much below that figure. From the approximately known production of 23 mines in this quadrangle $I$ have obtained the sum of $\$ 14,000,000$, and I believe that the total gold and silver from 1875 to the end of 1923 , or almost 50 years, is not less than $\$ 18,000,000$, which would represent an average annual output of $\$ 360,000$. Of course the production has fluctuated greatly and some placer gold was produced before 1875 .

\section{MINING DISTRICTS NEAR AREA HERE DESCRIBED}

Yavapai County includes a number of mining districts not described in this report, which is confined to the Bradshaw Mountains and Jerome quadrangles. East of these quadrangles are the Squaw Peak district, 10 miles south of Camp Verde, and the Copper Creek and Squaw Creek districts, east of the Black Canyon district, none of which have made any notable production. On the southwest side

2 U. S. Geol. Survey Geol. Atlas, Bradshaw Mountains folio (No. 126), 1905. 
of the Bradshaw Mountains quadrangle are the Red Picacho, White Picacho, Blue Tank, and Black Rock districts. The Black Rock district includes a number of gold and silver mines, some of which have been more or less productive. The Walnut Grove district, a short distance west of Copperopolis, includes a great number of small properties and some placer ground. The Copper Basin district, west of Prescott, has a fairly large output of copper and some molybdenum to its credit. The Weaver and Martinez districts, still farther west contain, respectively, the Octave and Congress mines, which have been large producers from gold quartz veins but are now idle. In the extreme western part of the county lies the Harcuvar district, and in the northwest corner the Ochocomo and Eureka districts. The Eureka contains the Bagdad mine, which has a large copper deposit far distant from rail communication and is not extensively operated.

\section{GENERAL GEOLOGY}

\section{PHYSIOGRAPHY}

The area here described is approximately 70 miles long from north to south and 28 miles wide and lies between parallels $34^{\circ}$ and $35^{\circ}$ and meridians $112^{\circ}$ and $112^{\circ} 30^{\prime}$. The altitude ranges from 1,900 feet at the most southerly point of Agua Fria River to 7,971 feet on the summit of Mount Union, in the Bradshaw Mountains.

According to Ransome, Arizona may be divided into three physiographic provinces trending northwest-the plateau region of flatlying Paleozoic sediments; the mountain region, an area of irregular mountain masses, lying southwest of the plateau; and the desert region of short ranges trending north or northwest and separated by wide stretches of desert plains. The limit between plateau and mountain is sharply marked by recessed cliffs of horizontal Paleozoic beds, which are prominent in the landscape and are known as "the breaks." From northwest to southeast there are in succession many such breaks, beginning on Colorado River with the Grand Wash Cliffs, which are succeeded in turn by Music Mountain, by the Verde breaks, in the area here discussed, and by Mogollon Mesa, farther southeast.

The area considered in this paper extends acress the Verde breaks and includes a part of the mountain region. It presents many physiographic problems of the first magnitude, which can only be briefly touched upon.

We have to deal with comparatively few units, already referred to on page 1. The flat-lying Paleozoic beds occupy the larger part of the northeastern section of the Jerome quadrangle. They rest 
on the peneplaned surface of the pre-Cambrian, and their thickness, from the basal beds (Cambrian) to the top of the Coconino sandstone (Permian), amounts to 2,500 feet. Gradually thinned out by erosion, the southern outliers rest on pre-Cambrian granite in the south end of the Black Hills.

Strong fault lines of recent date mark the eastern slope of the Black Hills-in fact, the Verde fault, with a throw of at least 1,700 feet-can be traced continuously across the whole northeastern part of the Jerome quadrangle far into the plateau province. It is scarcely to be doubted that other older faults outlined the western slope of the Black Hills and all four sides of the Bradshaw Mountains. The plateau province is thus adjoined by a series of preCambrian fault blocks, and few areas offer as good an opportunity to investigate the relation of mountain to plateau.

The top of the plateau attains 6,000 feet in the northeast corner of the Jerome quadrangle. The mountain region includes two main masses-the Black Hills and the Bradshaw Mountains. The Black Hills consist of an irregular orographic block capped in pari by flat Paleozoic beds and Tertiary lavas, trending north-northwest for about 20 miles and 8 to 12 miles wide. This block is doubtless outlined by faulting and merges on the north into the flat plateau rocks. On the east it is delimited by the deep Verde Valley, filled by late Tertiary deposits; on the west by the higher plains of Lonesome Valley.

South of this range rises the irregular block of the Bradshaw Mountains, occupying about the whole of the Bradshaw Mouritains quadrangle. (See pl. 3, B.) Essentially these mountains are a series of broad ridges trending north or north-northwest and dissected by a vast number of valleys and gulches that generally drain southward. At the south end of the quadrangle the ridges dip below the lava flows of the lower Agua Fria River, and the topography of the low-lying pre-Cambrian rocks becomes an intricately dissected landscape of irregular ridges and sharp points or "picachos."

The drainage is southward toward Gila River, by Hassayampa, Agua Fria, and Verde Rivers. The Hassayampa drains the western edge of the Bradshaw Mountains quadrangle, and the Agua Fria the central part. Stream capture effected by the active southward drainage is much in evidence. Thus the Agua Fria has captured the drainage of Lonesome Valley, and the Verde through a sharply incised canyon has captured streams draining much of the plateau region in the northern part of the Jerome quadrangle.

The Tertiary lavas (see pl. $3, A$ ) occupy scattered areas on the plateau in the north and also much of the eastern half of the 


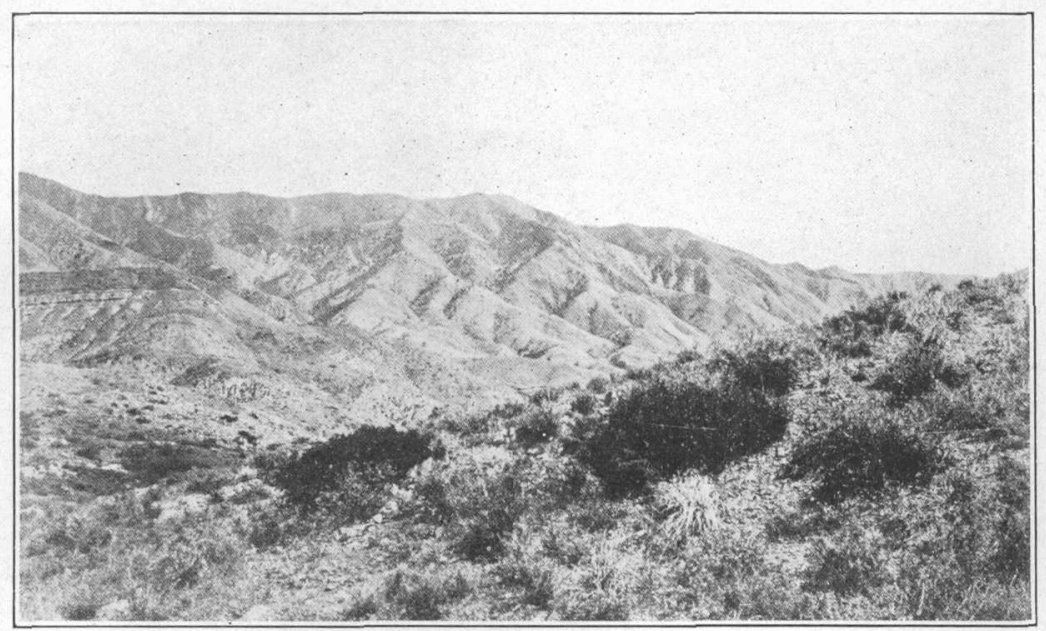

A. SILVER MOUNTAIN, LOOKING EAST FROM HILL NEAR COPPEROPOLIS

Characteristic schist topography. Tertiary volcanic rocks at left, horizontally bedded

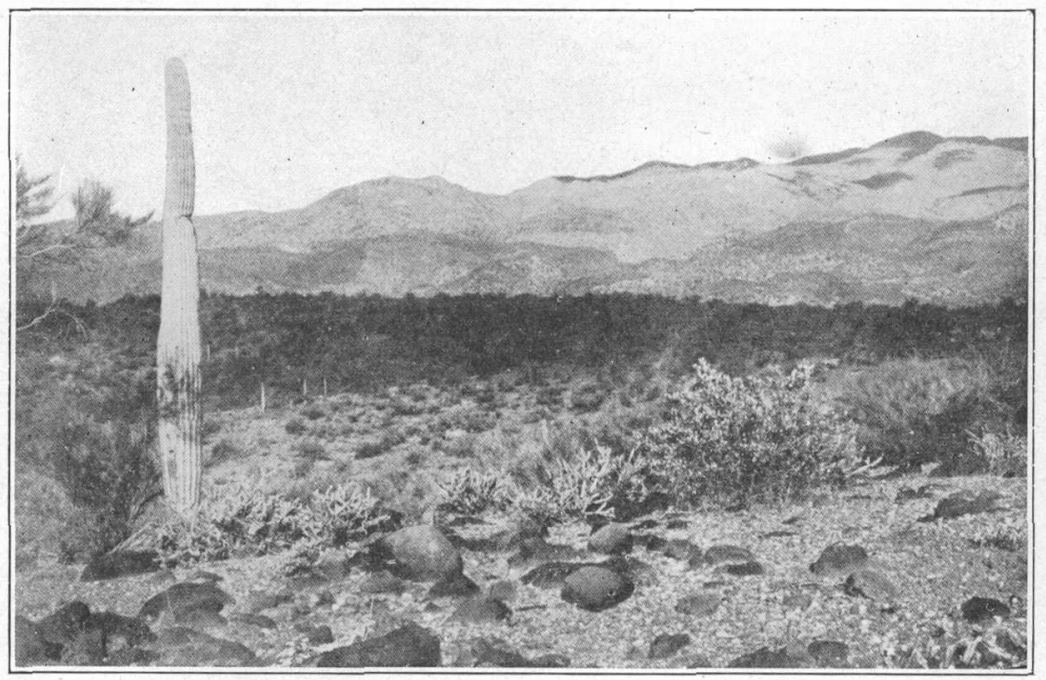

B. BRADSHAW MOUNTAINS, LOOKING NORTHEAST FROM POINT NEAR GODDARD'S RANCH

Mountains composed of Bradshaw granite; basaltic agglomerate in the foreground 
Bradshaw Mountains, which drops off sharply from the pre-Cambrian ridges of the western half. In the latter region they form a dissected plateau with a surface altitude of about 4,000 feet. The advent of the late Tertiary lava flows modified the drainage to a considerable extent. Thus probably the whole of the lower Agua Fria was laid out along a new course over the flows in the eastern part of the Bradshaw Mountains quadrangle. But in the main the drainage far antedates the flows.

\section{PALEOZOIC SEDIMENTS}

The series of flat Paleozoic sandstones and limestones as exposed in the northeast corner of the Jerome quadrangle has a thickness of about 2,500 feet. The approximate succession as recorded by Ransome, ${ }^{3}$ with changes in age assignment to accord with present classification, is as follows:

\section{Section of Paleozoic formations in Jerome quadrangle}

$\begin{array}{lr}\text { Coconino sandstone (Permian) } & \text { Feet } \\ \text { Supai formation (Permian (?) and Pennsylvanian) } & 500 \pm \\ \text { Redwall limestone (?) (Mississippian) } & 1,000 \pm \\ \text { Limestones (Devonian, at least in part) } & \\ \text { Tapeats ("Tonto") sandstone (Cambrian) } & \\ \text { Great unconformity. } & \\ \text { Pre-Cambrian. } & \mathbf{2 , 3 3 0}\end{array}$

These beds are in full view from points near Jerome on the upper slopes of the Black Hills, across the Verde Valley, and present a wonderful geologic panorama. The Tapeats sandstone forms a narrow brown band rarely to be observed from a distance. The Devonian beds are pale yellow and gray; above them rests the white Redwall limestone, and this in turn is covered by the Supai sandstones, which gleam brilliantly red when illumined by the rays of the setting sun. The level top of the plateau in the extreme corner of the quadrangle is surmounted by a narrow dark fringe of the pine forests, and the slopes below are bare and sculptured by erosion into a series of salients and recesses, with battlements and towers alternating with gentler slopes.

This section is materially thinner than those obtained along the Grand Canyon; at Tovar the strata measure 3,600 feet up to the top of the Coconino. The Devonian, however, which is represented in the Grand Canyon by 100 feet or less of Temple Butte limestone,

\footnotetext{
${ }^{8}$ Kansome, F. L., Some Paleozoic sections in Arizona and their correlation: U. S. Geol. Survey Prof. Paper 98, pp. 159-162, pl. 25, 1916.

4 The basal quartzite at Jerome has not been definitely identified as the Tapeats (Cambrian) formation.
} 
appears to be thicker here, although some of the 500 feet of limestone so classified may not be of Devonian age. Both sections agree in that they are relatively thin compared with the 30,000 feet of Paleozoic beds in eastern Nevada. Furthermore, both sections in Arizona, though apparently conformable, include several unconformities, so that there are many gaps in the succession.

The region here described is part of a large positive element of the crust, which in general has tended to rise. It is not a part of any geosyncline.

\section{PRE-PALEOZOIC PENEPLAIN}

The Paleozoic beds were laid down on a surface peneplaned by long erosion. As the sea advanced it destroyed any surface débris that might have accumulated, and a basal sandstone or fine conglomerate was laid down, first known as the "Tonto" sandstone and determined as Cambrian in several sections. Along the Grand Canyon these beds are several hundred feet thick and are overlain by 200 or 300 feet of Cambrian shale. In the Jerome section the "Tonto" (now called Tapeats) sandstone averages only 50 feet and, indeed, in places thins out almost entirely. It is overlain by a slight thickness of shale, which may represent the Bright Angel shale of the Grand Canyon section, and above this is the so-called Devonian limestone. The age of the sandstone at Jerome has not been proved, but it looks like the Tapeats sandstone of the Grand Canyon area, which contains Cambrian fossils. Just north of Lonesome Valley the Tapeats (?) is again exposed, and here it appears to be somewhat thicker than at Jerome.

We may assume, then, that the Cambrian sea advanced southward, transgressing over the pre-Cambrian peneplain, which gradually rose in this direction. Whether the Paleozoic beds up to the top of the Coconino sandstone covered the whole of these two quadrangles is a question open to discussion. The lowest Supai red beds form the uppermost part of the Paleozoic section in the Black Hills and directly underlie the Tertiary basalt.

\section{RELATION OF THE PLATEAU PROVINCE TO THE MOUNTAIN REGION}

- The pre-Cambrian peneplain now lies at an altitude of 3,400 feet in the Bright Angel and Vishnu quadrangles of the Grand Canyon region. In the Shinumo quadrangle, ${ }^{5}$ adjoining the Bright Angel on the west, the same horizon lies at 2,400 to 3,400 feet, the contact being very irregular in spots, though comparatively level as a whole.

\footnotetext{
5 Noble, L. F., The Shinumo quadrangle, Grand Canyon district, Ariz.: U. S. Geol. Survey Bull. 549, 1914.
} 
Southwest of Ash Fork, on the main line of the Atchison, Topeka \& Santa $\mathrm{Fe}$ Railway, we find the same peneplain at an altitude of 4,800 feet. This is about 65 miles south of the Grand Canyon. About 25 miles farther south the base of the Tapeats crops out along Verde River at altitudes of 4,400, 4,200, 3,700, and 3,600 feet; the lowest figure was obtained at Packard's ranch, 6 miles north of Clarkdale. About 8 miles farther south, at the north edge of Lonesome Valley, the same basal plane lies considerably higher, at 5,200 to 5,300 feet. Still farther south, on the west side of the Black Hills, we find it at 6,000 to 6,400 feet, and at the south end of the hills, near Cherry, at 5,600 feet. On the east side of the Black Hills the Tapeats rests on the pre-Cambrian at 6,000 feet, but just east of the Verde fault, as shown in the Edith shaft of the United Verde Extension mine, it is thrown down to 4,230 feet.

In the Verde Valley, at the smelters of Clarkdale and Clemenceau, borings through the white lake beds of the Verde formation have encountered the pre-Cambrian at a depth of 1,200 feet, ${ }^{6}$ or an altitude of 2,000 feet. Evidently there is here a deep depression in the pre-Cambrian surface, but it may possibly be due to more intense erosion of the pre-Cambrian beds in this particular area rather than to faulting.

To sum up, it appears that the position of the top of the preCambrian is abnormally high in the Black Hills and abnorrnally low in the Verde Valley.

It would seem at first glance that the cliffs that mark the edge of the plateau province and stand up above the surrounding country indicate an uplift of the plateau. This is not so, however. Along the Grand Wash Cliffs runs a deep fault along which the country to the east has been relatively thrown down, and points in the Kingman and Hualpai ranges, to the southwest, stand high above the Tapeats horizon. W. T. Lee ${ }^{7}$ interprets the structure in this area, southwest of Music Mountain, to the effect that the southwest side has been broken up into eastward-tilted fault blocks, from which an enormous erosion has removed the Paleozoic blocks. According to Ransome, ${ }^{8}$

South of Ash Fork the continuity of the plateau escarpment is interrupted by flows of basalt that poured down from the platean to the vallev of the Verde, forming a slope that has been utilized by the Santa Fe, Prescott \& Phoenix Railway between Ash Fork and Jerome Junction.

East of this slope the escarpment again begins, forming the "Verde breaks," already referred to as visible from Jerome.

${ }^{\theta}$ Finlay, J. R., The Jerome district of Arizona : Eng. and Min. Jour., vol. 108, Sept. 28 and Oct. 5, 1918.

${ }^{7}$ Lee, W. T., Geologic reconnaissance of a part of western Arizona: U. S. Geol. Survey Bull. 352, 1908.

${ }^{8}$ Ransome, F. L., op. cit., p. 134. 
All this is interpreted as follows: Between the Grand Canyon and the upper Verde Valley the pre-Cambrian peneplain is fairly uniform, ranging from 3,600 to 4,800 feet in altitude over a distance of 100 miles. The Black Hills form an uplifted block, perhaps slightly tilted, separated by an obscure fault line from Lonesome Valley and by a well-marked fault, the Verde fault, from the depressed block on the west side of the Verde Valley. The Verde fault is later than the basalt and the Verde beds and is therefore of very late Tertiary or post-Tertiary age. It trends north-northwest and breaks into the plateau country where it crosses the upper canyon of the Verde. The downthrow amounts to 1,700 feet, and the fault has several branches, according to the mapping by Jenkins and Reber. Near the base of the slope in the vicinity of Clarkdale there is probably another parallel fault of unknown magnitude. In the block or "horst" of the Black Hills the base of the 'Tapeats lies abnormally high-that is, from 5,300 to 6.400 feet above the sea. The conclusion is that the block of the Black Hills has been lifted or tilted, and at the same time there has been a downward movement of a block underlying the Verde Valley. The effect is a relative depression of the edge of the plateau.

It is likely that there are other block faults, probably of earlier formation. Almost certainly one runs from north to south dividing the lava-flooded eastern part of the Bradshaw Mountains quadrangle from the higher mountainous region of the western half. The highest altitudes in this quadrangle lie between 7,000 and 8,000 feet. It is clear that if Paleozoic rocks rested on top. of these highlands they would have attained a height at least equivalent to a present altitude of 10,000 feet. On any supposition the mountain province has risen relatively to the edge of the plateau. Actually, I think, the Paleozoic beds thinned out very much toward the south, and the Bradshaw highlands may never have been covered.

Supporting evidence for this suggestion is found in the following considerations: There are in the Bradshaw Mountains several stocks of granodiorite, some of them several miles in diameter, which are believed to be of Mesozoic age. Their present exposures reach an altitude of 7,500 feet and could hardly have been less than 3,000 feet. below the Mesozoic surface. That surface may have been formed by flat Paleozoic beds or by the partly eroded pre-Cambrian peneplain. Furthermore, the Bradshaw Mountains are intersected by one of the most remarkable systems of dikes in the world, which reach at least 7,500 feet in altitude and which must have penetrated to the surface and produced volcanic flows of vast extent. Of these flows there are now no traces. This system of rhyolite dikes is genetically con- 
nected with veins of epithermal to mesothermal type, most probably formed at depths not less than 3,000 feet.

All in all, I see no escape from the conclusion that the present exposures in the Bradshaw Mountains are about 3,000 feet or more below the pre-Cambrian erosion surface and that at the end of Paleozoic time these mountains projected as a vast dome above the edges of the transgressing sediments.

The only alternative would be to assume strong faulting or deformation between the Black Hills and the Bradshaw Mountains, which may have changed their relative elevations. Some such faulting may have occurred but is probably not sufficient to explain the absence of Paleozoic strata in the Bradshaw Mountains.

\section{POST-PALEOZOIC EROSION}

An enormous erosion intervened in the northern part of the mountain province between the deposition of the Kaibab limestone and the next notable event-the outpouring of the Tertiary basalt and allied rocks. The basalt rests on the Supai formation only in the northeast corner of the Jerome quadrangle and the northern part of the Black Hills. Elsewhere it rests mostly on the Devonian limestone or the Tapeats sandstone, or, as in parts of the Black Hills and over the whole of the Bradshaw Mountains, on the preCambrian rocks.

The second period of erosion was postbasaltic and post-Tertiary. It also was of tremendous extent. It included the excavation of the main Verde Valley, both sides of the uplifted fault block of the Black Hills, and the whole upper Verde River above Packard's ranch and the trenching of the Bradshaw Mountains by deep canyons, which are best measured around Bigbug Mesa. It included the cutting of the new canyon of the Agua Fria and its capture of Lonesome Valley; also the capture by Verde River of its whole upper drainage system in the northern part of the Jerome quadrangle. Rarely can such vast physiographic changes be observed.

\section{VOLCANIC FLOWS}

Though the Tertiary flows were well scattered over the whole area (see pls. 1 and 2), they were not of great thickness, probably nowhere more than 700 or 800 feet, and as a rule much thinner. In the Jerome quadrangle they consist mainly of basalt, but in the Bradshaw Mountains there are also some andesite and rhyolite and much mixed volcanic agglomerate. Feeders such as necks and dikes are to be seen in many places, but no volcanoes or craters remain. The age of the flows, according to Robinson's determination in the San Franciscan field, is believed to be Pliocene. 
The main flows descended toward Lonesome Valley and the Black Hills from the plateau in the vicinity of Flagstaff and Bill Williams Mountain. Another vast flow covered the depression in the east half of the Bradshaw Mountains quadrangle and no doubt followed the Tertiary equivalent of Agua Fria River. Still another line of flows may be observed along the western margin of the same quadrangle and may be considered as filling a branch of the Tertiary equivalent of the Hassayampa.

\section{VERDE FORIIATION}

The main Verde Valley is now filled to a depth of at least 1,500 feet by the white lake beds which Reber ${ }^{9}$ and Jenkins ${ }^{10}$ have called the Verde formation. The valley from Packard's ranch down to a point beyond the limits of the Jerome quadrangle may have been outlined by the pre-basalt erosion, but in late Tertiary or Quaternary time dislocations parallel to the edge of the plateau caused it to sink like a deep graben. The whole of Verde River is therefore a comparatively late development. The lake beds rest on the faulted blocks. On Plate 1 the Verde formation is classified as Pliocene, but it may be of Pleistocene age.

\section{IATEST FORMATIONS}

The most recent formations include certain low river terraces and alluvial deposits in the Verde and Lonesome valleys.

\section{PRE-CAMBRIAN ROCKS}

\section{GENERAL FEATURES}

The pre-Cambrian rocks occupy large areas in the southwestern half of Arizona. They emerge from under the flat Paleozoic rocks of the plateau province along the diagonal line of "the breaks," as is well illustrated in the northeastern part of the Jerome quadrangle. South of this line they appear in nearly every mountain range from Clifton, Globe, and Bisbee to Kingman, Yuma, and Parker. Toward the north these rocks are not exposed for long distances except where they are laid bare in the narrow trench of the canyon of Colorado River.

W. P. Blake, ${ }^{11}$ when Territorial geologist of Arizona, first described them in 1883. Since then they have been investigated by

- Reber, L. E., Jr., Geology and ore deposits of the Jerome district : Am. Inst. Min. and Met. Eng. Trans., vol. 66, pp. 8-11, 1922. Adopts Jenkins's proposed namre Verde formation.

10 Jenkins, O. P., Verde River lake beds near Clarkdale, Ariz.: Am. Jour. Sci., 5th ser., vol. 5, pp. 65-81, 1923.

11 Blake, W. P., Geology of the Silver King mine : Eng. and Min. Jour., vol. 35, pp. 238239,1883 ; also in the reports of the Governor of Arizona, 1896-1899, particularly in report for 1899 , p. 139 . 
many geologists, particularly by Jaggar and Palache ${ }^{12}$ in the Bradshaw Mountains; by Ransome ${ }^{13}$ at Ray, Miami, and Bisbee and in the Mazatzal Mountains; by Lindgren ${ }^{14}$ at Clifton; by Schrader ${ }^{15}$ and Bancroft ${ }^{16}$ in the western part of the State adjoining Colorado River; by Bryan ${ }^{17}$ and Ross ${ }^{18}$ in southwestern Arizona.

The pre-Cambrian rocks of Arizona may be divided as follows:

Grand Canyon series: Algonkian, probably of the same age as the Belt series of Montana and Idaho. Bedded sediments. Not definitely recognized except in Grand Canyon.

Mazatzal and other quartzites: Probably late pre-Cambrian.

Dike intrusions: Diorite porphyry (Jerome), diabase porphyry (Blue Bell mine). Latest pre-Cambrian. Not schistose.

Granites: Large widely distributed masses of intrusive normal granite with more or less pegmatite. In the region here described it is called the Bradshaw granite. In places gneissoid.

Diorite, "quartz porphyry," and monzonite: Smaller masses intrusive in schist and probably a facies of the granite.

Schists: Highly compressed, intruded by the granites. They are known as the Pinal schist at Globe, Ray, Clifton, and Bisbee, where they are predominantly of sedimentary origin. Near granites they are metamorphosed and may contain andalusite, sillimanite, and staurolite. They are known as the Yavapai schist in the Bradshaw Mountains quadrangle, where they are in large part also of sedimentary origin. They are known as the Vishnu schist in the Grand Canyon, where they unconformably underlie the Grand Canyon series. There is no reason to doubt that in the main these schists represent the same formation. The name. "Arizonian schist" would, in my opinion, suit all these occurrences very well.

The schists are the earliest known pre-Cambrian rocks, though the occurrence in them of conglomerates made up of granite; quartzite, and other rocks would indicate that there existed an older series from which they were derived. At present all the granite with which they are in contact is intrusive.

The pre-Cambrian also includes certain flat-bedded sediments, consisting of slate, quartzite, limestone, and amphibolite, found near Parker on Colorado River and in the Harcuvar Range. They rest on older gneissoid and granitic rocks, and their correlation is

12 Jaggar, T. A., Jr., and Palache, Charles, U. S. Geol. Survey Geol. Atlas, Bradshaw Mountains folio (No. 126), 1905.

${ }^{13}$ Ransome, F. L., Geology of the Globe copper district: U. S. Geol. Survey Prof. Paper 12, 1903; Geology and ore deposits of the Bisbee quadrangle, Ariz.: Prof. Paper 21, 1904 ; The copper deposits of Ray and Miami, Ariz.: Prof. Paper 115, 1919 ; Quicksilver deposits of the Mazatzal Range, Ariz. : Bull. 620, pp. 111-128, 1916.

14 Lindgren, Waldemar, The copper deposits of the Clifton-Morencl district, Ariz.: U. S. Geol. Survey Prof. Paper 43, 1905.

${ }_{15}$ Schrader, F. C., Mineral deposits of the Cerbat Range, Black Mountains, and Grand Wash Cliffs, Mohave County, Ariz.: U. S. Geol. Survey Bull. 397, 1909.

${ }^{16}$ Bancroft, Howland, Reconnaissance of the ore deposits in northern Yuma County, ArIz. : U. S. Geol. Survey Bull. 451, 1911.

${ }^{17}$ Bryan, KIrk, Erosion and sedimentation in the Papago country, Ariz.: U. S. Geol. Survey Bull. 730, pp. 19-90, 1922.

${ }^{18}$ Ross, C. P., Geology of the lower Gila region, Ariz. ; U. S. Geol. Survey Prof. Paper 129, pp. 183-197, 1922. 
not known. They are not identical with the Yavapai schist nor with the Grand Canyon series, and they are not intruded by granite. In this region the underlying granite is much more gneissoid than elsewhere. Whether or not it is of the age of the Bradshaw granite it uncertain.

\section{DIKE INTRUSIONS}

Dikes intruded at just about the end of the pre-Cambrian period of mineralization and probably of the age of the Bradshaw granite have been found in several places but are of small extent. At Jerome they are narrow, strike east, and seem to be related to diorite porphyry. They are greatly decomposed and cut across the diorite, schist, and pyritic deposits. The persistent dike that cuts across the Blue Bell mine is a panidiomorphic dike rock with labradorite, augite, brown hornblende, and a little sericite and chlorite. Possibly it is later than the pre-Cambrian.

\section{BRADSHAW GRANITE}

The typical rock of the Bradshaw granite is white, of coarse to medium grain, and forms large rounded outcrops of yellowish-gray color. It is uniform over large areas and is rarely gneissoid, though evidence of strain is commonly observed in thin sections. In color it differs from the pre-Cambrian granite at other places-that at Clifton, for instance, which is dark reddish. It everywhere contains quartz, orthoclase, and microcline, and in places perthite, with some plagioclase, which may be zoned, and which is generally an oligoclase-albite. The dark constituents are scarce and consist of biotite and rare hornblende. The accessories are apatite and zircon, but there is no titanite. A type locality is in the vicinity of Prescott. Reddish varieties occur in places, but differ little in composition from the normal type. Here and there the rock is porphyritic, having larger microcline crystals. Jaggar and Palache, in the folio already cited, give a partial analysis of granite from Crooks Canyon, as follows: Silica, 74.62 per cent; lime, 1.06; potash, 3.90 ; soda, 3.99. They say: "Pegmatitic facies are extremely abundant in the great southern stock, particularly along the eastern contact, where extensive areas, practically all of pegmatite, are found." The vicinity of the Tiptop mine well illustrates this statement. Many of the pegmatite dikes contain tourmaline.

The granite in the southern part of the Jerome quadrangle is normal, but in Lonesome Valley, in the Coyote Hills, and also at the north side of the same valley there are many smaller masses of medium-grained granite poor in mica, some of it pegmatitic and of a yellowish to reddish color. In many places these masses are mixed with included masses of schist. 
'The smaller masses of diorite in the Bradshaw Mountains quadrangle are fully described by Jaggar and Palache. They show a very hard and dark medium-grained rock, which may be regarded as a facies of the granite or at least a closely allied intrusive. The smaller masses of diorite at Jerome and the dikes at the Shea mine, :south of Jerome, and the Yaeger mine, on the west side of the Black Hills, are similar and are more fully described on pages 57, 92, and 98 .

The gneissoid monzonite of Battle Flat is also fully described in Folio 126 and is probably of about the same age.

YAVAPAI SCHIST

\section{BRADSHAW MOUNTAINS QUADRANGLE}

The schists, which occupy large areas in the Bradshaw Mountains quadrangle, with a general northerly trend, were named the Yavapai schist by Jaggar and Palache. They continue northward into the .Jerome quadrangle, though here the exposures are much smaller.

The formation is described as follows by the authors cited:

Chiefly phyllite, mica schist, and hornblende schist, with limestone lenses, quartzite, and siliceous schist lenses. * * Within the schist areas are conglomerate and sandstone bands and lenses, and zones of intense metamorphism where the rocks are amphibolitic and contain epidote, garnet, zoisite, tourmaline, andalusite, and mica in various amounts. [There are also lenses containing much magnetite.] The typical phyllite as developed in the great body of Yavapai schist which occupies the northern half of the center of the quadrangle is a finely foliated blue or silvery schist consisting chiefly of quartz and the form of muscovite mica known as sericite. The foliation is pronounced, but the surfaces of the partings are not plane, so that nowhere are truly cleavable slates found. The rock consists largely of interlocking quartz grains, producing a mosaic, the sericite being woven in between the grains or forming layers wrapped about individual grains. Occasionally single large rounded grains of quartz are seen, their edges granulated. Plagioclase, calcite, epidote, zoisite, pyrite, and magnetite are often found in scattered grains.

The rocks are interpreted as a recrystallized and metamorphosed sedimentary series, and the conclusion is confirmed by the occurrence of lenses of quartzite, conglomerate, and, more rarely, limestone. Certain rare facies of the schist, however, contain so much feldspar in crystal form that a local derivation of the schist from granite porphyry or some such rock seems likely.

The hornblende schists are a varied assortment. They include amphibolites of doubtful derivation, some diabasic rocks, and some schists in which the hornblende seems to be derived by contact metamorphism. Near the granite staurolite, andalusite, and tourmaline appear. 
The schists have been altered by regional metamorphism and extreme compression, but also to a considerable extent by the contactmetamorphic action of intrusive granite. The total thickness of the formation is in doubt. An estimate based on sections is from 5,000 to 7,000 feet.

The preceding paragraphs summarize the conclusions of Jaggar and Palache. My own studies are far less extensive than theirs, but included detailed examinations in each of the mining districts, and the general results are set forth as follows:

The first impression given by any typical section is that of very monotonous silvery-white schists, the outcrops looking very much alike. An inspection of mine workings, however, soon shows that this appearance is deceptive, for although a great variety of rocks present this appearance on the surface, the fresh rocks below vary greatly and are greenish, dark green, and brown from biotite mica. The pure sericite schists do not predominate. The quartzite lenses are very characteristic, especially in the central part of the Bradshaw Mountains quadrangle. I should say the predominating variety is chloritic mica schist, in part doubtless of sedimentary origin. There are also small lenses of limestone, usually only a few feet thick and, on the whole, very rare. Banded magnetites occur in many places. Some of them, as those near Copper Mountain, are red jasperoids, very similar to those of Lake Superior.

The amphibolites and allied greenstones are more abundant than the map in the folio cited would indicate. In small part they may owe their origin to contact metamorphism, but most of them are schistose and altered basic igneous rocks, probably effusive. Agglomerates with a dip differing from that of the normal schistosity are present-for instance, at the Binghampton mine, near Stoddard. A large part of the schists west of Wolf Creek, in the northwestern part of the quadrangle, have this origin.

Most prominent, however, are the schistose rhyolites or rhyolite porphyries; they are present in abundance in most of the districts examined, and where they have been pressed are almost indistinguishable from the normal chloritic schists. I suspect that the large quartz grains of which Jaggar and Palache speak are really deformed phenocrysts. Practically all the rocks at the Binghampton mine are of this character. They occur also at the Blue Bell mine, in the Black Canyon, and at many other places, but in all these places real sediments are also present.

It would be fair to say, it is believed, that the Yavapai schist comprises a series of sedimentary beds with a large amount of interbedded, supracrustal igneous rocks and tuffs. To what extent the series contains intrusive rocks is difficult to say; they are undoubt- 
edly present here and there and have been made schistose with the rest. I would not dare to assign a definite thickmess to the series.

This mainly supracrustal series was closely folded and appressed and subjected to regional metamorphism. The intrusion of the granite tends to follow the schistosity, so that great bands of schist are embedded in the granite with a general northerly direction. The effects of contact metamorphism are strongly marked. Next to the granite coarse schists appear with andalusite and staurolite, and in places probably also some amphibolite. Farther away brown mica seems to be the predominating mineral. In a few places, as at the Rainbow mine, in the Turkey Creek district, there are masses of epidote and garnet with pyrite, which seem to be contact-metamorphosed limestones. The effects may extend for a mile, or even several miles, from the contact. Tourmaline developed frequently, a mineral characteristic of granitic emanations. The tourmaline found in the schist is, indeed, invariably later than the regional metamorphism.

\section{JEROME QUADRANGLE}

The southwesterly area of Yavapai schist between Prescott and Dewey is greatly injected with granite, which in places is rudely gneissoid. The injection along the western border of this area is so extensive that it is difficult in places to separate the two formations. Near the granite the rocks are mainly amphibolites, black and lustrous, as at the Bullwhacker mine, but farther east, at the bridge across Lynx Creek, there are fissile slates and cherty beds intruded by granite.

A long north-south belt about 1 mile wide of fissile, almost vertical schists continues northward from the Bradshaw Mountains quadrangle and is well exposed on the Cherry Creek road, at the Shylock mine, at the Yaeger mine, and finally in a narrow strip below the Tapeats sandstone on the west side of the Black Hills. Where the road from Dewey to Cherry Creek crosses this belt from west to east it consists first of brown and red volcanic agglomerate, followed by purple schists and finally by a belt 500 feet wide of the usual chlorite-sericite schist, all members striking N. $20^{\circ}$ E. and standing about vertical. Below the Shylock mine the same fissile schists appear, adjoined on the east by greenstone schists and granite. Similar conditions are found below the Yaeger mine.

In Lonesome Valley, north of the wagon road to Jerome, rises a complex of low hills that consist in part of a massive light-colored reddish or yellowish granite poor in dark minerals and rather finegrained. In places the rocks show schistose structure; the granite injects numerous patches of strongly altered schist. Similar rocks are found in the northern foothills of Lonesome Valley, but within a short distance to the north the pre-Cambrian rocks are covered by 
the Paleozoic sediments. In Yaeger Canyon on the road to Jeromethe greenstone series consists of fine-grained tuffs with interbedded masses of fragmental greenstone, the series dipping $45^{\circ} \mathrm{E}$. and having the usual schistosity superimposed.

In the Jerome district and adjacent parts of the Black Hills the Yavapai schist has a distinctly differing facies. The greenstones are rudely schistose, rarely fissile, and in several places show bedding by gently dipping layers of volcanic agglomerate. In the northern part of the district, about the town of Jerome, there is much rhyolite schist, usually light colored and poor in chlorite; some of it is. almost massive, the schistosity varying sharply in intensity. The rhyolite is in part clearly intrusive into the greenstone, but some of it may possibly consist of supracrustal flows. The areas of this. rock are irregular, and in places it is intimately interlocked with the greenstone schist. The strike of the schistosity is generally north-northeast, but is subject to sharp variations.

In the southern part of the district fine-grained granitic rocks are found, also intrusive in the greenstone schists. Reber thinks that there may be transitions between the aplitic granite and the rhyolite porphyry, but I do not believe that this is proved. It seems more likely that the porphyry antedates the granite, which I believe is to be correlated with the Bradshaw granite.

The smaller areas and dikes of diorite at the United Verde, Shea, and Yaeger mines are probably also to be considered as facies of the Bradshaw granite. Masses and streaks of clay slate, quartzite, banded chert, and other clearly sedimentary rocks are interbedded in the schists near Jerome, particularly near the United Verde mine. It is believed that they are earlier than or contemporaneous with the supracrustal volcanic rocks that make up the larger part of the greenstone series.

\section{CORRELATION}

There seems to be no reason why the rocks near Jerome should be separated from the Yavapai schist. They are predominantly volcanic and largely supracrustal, but if it is admitted that the same schists in the Bradshaw Mountains also contain large amounts of such rocks any distinction seems futile. I believe that all these schists, including the Pinal schist and the schists in the Mazatzal Mountains and at many other localities in central Arizona, are of approximately the same age, and that Blake's name "Arizonian" would be eminently suitable for them as a whole. In detail they differ greatly: some are almost entirely sedimentary; others contain many different kinds of igneous schistose rocks. It is hopeless to separate them except locally. From this series should be excluded the distinctly later intrusive rocks such as the diorite, the 
Bradshaw granite, and other granites, which on the whole present a much more massive appearance.

\section{ROCKS OF DOUBTFUL AGE}

\section{GRANODIORITE (QUARTZ DIORITE)}

Jaggar and Palache called attention to certain bodies of quartz diorite in the Bradshaw Mountains quadrangle which differ strikingly from the other intrusive rocks here present. There are four areas of these rocks forming rounded intrusive masses at most a few miles wide. They are the Groom Creek, Walker, McCabe, and Crown King areas. These rocks are conceded to be the youngest among the intrusive masses in the quadrangle. There are no rocks of this appearance in the Jerome quadrangle.

The typical quartz diorite is a medium-grained light-gray rock of granitic appearance, composed predominantly of snow-white triclinic feldspar, together with more or less interstitial quartz and a variable amount of hornblende and biotite, the latter sometimes wholly replacing the hornblende. The rock is noticeably free from banded or gneissic structures, and, as shown by microscopic study, its constituents are free from evidence of unusual strain. *** Its most marked characteristic in the field is the way in which it weathers into spheroidal forms. * * * Its outcrops always occupy basins [with sandy disintegrated soil]. * * * The quartz diorite is known to be the youngest plutonic intrusive in the region [because it shows intrusive contacts with all the known pre-Cambrian rocks].

It is medium to coarse grained, with hypidiomorphic texture. Both hornblende and biotite are usually present and show a tendency to crystal form. Oligoclase feldspar is the dominant mineral. Quartz, orthoclase, and microcline fill the interstices between oligoclase and ferromagnesium silicates. Titanite is always present, with some magnetite, apatite, and zircon.

Two partial analyses given by Jaggar and Palache are reproduced in the following table (Nos. 1 and 2). The composition is that of a granodiorite rather than a quartz diorite. In 1922 a preliminary analysis (No. 3) was made of an apparently typical specimen collected by me at the Sheldon mine in the Walker district. The microscopic features correspond well with those given above, except that there seems to be a larger amount of orthoclase.

Partial analyses of granodioritic rocks

\begin{tabular}{|c|c|c|c|c|c|c|c|}
\hline${ }^{\circ}$ & 1 & 2 & 3 & & 1 & 2 & 3 \\
\hline $\begin{array}{l}\mathrm{SiO}_{8} \\
\mathrm{Al}_{2} \mathrm{O}_{3} \\
\mathrm{Feg}_{3} \mathrm{O}_{3} \\
\mathrm{MgO}^{2}\end{array}$ & 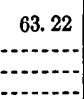 & \begin{tabular}{l}
64.23 \\
\hdashline$\ldots . .$. \\
\\
\hdashline
\end{tabular} & $\begin{array}{r}65.74 \\
16.76 \\
3.99 \\
1.70\end{array}$ & $\begin{array}{l}\mathrm{Na}_{2} \mathrm{O} \\
\mathrm{L} \mathrm{O}\end{array}$ & $\begin{array}{r}4.32 \\
2.53 \\
\ldots \ldots \ldots \\
\end{array}$ & \begin{tabular}{r}
4.90 \\
2.44 \\
\hdashline \\
\end{tabular} & $\begin{array}{r}3.37 \\
3.55 \\
.99 \\
\end{array}$ \\
\hline Cro .... & 4. 46 & 4.07 & 3. 78 & & & & 89.88 \\
\hline
\end{tabular}

1, 2. Jaggar, T. A.,jr., and Palache, Charles, op. cit., p. 5. Analyst not stated.

3. A nalyst, Helen Vassar. 
According to the quantitative system the first two analyses indicate a tonalose and the third corresponds to an adamellose. Which of these represents the average composition of the intrusive rock must be left an open question.

The pre-Cambrian of Arizona contains few if any rocks of this composition, but the rock agrees closely with the intrusives of Jurassic or later age which are so abundant in the western coast region of North America. The probability is strong that these masses were intruded in Cretaceous or early Tertiary time.

BASIC DIKE ROCKS

Basic dike rocks are not abundant in these quadrangles. There are some diorite dikes, closely affiliated with the pre-Cambrian diorite. Dikes of diabase are found at several places. Dike rocks of camptonite were observed by Jaggar and Palache at Battle Flat, at the Creek mine (near Goodwin), near Alexandra, at the Crooks mine, and in Crooks Canyon.

There is no direct evidence of the age of these dikes, but it is believed that they may well be Cretaceous or younger.

\section{DIKES OF RHYOLITE PORPHYRY}

Dikes of acidic rocks are very common. Many of aplite and more of pegmatite are associated with the Bradshaw granite. There are aiso dikes of granite that is not aplitic, as at the head of Bear Creek and Peck Canyon, which are probably related to the granodiorite.

The most abundant dikes are those of rhyolite porphyry. They are of late origin compared to the other rocks of the pre-Cambrian complex, and they intersect the granodiorite, which is believed to be of Cretaceous or later age. They occur chiefly in the western part of the Bradshaw Mountains quadrangle. Some of them can be traced for several miles. They usually strike north-northeast, roughly following the strike of the Yavapai schist. From the south the first ones are seen north of Copperopolis, also near the Tiptop mine and the Simpson ranch; the main belt continues northward across the granodiorite of the Crown King district, and the dikes are found along Peck Canyon and at Turkey Creek. They are very abundant in the Hassayampa district, near Mount Union and in the Tillie Starbuck, Senator, and N. C. 4 mines; also near Walker; and they continue northwestward across Hassayampa River into the Congress quadrangle and up to the Copper Basin district. They are intrusive in all the pre-Cambrian schists. The dikes are rarely more than 50 feet in width. 
The rock is dull white, locally porous, and usually more or less decomposed. It shows small quartz and feldspar phenocrysts, also biotite, in a gray fine-grained or flinty groundmass. Generally it is strongly altered by the development of sericite and calcite. None of these rocks can be mistaken for the rhyolite porphyry at Jerome or elsewhere in the Yavapai schist. A comparatively fresh dike near Turkey Creek station shows fine embayed quartz phenocrysts and partly altered crystals of orthoclase, with a little brown biotite, in a micropoikilitic groundmass of quartz and short feldspar laths, probably plagioclase.

The dike at the south portal of the Poland tunnel is a dull, lightgray, fine-grained rock with phenocrysts of feldspar. In thin section it shows many large and small crystals of feldspar, many of orthoclase but some of andesine. There are also muscovite foils, pseudomorphic after biotite. The groundmass is microcrystalline and consists of quartz and feldspar: Much sericite and calcite indicate strong alteration. Entirely similar to this is a dike from the summit of the road to the Mount Union mine from Prescott.

Another dike observed near the Tiptop shaft, in the Tiptop district, is a dull-white rock with a few phenocrysts of orthoclase, which in thin section prove to be strongly sericitized. The groundmass is microcrystalline and consists of quartz and orthoclase, the latter likewise much sericitized. There are also pseudomorphs of muscovite after biotite.

Different from this is the wide dike at the Springfield mine, in the Crown King district, which intersects granodiorite. This dike consists of a coarse porphyry with very abundant phenocrysts of quartz, orthoclase, and oligoclase-andesine in a rather coarse holocrystalline groundmass of quartz and orthoclase. The quartz phenocrysts contain plentiful large fluid inclusions with bubbles and colorless cubes, probably of an alkaline chloride. A similar rock is the porphyry at Copper Basin, 12 miles west of Prescott.

Two analyses were made, both of more or less altered dike rocks, as follows:

Analyses of acidic porphyries

[Analyst, Helen Vassar]

\begin{tabular}{|c|c|c|c|c|c|}
\hline & 1 & 2 & & 1 & 2 \\
\hline \multirow{2}{*}{ 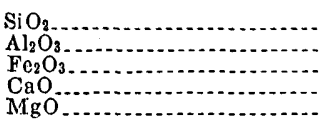 } & \multirow{2}{*}{$\begin{array}{r}71.20 \\
17.57 \\
1.50 \\
.37 \\
.21\end{array}$} & \multirow{2}{*}{$\begin{array}{r}65.83 \\
15.76 \\
2.51 \\
3.16 \\
.79\end{array}$} & \multirow[t]{2}{*}{$\begin{array}{l}\mathrm{Na}_{2} \mathrm{O} \\
\mathrm{K} \mathrm{O}_{2}\end{array}$} & $\begin{array}{l}0.05 \\
5.92 \\
2.86\end{array}$ & $\begin{array}{l}2.84 \\
4.15 \\
5.41\end{array}$ \\
\hline & & & & 99.68 & 100.45 \\
\hline
\end{tabular}

1. Tiptop mine.

2. South portal of Poland tunnel. $68508-26-3$ 
The rocks are greatly altered; it is clear, however, that the rock from the Tiptop mine is a rhyolite porphyry and that from the Poland tunnel approaches much more closely a trachytic composition.

The acidic dike rocks are most intimately connected with the later mineralization of the Bradshaw Mountains quadrangle. The evidence of that mineralization points definitely to lesser depths and lesser temperatures than those prevailing in the mineralization that followed the intrusion of the Bradshaw granite. It is concluded that the dikes were introduced after the region had undergone a great deal of erosion. It is also certain that the dikes are much later than the Bradshaw granite. As they are also later than the granodiorite we may tentatively conclude that they were intruded in Cretaceous or Tertiary time.

I have not seen the thick dike of rhyolite porphyry in the New River Mountains, described by Jaggar and Palache. It is situated in the extreme southeast corner of the quadrangle, and they state that it differs but little from the [Tertiary] rhyolite flows of the same vicinity. No ore deposits have been discovered near by.

On the map (pl. 2) the quartz diorite and the rhyolite porphyry dikes are indicated as "probably Algonkian." This was the view of Jaggar and Palache.

\section{ORE DEPOSITS}

\section{MINERAIS OF THE ORE DEPOSITS}

The deposits of this region are not remarkable for variety and beauty of minerals. Only 51 species have been identified.

Quartz.-As usual, quartz is the most abundant gangue mineral. In the pre-Cambrian veins the quartz has a glassy appearance and forms a coarse granular mass. Druses and vugs as well as comb structure are absent. Locally, as near the Monarch mine, in the Black Hills, large crystals are found, but these occurrences rather indicate a transition to pegmatite. In much of the rock the grains are extremely crushed, as indicated by their optical character, and full of fluid inclusions, with moving bubbles which do not disappear on gentle heating. They are, therefore, not fluid carbon dioxide.

The quartz in the pyritic replacement deposits is of finer grain and less crushed than in the veins just described.

In the later (post-Cambrian) veins the quartz is milky white and shows little optical deformation. Druses, vugs, and comb structure are characteristically present. The crystals are small, the largest individuals observed, in the Tiptop mine, reaching only 2 or 3 inches in length in the comb aggregates. 
In some of these deposits, as at the Tillie Starbuck and Davis mines, the quartz is fine grained. Vugs are coated with thin layers of bluish chalcedony at the Tiptop mine. The quartz of the Springfield copper deposit at Crown King contains large fluid inclusions with inclosed colorless cubes, probably an alkaline chloride.

Rutile.-Rutile is present in the ores of some pyritic replacement deposits.

Calcite.-In some of the later veins calcite is not uncommon but is usually the latest gangue mineral, covering the quartz and containing no sulphides. It occurs also in the pyritic replacement deposits and in the Yavapai schist.

Siderite.-Some of the pre-Cambrian veins in the Black Hills (Shea, Yaeger, and others) contain siderite in abundance. It is of yellowish color and is associated with tennantite, bornite, and other sulphides.

Ankerite.-The isomorphous mixtures of the carbonates of calcium, magnesium, and iron are here placed together under the term ankerite. They form the most common gangue mineral next to quartz and occur in practically all the later veins, though usually more abundant in the veins carrying much silver. The ankerite is dull white with a brownish or pale-pink tinge and is very commonly intergrown with sulphides.

Dolomite.-Dolomite is found in many of the veins; it is common in some of the pyritic replacement deposits.

Barite.-Though not a common gangue mineral in this region, barite has been observed in some silver-bearing deposits (N. C. 4, Silver Belt, and Tuscumbia veins). It is associated with tetrahedrite, galena, and sphalerite.

Fluorite.-Fluorite is rare. A purple variety occurs in small quantities in the Evening Star silver vein, at Venezia; the Springfield copper deposit, at Crown King; and the Swallow mine, near Copperopolis.

Sericite.-In the later veins sericitic alteration of the country rock is very common and in places the sericite is intergrown in small aggregates with the quartz.

Adularia.-As a rule adularia is foreign to the veins in this region. It was observed, however, intergrown with magnetite and specularite in the unusual association of the Cash veins, described in some detail on page 122. The veins are of the later type. Adularia was also noted in thin sections from the Springfield mine.

Albite.-Albite is an abundant gangue mineral in the Springfield copper deposit, at Crown King, where it forms a granular mass intergrown with quartz. Many of the grains show no polysynthetic twinning. This is the only occurrence of albite noted in the ore deposits of the region. 
Chlorite.-Chlorite occurs in places as a product of alteration of the wall rocks but is rarely found in the vein itself. A dark-green, almost black, dense variety which is rich in iron occurs in some of the pyritic schist deposits-for instance, at the United Verde-and is here properly a gangue mineral.

Epidote.-Though occurring in altered wall rocks near some veins, epidote is not a common gangue mineral. It is associated with pyrrhotite in the Rainbow deposit, at Turkey station, and in the Boggs mine, at Mayer, but in both of these places it apparently resulted from the action of high-temperature emanations on limestone lenses in the Yavapai schist.

Garnet.-A grossularite or andradite garnet forms with epidote the gangue at the Boggs mine, at Mayer. In places it occurs with magnetite in the Yavapai schist, probably as a product of igneous metamorphism.

Actinotite.-At the Boggs mine radial actinolite occurs with garnet, epidote, and sulphides.

Tourmatine.-Black tourmaline is characteristic of the emanations resulting from the intrusion of the Bradshaw granite into the Yavapai schist. Near the contact much of the schist contains microscopic tourmaline, which always shows its later introduction. Tourmaline is also found near the contact in pegmatite dikes and in quartz injections. The pre-Cambrian veins characteristically carry black tourmaline intergrown with quartz. The mineral is not always readily recognizable; much of it appears as black or darkgreen dense aggregates identifiable only under the microscope. Such tourmaline occurs, for instance, in the Richinbar, Lehman, and Cherry Creek mines. 'Tourmaline is absent from all the pyritic schist deposits and from all the later veins.

Specularite.-Specularite (hematite) is found occasionally, with magnetite, in the pyritic schist deposits but is not characteristic. In the pre-Cambrian veins it is absent, but it appears with magnetite in the unusual Senator type of the later veins. It also occurs as a product of oxidation of pyritic deposits-for instance, at the United Verde, at the Cherry Creek veins, and near Copperopolis. (See pl. 15, A.)

Magnetite.-Magnetite is found at some places in the Yavapai schist, in considerable masses, though probably not of economic importance (p. 35). In the pyritic deposits it occurs here and there-for instance, at the United Verde mine-but is not abuindant. In the veins it is absent except in those of the unusual Senator type, where it is an early vein mineral associated with adularia and specularite.

Pyrite.-As usual, pyrite is present in practically all the deposits. It is very abundant in the pyritic schist ores and occurs in greater or 
less abundance in all veins. It is locally crystallized in cubes and pyritohedrons and is everywhere one of the very earliest metallic minerals. Pseudomorphs of limonite after pyrite in cubes 1 or 2 inches on a side were noted in a specimen from a vein near the Monarch mine, in the Black Hills.

Marcasite.-The only known occurrence of marcasite is at the Iron Queen mine, where it replaces the other sulphicles as rounded and reniform aggregates, evidently crystallized from a colloidal state (p. $140 ;$ pl. $15, B)$.

Pyprhotite.-Pyrrhotite is rare but is found in massive form at the Rainbow deposit, near Turkey Creek station.

Chalcocite.-As a product of sulphide enrichment by descending waters at or above the water level chalcocite, usually in sooty or dull aggregates, is found in almost every deposit where the primary ore carries chalcopyrite, bornite, or tetrahedrite. Few of the veins or deposits in this region show a well-defined chalcocite zone. The mineral is fairly abundant in the upper levels of the United Verde mine and in a thin but well-marked zone in the Copper Chief mine, south of Jerome. Very large masses of chalcocite occur in the preCambrian enriched zone in the United Verde Extension mine, with cuprite and native copper. Here some of it is massive and has a metallic luster. The massive form also occurs at the Pittsburg Tunnel, on Mescal Gulch at Jerome, and at Copper Mountain, near Mayer.

Covellite.--Except in minute aggregates with chalcocite, covellite is rarely seen in the region. Very fine specimens were, however, obtained from the United Verde Extension mine.

Molybdenite.-There are practically no important occurrences of molybdenite in the two quadrangles. Just west of the Bradshaw Mountains quadrangle, in Copper Basin, considerable quantities of the mineral occur in one of the deposits of the younger type in connection with granite porphyry. It is here associated with pyrite and chalcopyrite, and shipments of the mineral have been made from this locality. Molybdenite is said to occur in a presumably preCambrian quartz vein on a ridge west of Venezia.

Sphalerite.-The isometric zinc sulphide is one of the commonest minerals in all ore deposits in the area described, but it is rarely of economic importance. It is present in many pre-Cambrian quartz veins; it is also common in the pyritic deposits in schists, and zinc concentrates have been shipped from the Binghampton mine. It is abundant in the United Verde mine and is present in practically all the deposits of the younger type, mainly fissure veins. Usually it is dark brown; more rarely, as at the De Soto and United Verde, both pyritic schist deposits, it is of lighter color. According to V. C. 
Heikes, ${ }^{10}$ the shipments of zinc in crude ore or concentrates from Yavapai County amounted to 357,380 pounds in $1918,1,717,000$ pounds in 1919, 1,457,296 pounds in 1920, and none in 1921, 1922, and 1923. The zinc is always a by-product.

Galena.-The lead sulphide is almost as widely distributed as sphalerite. It occurs in a few of the pre-Cambrian veins and is rarely seen in the pyritic schist deposits but is most common in the veins of the younger type, from which shipments of crude ore and concentrates are made in many districts. In these veins it is associated with drusy quartz, ankerite, and more rarely with barite. Galena is always one of the youngest ore minerals in any given association.

Shipments of lead in crude ore and concentrates from Yavapai County amounted, according to Heikes, to 348,389 pounds in 1918, 237,605 pounds in $1919,238,296$ pounds in $1920,172,150$ pounds in $1921,82,199$ pounds in 1922, and 216,612 pounds in 1923 . The lead also may be considered as a by-product.

Argentite.-Although argentite was doubtless of common occurrence in the now largely exhausted rich oxidized silver ore, it was rarely seen during the present examination. In some of the galena (Arizona National mine) it is rather abundant in microscopic crystals, and it was observed in a polished section of partly oxidized ore from the Cougar mine, at Crown King, as a peripheral replacement of galena and sphalerite (pl. 14, B).

Stibnite.-Radial aggregates of stibnite were observed at the 76 mine, in the Tiptop district. Stibnite is also reported from a vein in the Battle Flat area and from the White Spar mine, on the west side of Hassayampa River, in the Congress quadrangle. It is confined to veins of the younger type associated with Mesozoic (?) intrusive rocks.

Bismuthinite.-A specimen of bismuthinite was obtained from the Swallow mine, in the Castle Creek district, probably also one of the younger type of deposits. It is a crystalline coarse fibrous aggregate largely altered to bismuth ocher and surrounded by radiating quartz crystals.

Bournonite.-The only known occurrence of bournonite in this area is at the Boggs mine, near Mayer, which has been idle for many years. It is intergrown with calcite in imperfect crystals a few millimeters thick and is associated with arsenopyrite and the more common sulphides. It seems to be the latest mineral in this association. The occurrence is mentioned in Dana's "System of mineralogy."

Tennantite.-In the pre-Cambrian pyritic deposits tennantite is not uncommon, though it rarely occurs in large quantities. It is

${ }^{10}$ U. S. Geol. Survey Mineral Resources. 
found with ankerite or siderite, locally in later veinlets and small masses, but nowhere in distinct crystals. It is most abundant at the United Verde mine, where the mineral contains a notable amount of silver.

Tetrahedrite.-In the later gold-silver veins tetrahedrite is of common occurrence, though there is rarely much of it. It is invariably argentiferous and in places strongly so. It usually contains some arsenic. Crystals have not been observed. Together with argentite in galena, tetrahedrite is the source of silver enrichment by descending solutions. It is found in the N. C. 4 vein (with barite), practically all the veins in the Crown King district, the McCabe vein, the Sheldon vein, and many others. The variety freibergite was identified in specimens from the Buzzard mine and the Black Warrior and Silver Prince (Swastika mine). It is commonly associated with sphalerite and galena (Arizona National mine). It also occurs in pyritic replacement deposits, and here it always contains some arsenic, as at the Binghampton, Kay, and other deposits. Considerable amounts of tetrahedrite ore have been shipped from the Shea vein, a pre-Cambrian deposit.

Arsenopyrite.-Many, if not all, of the pyritic schist deposits contain a little arsenopyrite, in places well crystallized (Boggs mine). The United Verde, Binghampton, Blue Bell, and De Soto are among the mines where this mineral was noted. Larger aggregates of massive arsenopyrite occur in the Blue Dick, Mark Twain, and Buzzard veins and may possibly be of some economic importance. Arsenopyrite is also found in some of the veins of the later series, as at Tiptop, Sheldon, and other places.

Chalcopyrite.-Chalcopyrite is the most common and most valuable ore mineral of the region. It is of universal occurrence in the pyritic schist deposits, appears here and there in the pre-Cambrian quartz veins, and is almost invariably present in the veins of the later series, though here not of much economic value. In the leadsilver veins with barite or ankerite gangue it is scant or absent, and its place is taken by tetrahedrite. It nowhere shows crystal forms.

Bornite.-Bornite is not a common mineral in this region. Fine specimens of the massive mineral were collected from the ore pile of the Yaeger mine, near the road from Prescott to Jerome. A little bornite was seen in polished sections from the Tiptop mine. It has been observed in the United Verde mine and in the Cherry Creek veins.

Pyrargyrite and proustite.-Both ruby-silver minerals were observed, proustite perhaps more commonly than pyrargyrite. As a primary mineral proustite was noted in the Davis and Tillie Starbuck mines, on Mount Tritle, and at a few other places. Pyrargyrite was noted in specimens from the Thunderbolt mine, in Black Can- 
yon. Ruby silver is commonly reported as having occurred more or less abundantly in many of the rich oxidized silver ores formerly. mined-for instance, at the Tiptop, Tiger, and other places where it is now absent in the primary ore. It is believed that these minerals are in part of supergene origin (deposited by descending waters). No well-developed crystals were observed.

Gold.-Native gold of ordinary fineness (about 0.850 ) is found in the placer deposits along recent streams. Coarse gold of deep yellow color is often seen in the pre-Cambrian quartz veins, particularly at the Monarch mine, in the Black Hills. In the pyritic schist deposits visible gold is apparently absent, though it has been set free in many of the oxidized outcrops. In the veins of later type free gold is rarely seen, except in the zone of oxidation. Coarse gold appeared with sulphides in the Crown King mine, but in most places it is probably disseminated in the sulphides in microscopic or submicroscopic particles.

Silver.-Native silver occurs so far as known only in the partly or wholly oxidized silver ores of the later veins (Arizona National mine). It is reported from almost all the mines noted for such rich ores.

Copper--Native copper is not uncommon in the oxidized ores of all kinds, particularly in the pyritic schist deposits. It is particularly abundant in the United Verde Extension mine, where it occurs with chalcocite and cuprite.

Cuprite.-Cuprite is often found in the oxidized ores of copper deposits, particularly in those of the pyritic bodies in schist. It occurs abundantly and well crystallized, in part as chalcotrichite, in the United Verde Extension mine.

Copper carbonates.-Malachite and azurite are common, though rarely in quantity, in the oxidized ores, particularly in those of the pyritic schist deposits.

Chrysocolla.-The oxidized ores of the veins in the Castle Creek district, which is situated in the "torrid zone," carry characteristically blue chrysocolla, copper pitch ore, native copper, limonite, and secondary specularite. Chrysocolla is the important ore mined in the gravel of the Dundee-Arizona mine at Jerome.

Anglesite and cerusite.-As oxidation products of galena anglesite and cerusite are not uncommon, though rarely of any economic importance. Anglesite on galena was particularly noted in a specimen from the Big Lead vein, at Copperopolis.

Vanadinite.-Vanadium minerals are rare; one occurrence of vanadinite is reported from a prospect just north of the Silver Belt line, at Humboldt.

Wolframite.-Tungsten minerals are rare in this region. They have been found thus far only in the Tiptop district (p. 180), where 
the tungstate occurs in brown prisms as the earliest mineral in silver veins of the later type. The material has not been analyzed, but its appearance points to hübnerite rather than to wolframite.

Limonite.-Limonite, generally earthy, is common in the oxidized zone. Rarely it is accompanied by pyrolusite or wad.

Kaotin.-Kaolin is naturally present in much of the oxidized ore. It was never observed as a constituent of primary ore.

Gypsum:-Gypsum is often found in the oxidized zone. It is abundant in the decomposed dikes of the United Verde mine.

\section{GENERAT CLASSIFICATION}

The discussion of the mineral deposits in the region is naturally limited to ore deposits, as the nonmetallic minerals are of little value. A little limestone may be used here and there for burning, and the banded travertine, or "onyx marble," in the Quaternary hot-spring deposit at Mayer has been employed to some extent for flux and ornamental stones. Of building stones there is a good supply of granite and locally of rhyolite tuff, but there is little demand. A large deposit of sodium sulphate occurs in the Verde lake beds near Camp Verde and has been described by W. P. Blake and O. P. Jenkins. (See p. 14.)

The ore deposits may be divided as follows:

Pre-Cambrian ore deposits:

Pyritic copper deposits in schist.

Magnetite deposits.

Contact-metamorphic deposits.

Gold-quartz veins.

Gold-quartz tourmaline replacement deposits.

Quartz veins carrying silver, copper, and lead.

Later gold and silver veins (Mesozoic? or early Tertiary?).

Quartz veins carrying gold and silver.

Silver veins :

Veins with barite gangue.

Veins with quartz gangue.

There are no ore deposits in the region to which an age later than that of the Tertiary volcanic flows can be assigned.

\section{PRE-CAMBRIAN ORE DEPOSITS}

The evidence for the age of the deposits listed as pre-Cambrian is in part direct and positive, in part indirect. In the Jerome district the Paleozoic sediments cover the oxidized and chalcocitized pyritic replacement deposits, and there is no evidence of any mineralization of the limestones. In the Cherry Creek district the quartz veins do not penetrate up into the Paleozoic basal beds.

In the Bradshaw Mountains quadrangle the evidence is not so positive, owing to the absence of Paleozoic beds, but the character $68508-26-4$ 
of the deposits themselves is clear enough. They are of a deepseated type, they are in part identical in genesis with those of Jerome and Cherry Creek, and their relationship with the Bradshaw granite is too evident to be overlooked.

The deposits have this in common-that they were formed long before the development of the pre-Cambrian peneplain upon which the Paleozoic beds were laid down. Their present outcrops are in many places at or close to that peneplain, the development of which was not accompanied by any mineralization except oxidizing and enriching processes. A great thickness, in places probably many thousand feet, was eroded before the present outcrops were exposed to daylight.

\section{PYRITIC COPPER DEPOSITS IN SCHIST}

\section{GENERAI CHARACTER AND FORM}

The pyritic copper deposits are the most valuable in the region and have produced far more than all other deposits put together, the combined value of the output certainly being above $\$ 130,000,000$. They are replacement deposits in schist and contain pyrite, chalcopyrite, sphalerite, arsenopyrite, and tetrahedrite or tennantite in a gangue of quartz, dolomite, ankerite, and sericite. The replaced rocks may be rhyolite schist, greenstone schist, biotite schist, or chlorite-sericite schist of probably sedimentary origin. The form is tabular, lenticular, or more or less rudely cylindrical. The principal deposit at the United Verde mine (fig. 4) is a steeply dipping cylindrical body 700 or 800 feet in diameter extending down to a depth of 2,400 feet, or 3,100 feet counted from the level of the preCambrian peneplain; that of the United Verde Extension is a smaller body, gradually tapering, greatly enriched by pre-Cambrian descending surface waters. The deposit at the Blue Bell includes a number of thin, in part overlapping lenses which have been followed down to a depth of 1,500 feet and which are traceable for 1,600 feet horizontally. Similarly the De Soto deposit consists of seven overlapping lenses of tapering form, most of them coming to a point 900 feet below the outcrop.

The Binghampton mine has three lenses 10 to 15 feet in maximum width, one of which, at least, is 100 feet long and extends down to the 600 -foot level.

The mineralization tends to follow the schistosity, which is preserved in much of the ore. There is almost everywhere strong evidence of crushing and fracturing after the deposition of the pyrite, and the chalcopyrite in many places occupies the fractures.

The ores contain as much as 10 per cent of copper, though most of the mines have yielded ore containing from 3 to 5 per cent. In places, as at the United Verde, there are large masses of pyrite with 


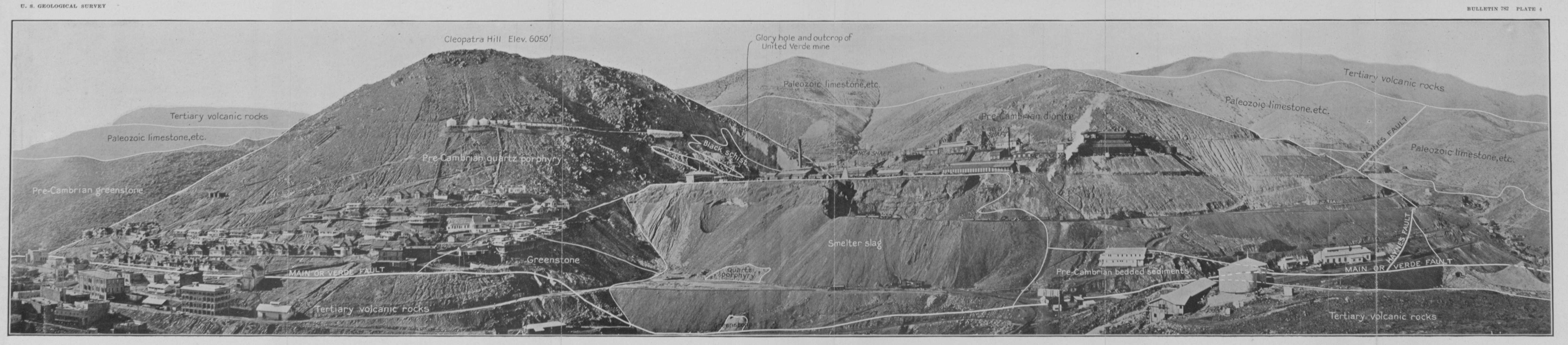


very little chalcopyrite in which the copper ores occur as shoots that follow the schistosity. There are also lenses and masses of slightly mineralized schist and of strongly silicified schist.

In the Jerome quadrangle the deposits center at Jerome (see pl. 4), though there are also scattered occurrences of somewhat mineralized schist in the central part of the Black Hills, along their western foothills and the north edge of Lonesome Valley.

In the Bradshaw Mountains quadrangle most of the deposits follow the eastern schist belt by Copper Mountain, Blue Bell, and Black Canyon and down to the mouth of Agua Fria Canyon. A few deposits are also found in the western schist belt, among which that of the De Soto mine is the most important.

\section{CHARACTER OF REPLACEMENT}

The raw material on which the metal-bearing solutions worked was everywhere schist. In part the rocks were chlorite-sericite schists of uncertain origin; in large part they were schistose rhyolite porphyry, as at the United Verde, Binghampton, and Blue Bell (in part), and probably also at the Howard copper mine. In part they were of undoubted sedimentary origin, as at the United Verde and the Blue Bell (in part). The ores have in many places inherited the schistose structure, but no schistosity has been superimposed upon them. The ores are similar in character throughout.

The action began by replacement of the schist minerals by quartz and carbonates; the carbonates are in part calcite, but more commonly dolomite and ankerite; siderite is not common. The result is a quartz mosaic of varying grain, the individuals being rarely crushed or optically deformed. The carbonates are in the main later than the quartz, but deposition of gangue minerals accompanied the sulphides also. Toward the end-that is, with the deposition of tetrahedrite and tennantite-little quartz but a considerable amount of clolomite was deposited. Though many ores contain some sericite, not much of this mineral was formed, and there is no extensive sericitization such as is so common in other deposits. A dark-green chlorite with fairly strong birefringence accompanied the deposition of the sulphides in many places, particularly just before the introduction of chalcopyrite. This chlorite is apparently a variety rich in iron, allied to prochlorite or aphrosiderite.

The final result is a mosaic of quartz and dolomite or a similar carbonate with or without chlorite, in which are embedded cubes and anhedrons of pyrite and anhedrons of other sulphides. The sulphides are deposited in unvarying order, the later replacing the earlier sulphides or the gangue. 
Arsenopyrite in scattered crystals is probably the earliest sulphide, though its age relatively to pyrite is not always easy to determine. It is invariably present, though in very scant amount.

Pyrite came next, in small cubes or anhedrons. In places quartz seems to radiate from it in straight or curved streamers. The deposition of pyrite was almost everywhere followed by the fracturing and shattering before mentioned, which really was the effect of closely spaced jointing, locally in three directions.

Magnetite, replaced in part by specularite, is normally absent but appears in some parts of the United Verde ore body. Here these minerals followed the pyrite and were replaced by later sulphides. Benedict ${ }^{20}$ suggests that their presence may have been caused by a heat wave produced by the many dikes of diorite porphyry that were injected into the deposit during the mineralization.

Sphalerite, closely followed by chalcopyrite, was next introduced. It replaces pyrite extensively and is present in all deposits; it is very abundant in certain parts of the United Verde mine. The sphalerite is usually of light-brown color, but in slides from the United Verde mine it is pale yellow or gray with a dark rim, which is in no way indicated in the corresponding polished section. There is no disseminated chalcopyrite in the sphalerite. The mineral was deposited around the periphery of the pyrite and also replaced it, so that a mass of the zinc sulphide may contain many rounded residuals of pyrite.

In some specimens (pl. 10, $A$ ) veinlets of quartz with sphalerite and a little chalcopyrite cut across the products of the earlier mineralization. In the same specimens there are still later veinlets of calcite with a little sphalerite and chalcopyrite.

A streaky or banded appearance is common and is determined by pyrite, sphalerite, or chalcopyrite following the lines of schistosity.

The chalcopyrite followed the sphalerite and replaced the earlier minerals of gangue and sulphides. It is found mainly in the shattered pyrite, replacing it and filling the interstices (pl. 11, $A$ ). In many places where it occurs in abundance it is associated with the confused radial masses of iron chlorite and may replace that mineral.

Galena occurs scantily in small scattered grains and seems to have followed chalcopyrite and tennantite.

One of the last minerals to form was tennantite (United Verde) or arsenical tetrahedrite; it replaced any of the older minerals and occurs in small amounts in almost every one of the deposits. Frequently it is seen in veinlets cutting across the deposits formed by the older mineralization and is associated with dolomite.

${ }^{20}$ Benedict, P. C., unpublished thesis, Massachusetts Inst. Technology, 1923. 
ORIGIN OF THE REPLACEMENT DEPOSITS

There is some difficulty in interpreting the origin of these pyritic replacement deposits. Their great similarity is striking, as is the fact that they can not be connected with any definite rock. Clearly the schists and the supracrustal igneous rocks they contain have nothing to do with the origin of the deposits, whose wide distribution and similar character would seem to indicate an origin from some deep-seated source. There is nothing to connect them definitely with the Bradshaw granite or its dioritic facies, though at the United Verde the diorite is the latest intrusive, having been injected after the schistosity had developed. At other places, however, there is no granite or diorite in the vicinity of these deposits. The pipelike form of the principal deposit, that of the United Verde mine (fig. 4), and the fact that it persists down to a level at least 3,200 feet below the pre-Cambrian peneplain certainly indicate mobile solutions ascending under tremendous pressure.

At first glance the mineralization gives no clue to the origin, but the absence of strongly marked sericitization and the presence of an iron-rich chlorite point to a high temperature. Certainly the deposits were not derived from the differentiation products of the Bradshaw granite, like the tourmalinic gold quartz veins. Probably they came from greater depth, perhaps from the granitic magma but from levels where mineralizers like fluorine, boron, and phosphorus had not yet separated to any great degree. These magmatic fluid emanations penetrated the rocks along lines or channels of weakness and diffused through the rocks on their upward path. They deposited their load of sulphides and quartz and rapidly took up the waste products of replacement, thus changing their composition from magmatic fluids to mixed fluids, which probably did not differ greatly from some of the deep-seated thermal springs that now in many places on the earth discharge their waters at the surface.

\section{MAGNEIITE DEPOSITS}

At several places in the region the schists contain magnetite, here and there so much that they may be considered iron ores, though it is unlikely that they will ever be utilized. The gangue is quartz and silicates, so that they are not suitable for flux. These magnetite ores are generally banded and locally contorted and alternating with red jasper, and they seem to be of sedimentary origin. In fact, some specimens found near Copper Mountain and also at the United Verde mine are very similar to the Lake Superior iron formations. Jaggar and Palache describe material from a place 2 miles southwest of Bueno, which is essentially a banded quartzite with small amounts of 
garnet, epidote, hornblende, and tourmaline and streaks of magnetite. Here the magnetite makes up about 50 per cent of the rock.

Another occurrence is 11/4 miles north of White's ranch, in Minnehaha Flat, where a mica schist is rich in sharply crystallized garnet and in magnetite.

Other very similar occurrences of banded magnetites were found during the present examination on Turkey Creek 1 mile southeast of Turkey Creek station along the road and in Black Canyon 1 mile south of the Howard Copper Co.'s property. At both places the magnetite is associated with quartzite and contains siliceous material.

Many of the Yavapai schists contain metacrysts of magnetite with tails of quartz (pl. 5, $A$ ) and tourmaline, and it is thought that these two minerals, which are distinctly later than the general schistosity, were introduced by solutions emanating from the Bradshaw granite at the time of its intrusion. Just what part this metamorphism played in the development of the magnetite schists is not certain. It is certain, however, that indications of igneous metamorphism appear in the schists at many places, especially where they contain calcareous material. In fact, it seems clear that almost the whole of the Yavapai schist body has been more or less penetrated by granitic emanations.

\section{CONTACT-METAMORPHIC DEPOSITS}

The deposit on Turkey Creek known as the Rainbow lode (p. 154) bears the earmarks of a lens of contact-metamorphic limestone. It is a lenticular body of pyrite, pyrrhotite, and a little chalcopyrite, with an abundant gangue of coarse epidote and residual calcite. There is also a little deep-brown biotite ${ }^{\circ}$ and magnetite. At the Blue Bell mine the schists are calcareous and contain small lenses of limestone. I understand that Prof. Charles P. Berkey, who rendered a report to the company on the rocks of the deposits, found some garnet, which he regards as part of the schist series and as having no direct relation to the deposit.

Near Mayer are the old pyritic schist deposits of the Hackberry, Boggs, and Iron Queen mines, all now closed and inaccessible. In the dump of the Hackberry mine, besides prevailing chloritic schist, was found granular magnetite with radial amphibole. At the Iron Queen mine the chloritic schist contains thin bands of andradite or grossularite garnet with a little magnetite. At the Boggs mine specimens were obtained showing yellow garnet, actinolite, epidote, and residual calcite; all these silicates have replaced the quartz mosaic of the schist. The mosaic and the calcic silicates are replaced by sphalerite, chalcopyrite, and magnetite. It is thought that this material represents a type of contact-metamorphic' 


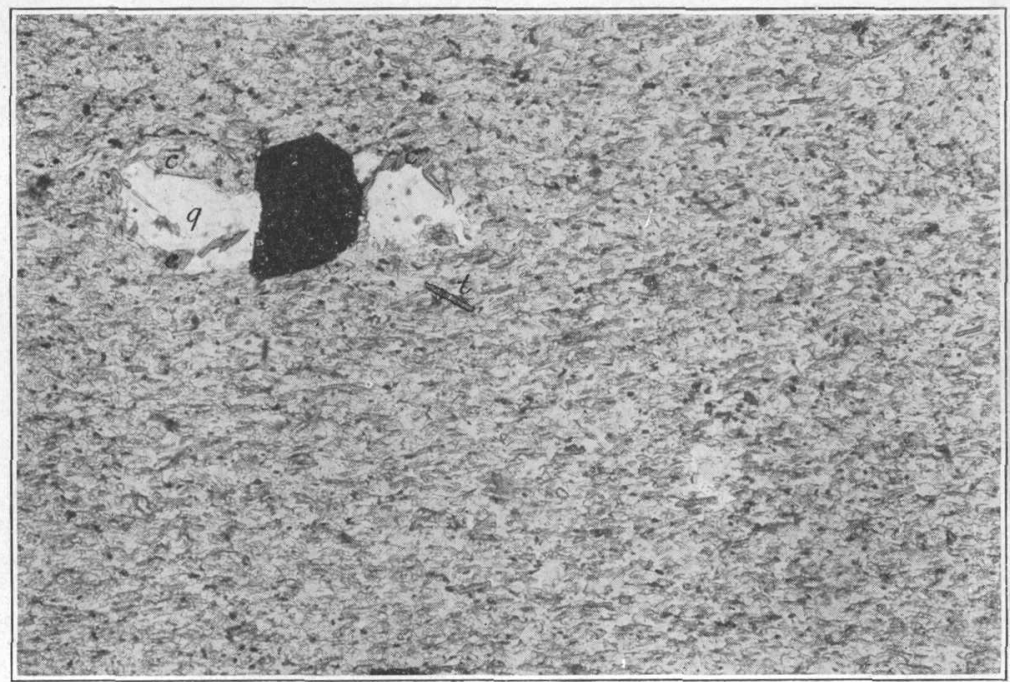

A. PHOTOMICROGRAPH OF THIN SECTION SHOWING YAVAPAI SCHIST

Matrix of chlorite (c), sericite, and quartz, with metacrysts of magnetite (black), quartz tails $(q)$, and prisms of tourmaline $(t)$. Enlarged 32 diameters. Ordinary light

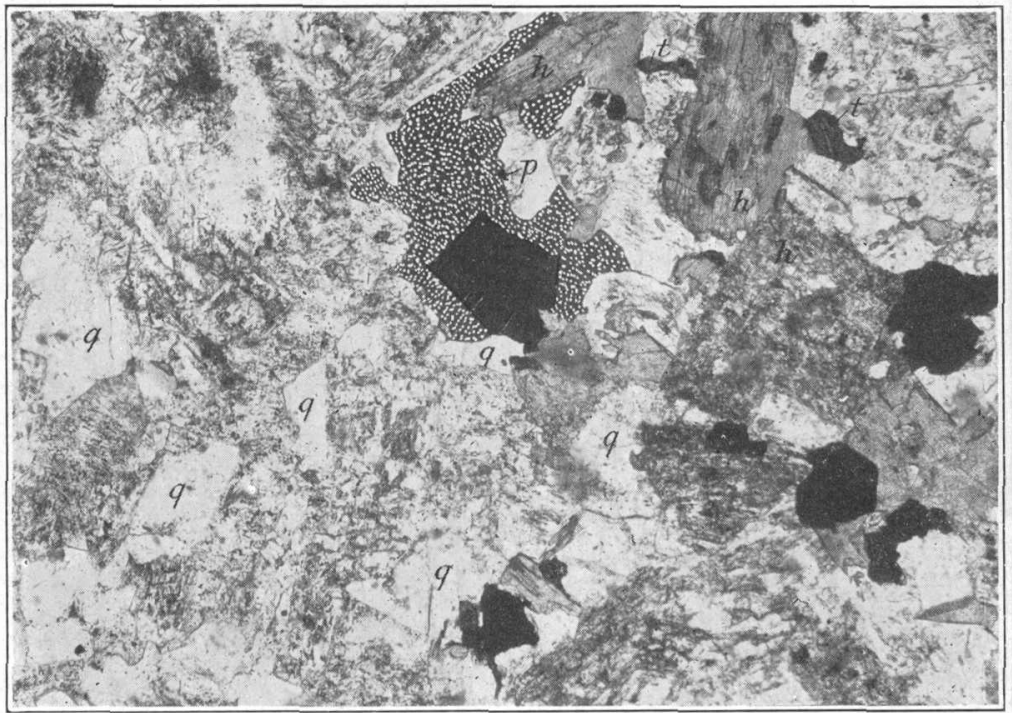

B. PHOTOMICROGRAPH OF THIN SECTION SHOWING GRANODIORITE OF WALKER DISTRICT

Andesine-oligoclase, quartz $(q)$, biotite, hornblende $(h)$, titanite $(t)$, magnetite (black), and pyrite (stippled). Enlarged 32 diameters. Ordinary light 
ore which was already in existence when the main pyritic replacement deposit in chloritic schist was formed. In other words, the schist contained thin limestone lenses which were metamorphosed by granitic emanations, and later the pyritic ores, on which the mine was worked, came into existence.

A specimen of apparently amphibolitic wall rock from the Henrietta mine, 2 miles north of Mayer, proved to be a quartz mosaic with some albite which contained much diopside, some magnetite, and residual calcite-evidently a contact-metamorphic product of an original calcareous rock.

In conclusion, the widespread soaking of the Yavapai schist in granitic emanations is evident. It is believed that all the scattered tourmaline in the schist has this origin. Valuable deposits would probably have been developed had the original sediments contained more than a few thin lenses of limestone.

\section{GOLD-QUARTZ-TOURMALINE REPLACEMENT DEPOSITS}

The absence of tourmaline from the normal type of pyritic replacement ores carrying copper has already been noted. There is one deposit, however, of the unusual type containing gold, quartz, and tourmaline.

The Iron King mine (p. 127), in the Yavapai schist about a mile west of the Humboldt smelter, has been worked for gold and silver and is said to contain considerable low-grade ore. The deposit forms a series of overlapping lenses, in all 75 feet wide, in which the schist is highly silicified and banded by the introduction of finegrained sulphides, mainly pyrite, with a gangue of granular quartz, tourmaline, and some dolomite. The sulphides are, in order of age, arsenopyrite (oldest), pyrite, sphalerite, and galena. Intergrown with the sulphides are abundant prisms of bluish tourmaline.

This deposit is regarded as of the same age as the gold-quartztourmaline veins and is believed to have been formed by the emanations from the granite.

\section{GOLD QUARTZ VEINS}

\section{GENERAL CHARACTER}

There are many gold quartz veins in this region. Among them there are a number which stand out with rather definite characteristics. They occur in granite or schist but not, so far as known, in granodiorite; the quartz is massive, without druses; a rude banding of the various constituents is locally apparent, but there is no crustification. The mineralization is simple; besides predominating quartz there may be a little ankerite or siderite; tourmaline has 
been found so often that it is considered a typical though usually scant gangue mineral. The quartz is invariably strained and crushed and occurs in lenses along the course of the vein. The sulphides consist of pyrite, chalcopyrite, sphalerite, and galena, but they occur scantily. Free gold is present, much of it in visible particles. The alteration of the country rock is slight. In regions where the Paleozoic beds cover the pre-Cambrian, these younger beds are barren, showing no mineralization whatever.

These veins have been classed as of pre-Cambrian age, and their genetic connection with the intrusion of the Bradshaw granite may be regarded as proved. Besides the structure, which points unerringly to deep-seated conditions, the presence of tourmaline points directly to the granites. The intrusion of this rock was accompanied by boron emanations, which produced tourmaline that is not only disseminated in the schists near the contact but also is characteristic of the many pegmatite veins that are found along the contacts. The pegmatites, however, form a distinct and separate unit, and no transitions between pegmatites and gold quartz veins have been found.

\section{PRODUCTION}

Undoubtedly the disintegration of the gold quartz veins has contributed a considerable amount of the coarser free gold to many of the placer deposits. This part of the production has been considerable but is difficult to estimate, for younger veins have also yielded much placer gold. 'The gold occurs in small shoots, and few of these pre-Cambrian veins have been worked continuously and profitably. Many of them are certainly poor. The Richinbar mine, in Agua Fria Canyon, has perhaps yielded more than any other deposit. The Cherry Creek veins, including the Monarch, have contributed some, and the Mesa vein, on upper Bigbug Creek, was a noted producer. Many others have been worked intermittently, at first by arrastres using the ores in the oxidized zone, which were richer owing to the setting free of the fine gold in the sulphides through decomposition by surface waters. Silver is present besides gold.

The total production from these veins in this region has probably not exceeded $\$ 1,000,000$.

\section{DISTRIBUTION}

In the Jerome quadrangle these veins occur north of Lonesome Valley ("Peters silver mine"), in the Coyote Hills in the same valley (p. 102), in the Cherry Creek district (p. 103), and east of Prescott in the southern foothills of Lonesome Valley (p. 108). In the Bradshaw Mountains quadrangle they are present at the Mesa mine, near the head of Bigbug Creek (p. 136); at the Ruth mine, on the Jersey 
Lily road (p. 116); at the Jersey Lily mine (p. 117); on the divide between Black Canyon and Bumblebee Creek; along the road to Canyon, south of Bumblebee; at the Richinbar mine (p. 157); at the Button and Boaz mine, south of Minnehaha Flat (p. 177); and at the Lehman mine, north of Copperopolis. With few exceptions, the veins are not scattered, are not contained in any particular rock, and do not form continuous belts, except perhaps at Cherry Creek.

\section{STRIKE, DIP, AND THICKNESS ,}

The strike and dip of these veins are irregular; probably the most common attitude is a northerly strike and steep dip. The Cherry Creek deposits generally dip at moderate angles to the west. The quartz occurs in lenticular shoots with a maximum width of 10 or 15 feet, usually much less. The country rock next to the veins is in places sheared, as at the Ruth mine (p. 116).

\section{MINERAIIZATION}

The principal features of the mineralization have already been mentioned. There seem to be two classes of deposits-one with bunches and pockets of free coarse gold and another in which the principal value lies in the sulphides, which carry finely disseminated gold. Generally some cyanide process has been applied after the workings have descended below the water level. The ores, aside from rich bunches of free gold, generally average below $\$ 20$ a ton in value. Some of the Cherry Creek mines, for instance, in 1909 yielded amalgamating ore averaging 1 ounce in gold and about half an ounce in silver to the ton, besides 200 pounds of concentrates that contained 40 ounces in gold and 115 ounces in silver to the ton. In other years the ore produced would average about $\$ 12$ a ton. The principal difficulty appears to be the small size and irregularity of the shoots. The tourmaline is locally abundant, as in the deposits at the Ruth mine and east of Prescott on the road to Dewey. But more commonly the tourmaline occurs as very fine-grained black streaks in the quartz which can be identified only under the microscope. With a hand lens they look like streaks of chlorite. The wall rock is rarely extensively altered to sericite. Siderite and ankerite occur in smaller amounts.

\section{UNUSUAL TYPES OF PRE-CAMBRIAN VEINS}

In the Black Hills are found several veins that differ markedly from those just described. They are represented by the Shea mine (p. 92), the Brindle Pup and Mingus Mountain mines (p. 100), the Yaeger mine (p. 98), and the Shylock deposit (p. 99). It can 
not be doubted that these veins are of pre-Cambrian age, for the absence of any kind of mineralization in the near-by Paleozoic strata is striking. They strike in an easterly direction and generally dip south or southeast at angles of $40^{\circ}$ to $60^{\circ}$. The width reaches 10 feet, and the ore occurs in lenticular masses. Most of the veins carry argentiferous tetrahedrite or tennantite, some of it containing 100 ounces of silver to the ton. The quartz is coarse and massive; there is always some siderite or ankerite and sulphides like arsenopyrite, pyrite, zinc blende, galena, and bornite, in places rudely banded but nowhere crustified.

In the Yaeger mine there are also some calcite, hematite, chlorite, and epidote, though the epidote may not be directly connected with the mineralization. The country rock may be granite, granite porphyry, diorite, or greenstone schist. Close to the vein the Shea mine at least shows marked sericitization. Possibly this mineralization had some genetic connection with the diorite intrusions. At any rate it was later than the granite and pre-Paleozoic.

The Yaeger mine, in the western foothills of the Black Hills, is easily the most prominent. The deposit contained an extensive shoot of high-grade bornite ore, with some secondary chalcocite and oxidized copper minerals, and it is said to have yielded about $\$ 1,000,000$ in copper, $\$ 50,000$ in gold, and $\$ 77,000$ in silver, which is more than can be credited to any other pre-Cambrian deposit outside of the pyritic replacement group represented by the United Verde, United Verde Extension, Blue Bell, and others.

In the Bradshaw Mountains quadrangle there are some veins probably also of pre-Cambrian age that differ markedly from the ordinary type. Like the examples from the Black Hills above mentioned they carry silver, though not invariably copper. The most prominent examples of this class are the veins in the Blue Dick, Mark Twain, and Buzzard mines, in the Hassayampa district(p. 117). -It is indeed not certain that these veins are of pre-Cambrian age, though the massive quartz, which under the microscope proves to be greatly crushed and deformed, points strongly to such a conclusion. The veins strike north and dip east and are contained in a dull greenstone. 'They carry quartz with much arsenopyrite, minor amounts of other simple sulphides, and locally also tetrahedrite rich in silver. The oxidized ore was very rich, and the Blue Dick deposit has produced ore to a value of at least $\$ 200,000$. The Dunkirk deposit, close by (p. 119), may belong to the same group; the Jersey Lily, some distance toward the west, is a pre-Cambrian gold-quartz deposit.

Among the pre-Cambrian deposits should also be classed the massive siderite, pyrite, magnetite, and chalcopyrite ore that occurs on 
the Fairview claim, on the trail from Crown King to the Peck district. A similar ore was observed at the Blue Bird mine, on the old road between the two districts. I believe that these siderite ores form lenticular masses in the schist. Little is known regarding the extent of the deposits.

\section{LATER GOLD AND SILVER VEINS}

\section{GENERAL FEATURES}

Besides the certainly pre-Cambrian quartz veins and pyritic replacement deposits there are in this region a great number of other quartz veins that carry chiefly gold or chiefly silver or considerable quantities of both metals. They are widely scattered in the Bradshaw Mountains quadrangle but absent from the Jerome quadrangle, except for some small veins in schist on the road from Prescott to Walker. In the Bradshaw Mountains quadrangle they are absent from the eastern half, but in the western part they begin near the southern boundary, in the Tiptop, Humbug, and Copperopolis districts, and continue after a short interval northward through the Crown King, Turkey Creek, Bigbug, Walker, Groom Creek, and Hassayampa districts, nearly to the north boundary line. The veins in the Hassayampa district continue beyond the western boundary and across Hassayampa River into the Congress quadrangle, ending on the north at Copper Basin. Probably they will also be found in the central part of the Congress quadrangle, about the Congress and Octave mines.

The deposits are typical fissure veins, usually straight and narrow, with well-defined walls. The strike is usually north, northeast, northwest; the veins, with few exceptions, have a steep dip. The gangue is as a rule mainly quartz of milky color and drusy structure that in places grades into well-defined comb structure. Ankerite is present in most of the veins, and barite is often found in the silver veins. Fluorite is found in three places, albite in one, adularia in one. High-temperature minerals are absent, except for magnetite and specularite, which are developed, apparently abnormally, in the Senator group in the Hassayampa district. The sulphides occur in no great volume and comprise arsenopyrite, pyrite, sphalerite, chalcopyrite, galena, commonly tetrahedrite, and less commonly ruby :silver; in the Tiptop district wolframite occurs as the earliest mineral. Sericitization and carbonatization of the country rock is the rule. The base metals are of little value except as by-products. Free gold is present in the oxidized zone, together with native silver, argentite, and occasionally ruby silver, with more or less of the chloride or bromide of silver. In the primary ore free gold is probably everywhere present, but more commonlv in intimate and micro- 
scopic intergrowth with the sulphides than as visible particles, so that of late years the cyanide process has usually been employed in the treatment. The galena carries included grains of argentite.

It is impossible to deny that all these veins are very closely related in origin, irrespective of their varying contents in gold or silver. Their structure and mineral composition point clearly to their being a product of the intermediate zone, though in one or two places there may be indications of higher temperature and though a few of the deposits approach in character those formed near the surface.

In the main they certainly bear the characteristics of dêposits of the mesothermal (intermediate) zone, ${ }^{21}$ formed by thermal solutions ascending toward the surface. Their characteristics differ markedly from those of the veins that have been determined as having a genetic connection with the Bradshaw granite. The latter were formed long before the great pre-Cambrian erosion and the development of the pre-Cambrian peneplain. There is no direct evidence of the age of the later veins, for in the region where they abound there are no Paleozoic rocks.

Three groups of these veins-those in the Groom Creek, Walker, and Crown King areas-are very clearly related areally to the small granodiorite intrusions described above, as has already been pointed out by Jaggar and Palache. However, there are many districts far distant from these areas in which this vein type is developed as characteristically. The veins are found in granodiorite, in granite, or in Yavapai schist of any type.

A few of the veins follow basic lamprophyric dikes-for example, the Mount Union and Crooks veins-but this is evidently exceptional. The one rock that is universally present is rhyolite porphyry (p. 22), in dikes that range from a few feet to 200 feet in thickness. These dikes accompany the mineralized rock in all districts and traverse the whole western part of the quadrangle, beginning near Copperopolis and continuing northward, some short, some traceable for miles with a general northerly or northeasterly trend. It has already been explained that these dikes were in all probability intruded. after the development of the pre-Cambrian peneplain, which is not likely to have been more than 500 or 1,000 feet above the present highest points in the quadrangle. If we add a scant 2,000 feet for the Paleozoic cover it is fair to conclude that these veins were formed under 3,000 or 4,000 feet of rocks, at most. The dikes described are surely earlier than the late Tertiary volcanic rocks in the region, and they are here regarded as probably late Mesozoic or early Tertiary. What part the granodiorite has played in the later mineralization

${ }^{21}$ Lindgren, Waldemar, A suggestion for the terminology of certain mineral deposits: Econ. Geology, vol. 17, pp. 292-294, 1922. 
may be left undecided. This rock also is here regarded as Mesozoic or early Tertiary but of a decidedly earlier epoch than the rhyolite porphyries, which cut the rocks of every other type except the Tertiary lava.

This remarkable system of dikes, without the presence of larger intrusive masses of the same type, stands unique, at least in my experience, in its clearly manifested genetic connection with an important system of veins. Almost all the dikes are strongly sericitized, and many of them are impregnated with pyrite and a little calcite or dolomite.

Jaggar and Palache estimated the total production of the deposits in the Bradshaw Mountains quadrangle to the end of 1901 to be $\$ 9,500,000$, and almost the whole of this sum was derived from the later quartz veins. At that time the pyritic replacement deposits had not been worked extensively, and a scant million dollars is a liberal estimate for the pre-Cambrian deposits in this quadrangle. I think that the estimate referred to is too moderate and that the actual figures are almost twice as large as the amount indicated.

The silver veins, the gold veins, and those containing both gold and silver are not separated in distinct areas. There seem to be all kinds of transitions between them, and it looks as if they were simply phases of one mineralization.

\section{SILVER VEINS}

The silver veins are widely scattered. They occur in the Hassayampa, Bigbug, Peck, Black Canyon, Turkey Creek, Tiger, Pine Grove, and Tiptop districts.

The silver veins may be divided into those containing mainly ankerite or allied carbonates and barite as gangue, with more or less quartz, and those containing mainly quartz gangue. In both classes the oxidized zone has yielded most of the ore.

\section{- VEINS WITH BARITE}

The veins of the first class are poor in pyrite but contain galena, sphalerite, and tetrahedrite. The structure is crustified with many vugs, but the minerals are fairly coarse in texture. Ankerite or siderite usually appears next to the walls and the sulphides in the center. The galena contains inclusions of argentite and the tetrahedrite is everywhere argentiferous. Ruby silver (pyrargyrite) occurs more rarely and is in many places probably supergene. The most common supergene and enriching minerals are argentite, cerargyrite, bromyrite, and native silver, besides oxidized copper and lead minerals. In most of the deposits the rich oxidized zone has been mined and work was suspended when it reached the water level 
or, at a short distance below this level, the primary sulphides. How ever, from the Arizona National and the Black Canyon veins much sulphide ore, perhaps enriched to some degree, has been shipped. The rich oxidized ores have been amalgamated or cyanided; the sulphide ore is shipped crude or concentrated. Much of the oxidized ore carried $\$ 50$ to $\$ 100$ to the ton. The primary ores are much. poorer.

Among the notable mines on deposits of this type are the Silver Belt, Arizona National, and adjacent properties in the Bigbug district (p. 128) ; the Peck and Swastika, in the Peck district (pp. 161162); the N. C. 4, in the Hassayampa district (p. 117); and the: Tuscumbia, in the Bradshaw district (p. 176). Dikes of rhyolite. porphyry occur in all the districts. They are abundant near the. N. C. 4 and Peck mines.

\section{VEINS MAINIY WITH QUARTZ GANGUE}

'The silver-quartz veins are narrow, with comb structure or drusy' quartz and in places some ankeritic carbonates. They contain more pyrite than the barite veins, also a little chalcopyrite, rarely tetrahedrite. Here and there a comb of quartz crystals coats the walls.

Among these veins may be mentioned that worked in the Tiger mine (p. 172), in the district of the same name. It is contained in granodiorite. Here the quartz attains a width of several feet and it is less drusy than elsewhere. The sulphides are sparse and comprise pyrite, sphalerite, galena, and tetrahedrite. The oxidized ore was very rich, much of it containing $\$ 100$ to the ton. Deeper and poorer ore, said to have yielded 0.07 ounce of gold and 22 ounces of silver to the ton, was mined in 1910. In depth the ore appears to be of decidedly lower grade.

East of the Tiger is the Gray Eagle lode, which in its southern part contains much gold, but its northerly extension carries more silver. Oxidized ores enriched by horn silver and argentite were shipped in 1922. One lot of 2 tons contained $\$ 2$ in gold and 454 ounces of silver to the ton and 15 per cent of lead (p. 175).

The Tiptop vein (p. 180) is another old-time producer of somewhat. unusual type. It is at most 6 feet wide. The quartz shows coarse comb structure near the walls but is finer grained in some parts, and the druses are coated with chalcedony. The scanty ore minerals consist of wolframite (earliest and along the walls), arsenopyrits, pyrite, sphalerite, bornite, and galena, formed in the order given. Here too the oxidized ore was very rich, and work was stopped at. the 800 -foot level.

There remain to be mentioned the flat veins of the Black Canyon district, not far from Turkey Creek station. These narrow veins dip. $20^{\circ}$ to $35^{\circ}$ in any direction and usually are contained in Yavapai 
schist. The Thunderbolt and the Howard Silver are the principal producers (p. 158). The War Eagle, Bueno, Goodwin, and Morgan veins, in the Turkey Creek district, are of the same or similar type.

Rhyolite porphyry dikes occur near the Morgan mine and at the Tiptop mine.

\section{GOLD AND GOLD-SILVER VEINS}

\section{PROPORTION OF GOLD TO SILVER}

By far the greater number of veins in the Bradshaw Mountains: quadrangle are gold-silver deposits. The relative amount of each metal may vary in the same vein. The gold quartz veins properly so called are few in number. The Senator group; the Walker veins, and some of the veins of the Crown King (Pine Grove district) may be counted in this class, and even here the "free" gold, recoverable by amalgamation, probably averages only one-third of the total gold value. The Mudhole mine, in the Walker district, for instance, yielded concentrates which averaged, it is said, $\$ 70$ in gold and 5 ounces in silver to the ton and some lead. The Crown King mine, in the Pine Grove district, has ore reported to average $\$ 10$ in gold and 4 ounces of silver to the ton, though some of it was much richer in gold. The McCabe ore (Bigbug district) carried about 1 ounce of gold and 10 ounces of silver to the ton.

By weight silver always greatly exceeds the gold in the ore; by value either gold or silver may predominate. Copper, lead, and zinc have been recovered as by-products in the concentrates from many mines.

It has already been pointed out that the gold in the silver veins may vary considerably along a single vein. In the same way the mineralization may vary, silver being succeeded by gold. For instance, the gold veins of the Humbug district appear to have had essentially the same origin as the silver veins of the adjacent Tiptop district.

\section{ASSOCIATED ROCKS}

The veins appear in the Yavapai schist and more rarely in the Bradshaw granite. In the Walker and Pine Grove districts they occur in granodiorite, and these veins appear to contain more gold than others. Dikes of rhyolite porphyry are found in almost all the districts. They are abundant in the Hassayampa district, especially about the Senator, Tillie Starbuck, Venezia, and Mount Union mines. They are likewise abundant in the lower Walker district, in the Bigbug district in the western part of the Pine Grove district, in the northern part of the Black Canyon district, and in the Tiptop, Humbug, and Castle Creek districts. Some of the veins follow the porphyry, as in the Mudhole and Starlight mines, but the only 
consistent connection is that the dikes occur in the same vicinity as the veins. The dikes and the veins have in the main the same strike-that is, north-northeast.

\section{MINERALIZATION}

The general type of mineralization has already been indicated. Drusy structure or comb structure of milky quartz with later carbonates is the general rule. After the first quartz deposition the sulphides followed in order-arsenopyrite (oldest), pyrite, chalcopyrite, sphalerite, galena, and tetrahedrite. The gold is usually associated with the two oldest sulphides, the silver with the two youngest. The gold is rarely in visible form. Druses in the center of the veins may be filled by ankerite or similar carbonates. The silver is contained chemically bound in the tetrahedrite and in part also in the galena; inclusions of argentite are always found in richer galena.

The structure of the vein is usually banded, but does not have the delicate concentric banding of the epithermal deposits (formed near the surface).

The alteration of the country rock tended to develop sericite and carbonates but rarely extended far from the vein.

\section{DISTRIBUTION}

The veins appear in the northwest corner of the Bradshaw Mountains quadrangle and continue outside of it in the Copper Basin district and west of Hassayampa River, coming to an end in the Thumb Butte district, a few miles west of Prescott. At Copper Basin there is a special type of copper mineralization connected with granite porphyry, and the smaller veins are mostly silver veins (p. 27).

Beginning at the northwest, the Groom Creek district, south of Prescott, is the first district of importance in the Bradshaw Mountains quadrangle. Here the narrow quartz veins carry gold and silver but little native gold. The strike is north-northeast, parallel to porphyry dikes. The country rock is Yavapai schist between two areas of granodiorite. Next south is the Walker district, in which narrow veins containing principally gold occur in granodiorite and strike northeast. These veins are continued farther southwest by the Senator-Cash-Storm Cloud.vein system, on the upper Hassayampa, which is remarkable for carrying magnetite and specularite and which is also rich in gold.

South of the Senator group near Venezia post office are two prominent veins, the Crook and the Mount Union, both gold-silver veins intimately connected with rhyolite porphyry dikes. They have a northerly strike. 
The next important vein system extends from the Silver Belt and McCabe mines southwestward toward Providence and Poland. The transition of silver veins to gold veins is well illustrated here. Many porphyry dikes run parallel to the veins.

Markedly different from this system are the Henrietta veins, with a northerly strike, which carry much chalcopyrite in the quartz and small amounts of gold and silver.

The veins in the Turkey Creek and Bradshaw districts strike more nearly north but are mainly silver reins.

The next noteworthy vein system is that extending from the Peck mine through the Pine Grove and Tiger districts (Crown King) for 10 miles southward. It is the most persistent vein system of the quadrangle and is followed with equal persistence by parallel dikes of rhyolite porphyry. The system begins at the north as silver veins, but gold increases southward to the Wildflower, Del Pasco, and Crown King vein complexes. In the southern part, in the Tiger and Gray Eagle systems, silver reappears: in large amounts. Close to the last-named veins the porphyry dikes. are apparently not present, as the main dike system courses a mile or two westward. The quartz veins are typical and strike northnortheast in the northern part of the district and nearly north in the southern part. The dip is here, as elsewhere, generally west or westnorthwest at steep angles.

A series of smaller veins appear in the northern part of the Black Canyon district, southeast of Turkey Creek station. These veins are very flat, and many show marked comb structure. 'They contain silver only in the south, in Black Canyon, but change to gold-silver veins farther north, in the Silver Cord and the veins of the "gold belt." Porphyry dikes are present.

There remain to be mentioned the gold quartz veins in the Humbug district, just west of Tiptop, where silver prevails. Porphyry . dikes are abundant, but there is no granodiorite.

On the whole there are three or four distinct vein systems with a north-northeast to northeast direction; there are also some veins that trend north. The dip is generally toward the west or westnorthwest. Only in the Walker-Senator system do steep eastward dips appear.

\section{ORE SHOOTS}

The shoots of oxidized ore, which have been mined extensively, give little information as to the attitude of the primary shoots, for they are likely to extend in a horizontal direction over widerspaces than those occupied by the unaltered ores. Such information as is available indicates that the pitch of the shoots is usually to the north or northeast át angles of about $45^{\circ}$ to $60^{\circ}$. Only in 
the McCabe and Mount Union mines, in the Bigbug district and in the Senator mine, is there some evidence of southward or southwestward pitching shoots. The shoots are generally short, few of them exceeding 200 feet in length.

\section{UNUSUAL TYPES}

Among the unusual types of vein formation the Senator-CashStorm Cloud veins stand out. Although otherwise conforming to the type here discussed, they contain magnetite, in large part altered to specularite, the plates of which project through the other sulphides. The succession seems to be pyrite (oldest), magnetite, specularite, chalcopyrite, sphalerite, and galena. The specularite is shown in Plate 14, A. (See also fig. 7.) It is said that in the Senator mine ore of this type contained much free gold. It is evident that this vein system exhibits two phases of ore deposition. In the older phase pyrite, magnetite, specularite, and chalcopyrite were deposited; in the younger phase pyrite, sphalerite, and galena.

The succession of minerals is well shown in specimens from the Cash mine. The country rock next to the ore, probably a schist, has here been altered to quartz and adularia, the latter in short prismatic crystals. The altered rock also contains calcite, ankerite, chlorite, pyrite, magnetite, and apatite in confused textures. There is some residuary albite and probably also some secondary albite. The structure of the ore is further discussed on pages 121-122.

The copper deposit of the Springfield mine, in the Crown King district, is contained in a mass of granite porphyry allied to the rhyolite porphyry. It contains only a small amount of gold. It is of interest because of its great similarity to the larger deposits at Copper Basin, in the Congress quadrangle. There are small gash veins of quartz and chalcopyrite, and the porphyry has been replaced in the vicinity to a coarse albite aggregate, with some fluorite, exactly as at Copper Basin.

The gold-bearing veins in the Castle Creek district are quartz veins in granite or schist which have suffered deep oxidation. The specularite is distinctly secondary and embedded as platy sheaves and bunches in the chrysocolla ( $\mathrm{pl} .15, A$ ). The primary ore contains much chalcopyrite, but gold is present in fair amounts. There is also, as in the Swallow mine in the adjacent Congress quadrangle, some fluorite and bismuthinite. I am uncertain regarding the origin of these veins. There is no granodiorite and few dikes close by, but the veins suggest by their appearance a comparatively late origin. 


\section{WATER LEVEL AND OXIDATION}

Throughout this mining region the water level is irregular and rather deep, ranging from 80 to 400 feet below the surface, except in the valleys with permanent water, where, of course, it does not lie so deep. In the Iron King mine (Bigbug district) the water table stands at 140 feet below the surface; in the Binghampton (Agua Fria district) at 80 feet; in the Blue Bell at 400 feet; in the Tiptop. (Tiptop district) at 400 feet; in the Cumberland ('Turkey Creek district) at 90 feet; and in the Halfmoon (Agua Fria district) at 300 feet.

The water below the water table is small in quantity, and much of it is distributed in pockets. The Blue Bell mine, in which the depth is 1,200 feet and the workings extensive, pumps 100 gallons a minute. The Sheldon mine pumps 33 gallons a minute from 600 feet. The United Verde, 2,500 feet deep, derives only 52 gallons a minute from very extensive workings. The Yaeger mine at 1,300 feet made 14. gallons a minute. That the water tends to diminish with increasing depth is clearly shown in the deep mines at Jerome.

In an area like this, with irregular water level and scant supply, it is not surprising that the limit between oxidized and primary ore may be indefinite. Residual sulphides may be found close to the surface, and in places oxidation reaches below the water level and gradually fades out. Chalcocite, covellite, and argentite may be found high up in the oxidized zone wherever some primary sulphides are preserved.

An example of the replacement of sphalerite by argentite 75 feet below the surface is shown in Plate 14, $B$. In most places there is no chalcocite zone proper or only a thin layer of enriched material.

The oxidized 'zone is thus from 100 to 400 feet thick. As a rule the zone is rich in gold and silver, except that the silver may be leached for a short distance below the surface. In many of the silver veins the oxidized zone was extremely rich, the ore ranging from $\$ 50$ to $\$ 400$ a ton and containing cerargyrite, bromyrite, argentite, and in all probability secondary ruby silver. This content was usually found to contrast with poverty of the underlying primary ore, which may contain only $\$ 8$ to $\$ 10$ a ton. In the gold veins a similar concentration has taken place, but with considerable less intensity, enriched ore with $\$ 20$ to $\$ 50$ a ton contrasting with much poorer primary ore.

All this is explained by the fact that erosion has been progressing steadily in the region ever since the Paleozoic beds were first stripped from the underlying pre-Cambrian rocks. It has not been progressing with extreme rapidity and has been checked at intervals by raising of the base-level (by lava flows, for instance). At times 
in the Verde district it has been quickened by faulting or by lowering: of the base-level.

The remarkable silver enrichment speaks for a long-continued' accumulation from portions of the veins now eroded. If the oxidized zone is several times as rich as the primary ore, this indicates: an erosion of at least several times the depth of the present oxidized zone. The compact rocks would minimize the lateral scattering of the silver solutions.

Gold has been less enriched, it is believed, because its downward transportation by solutions has been far less marked. Successive erosion scattered the gold over the surface. The gold in the oxidized zone is easily recoverable by amalgamation, for to the free gold of primary origin was added the invisible gold in the sulphides, set free by decomposition and segregated to visible particles.

\section{CHALCOCITE ZONES}

The conditions of erosion, climate, and water level have not been favorable in this region for the development of a chalcocite zone in copper deposits. Erosion has run too close on the heels of disintegration and descending solutions. Chalcocite may be found at any place above the water level where fresh primary sulphides happen to remain, and massive chalcocite appears at the very top of Copper Mountain in silicified schist, though oxidized ore occurs much lower down.

In the Bradshaw Mountains quadrangle none of the copper mines have disclosed a supergene sulphide zone. In the Blue Bell oxidation extends to a depth of 400 or 500 feet, and chalcocite may be found in places in the lower part of that zone. There is no chalcocite zone in the De Soto and Binghampton mines. In places a thin concentration of copper sulphides, with an enrichment of gold and silver, appears close to the water level-for instance, in the Iron King mine (p. 127).

In the Jerome quadrangle similar conditions exist. The deposits lie mostly on a steep slope exposed to rapid erosion and oxidation. The whole of the United Verde deposit is really now exposed to oxidizing conditions.

In the Copper Chief mine there is a deep oxidized zone which, considerably above the present water level, is underlain by a chalcocite zone only a few feet thick and with greater silver than copper concentration. The United Verde deposit, which crops out at an altitude of 5,500 feet, has an oxidized zone 200 feet deep, though partial oxidation and scattered chalcocitization. have proceeded to the 500 or 600 foot level. 
These are the conditions prevailing since the pre-Cambrian was exposed below the Paleozoic beds that once covered it.

Before this time, during the development of the pre-Cambrian peneplain, the conditions for the development of a deep chalcocite zone were ideal-deep water level, hot climate, flat relief, and extremely slow erosion. The Copper Chief and United Verde deposits now exposed below the pre-Cambrian peneplain, had doubtless both extremely rich chalcocite zones many hundreds of feet in depth. These zones have been rapidly destroyed since the exposure of the pre-Cambrian and there is little left of them now.

Fortunately, one of these pre-Cambrian chalcocite zones-that in the United Verde Extension mine-has been preserved underneath the sedimentary cover to the east of the Verde fault. A description is given on page 84, and it is sufficient to say here that the deposit is one of the largest masses of chalcocite known. The surface later covered by the Cambrian sea was deeply and completely leached of copper down to a depth of about 300 or 400 feet, though in places outside of the main ore body there may be some residual chalcocite nearer to the surface. The chalcocite zone descended at least 400 feet, perhaps 600 feet, below its top-that is, at least 800 feet below the pre-Cambrian peneplain. The old, now destroyed, chalcocite zone of the United Verde had a depth of 700 feet below the same level and the chalcocite body itself was probably 400 feet deep.

\section{PERSISTENCE IN DEPTH}

The subject of persistence in depth of an ore deposit is assuredly not easy to discuss; nevertheless it must be approached. I think it may be regarded as proved that all the veins and replacement .deposits in the region were formed by solutions which were ascending from igneous bodies far below the present surface and from which, owing to a disturbed equilibrium, certain more or less volatile constituents were being eliminated. These solutions may not have ascended straight upward. Their pathway may indeed have been very irregular, jumping sideways or even locally downward. - Therefore, although it is concluded that the mineralization continued far below present levels, it may not have followed down every little fissure in which the deposits now occur.

That the solutions were probably for the most part under heavy pressure from below is shown by the way in which the replacement spread and the fissures were kept open. Regarding their physical nature we know little. The pre-Cambrian quartz veins were probably very rich in silica but carried some carbon dioxide, boron, and other mineralizers. They were deposited by the granitic juices pressed out from the parent magma. These veins may continue be- 
yond our ken, but their ore shoots are small and irregular, and it is doubtful whether they will pay for mining in depth.

The origin of the pyritic replacement deposits has been discussed on page 35. One of these deposits goes down as a gigantic pipe to a depth of 2,500 feet and probably continues below this depth. What its total length was above the present bottom can not be determined, but it must have been more than 4,000 feet. Within the portion now known there is practically no filling of open spaces; simply a replacement by sulphide, quartz, carbonates, and chlorite, effected by solutions rising through and penetrating this pipe, whose position was most probably determined by the intersection of several fractures. Nothing but solutions, perhaps concentrated but assuredly very mobile, subject to diffusion and osmotic action, could have formed this deposit. To talk about an "ore magma" in such a case is to play with words.

Some of these pyritic replacement deposits, then, go down to great depths. But it can not be denied that some of them tend to assume a funnel-like shape or a form of tapering lenses, and it is: believed that this tendency, which has led to the abandonment of some deposits, points to lateral movement of the ore solutions. In the larger deposits the bodies richer in copper form shoots or lenses: in the more abundant pyrite, the lenses generally following the schistosity of the rock. In places the grade of the ore in the deposit runs: perilously close to the lowest permissible limit, but I do not think that anywhere a gradual fading of value takes place in depth.

It is quite possible that new pyritic replacement deposits will be discovered. Prospecting for them is expensive, however.

Lastly we have to consider the later (Mesozoic?) gold and silver veins. Their drusy and crustified structure has been described sufficiently above, and the conclusion has. been adopted that they were deposited by solutions ascending from a rhyolitic magma, which also furnished the material for the numberless dikes of the region. In their typical development they show more or less sericitized and carbonatized walls, poor in gold and silver, and a filling consisting. of a deposit of long, slender quartz crystals projecting inward into: a mass of mixed sulphides molded on the crystal points. In the center are drusy masses of ankerite, dolomite, or calcite. Or the whole vein may consist of such granular ankerite or dolomite with. druses of thin barite plates and bands of coarse sulphides.

Does this picture look like crystallization from an injecting magma? The diffusion of the aqueous and gaseous parts of the solution into the rock and the retention of its other constituents in the fissures are entirely like phenomena that we observe close to thesurface and that were assuredly produced by very mobile aqueous solutions. 
Now, it is certainly a fact that much of the oxidized ore was rich; also that in a great number of mines the mining operations ceased when the limit of the oxidized ores was reached-for instance, the Henrietta, Silver Belt, Tiptop, Tiger, Crook, and Peck. The primary ore proved to be at least close to the limit of the local definition of ore. Certainly this does not prove that richer ore does not occur in shoots in the generally low-grade primary ore, nor that -working conditions can not be improved and processes cheapened so that many ores now unavailable may be used. More or less oxidized ore may remain, but the great bulk of it has been mined. For permanency the primary ore must be relied on.

It is also true that in many mines this primary ore has proved profitable. The McCabe mine has yielded a large production from arsenical gold ores. The Senator has been worked to a depth of 600 feet; in the Cash mine similar primary ore has been extracted successfully. The Crown King mine contained shoots of rich and medium-grade ore below water level. The Sheldon mine has recently produced good gold ore below the oxidized zone, as the Mudhole did some years ago.

Many mines have doubtless been closed because of wasteful and illadvised operation. It would be rash indeed to condemn a region because every deposit did not carry ore shoots of the first order.

Ore will no doubt be mined in the Bradshaw Mountains for a long time to come, but the generally narrow veins and low-grade ores will require good judgment and technical skill.

\section{PLACER DEPOSITS}

The mining industry in Yavapai County began by the discovery of placers in 1863. For a short time they yielded well, and, indeed, they are not yet wholly exhausted. A few thousand dollars' worth of placer gold is still produced in the county each year.

The deposits are almost wholly confined to Quaternary gravel along the present streams. It is true that some Tertiary gravel intercalated in the volcanic flows along the western boundary of Bradshaw Mountains quadrangle contains a little gold, but attempts to work it have not been successful.

Gold-bearing gravel was found all along Hassayampa River, almost up to its headwaters. The generally fine gold in this gravel was derived from the erosion of both pre-Cambrian and later veins. Little or no work is now done on the upper Hassayampa.

Lynx Creek, which heads in the Walker district, was the richest stream in the region. The district contains a great number of postCambrian veins, and their disintegration set free large amounts of fine gold, which has been mined all along the creek for many miles 
below Walker. Some placer gold is still recovered here annually (say $\$ 1,000$ ), and the total output is estimated at $\$ 1,000,000$, a small sum compared to the yield from other famous camps. It is stated on good authority that there is some comparatively shallow dredging ground on the lower Lynx Creek. If this statement is correct, it is probably the only deposit of its kind in the region.

Placer gravel has been worked in Minnehaha Flat and on Grove Creek; on Chaparral Gulch and the adjoining ravines, near McCabe; in Bigbug Creek as far down as Mayer; in Black Canyon from the vicinity of Turkey Creek station to the junction of Turkey Creek with Agua Fria River; in several gulches of the Humbug district, near the south border of the quadrangle; and in Castle Creek, in ravines near Copperopolis.

No single class of primary deposits forms the source of the placer gold, but the pre-Cambrian veins, which carry coarse free gold, added to the contents of the gravel at many places. The fine gold comes in large part from the oxidation of the gold contained in very fine form in the sulphides of the post-Cambrian veins.

A little placer gold has been mined at Del Rio, in the Jerome quadrangle, but on the whole, except on the lower Lynx Creek, that area is barren of deposits of gold-bearing gravel.

\section{DETAILED DESCRIPTIONS}

\section{VERDE DISTRICT ${ }^{23}$}

\section{SITUATION}

The Verde district is the most important mining center in the region here described, for it contains two mines of unusual richness, the United Verde and the United Verde Extension. It lies on the eastern slope of the Black Hills, extends north-northwest, and occupies an area about 7 miles long and 3 miles wide. This area lies about parallel to the broad valley of Verde River. The principal town is Jerome, situated high on the eastward-facing slope, and in the valley 2,000 feet below lie the two smelter towns of Clarkdale and Clemenceau.

\footnotetext{
${ }^{22}$ Emmons, S. F., The secondary enrichment of ore deposits : Am. Inst. Min. Eng. 'Trans., vol. 30, p. 192, 1900. Graton, L. C., IT. S. Geol. Survey Mineral Resources, 1907, pt. 1, p. 597, 1908. Ransome, F. L., in Emmons, W. H., The enrichment of sulphide ores: U. S. Geol. Survey Bull, 529, p. 192, 1913. Provot, F. A., Geological reconnaissance of the Jerome district (abstract): Eng. and Min. Jour., vol. 125, p. 1028, 1916. Finlay, J. R., 'The Jerome district of Arizona : Eng. and Min. Jour., vol. 106, pp. 557-562, 605610,1918 . Tovote, W., Certain ore deposits of the Southwest: Am. Inst. Min. and Met. Eng. 'Trans., vol. 61, p. 54, 1920, with discussion by P. D. Wilson and W. G. Mitchell. Reber, L. E., jr., Geology and ore deposits of the Jerome district: Am. Inst. Min. and Met. Eng. Trans., vol. 66, pp. 3-26, 1922.
} 


\section{GENERAL GEOLOGY}

The main geologic features are displayed on a magnificent scale. The summit of the Black Hills is covered by a thick flow of Tertiary basalt, which on the flat Mingus Mountain reaches an altitude of 7,720 feet, or 4,500 feet above Verde River. The basalt rests on horizontal Paleozoic limestones, here about 1,000 feet thick and having a sandstone layer at the base (Tapeats sandstone). Below the Paleozoic succession, which is barren of ore deposits, are the pre-Cambrian peneplaned rocks, which contain the metallic wealth of the district. Each of these terranes is beautifully exposed, with the surface forms characteristic of active erosion on a steeply sloping surface. The dark bluffs of the basalt flows, the pale-yellow or reddish salients of the horizontal sedimentary beds, and the rough, irregular black or brown outcrops of the old pre-Cambrian rocksall combine to present a scene of rare beauty and grandeur.

The pre-Cambrian rocks form a wedge-shaped area whose point is a short distance north of the United Verde mine-say threequarters of a mile north of Jerome-and which gradually reaches a width of 2 or 3 miles in the south end of the district. The rocks generally have a red or dark-brown color due to slight oxidation and are more or less schistose. The greatest area is formed by the greenstone complex described below, but intrusive in this rock are smaller masses of rhyolite porphyry ("quartz porphyry") and diorite. Schistose rocks of sedimentary origin, such as jasper, quartzite, and slate, are locally embedded in the greenstone schist. The largest exposure of rhyolite porphyry is on Cleopatra Mountain, which rises west of Jerome, to an altitude of 6,052 feet. The largest mass of diorite is exposed just north of the United Verde mine.

Jerome appears perilously perched on the steepest portion of the general slope of the mountain, where the gulches become abrupt and steep-graded canyons afford admirable cross sections of the crystalline rocks, exposed by the greatest single structural feature of the district, the Verde fault, which is traceable with a northnorthwesterly direction across the whole northwestern part of the Jerome quadrangle. (See pl. 1, in pocket.) This fault is the westernmost but the best exposed of a series of faults along which the west side of the Verde Valley has been successively lifted, probably in all about 4,000 feet (p. 12). The Verde fault, by exposing the pre-Cambrian rocks has made possible the exploitation of the ore bodies. It has rejuvenated the transverse drainage and produced the striking physiographic features of the district. In the Edith shaft of the United Verde Extension mine the peneplaned preCambrian surface lies at an altitude of 4,230 feet. Above Jerome the 
same surface--at the base of the Tapeats sandstone-lies at 6,000 feet, making an approximate throw of 1,770 feet. East of the fault line the down-thrown Tertiary basalt flows of the summit of the range crop out, and below these, exposed in favorable places, are the down-thrown Paleozoic sediments. The slope below the fault is more or less covered by Quaternary gravel. In places below and above the basalt is Tertiary gravel earlier or a little later than the basalt. Thus on the down-thrown side the pre-Cambrian is deeply hidden underneath lava, gravel, and Paleozoic beds. Mining operations striving to uncover ore bodies in this down-thrown block have exposed the greenstone complex and allied rocks at many placesfor instance, in the United Verde Extension mine (fig. 6). The faulting is placed in the late Tertiary or early Quaternary; after the faulting the deep trough of the Verde Valley was deeply filled with limestone débris, forming the soft lake beds of the Verde formation, now exposed all along the lower slopes of the valley.

\section{PRE-CAMARIAN ROCKS}

The pre-Cambrian at Jerome corresponds to the Yavapai schist of the Bradshaw Mountains, though it shows a slightly different facies. In places the schistosity is less well marked and varies in direction, and the sediments are less in volume, but in the main it is the same series of rocks.

The bedded sediments comprise quartzite, banded jasper, and slate. They are highly altered and are evidently older than any of the other rocks, for they lie inclosed in the greenstone complex in small patches and irregular areas. The beds can not be followed far and have a steep dip. The largest area is found near the United Verde mine. Reber ${ }^{23}$ mentions a small lens of limestone and a tuffaceous conglomerate belonging to the same series.

The greenstone complex comprises greenish-gray, generally schistose rocks, which strike from north-northwest to west. The common feature of the greenstone is the finely disseminated chlorite; only rarely is any definite texture visible. In general, I believe these rocks to be supracrustal - that is, they originally formed lava flows, tuffs, and agglomerates. In places this ancient structure is still visible, as in Yaeger Canyon and Mescal Gulch. The beds of finer and coarser agglomerates dip about $45^{\circ}$ north or west, and the schistosity is superimposed. Some, but not all, of the greenstones are of basic nature; part of the material was more or less acidic, as in Deception Gulch. ${ }^{24}$

\footnotetext{
${ }^{23}$ Reber, L. E., jr., Geology and ore deposits of the Jerome district: Am.. Inst. Min. and Met. Eng. Trans., vol. 66, pp. 3-26, 1922.

24 Finlay, J. R., The Jerome district of Arizona : Eng. and Min. Jour., Sept. 28 and Oct. 5, 1918. Benedict, P. C., The geology of Deception Gulch and the Verde Central mine (unpublished thesis, Massachusetts Inst. Technology, 1923).
} 
The greenstones mainly contain fine-grained chlorite, sericite, and quartz; rarely are there any feldspar phenocrysts left unaltered. At Deception Gulch the greenstone schist is a "quartz porphyry." with typical phenocrysts of quartz, though it is distinctly earlier than the normal intrusive "quartz porphyry" of the district.

The "quartz porphyry" or rhyolite porphyry forms a large area south of the United Verde mine, including Cleopatra Mountain, where it is intrusive into the greenstone complex. Good exposures are found along the new Prescott road. Many dikes of rhyolite porphyry occur in the same complex on the east side of the fault. Dikes of the same rock are found in the southern part of the district, though, as Reber remarks, the rock is here coarser grained, going over into a fine-grained granite. The schistosity is present to a varying degree, some of the porphyry being almost massive, whereas other parts show intense schistosity. Benedict holds that the schistosity is in general parallel to the inclosing rocks.

The fresh nonschistose rock is hard and slightly greenish gray and contains abundant quartz phenocrysts from 1 to 3 millimeters in diameter. Feldspar crystals are small and indistinct. The groundmass is very fine grained. Fluidal structure is seldom seen.

Under the microscope the quartz-sericite alteration is strongly marked. Most of the phenocrysts are converted to sericite, and the groundmass is a fine-grained felt of quartz, sericite, and a little chlorite. Such feldspars as remain unaltered are albite, according to Benedict. Reber ${ }^{25}$ states that "the usual composition is that of a normal rhyolite, often an albite rhyolite and rarely a dacite." The groundmass is also variable as to size of grain, though usually fine. Benedict states that it is always finer near the contacts. Most of the rhyolite near the ore bodies in the United Verde mine is schistose, and much of it is impregnated with pyrite.

Reber believes that the rhyolite is clearly intrusive and regards it as a facies of the Bradshaw granite. It is doubtful whether this is the true correlation; this rhyolite magma was probably intruded much nearer to the surface than the main granite batholith, and I should incline to consider it a part of the Yavapai schist.

Smaller masses of diorite are intruded into the older schists. The largest of these masses is found just north of the United Verde mine and in fact forms the hanging wall of the ore body. Reber belieres that this also is a facies of the Bradshaw granite; be that as it may, it surely is one of the youngest of the pre-Cambrian rocks: The rock is dark green and of medium grain and is composed of about equal parts of augite and feldspar, with more or less of alteration products such as chlorite and epidote. Though it has suffered

${ }^{25}$ Op. cit., p. 13. 
somewhat from deformation it is rarely schistose; near the contacts a faint schistosity may be observed. Alteration has masked the true character of the feldspar; it is probably andesine or oligoclase. The alteration tended toward saussuritization-that is, to the formation of an aggregate of zoisite and albite. There was also some sericitization of the feldspars. The augite is colorless, rudely idiomorphic, and extensively altered to chlorite with much epidote and some actinolite.

The dikes, which cut through all older rocks and the ores as well, are best exposed in the United Verde mine. They are narrow, with an easterly strike and more or less nearly vertical attitude. They are in general completely decomposed, with clay gouge along the walls, and contain much secondary gypsum in veins. In places they form a clayey mass and only rarely can rocks be found which are suitable for thin sections. Reber calls them andesite dikes but a more suitable name would probably be diorite porphyry. Some of them are slightly mineralized by the introduction of disseminated pyrite or veinlets of chalcopyrite and dolomite. They are clearly later than the diorite and also later than the main ore bodies.

The freshest specimens of the dikes show now only feldspar, with much chlorite, calcite, and some sericite and "leucoxene." The feldspars are more or less clearly lathlike and are determined as andesine. No primary ferromagnesian silicates remain.

\section{PALEOZOIC SEDIMENTS ${ }^{26}$}

The Verde fault has divided the Paleozoic section near Jerome into two parts. The easterly section is poorly exposed but has been opened by mining operations at several places, notably in the workings of the United Verde Extension and Dundee mines. The westerly section is magnificently exposed on the slopes above Jerome. It lies on top of the peneplaned surface of the pre-Cambrian and is in turn covered by black Tertiary lava, which here forms the summit of the range. The white or yellowish beds lie almost horizontal, except where tilted by faulting, and have a general very slight northward dip. The lowest formation exposed is the Tapeats sandstone of Cambrian age with a maximum thickness of 80 feet. Above this lies about 500 feet of thin-bedded limestone ${ }_{\dot{x}}$ becoming sandy toward the top, in part at least of Devonian age, succeeded by 250 feet of white Redwall limestone, which is exposed in places toward the north below the lava. The thick Supai formation (Pennsylvanian and Permian) of red sandstone crops out in part

${ }^{26}$ Reber, L. E., jr., op. cit. Ransome, F. L., Some Paleozoic sections in Arizona and their correlation: U. S. Geol. Survey Prof. Paper 98, p. 161, 1916. 
below the lava west of Jerome but is beautifully exposed across the Verde Valley.

\section{TERTIARY LAVAS}

Basaltic lava, generally referred to as "malpais," covers the summits of the Black Hills west of Jerome. On Mingus Mountain it forms a considerable plateau, heavily forested with yellow pine. The maximum thickness is about 700 feet. Occasionally dike feeders of this flow are found in the limestone. Below the lava a slight recrystallization of the limestone is noted here and there. The basalt was poured out over a somewhat dissected surface, which in places was covered by well-washed prebasaltic gravel. Some of this gravel is now found on the high shoulders below the lava. Below the Verde fault it may also be observed-for instance, in Mescal Gulch, a short distance south of Jerome. Here the faulting has produced a tilting of the coarse gravel beds.

\section{TERTIARY LAKE BEDS}

The faulting which so plainly left its marks on Jerome topography and caused the great depression of the Verde Valley took place after the Tertiary flows and is assigned to Pliocene or post-Pliocene time. Damming of the Verde Valley by basalt flows produced a lake in which white calcareous sediments from the surrounding limestone hills accumulated to great depth. These lake beds, named by $O$. P. Jenkins the Verde formation, are at least 1,500 feet thick and crop out prominently on the east side of the valley and to some extent also on the west side.

Reber ${ }^{27}$ says :

The interrupted drainage of the lake period and the relief produced by faulting promoted the formation of extensive deposits of poorly sorted gravels and boulders, differing from those underlying the lava chiefly in the presence of abundant fragments and boulders of basalt. These younger gravels merge Into the margins of the lake beds in some localities. Following the restoration of normal drainage, the present channel of the Verde River and numerous tributary gulches have trenched the Verde formation and the gravel deposits.

The Verde fault is well exposed at the portal of No. 5 tunnel, United Verde mine. At this place it sharply separates limestone on the east from amphibolitic greenstone on the west. Immediately above the limestone rests prebasaltic gravel, and above this is basalt. The fault gouge, which is only about 1 foot wide, is red in the hanging wall and green in the footwall. The fault plane dips $60^{\circ} \mathrm{ESE}$.

${ }^{27}$ Reber, L. I., jr., op. cit., p. 8 . 
In the mine the fault is exposed at two places on the 500 -foot level. The gouge is here again only 1 to 2 feet wide and is stained deep red. Much crushing is in evidence in the vicinity. At one place fragments of pyrite are inclosed in the gouge.

The fault is also exposed in the United Verde Extension mine. Here it is much wider and accompanied by sheeting and drag of chalcocite ore.

\section{ORE DEPOSITS}

The whole production of the Verde district, aside from a little oxidized copper ore in Quaternary gravel and in the limestone, is derived from deposits in the pre-Cambrian terranes. Four mines have contributed to this output-the United Verde, the United Verde Extension, the Copper Chief (and Equator), and the Jerome Verde. The great bulk of the production has come from the first two. Roughly the production since 1883 amounts to $\$ 126,000,000$ in copper, $\$ 12,000,000$ in silver, and $\$ 9,000,000$ in gold, and a little zincin all about $\$ 147,000,000$. Most of this output has been produced since 1894, and much the largest part has come from the United Verde mine. Few districts can equal this record-none from so few producing mines.

The ore bodies are pyritic replacement deposits in schist, generally in rhyolite porphyry schist. Some of them are elongated along the schistosity, but the largest deposits are vertical or steep chimneys, with irregularly rounded outline. The ore minerals are pyrite and chalcopyrite, the gangue quartz, and earthy carbonates.

There are also irregular quartz veins with coarse pyrite and chalcopyrite and the same gangue minerals, but these have contributed little or nothing to the production. Through descending waters enriched zones have been formed below the pre-Cambrian peneplain, and large bodies of chalcocite of this origin have been mined, particularly in the United Verde Extension.

The deepest ore body is that of the United Verde mine, which has been followed to a depth of 2,500 feet.

There is also a third type represented by the Shea, Yaeger, and Shylock mines, the last two in an adjoining district. These deposits form well-defined fissure veins striking east and dipping south; they are really lenses of quartz which present a different type and may be of somewhat later age than the pyritic deposits. They carry in a quartz-ankerite-siderite gangue such minerals as tetrahedrite, bornite, arsenopyrite, galena, and sphalerite but have contributed comparatively little to the production.

A discussion of the origin of all these deposits will be found on pages 35,39 , and 40 . 


\section{UNITED VERDE MINE ${ }^{28}$}

\section{LOOATION}

The mine operated by the United Verde Copper Co. is situated just north of the town of Jerome, on the eastern flank of the Black Hills, at an altitude of about 5,500 feet above sea level. (See pl. 6.) The mine and the town are on a steep hillside sloping to the valley of Verde River. The smelting works are at Clarkdale, on Verde River, 4.1 miles distant in an air line from the mine and at an altitude of 3,560 feet. The two places are connected by the Verde Tunnel \& Smelter Railroad, a standard-gage line 11 miles long, almost three times the distance by air line. At Clarkdale this line connects with the Verde Valley branch of the Atchison, Topeka \& Santa Fe Railway.

The United Vercle deposit is beyond doubt the largest pyritic copper deposit in the United States and certainly one of the largest in the world. In tonnage it is exceeded by the ore body of the Utah Copper Co. at Bingham, Utah, and other more or less blanketshaped deposits that owe the origin of their low-grade ore to concentration by descending waters, but I know of no other single primary pyritic mass of ore which equals it in size and richness. The mechanical equipment of this mine is probably better than that of any other copper mine in the world.

Altogether, it merits a monograph rather than a few pages, and I am conscious that my description fails to do justice to it. Fortunately the mine and its geology have been very fully described in the two admirable papers, already cited, by L. E. Reber, jr., geologist, and by H. DeWitt Smith and W. H. Sirdevan, engineers. The following description is based on several visits to the workings under the guidance of Mr. Reber, but I have frequently borrowed from the papers mentioned, as I realize fully that their authors know the mine far better than I.

\section{HISTORY}

The history of the district is largely the history of the United Verde mine. The earliest locations in the district were made in 1876. According to Rickard: ${ }^{29}$

The claims now forming the United Verde are said to have been worked for silver between 1880 and 1885 . No silver-reduction plant, however, was

${ }^{23}$ Reber, L. E., Jr., Geology and ore deposits of the Jerome district : Am. Inst. Min. and Met. Eng. Trans., vol. 66, pp. 3-26, 1922. Smith, H. D., and Sirdevan, W. H., Mining methods and costs at the United Verde mine: Idem, pp. 127-181. Tally, R. B., Mine-fre methods employed by the United Verde Copper Co.: Idem, vol. 55, pp. 186-195, 1917. Rice, Marion, Petrographic notes from the ore deposits of Jerome, Ariz.: Idem, vol. 61, pp. 60-65, 1920. Weed, W. H., The Mines Handbook, pp. 419-423, 1922.

${ }^{20}$ Rickard, T. A., The story of the U. V. X. bonanza: Min. and Scl. Press, vol. 116, p. $9,1918$. 
erected. The ore was smelted for copper as early as 1883, when a 42-inch water-jacket furnace was erected. The president of the company that operated the United Verde at that time was F. A. Tritle, formerly governor of Arizona and still earlier the manager of the Yellow Jacket mine on the Comstock lode. The secretary and the treasurer of the company was Eugene Jerome, of New York, and it was after him that the town of Jerome was named. This company produced a considerable quantity of copper, in the form of black copper and matte, until 1887, at which time the resources of the mine appeared to be depleted. In 1889 William A. Clark, subsequently Senator from Montana, bought the property and started fresh exploratory work.

The report by H. C. Burchard, Director of the Mint, on the production of the precious metals in the United States for 1884, page 61 , contains this passage:

The mines owned by the United Verde Copper Co., at Jerome, have proved a series of surprises to the owners. The properties were purchased and worked as copper properties, but as they have been developed they are found to contain silver in large quantities-in fact, so large that the silver is sufficient to par all the running expenses of the mine, leaving the copper as a profit to the owners.

Superintendent Thomas writes that another rich strike has been made in the Wade Hampton, one of the company's mines, on a drift from the 100 -foot level 25 feet north of the last body of ore struck on the same level. The extent of it had not been ascertained, but the first samples taken assayed 20 per cent copper and rich in silver. In every direction that drifts or crosscuts have been run ore bodies have been encountered. The furnace has run up to October 1 , 1884, 289 days, and superintendent Thomas gives the product by assays at the mines 4,396,951 pounds of refined copper and 237,951 ounces of silver. Estimating the average price of copper at $\$ 250$ per ton, the gross yield of copper amounts to $\$ 548,500$, and the silver at its coining value, $\$ 1.29$ per ounce, amounts to $\$ 307,655$.

In the same report (p. 32) it is stated that the United Verde Copper Co. paid a dividend of $\$ 60,000$ in 1884 .

Rickard makes the interesting statement that Senator Clark's attention was first drawn to the mine by seeing some specimens of its ore at the New Orleans Exposition in 1884, and that a few years later he sent Joseph L. Giroux, well known in the annals of western mining, to examine the deposit. He found that Dr. James Douglas had an option, which, however, Douglas decided to let lapse because the ore was deemed "spotty." After personal inspection Senator Clark purchased the property, and it is understood that to this day he owns practically all of the stock.

It is also interesting to observe that Senator Clark, like Doctor Douglas at Bisbee, failed to recognize the full possibilities of the district, and it fell to a son of Doctor Douglas to discover the second bonanza of the district, the United Verde Extension.

The first dividend under the Clark régime was paid in 1892. 
The mine was worked under difficult conditions until 1892, as supplies had to be hauled 28 miles from the nearest railroad point. A narrow-gage railroad connecting at Jerome Junction with the Ash Fork-Prescott branch of the Santa Fe system was completed in 1894. This narrow-gage road was called the United Verde \& Pacific Railway. It was dismantled in 1919, when a broad-gage branch of the Santa Fe was built leading from Drake, a point nearer to Ash Fork, through the Verde River canyon to Verde Valley, where the new smelter had been built at the place now called Clarkdale.

\section{PRODUCTION}

The production of the property under Senator Clark began about 1890 and has been steadily increasing.

Production of United Verde Copper Co., 1900-1918

\begin{tabular}{|c|c|c|c|c|}
\hline Year & $\begin{array}{l}\text { Dry ore } \\
\text { (tons) }\end{array}$ & $\begin{array}{c}\text { Fine copper } \\
\text { (pounds) }\end{array}$ & $\begin{array}{c}\text { Silver } \\
\text { (ounces) }\end{array}$ & $\begin{array}{c}\text { Gold } \\
\text { (ounces) }\end{array}$ \\
\hline $\begin{array}{l}1900-1913 \\
19145 \\
191610 \\
1917\end{array}$ & $\begin{array}{r}3,800,232 \\
391,027 \\
491,146 \\
694,053 \\
813,176 \\
861,250\end{array}$ & $\begin{array}{l}464,394,541 \\
32,545,924 \\
45,127,832 \\
58,299,573 \\
71,726,334 \\
77,501,595\end{array}$ & $\begin{array}{r}7,242,383 \\
683,417 \\
902,881 \\
1,030,851 \\
1,223,310 \\
1,292,109\end{array}$ & $\begin{array}{r}268,152 \\
21,963 \\
28,221 \\
26,416 \\
29,230 \\
29,281\end{array}$ \\
\hline & $7,050,884$ & $749,596,099$ & $12,374,951$ & 403,263 \\
\hline
\end{tabular}

-Am. Inst. Min. and Met. Eng. Trans., vol. 66, p. 127, 1922.

From 1888 to the end of 1922 the mine has produced 1,111,971,696 pounds of copper, 563,375 ounces of gold, and 18,406,232 ounces of silver, or roughly $\$ 166,900,000$. Late production figures are withheld. The cost of making a pound of copper from United Verde ore is now distributed as follows: Labor, 3.67 cents; fuel and power, 2.03 cents; supplies, 2.64 cents; freight on bullion, 0.7 cent; refining, 1.15 cents; taxes, 1.98 cents; and depreciation, 0.5 cent. $^{200}$

The following table of recovery is taken from the paper by Smith and Sirdevan referred to above:

Recovery per ton from ore by United Verde Copper Co., 1900-1918

\begin{tabular}{|c|c|c|c|}
\hline Year & $\begin{array}{c}\text { Fine } \\
\text { copper } \\
\text { (pounds) }\end{array}$ & $\begin{array}{c}\text { Silver } \\
\text { (ounces) }\end{array}$ & $\begin{array}{c}\text { Gold } \\
\text { (ounces) }\end{array}$ \\
\hline 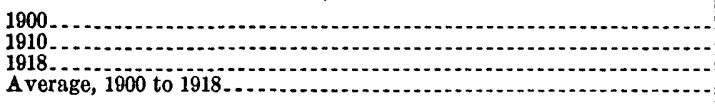 & $\begin{array}{r}162.9 \\
106.0 \\
91.0 \\
106.3\end{array}$ & $\begin{array}{l}\text { 2. } 10 \\
\text { 1. } 55 \\
\text { 1. } 50 \\
\text { 1. } 75\end{array}$ & $\begin{array}{r}0.065 \\
.058 \\
.034 \\
.057\end{array}$ \\
\hline
\end{tabular}

The approximate total ore mined to the end of 1918 was $8,200,000$ tons. Over 50 per cent of this total had been mined since 1914.

20a U. S. Geol. Survey Mineral Resources, 1923, pt. 1, p. 546, 1925.

$68508-26-6$ 
Dividends were begun in 1892 on the basis of 25 cents a share monthly. Recent dividends have been as follows:

Dividends paid by United Verde Copper Co., 1900-1924

\begin{tabular}{|c|c|c|c|c|c|}
\hline 1900 _-_----- & $\$ 4,500,000$ & 1909 & $\$ 2,700,000$ & 1918 _-------- & $\$ 5,550,000$ \\
\hline 1901 & $2,925,000$ & 1910 _ & $2,700,000$ & 1919 & $2,700,000$ \\
\hline 1902 & $2,250,000$ & 1911 _- & $2,250,000$ & 1920 & $1,800,000$ \\
\hline $1903 \ldots$ & 900,000 & 1912 & $1,800,000$ & 1921 & $1,800,000$ \\
\hline 1904 & $1,800,000$ & 1913 & $1,575,000$ & 1922 & $2,250,000$ \\
\hline 1905 _.----- & $2,025,000$ & 1914 & $1,125,000$ & 1923 & $3,450,000$ \\
\hline 1906 & $2,700,000$ & 1915 & $1,800,000$ & 1924 & $3,300,000$ \\
\hline 1907 & $2,700,000$ & 1916 & $4,050,000$ & & \\
\hline 1908 & $2,025,000$ & 1917 & $5,175,000$ & & \\
\hline
\end{tabular}

DEVELOPMENT

The deposit crops out about half a mile north of Jerome. Of the original outcrop not much is visible. At the present time open-cut steam-shovel workings are operated on the oxidized ore; these are gradually working downward into the hot and burning stopes of the upper levels. Two shafts extend from the surface; No. 3, starting at an altitude of 5,509 feet, reaches down vertically to the 1,950-foot level, and No. 4, starting at an altitude of 5,530 feet, only attains the 1,000 -foot level, which is the main haulage adit, termed the Hopewell tunnel.

An adit 1,200 feet long on the 500-foot level gives general access to the deposit, and from this level No. 6 shaft is sunk to the 1,950-foot level. Still another shaft, called No. 5, extends from the 800-foot to the 2,500-foot level. The ore body is opened to the 1,950-foot level, but diamond-drill holes have exposed it to the 2,700-foot level. The Hopewell tunnel is 6,600 feet long, trends north-northeast, and serves as a general outlet for the ore mined. Figure 2 illustrates the relations of these principal developments.

The levels are 150 feet apart. Drifts and other workings on the several levels aggregate many miles in length. The cross section of the rudely cylindrical ore body measures approximately 700 by 800 feet.

In stoping the square-set method, formerly used altogether, is now almost wholly replaced by several newer plans, such as horizontal cut and fill, shrinkage and fill, and incline cut and fill. Square setting with filling is still employed in places, and the surface ores, as stated, are being mined with steam shovels. The cost ranges from $\$ 3.12$ a ton for square setting to $\$ 2$ for shrinkage stoping. The total cost per ton of ore delivered at the smelter is $\$ 5.29$.

The hoisting is done by skips, and the transportation levels are provided with large ore pockets. Electric haulage is used in the tunnels, and the cars measure 18 cubic feet. The equipment in the 
way of hoisting, compressing, and pumping is unsurpassed, and most of it is electrically driven. The generating plant at Clarkdale is supplemented by power from the Arizona Power Co.

Diamond drilling is used extensively by the company at a general cost of about $\$ 5$ a foot.

The crushing plant formerly situated at the mouth of the Hopewell tunnel is now transferred to Clarkdale.

The system of ventilation is complete and modern and has been fully described by Tally in his paper on mine fires, already cited. Owing to several expensive mine fires it has been found necessary to devote much attention to this subject. As the ore is rich in sulphur it is liable to spontaneous combustion or to fires due to acci-

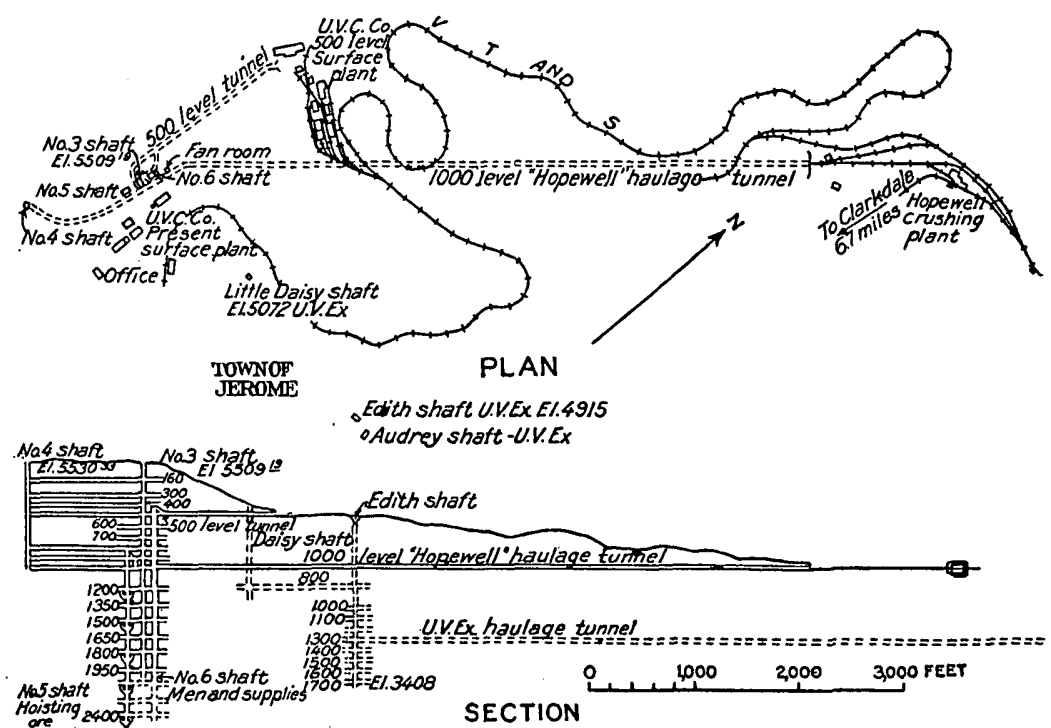

GTodre 2.-Location of shafts and tunnels, United Verde mine. After Smith and Sirdevan (Am. Inst. Min. and Met. Eng. Trans., vol. 66, p. 134, fg. 2, 1922)

dent or friction. A fire on the 400 -foot level has been burning since 1897 , and the mine is on fire in various levels from the 900 -foot upward. Mining in the fire zone has been in progress for several years under the plenum system, by which air under pressure is introduced into the workings. As far as possible the fires are isolated by bulkheads. In order to reach the burning sulphides, steam shovels were introduced in 1919 to remove $14,000,000$ cubic yards of overburden, which will permit the mining down to the 500-foot level of some $4,000,000$ tons of ore said to average 4 per cent of copper.

\section{PRECIPITATION OF COPPER}

Most of the copper-bearing mine water is derived from the natural surface drainage through the oxidized zone and the old filled stopes above the 500 -foot level, and the average flow is about 25 gallons a 
minute. This water is carried to a concrete reservoir on the 1,000 foot level through a series of diamond-drill holes. From this reservoir the water is conducted in 8-inch copper-wound redwood pipes through the Hopewell tunnel to a precipitation plant at the portal. The intake assay shows 53.1 grains of copper to the gallon, the discharge 1.2 grains, and the average recovery is 97.6 per cent. The average grade of the precipitates is 87.6 per cent.

\section{SMELTING OPERATIONS ${ }^{30}$}

The smelter at Clarkdale (pl. $12, A$ ) has a capacity of 5,000 tons of ore a day. It consists of a crushing plant and sampler; a calcining plant of twelve $211 / 2$-foot Wedge furnaces with dust chambers and a Cottrell precipitating plant; six 20 to 25 by 100 foot reverberatory furnaces; four 48 by 320 inch blast furnaces; seven stands with eight shells of Great Falls converters; and necessary pumps and compressors.

\section{MINE 'WATER}

According to Smith and Sirdevan the average flow of water in the mine is as follows: Copper-bearing water above the 1,000-foot level, 178 gallons a minute; barren water above the 1,000-foot level, 36 gallons a minute; barren water below the 1,000-foot level, 52 gallons a minute. During heavy rains the water above the 1,000 -foot level is greatly in excess of the figure given. The water below this level rarely exceeds 60 gallons. The United Verde is thus a comparatively dry mine, and little water comes in from the lower levels.

\section{GEOLOGY}

The main features of the geology of the Verde or Jerome districts have already been described. The following paragraphs refer more specially to the United Verde mine. (See figs. 3 and 4.)

In general the ore body replaces "quartz porphyry." It has a rudely circular outline and pitches steeply northwest. It has a diameter of about 800 feet and is bordered on the northwest by the concave outline of the diorite. Broadly speaking it lies between diorite and "quartz porphyry." The rocks present comprise metamorphosed sediments, "quartz porphyry," andesite dike rocks, pyritic replacement rocks, gangue including a jasper (schist replaced by silica), and black schist (chloritic replacement). The Paleozoic beds and the basaltic flows occupy parts of the surface near the mine but need not be considered here.

Metamorphosed sediments. - In the Bradshaw Mountains quadrangle the Yavapai schist is made up largely of metamorphosed sedimentary rocks, including fine-grained quartzite, chloritic, and

\footnotetext{
${ }^{80}$ Parsons, L. A., Min. and Sci. Press, Oct. 16, 1920; June 25, 1921.
} 
micaceous schist, and some limestone. In this vicinity these metamorphosed sediments are present only in small volume. Embedded in "quartz porphyry" or more commonly in greenstone schist are

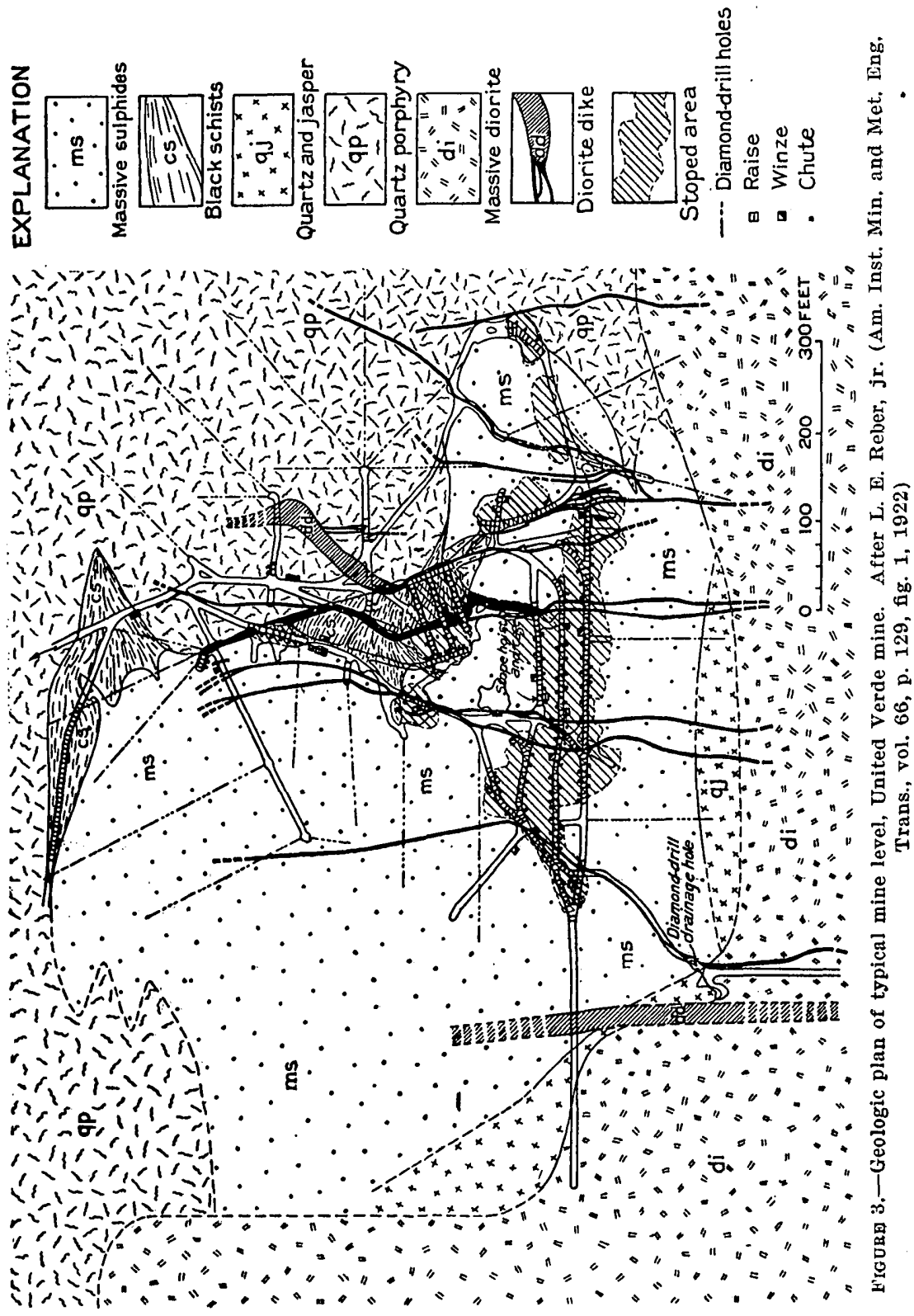

closely folded slates and cherty rocks, dipping steeply but not strongly schistose. Reber mentions the occurrence of one bed of crystalline limestone 20. feet thick. A mass of cherty rocks supposed to be altered sediments lies between diorite and ore on the west side. 
On some levels it is several hundred feet long and 10 to 20 feet thick. A section of a specimen of jasper from the 1,500-foot level is a dense dark-gray rock with conchoidal fracture containing disseminated small aggregates of pyrite and specularite. The quartz is fine grained but variable in size of grain, interlocking, with undulous extinction, and contains rude rhombohedrons or rounded masses of ankerite or siderite, replacing quartz. Grains and rude cubes of pyrite also replace quartz, and the pyrite is replaced by irregular or lamellar specularite. The microscope does not show positively whether it is an altered sedimentary rock or a schist replaced by

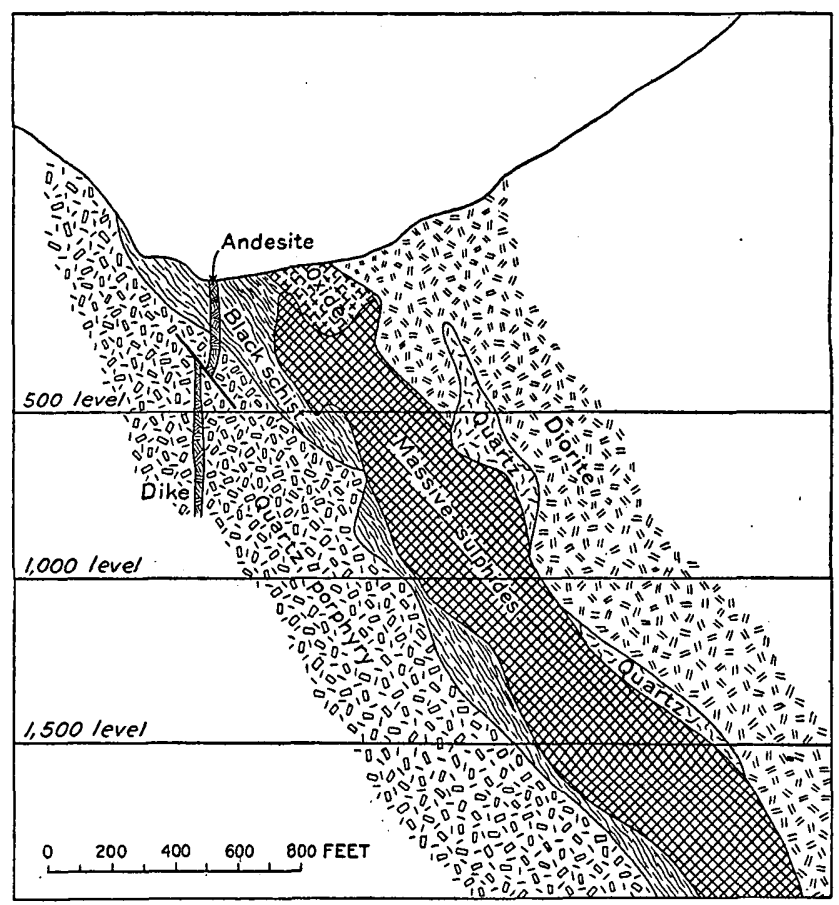

FIGURE 4.-Generalized vertical section of United Verde mine in plane of pitch. (After G. J. Young, Eng. and Min. Jour.-Press, Feb. 28, 1925)

quartz. At any rate the pyrite and specularite have been introduced during the mineralization. The contact with the diorite is sharp; in some places there is a few feet of what appears to be schistose diorite between jasper and massive diorite. The largest area of the metamorphosed sedimentary rock is indicated by Reber just north of the United Verde mine, but all of them are small.

There is little doubt that these fragments represent the oldest rocks in the district.

"Quartz porphyry."-The rocks of the greenstone complex (p. 20) are not extensively represented in the United Verde mine, but the acidic porphyries, erupted at a later date than the greenstones, are found over a large area adjoining the diorite at the south and ex- 
tensively exposed in the mine workings (fig. 3). The rock is light colored in tints of gray, yellowish, buff, and brown; it is fine grained, with phenocrysts of quartz and feldspar of varying size. "The usual composition is that of a normal rhyolite, though often an albite rhyolite and rarely a dacite." 81 In the mine the rock is in general markedly schistose, locally almost fissile, and over a large area it is also affected by silicification and pyritization. The schistosity varies considerably in degree. The strike is usually N. $20^{\circ} \mathrm{W}$.

Diorite.-The diorite, which forms a mass about three-quarters of a mile long and half a mile wide, appears mainly on the north or northwest side of the ore body. It is held by Reber to be later than the "quartz porphyry" and has been termed by him the United Verde diorite. The diorite is a dull grayish-green medium-grained rock with a somewhat porphyritic structure. Plagioclase feldspar, a little quartz, and chlorite are the principal minerals, besides sericite, calcite, and other products of decomposition. Reber refers to it as "an augite diorite with diabasic phases." The specimens I have are so much altered that neither feldspar nor ferromagnesian minerals can be determined, but the outlines of the chlorite aggregates suggest pyroxene. The diorite is generally massive and is practically nowhere mineralized, rarely containing pyrite even. Near the contacts it shows a slightly schistose structure.

Dike rocks.-All the rocks described above are cut by a series of dikes ranging in thickness from a foot or two up to 30 feet. They are not found in the overlying Paleozoic rocks; hence they must be pre-Cambrian. They are not schistose and generally cut through the ore bodies as well as the rocks. Usually they are soft and kaolinized, contain gypsum, and are known as "watercourses." Fresh material is very scarce. At best a dull-green fine-grained chloritic rock is obtained which in all probability should be classified as a diorite porphyry. The relation of these dikes to the mineralization is set forth on page 58 .

THE ORE BODY

The ore body is a rudely elliptical mass, about 800 by 700 feet in horizontal section, pitching steeply north-northwest. It is developed to a vertical depth of about 2,500 feet. The upper or northwest side of the ore body is bordered by the concave side of the diorite called United Verde diorite by Reber; the lower or south side is bordered by "quartz porphyry," some of which projects in tongues into the ore. Reber ${ }^{32}$ describes the diorite as "a steeply pitching, inverted trough of relatively impervious material, which

Reber, L. E., Jr., op. cit., p. 13.

Idem, p. 23. 
would tend to draw together and localize the deep-seated solutions in their upward course."

The greater part of the material in the ore body is "quartz porphyry," more or less replaced by pyrite and chalcopyrite. There is much massive pyrite of fine grain and low grade in copper. In this pyritic mass are richer masses containing 5 to 6 per cent of copper. They are irregularly distributed but generally elongated toward the north or N. $20^{\circ} \mathrm{W}$.; they may be several hundred feet long and as much as 200 feet wide; many of them continue through several levels; the attitude of these rudely platy masses is approximately vertical.

Each horizontal section of the deposit is similar to the next yet somewhat different.

The ore body lies about 800 feet west of the main fault and nowhere reaches it, though the fault is exposed in three places in the workings.

The total area of stoping ground developed to date on four representative levels is shown in the following table, given by Smith and Sirdevan. Nothing containing less than $2 \frac{1}{2}$ per cent of copper is considered ore. To maintain the ore reserves and to produce $80,000,000$ pounds of copper annually it will be necessary to average 100 feet of development in depth each year.

Stoping areas on four selected levels in United Verde mine

\begin{tabular}{|c|c|c|c|}
\hline $\begin{array}{l}\text { Stoping } \\
\text { area (square } \\
\text { (eet) }\end{array}$ & $\begin{array}{c}\text { A verage } \\
\text { grade (per } \\
\text { cent of } \\
\text { copper) }\end{array}$ & $\begin{array}{l}\text { Ore per } \\
\text { foot of } \\
\text { depth } \\
\text { (tons) }\end{array}$ & $\begin{array}{l}\text { Copper per } \\
\text { foot of } \\
\text { depth } \\
\text { (tons) }\end{array}$ \\
\hline $\begin{array}{l}37,520 \\
36,090 \\
48,860 \\
88,650\end{array}$ & $\begin{array}{l}5.60 \\
5.18 \\
7.99 \\
8.57\end{array}$ & $\begin{array}{r}4,461 \\
3,902 \\
6,188 \\
10,811\end{array}$ & $\begin{array}{l}249.8 \\
202.1 \\
490.4 \\
926.5\end{array}$ \\
\hline Av. 49,345 & 7.06 & 5,881 & 415.2 \\
\hline
\end{tabular}

\section{LOCAL ORE CLASSIFICATION}

The ore is essentially a schistose "quartz porphyry" replaced by silica, pyrite, and chalcopyrite. It should be again emphasized that there are in the deposit vast masses of pyrite containing 1 to 2 per cent of copper which are not utilized at present. Locally there are masses of not fully replaced schist, of cherty or jaspery gangue, and of "black schist" (see p. 66), usually high in copper. The classification of the ore is given by Smith and Sirdevan ${ }^{33}$ as follows:

For the convenience of smelter operations the ores mined are divided into four classes. Each class must be handled separately in all mining operations.

${ }^{83}$ Smith, H. D., and Sirdevan, W. H., Am. Inst. Min, and Met. Eng. Trans., vol. 66, pp. $127-181,1922$. 
Oxlde ore is mined from the oxidized zone above the 160 -foot (48-meter) level. It contains a small amount of unaltered primary sulphides but in general has a low copper content. An average assay shows the precious-metal content to be about 0.2 ounce gold and 8.0 ounces silver per ton.

Iron ore is mined from the stopes within the massive sulphide areas of the mine. If the silica content is $\mathbf{1 5}$ per cent or more it is classed as silica ore and is diverted to the silica-ore bins.

The ore from all black-schist stopes and from quartz-porphyry stopes assayIng less than 50 per cent free silica is also classed as silica ore. The analysis given in the table following shows that the term silica ore is somewhat of a misnomer, as the iron content is often in excess of the free silica contained.

An ore high in free silica is essential for use as a flux in the converters and for fettling the reverberatory furnaces. A small tonnage of: ore meeting this requirement is mined from stopes in quartz porphyry near contacts with the sedimentary schists. The main supply, however, is mined from a low-grade secondary-enrichment ore body in quartz porphyry located some distance from the main ore bodies and extending from the 160 -foot to the 600 -foot level.

Tomnage and analysis of ores, 1918

\begin{tabular}{|c|c|c|c|c|c|c|c|c|c|c|c|}
\hline Class of ore & $\begin{array}{l}\text { Dry } \\
\text { tons }\end{array}$ & $\begin{array}{l}\text { Per } \\
\text { cent of } \\
\text { total } \\
\text { ship. } \\
\text { ments }\end{array}$ & $\begin{array}{l}\text { Cop- } \\
\text { per } \\
\text { (per } \\
\text { cent) }\end{array}$ & $\begin{array}{c}\text { Gold } \\
\text { (ounces) }\end{array}$ & $\begin{array}{c}\text { Silver } \\
\text { (ounces) }\end{array}$ & $\begin{array}{l}\text { Iron } \\
\text { (per } \\
\text { cent) }\end{array}$ & $\begin{array}{l}\text { In- } \\
\text { solu- } \\
\text { ble } \\
\text { (per } \\
\text { cent) }\end{array}$ & $\left\{\begin{array}{l}\mathrm{SiO}_{2} \\
\text { (per } \\
\text { cent) }\end{array}\right.$ & $\mid \begin{array}{c}\mathrm{Al}_{2} \mathrm{O}_{3} \\
\text { (per } \\
\text { cent) }\end{array}$ & $\begin{array}{l}\text { Sul- } \\
\text { phur } \\
\text { (per } \\
\text { cent) }\end{array}$ & $\begin{array}{c}\text { Zinc } \\
\text { (per } \\
\text { cent) }\end{array}$ \\
\hline $\begin{array}{l}\text { Oxide } \\
\text { Iron } \\
\text { Silica } \\
\text { Converter_... } \\
\text { Precipitates... } \\
\end{array}$ & $\begin{array}{r}22,269 \\
422,928 \\
324,249 \\
91,479 \\
325\end{array}$ & $\begin{array}{r}2.59 \\
49.10 \\
37.65 \\
10.62 \\
.04\end{array}$ & $\begin{array}{r}1.42 \\
6.14 \\
5.05 \\
2.06 \\
67.45\end{array}$ & $\begin{array}{r}0.225 \\
.025 \\
.025 \\
.061\end{array}$ & $\begin{array}{l}8.37 \\
1.94 \\
2.06 \\
2.32\end{array}$ & $\begin{array}{r}31.5 \\
32.5 \\
25.5 \\
11.2 \\
4.3\end{array}$ & $\begin{array}{r}40.4 \\
11.5 \\
24.8 \\
71.3 \\
1.8\end{array}$ & $\begin{array}{r}34.1 \\
8.8 \\
19.3 \\
67.0 \\
1.3\end{array}$ & $\begin{array}{r}5.7 \\
3.3 \\
10.4 \\
9.9 \\
2.9\end{array}$ & $\begin{array}{r}4.2 \\
37.3 \\
21.1 \\
3.8 \\
1.0\end{array}$ & $\begin{array}{r}0.2 \\
2.6 \\
1.2 \\
.3 \\
.6\end{array}$ \\
\hline & 861,250 & 100.00 & 5. 20 & .034 & 2. 19 & 27.6 & 23.6 & 19.6 & 6.75 & 26.8 & 1.77 \\
\hline
\end{tabular}

The mineral composition of the several classes of ore as calculated by Reber is given in the following table:

Mineral composition of ores from United Verde mine

\begin{tabular}{|c|c|c|c|c|}
\hline & Oride & Iron & Silica & $\begin{array}{c}\text { Con- } \\
\text { verter }\end{array}$ \\
\hline $\begin{array}{l}\text { Pyrite } \\
\text { Chalcopyrite } \\
\text { Sphalerite. } \\
\text { Chalcocite } \\
\text { Cuprite, native copper, and carbonates. } \\
\text { Cuprite } \\
\text { Sulphases and carbonstes of iron, copper, and lime } \\
\text { Iron oxides. } \\
\text { Ferruginous chlorite } \\
\text { Quartz } \\
\text { Silicates (sericite, hornblende, kaolin, etc.) } \\
\text { Calcite and siderite }\end{array}$ & 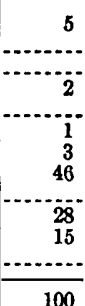 & $\begin{array}{r}2 \\
5 \\
10 \\
2\end{array}$ & 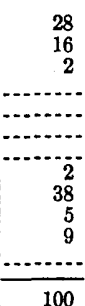 & $\begin{array}{r}5.75 \\
1.00 \\
.50 \\
1.50 \\
.25 \\
11.00 \\
6.00 \\
54.00 \\
20.00 \\
\end{array}$ \\
\hline
\end{tabular}

THE ORES IN DETAIL

General character.-The ores of the United Verde mine are very similar in character throughout. They are fine-grained aggregates of pyrite with quartz, dolomite, and chlorite as gangue and minor 
quantities of sphalerite, chalcopyrite, arsenopyrite, and tennantite. (See pls. $7, A, B ; 8, A, B ; 9, A ; 10, B ; 11, A, B$.) They are throughout the products of replacement, mainly of schistose rhyolite porphyry, less commonly of sedimentary rocks such as chert and slates.

A banded structure is visible in much of the ore, owing to the parallel arrangement of pyrite, gangue, chalcopyrite, or sphalerite, but this banding is nowhere very conspicuous. It is caused mainly by the influence of schistosity on replacement, but may also be caused by fracturing which took place mostly after the deposition of the pyrite. There is one major direction of fracturing, which appears to be parallel to the schistosity, and two others at about $45^{\circ}$ to the major direction. Most of the ore is to all appearance a massive sulphide, but search along the outlines of the ore bodies discloses all stages of transition. Many of the ores still contain the quartz phenocrysts of the original rhyolite porphyry.

Paragenesis of minerals.-Quartz occurs in small grains, the largest being the residual phenocrysts. Most of the quartz forms interlocking aggregates; minute grains show undulous extinction and fibrous (chalcedonic?) texture. Some of the quartz is residual from original rock (rhyolite porphyry, quartzite, chert, slate); some, however, is later than pyrite and may surround it as coarsely fibrous aggregates. The deposition of quartz continued with decreasing intensity after that of sphalerite and to some extent even after that of chalcopyrite and tennantite. Dolomite or ankerite replaces quartz in irregular aggregates or more or less well-defined rhombs. Siderite was not observed, but calcite is present here and there and is in part of very late origin.

Sericite in the usual foils, shreds, or aggregates is commonly present and is abundant in some schist ores. The mineral replaces feldspar and quartz and is one of the earliest of the secondary constituents. Residual feldspar is very rare.

Chlorite appears with sericite, particularly in the ores clearly derived from rhyolite porphyry schist. In such ores it is intergrown with sericite, replaces older silicate minerals and quartz, and has the usual optical characteristics, appearing nearly dark between crossed nicols.

Ferriferous chlorite in dark-green, almost black aggregates and minute foils is a very characteristic gangue mineral of some types of schist ores. Usually it is accompanied by much chalcopyrite. This chlorite was undoubtedly formed by the ascending solutions and appears under the microscope as light-green confused fibrous aggregates, having light-gray colors of the first order between crossed nicols. 


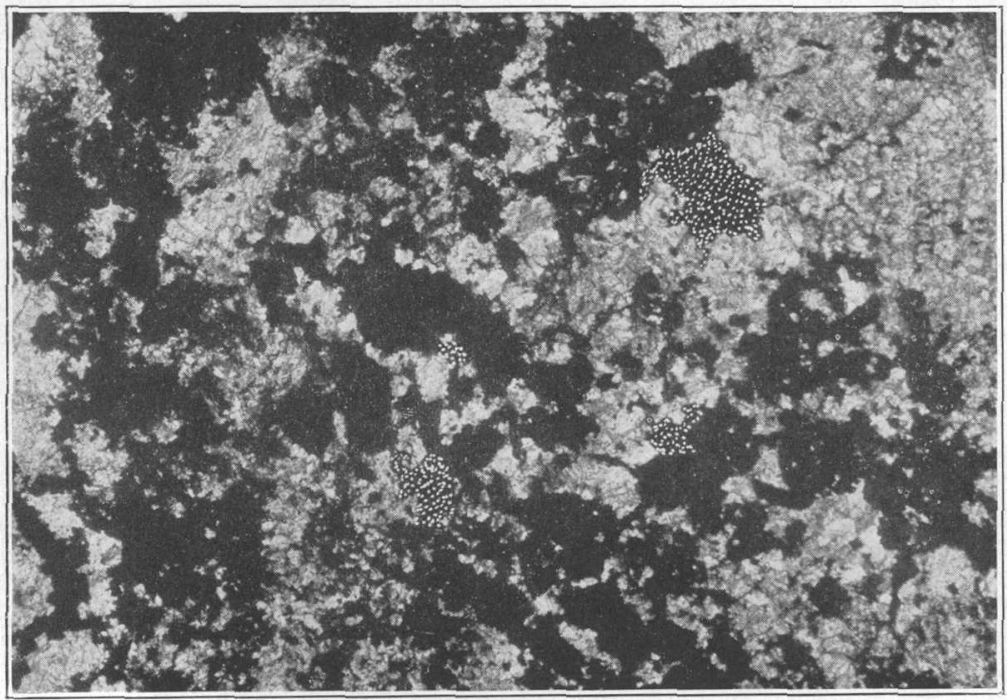

A. ORE FROM 500-FOOT LEVEI

Pyrite (black) and sphalerite (stippled) in matrix of dolomite

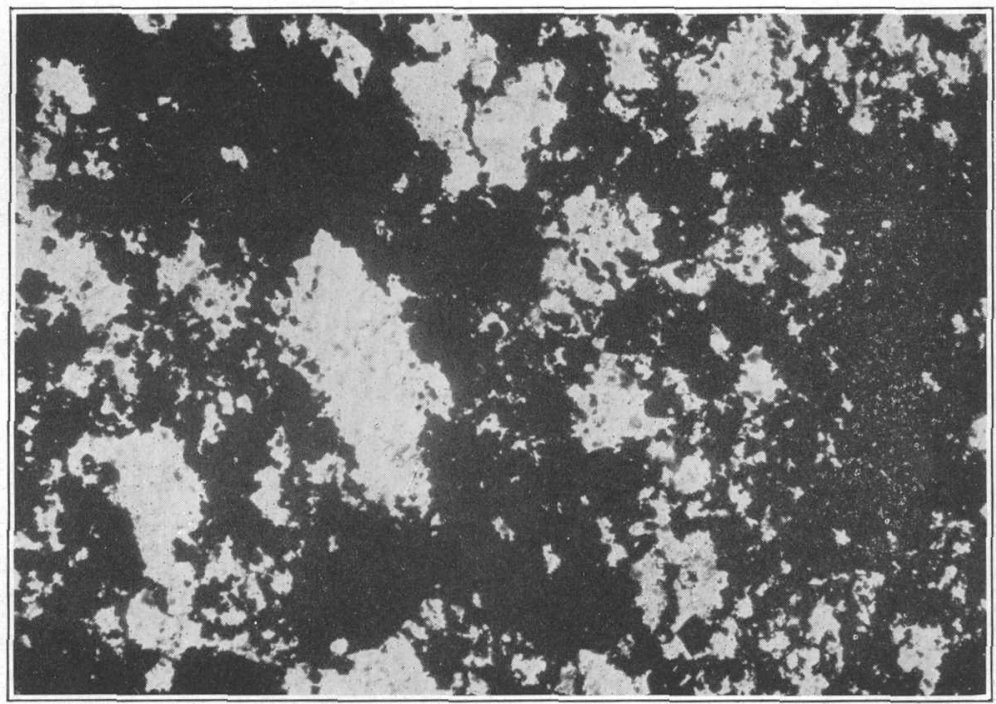

B. ORE FROM 1,000-FOOT LEVEL

Pyrite, sphalerite, and chalcopyrite (black), partly alined, in quartz mosaic with a little dolomite

Photomicrographs OF THIN SECTIONS SHOWING PYRITIC ORE FROM UNITED VERDE MINE

Enlarged 32 diameters. Ordinary light 


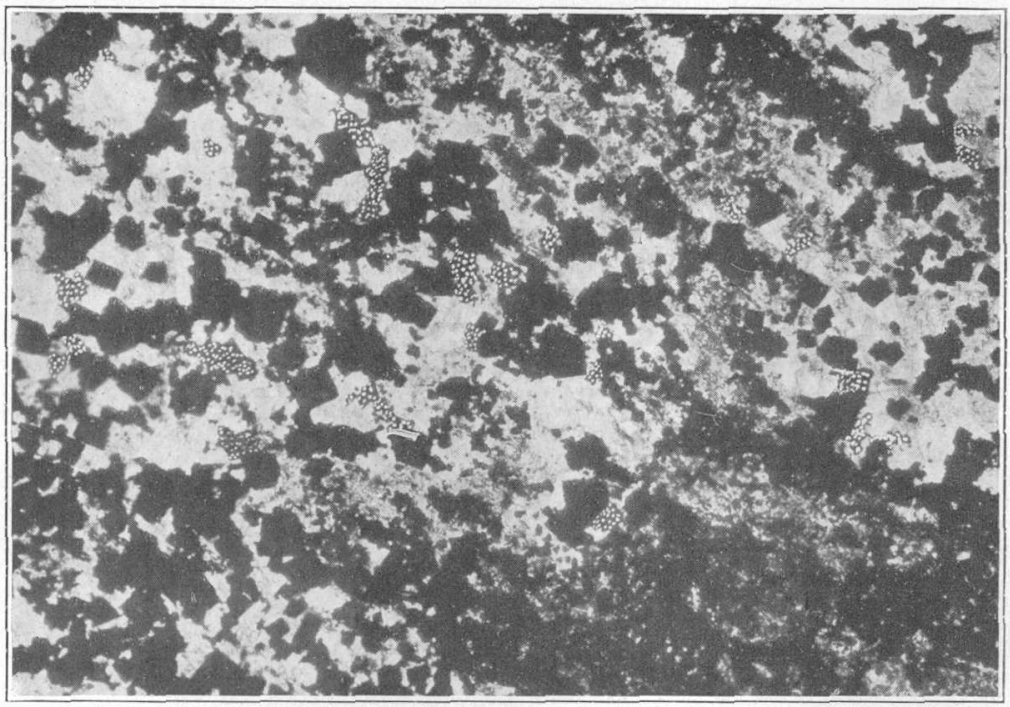

A. ORE FROM 1,650-FOOT LEVEL

Pyrite, chalcopyrite (black), and sphalerite (stippled) in quartz mosaic with some sericite. Sulphides replacing sedimentary schist

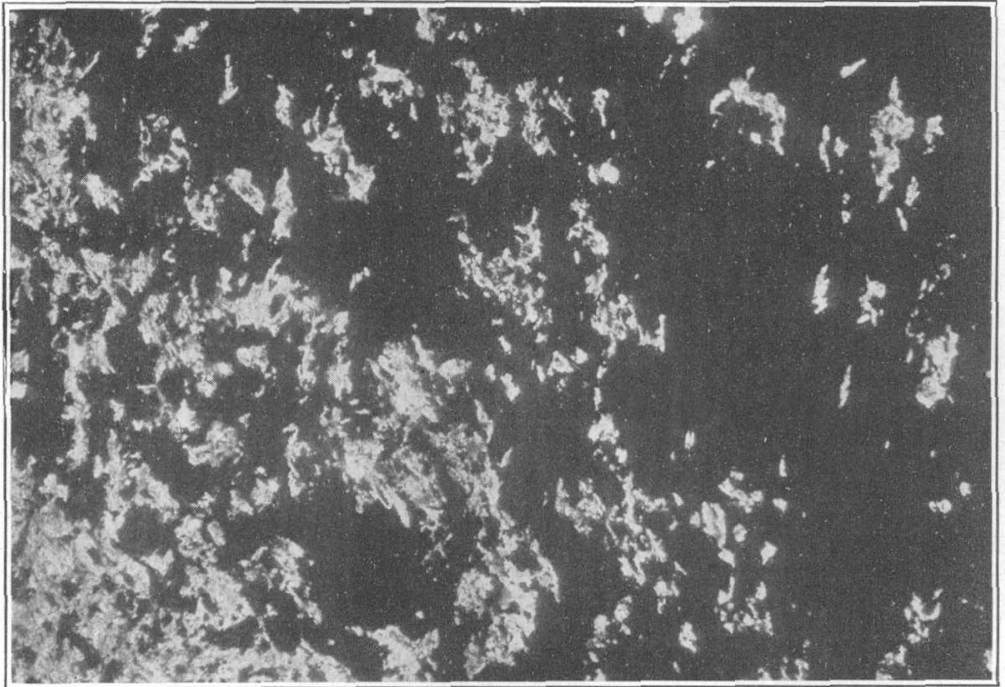

B. ORE FROM 650-FOOT LEVEL

Much chalcopyrite with some pyrite and sphalerite (black)., Sulphides replacing ironrich chlorite (light gray) ("schist ore")

PHotomicRograpHS OF THIN SECTIONS SHOWING PYRITIC ORE FROM UNITED VERDE MINE

Enlarged 32 diameters. Ordinary light 


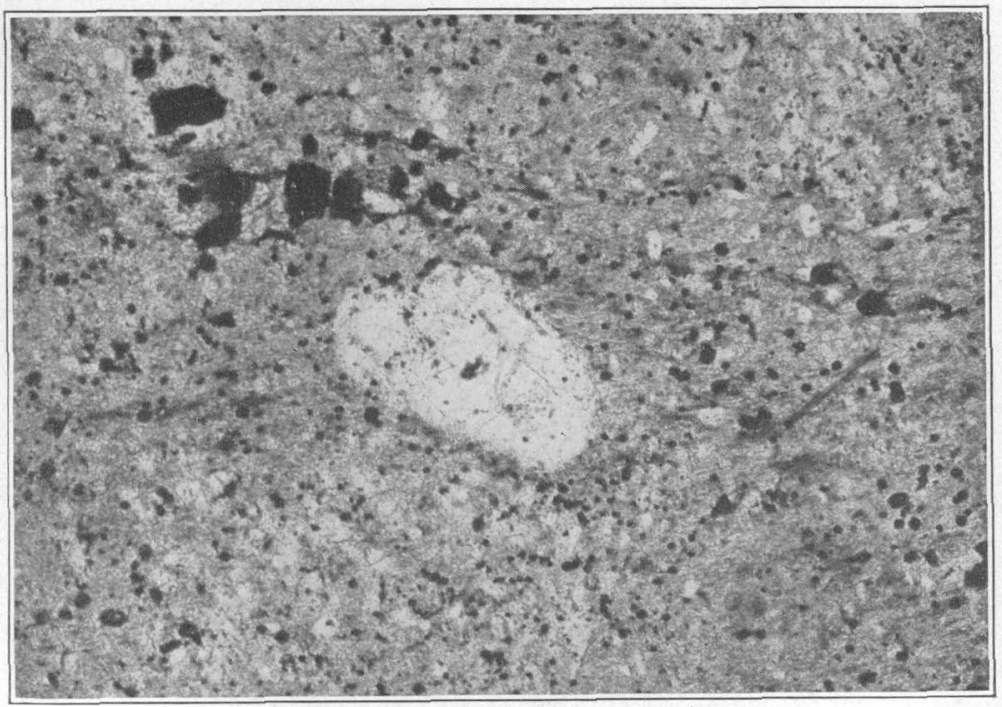

A. PYRITIC ORE FROM 1,500-FOOT LEVEL, UNITED VERDE MINE

Pyrite, magnetite, and chalcopyrite (black) in schist mosaic of quartz, sericite, and dolomite (light gray). Schist derived from rhyolite porphyry, a phenocryst of which appears in the photograph

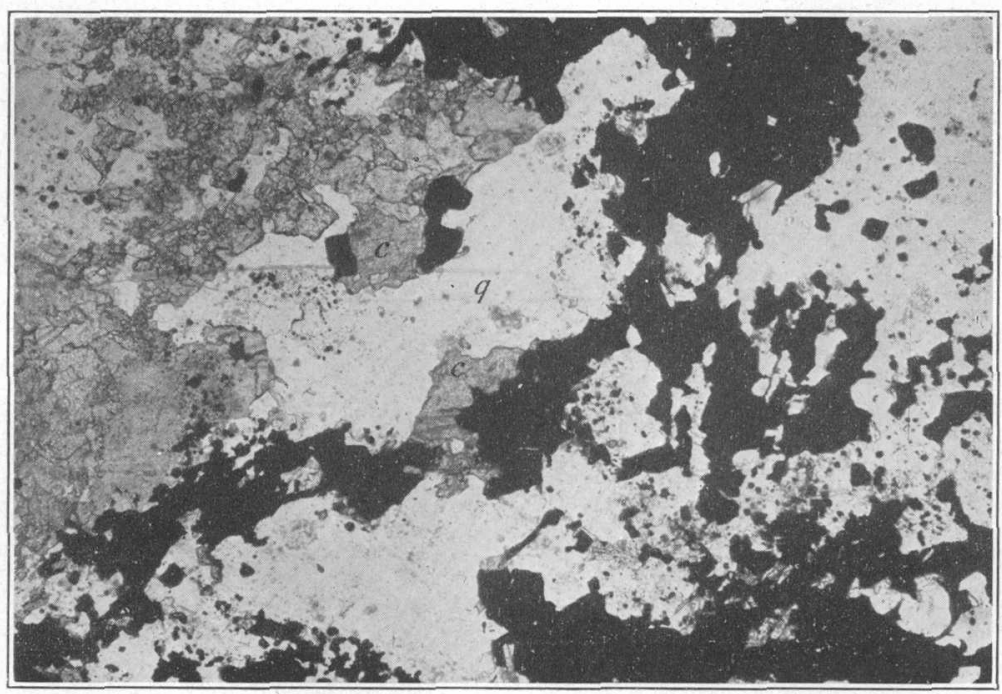

B. ORE FROM 1,000-FOOT LEVEL, BLUE BELL MINE

Pyrite and chalcopyrite (black) in mosaic of quartz $(q)$ and calcite $(c)$. Replacement of schist

PHOTOMICROGRAPHS OF THIN SECTIONS SHOWING ORES

Enlarged 32 diameters. Ordinary light 


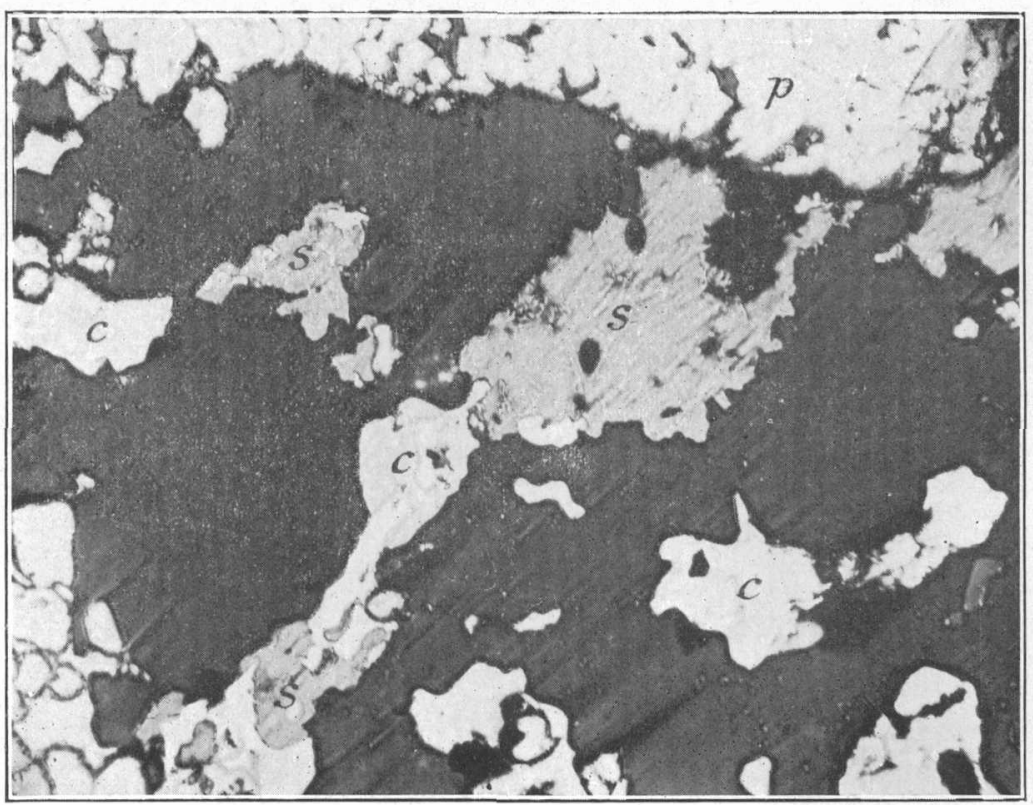

A. ORE FROM COPPER CHIEF TUNNEL

Veinlet of quartz (black) with chalcopyrite $(c)$ and sphalerite $(s)$ cutting massive pyrite $(p)$

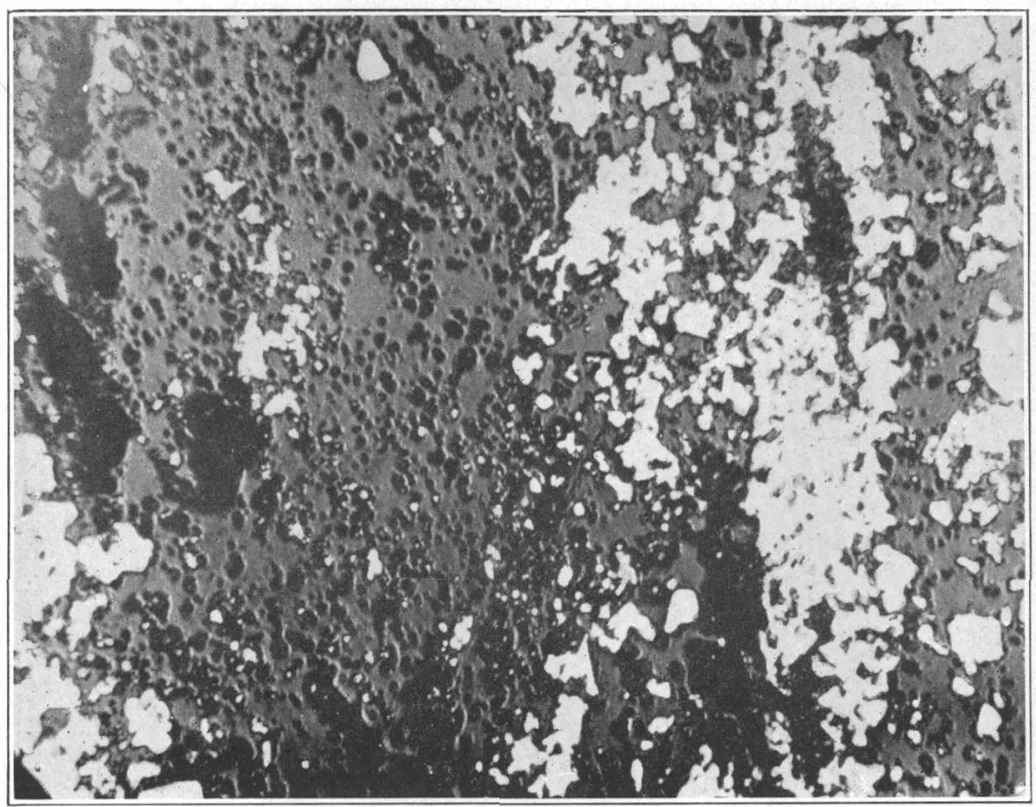

B. ORE FROM STOPES ABOVE 300-FOOT LEVEL, UNITED VERDE MINE

Pyrite (white) replacing jaspery schist (dark gray) along planes of schistosity

Photomicrographs OF POLISHED SECTIONS SHOWING ORES 

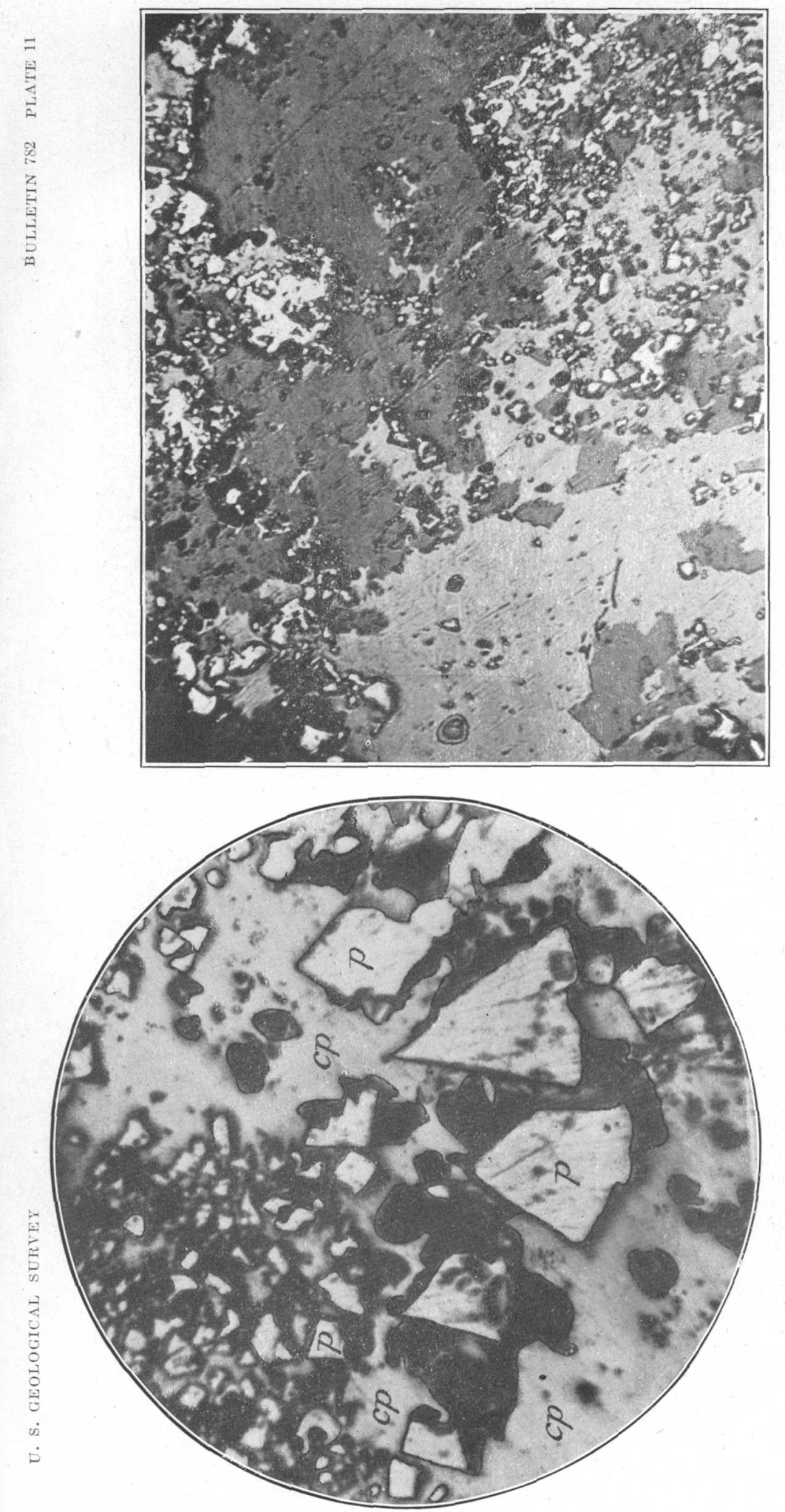

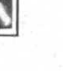




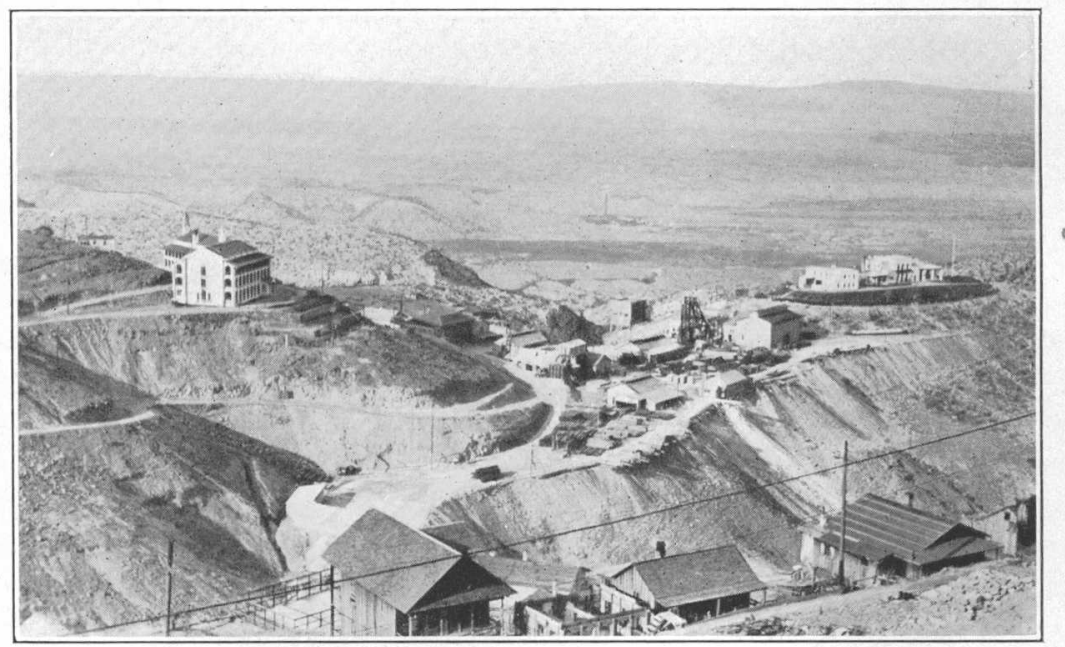

A. VIEW LOOKING EAST FROM JEROME ACROSS VERDE VALLEY

Showing Edith shaft of United Verde Extension mine. Clarkdale smelter in bottom of valley

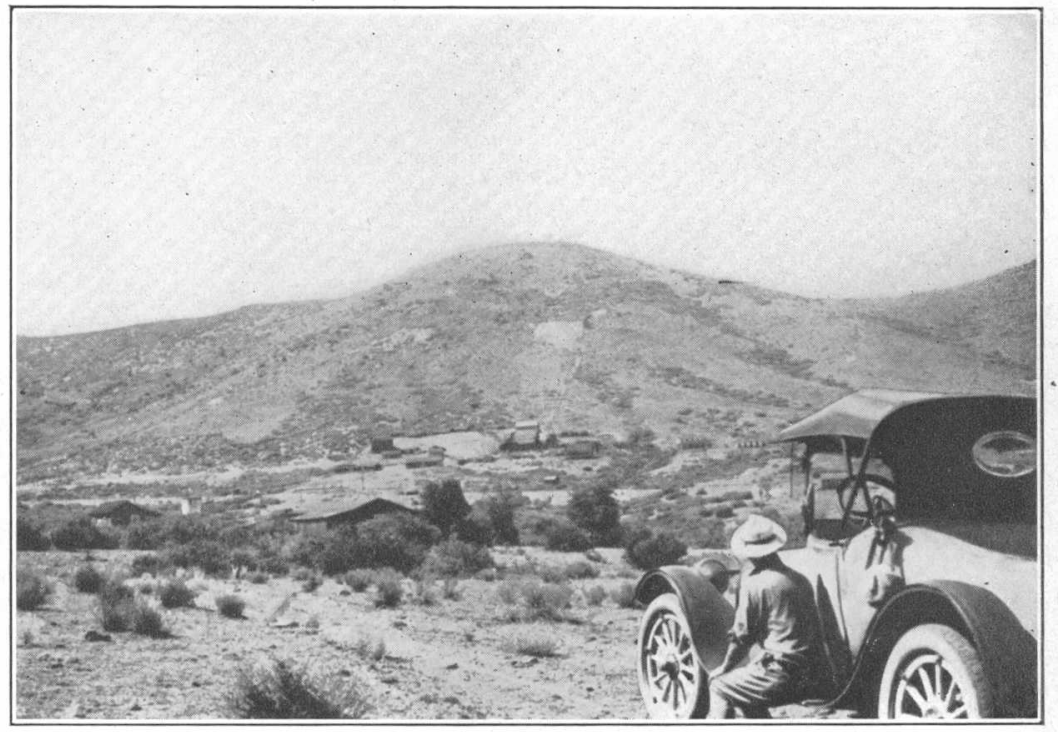

B. VIEW LOOKING NORTH FROM BIGBUG CREEK

Henrietta mine in background 
Rutile in milky, opaque aggregates and well-developed small crystals is common in all schist ores that do not contain too much pyrite; it is derived from the original titaniferous minerals of the rock.

Pyrite occurs normally in minute cubes or aggregates of small grains and is in part alined in rude bands or streaks. The pyrite replaces quartz, though it was also followed by later quartz and is the oldest of the sulphides. After the deposition of the pyrite many of the aggregates were shattered and minutely fractured.

Magnetite and specularite occupy a peculiar position in this ore body. They are not normal constituents of the ore but appear here and there, in the jaspery masses between diorite and ore or in the schist ore. Both are distinctly later than the pyrite but earlier than the other sulphides. Where they occur together the specularite is invariably the later and incloses residual fragments of magnetite.

Arsenopyrite in small crystals is embedded in quartz and is found in almost every specimen in scant amount. It seems to be a little later than the pyrite.

Sphalerite is relatively abundant. It occurs both in the lowgrade pyrite masses and in the ore, locally in so great amounts as to suggest the possibility of utilization. It is pale yellow or grayish white and has a darker rim. The polished sections give no clue to the nature of this dark pigment. It is probably not caused by iron. The purity of the sphalerite in an ore so rich in pyrite is puzzling. The mineral is distinctly later than the pyrite, which it replaces and surrounds. It is often alined in parallel streaks with later quartz and ankerite. Small grains of galena in places accompany sphalerite but are of later origin.

Chalcopyrite is later than sphalerite, though it evidently belongs in the same phase of mineralization. It replaces all the earlier minerals and is particularly common in shattered pyrite aggregates.. It forms linear streaks in some of the ore.

Tennantite is distinctly the latest ore mineral, though not much later than the chalcopyrite. It replaces any of the older minerals and is usually accompanied by dolomitic coarse-grained gangue, in places forming veinlets in the ores. In polished section where inclosed in chalcopyrite it takes on a bluish tinge.

The secondary minerals include calcite, abundant gypsum, chalcocite, cuprite, and residual quartz. They are referred to in more detail in the paragraph on the oxidized ores.

Types of pyritic ores.-The most common dense pyritic ore is an aggregate of pyrite in small cubes and grains between which lies a fine aggregate of quartz of various ages. Rude banding by streaks of pyrite, chalcopyrite, and sphalerite is not uncommon, and in 
some of the ore there are finer and thinner streaks of sphalerite. The chalcopyrite is not conspicuous. The quartż everywhere contains more or less ankerite. A less common type of ore shows only pyrite with smaller amounts of other sulphides embedded in a scant matrix of dolomite or ankerite.

Less abundant are also the ores that replace a fine-grained quartzite and those that replace schists and jaspers of undoubted sedimentary origin. These ores in places show banding by pyrite, which occurs in a fine-grained quartz-sericite matrix with small rhombs of dolomite or ankerite.

Most of the ores so far described appear very fine grained in specimens, irrespective of the proportion of chalcopyrite present, and form what is known at the mine as "iron ore." Their average composition is given on page 71 .

The so-called "converter ore" is simply a partly replaced highly siliceous rhyolite porphyry with as much as 2 per cent of copper. In part it is mined on the upper levels (down to the 600-foot level) and contains in addition to pyrite and chalcopyrite some secondary chalcocite.

The so-called "silica ore" or "schist ore" deserves some special comment. The term "silica ore" is a misnomer and is used merely to indicate that the material contains more silica than the normal "iron ore." The average silica content is in fact only 19 per cent. These ores have been produced by the replacement of schist in which there has been formed an unusually large amount of the ferriferous chlorite described above. They occur locally in points of schist projecting into the usual pyritic ores and contain proportionately more chalcopyrite, some of it in considerable masses of the pure mineral. These ores are rather more coarsely crystalline than the ordinary ore, as the pyrite and sphalerite occur in larger individuals. Their average copper content is 5.05 per cent. In many places they appear as black schistose masses with veins and aggregates of coarse chalcopyrite. According to the above table they are estimated to contain about 38 per cent of chlorite, which is to be considered as a gangue mineral and is somewhat earlier than the chalcopyrite. In places are found pseudoamygdaloid rocks made up of fine felted chlorite and rounded replacing aggregates of dolomite. Rutile is common in these ores.

It is entirely possible that in part these schist ores are derived from sedimentary slates, and it is not always easy to distinguish their origin. One illuminating specimen shows a fine-grained darkgray chloritic rock containing small disseminated pyrite cubes; the specimen is cut by a vein of chalcopyrite 8 millimeters thick with a little quartz, lined on both sides with radially arranged chlorite foils about 1 millimeter wide. The chlorite is light green and has a 
small optical angle. This occurrence closely connects the chlorite with the slightly later chalcopyrite and indicates a rather distinct phase of copper-bearing solutions.

Oxidized ores.-Of the actual outcrop of the United Verde ore body there is little to be seen at the present time. Reference has been made above to the mine fires, which have been raging above the 500-foot level in the upper sulphide stopes, and to the mining of such stopes by the plenum method. A few years ago it was decided to mine the whole upper part down to the 400 -foot level by the open-cut method, using steam shovels. This plan is well under way now, and of course both the outcrops and much of the surrounding rock have been removed. Figure 5 shows the extent of this plan. In 1922 the shovels had already begun to reach the hot areas, and sulphur fumes were ascending in the cracks and fissures.

For the character of the outcrop we are largely dependent upon the descriptions of Reber and earlier authors. It will be remembered that the outcrops were located at an altitude of about 5,520 feet and that the nearest outcrops of the former cover of basal Paleozoic sandstone are 500 feet above this. The destruction of the oxidized zone had therefore progressed far when mining operations began.

The oxidized ores are considered to reach to the 160 -foot level, where the sulphides begin without any well-marked chalcocite zone. The composition of the oxide ore given on page 71 shows 28 per cent of quartz, 46 per cent of iron oxides (limonite and specularite), 2 per cent of chalcocite, 1 per cent of cuprite, malachite, etc., and 15 per cent of silicate. The ore averages only 1.42 per cent of copper. It is considerably higher in gold and silver than the pyritic ores, containing about ten times as much gold and four times as much silver. The figures given for the oxide ore are 0.225 ounce of gold and 8.37 ounces of silver to the ton; for the sulphide ore 0.025 ounce of gold and 1.94 ounces of silver. The minerals contained are quartz, limonite, specularite, native copper, cuprite, malachite, azurite, covellite, chalcocite, residual pyrite, silver, sericite, kaolin, and various sulphates of copper, iron, and lime.

There are large masses of fine-grained jaspery material, mostly gangue of leached ore; these contain limonite and secondary specularite and are usually very hard. Malachite is not abundant.

Reber ${ }^{34}$ states that "sometimes a thin layer of high-grade silver ore, in which native silver is conspicuous, immediately overlies the sulphides."

From the level where the massive sulphides begin down to the 600 -foot level there is some chalcocite in the ore, probably in part of

${ }^{34}$ Op. cit., p. 17. 
pre-Cambrian, in part of post-Tertiary age. The amount decreases gradually. In the so-called converter ore, which is a partly replaced and somewhat chalcocitized rhyolite porphyry occurring outside of the main body, we find chalcocite down to the 600-foot level. This ore averages 2.06 per cent of copper and 0.061 ounce of gold and 2.32 ounces of silver to the ton; both gold and silver are somewhat higher than the normal for pyritic ore. Besides chalcocite the converter ore contains a little pyrite, chalcopyrite, and sphalerite.

At the present time oxidizing conditions extend along the dikes or "watercourses" to the bottom of the mine and cause the formation of much gypsum, kaolin, and probably some calcite. In the main sulphide bodies the oxidation is not noticeable below the 600 -foot level.

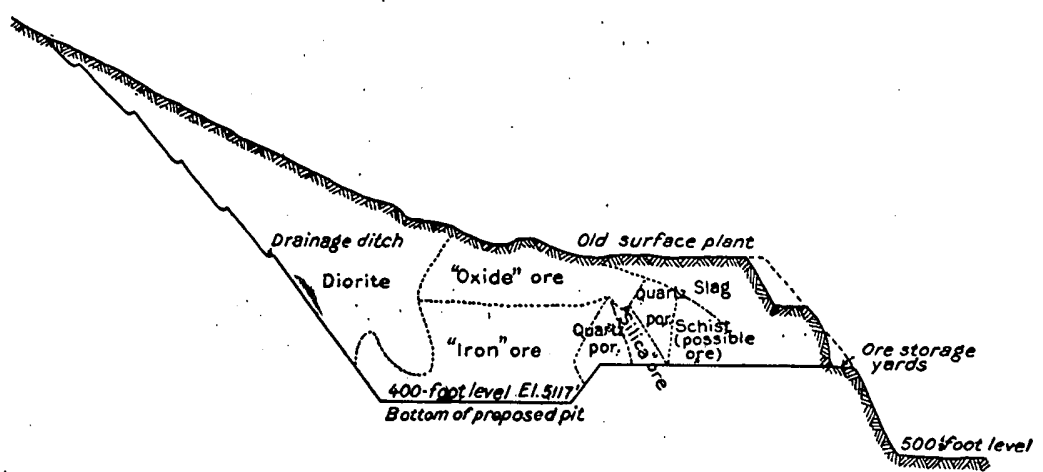

Figure 5.- Section showing outcrop of United Verde mine and proposed operations of steam shovel. After Lewis A. Parsons (Min. and Sci. Press, April 2, 1921)

ORIGIN OF THE DEPOSIT

The genesis of this great deposit is not easy to discuss in a few lines, and, indeed, there are many problems in connection with it which are still unsolved.

The ore body forms a rudely cylindrical mass pitching steeply north-northeast and maintaining its size as far as it has been followed to a depth of 2,500 feet. The diameter is about 700 feet. It lies in pre-Cambrian rocks on the west or upthrown side of the great Verde fault. The Paleozoic sediments rest horizontally on the pre-Cambrian about 500 feet above the outcrops of the ore body. The upper part of the body, having been exposed since the fault movement to erosion and oxidation, has been leached and oxidized down to a depth of several hundred feet below the outcrop. Below this are massive sulphides.

The ore body has for its sharply defined.upper, concave wall the inverted trough of the diorite called United Verde diorite by Reber. 
This rock' is massive and hard and is practically unaffected by any mineralization. At the lower boundary, also concave, lies schistose rhyolite porphyry, in places projecting in points into the sulphide mass.

The ore body mainly replaces rhyolite porphyry ("quartz porphyry ") and outside of the ore body this rock is in places more or less mineralized. All these rocks and the ore itself are cut by east-west narrow dikes of "andesite porphyry," which in places contain disseminated pyrite and veinlets of sphalerite, chalcopyrite, tetrahedrite, dolomite, and quartz.

The main ore body has a scant gangue of fine-grained quartz with more or less of ferruginous chlorite, dolomite, ankerite, and calcite. The main ore body contains, in the order of introduction, arsenopyrite, pyrite, magnetite, specularite, sphalerite, chalcopyrite, and a little tennantite. The later sulphides fill and replace fractured pyrite and quartz. The association of richer masses of chalcopyrite with chlorite ("schist ore," in part) is locally characteristic. Each later sulphide or oxide replaces earlier sulphides or oxides.

On the basis of these facts we obtain the following succession of events from older to younger:

1. Deposition of bedded pre-Cambrian sediments.

2. Flows of "greenstones."

3. Intrusion of rhyolite porphyry ("quartz porphyry").

4. Dynamic metamorphism expressed in schistosity.

5. Intrusion of diorite.

6. Continued static metamorphism of preceding rocks.

7. Pyritic mineralization, evidently by ascending solutions in crushed zone of rhyolite porphyry adjoining diorite.

8. Intrusion of dikes of " andesite porphyry."

9. Extensive fracturing of pyritic mass.

10. Continued mineralization by magnetite, specularite, sphalerite, chalcopyrite, and tennantite, chiefly affecting already present pyritic masses.

11. Long pre-Cambrian to Devonian (?) period of peneplanation, oxidation, and development of chalcocite zone. Chalcocite penetrating at most to depth of 800 feet below surface, under conditions of arid climate and deep water level.

12. Sealing of deposit by deep Paleozoic sedimentation.

13. Late (postbasalt) dislocation of 1,700 feet or more, followed by erosion. Deposit and particularly its gossan and chalcocite zone laid bare.

14. Rapid oxidation resulting in the destruction of the enormous chalcocite zone, leaving residual ferruginous jasper, limonite, cuprite, etc., with some residual chalcocite. Oxidation penetrating along dikes to great depth but leaving most of sulphide mass unaffectod.

Several questions suggest themselves in considering this chronology. There can scarcely be any doubt that the intrusion of diorite preceded the mineralization, and yet it is difficult to explain the absence of mineralization from the diorite. The evident explana- 
tion would be that the rock was so hard and massive that the solutions could not penetrate the smooth wall which it presented to the adjoining rhyolite porphyry schist.

Another question relates to the dikes. It is evident that they were intruded during the later phases of mineralization, but like the diorite they were not readily penetrated by the solutions. The peculiar position of the scant magnetite and specularite in the table of succession of minerals is noteworthy. Usually they are older than pyrite. Benedict ${ }^{35}$ has suggested, probably correctly, that these minerals were formed during a temporary increase of temperature caused by the intrusion of the dikes. The formation of this specularite should not be confused with the development of the same mineral in the gossan during weathering under conditions of a torrid climate.

It is concluded that the deposit was formed at a considerable depth below the surface existing at the time of genesis and under conditions of high temperature and pressure. The absence of minerals of distinctly high-temperature origin is noteworthy, as is also, on the other hand, the absence of barite, which is so common in massive pyrite deposits like those of Rio Tinto, Rammelsberg, and Shasta County. The ores of United Verde, with their fine-grained banded texture, are otherwise very similar to those of the localities just mentioned.

Beyond doubt the United Verde ore body was formed by ascending solutions of deep-seated origin. At least, as Reber remarks, the burden of proof is on those who would assert otherwise. In attempting to answer the question from what particular source, or place of concentration, these solutions were derived it is well to go slowly. The most probable conclusion is that these solutions separated from a magma in a deep-seated reservoir. They were certainly not derived from the rhyolite porphyry, nor from the diorite, nor from the dikes now adjoining the ore body.

We know that this whole pre-Cambrian complex is underlain by a vast batholith of Bradshaw granite, and to this batholithic magma, or to one derived from it, we must look for the origin of the hot ascending solutions.

The deposit is explored to a depth of 2,500 feet below the outcrop, or 3,000 feet below the pre-Cambrian peneplain. It is known below this depth by diamond drilling. Probably not less than 2,000 feet of this long inclined rod-shaped chimney has been removed by preCambrian erosion. It follows that its total length must have exceeded 5,000 feet. The probability is strong that it extends far below the present deepest soundings, at least if the present structural conditions persist in depth.

\footnotetext{
${ }^{35}$ Benedict, P. C., Geology of Deception Gulch and Verde Central mine (thesis, Massachusetts Inst. Technology, 1923).
} 


\section{UNITED VERDE EXTENSION MINING $\mathrm{CO}^{36}$}

\section{LOCATION AND HISTORY}

The property of the United Verde Extension Mining Co., of which James S. Douglas is president and George Kingdon general manager, mainly adjoins on the east that of the United Verde Copper Co., though in part the claims belonging to the Hull Copper Co. and that of the Jerome Verde Development Co. intervene. The company owns 1,200 acres, of which four claims, known as the Little Daisy group, include the main ore body and the development work; besides this the company owns several outside properties and, it is understood, has an option on the lands of the Jerome Verde Development Co. The Little Daisy group is situated at an altitudo a few hundred feet lower than the property of the United Verde Copper Co. The Edith and Audrey shafts are 4,908 feet above sea level (fig. 6). The company is usually known in the district as the "U. V. X."

The first location of the Little Daisy Fraction was made by J. J. Fisher in 1900, according to T. A. Rickard. In 1902 the United Verde Extension Co. was organized, and it acquired besides the Little Daisy four full adjoining claims, formerly belonging to the Hull Copper Co. The Little Daisy shaft was sunk 300 feet through lava and limestone and 500 feet deeper into the pre-Cambrian, where some promising material was found but no ore bodies. It should be recognized that the U. V. X. mine is just east of the Jerome fault, where the older rocks are deeply buried under "malpais" (basalt) and Paleozoic limestone. Undoubtedly the organizers of the company were looking for the upper, down-faulted part of the United Verde ore body. Partly leached ore was found in 1911 in a winze below the 800 -foot level, and much leached ore on the drifts on the same level. The exploratory drifts on the 800 -foot level had now reached 1,000 feet or more east of the shaft. Another patch of chalcocite ore was encountered on the 700 -foot level.

In 1912 James S. Douglas, son of the late Dr. James Douglas, of Phelps, Dodge \& Co., became favorably impressed with the property and obtained an option. Several reports had been made, many of them unfavorable. It is easy now to condemn these mining engineers who reported adversely, but the enormous amount of money spent in the district in the vain attempt to find ore outside of the United Verde was a discouraging consideration, and the known facts probably did not clearly point to underlying ore bodies. With some difficulty money was provided- $\$ 225,000$, it is said-to carry

${ }^{86}$ Weed, W. H., Mines Handbook, vol. 15, pp. 423-426, 1922. Rickard, T. A., The Story of the United Verde Extension bonanza: Min. and Sci. Press, vol. 116, pp. 9-16, 47-52, 1918 (an excellent description of the mine). Finlay, J. R., The Jerome district of Arizona : Eng. and Min. Jour., vol. 106, Sept. 28 and Oct. 5, 1918. 
out further exploration, and a new shaft was sunk 1,740 feet east of the Little Daisy shaft.

The Edith shaft (altitude of collar 4,908 feet) was sunk through 180 feet of lava, 400 feet of limestone, and 90 feet of Tapeats sandstone, and reached the pre-Cambrian at 678 feet, which was equivalent to the 800-foot level of the Daisy shaft. (See pl. 12, A.) Resultless explorations were extended into the claims of the Jerome

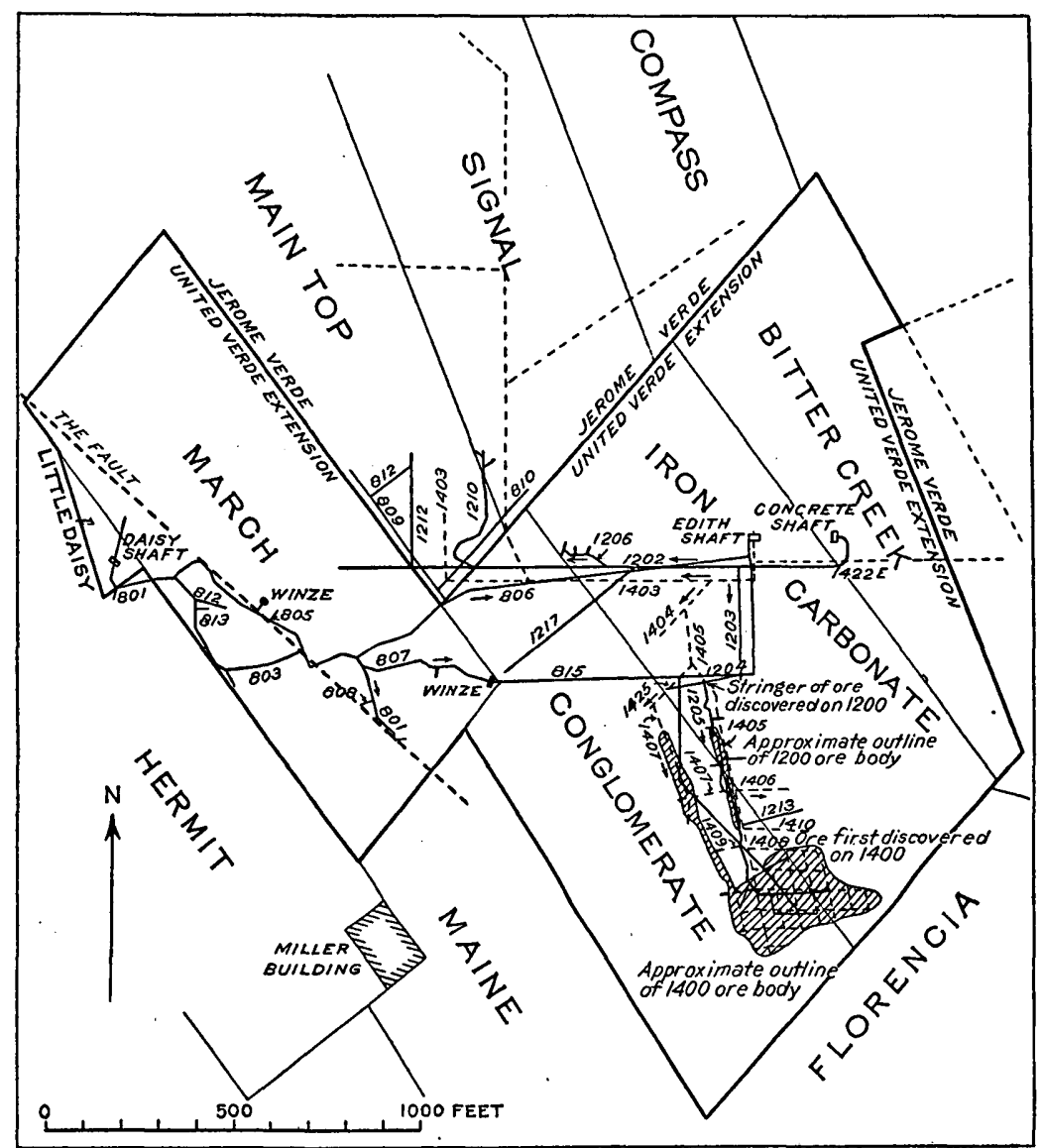

Figuab 6.-Plan of Initial workings of the mine of the United Verde Extension Co. After T. A. Rickard (Min. and Sci. Press, vol. 116, p. 15, 1918)

Verde Co. on the 800 and 1,200 foot levels. The search for ore in U. V. X. ground likewise proved disappointing. The Edith shaft was deepened to 1,400 feet. No ore was found in the Jerome Verde ground, and assessments were called for, all to no avail. At this time, Rickard states, the services of an eminent geologist were obtained. This gentleman, "whose name is purposely withheld," condemned the mine and advised his clients to withdraw. I am not sure but that sympathy should be extended to this geologist. One 
level. Pumps were installed on the 1,400-foot level. At the present time the water drains through the main adit on the 1,300-foot level, and little water is encountered on the deeper levels.

\section{PRODUCTION AND DIVIDENDS}

The following table gives the production of the mine since 1916 . The figures are given in the annual reports of the company and in the articles on the mine production of Arizona in the volumes of Mineral Resources published by the United States Geological Survey.

Copper, gold, and silver produced by United Verde Extension Mining Co., 1915-19\$4

[Compiled by V. C. Heikes, U. S. Geological Survey]

\begin{tabular}{|c|c|c|c|c|}
\hline Year & Crude ore & Copper & Gold & Silver \\
\hline $\begin{array}{l}1915 \\
1916 \\
1917 \\
1918 \\
1920\end{array}$ & $\begin{array}{r}\text { Tons } \\
9,275 \\
77,461 \\
115,064 \\
133,535 \\
93,325 \\
161,617 \\
57,073 \\
136,738 \\
172,629 \\
188,038\end{array}$ & $\begin{array}{r}\text { Pounds } \\
5,138,989 \\
36,402,972 \\
63,879,506 \\
55,491,077 \\
28,860,615 \\
41,942,700 \\
12,782,316 \\
30,600,200 \\
41,855,959 \\
42,417,869\end{array}$ & $\begin{array}{r}\text { Fine ounces } \\
183.00 \\
2,570.52 \\
2,646.47 \\
3,046.00 \\
3,169.00 \\
5,530.00 \\
1,121.00 \\
4,863.00 \\
8,992.00 \\
8,532.90\end{array}$ & $\begin{array}{r}\text { Fine ounces } \\
19,393 \\
128,467 \\
346,342 \\
503,739 \\
272,855 \\
359,370 \\
106,350 \\
198,080 \\
257,602 \\
329,808\end{array}$ \\
\hline
\end{tabular}

a Operated 4 months.

- Operated 9 months.

Recent dividends have been as follows:

Dividends paid by United Verde Extension Mining Co., 1916-1924

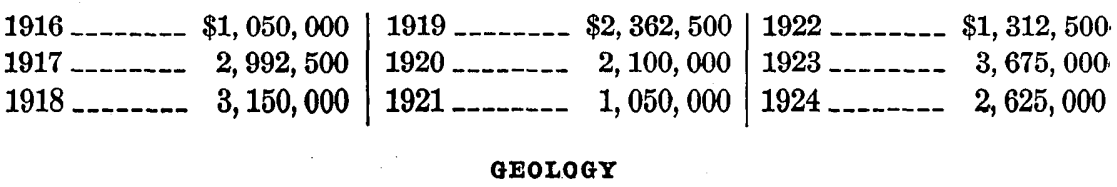

As the U. V. X. property lies on the slope below the main fault, the ore bodies found thus far are entirely in the hanging wall of this dislocation. The fault itself has been exposed in various parts of the workings, including the 1,700-foot level. The pre-Cambrian rocks were encountered at a depth of 670 feet. In the upper levels these rocks are mainly schistose, reddish, and more or less oxidized. On the lower levels, to which oxidation has not penetrated, the prevailing rock is greenstone schist, intruded in places by "quartz porphyry." "Quartz porphyry" was observed underneath the ore body where it approaches the fault and at several other places. Apparently the big ore body is almost wholly in this rock. Strong kaolinization was noted at the edges of the ore body. Diorite is seen only in a small area on the 1,200-foot level.

The predominant rock is thus a greenstone schist, very similar to that of other parts of the Jerome district. It has a dull dark-green 
color and its individual minerals are rarely visible. The schistosity is well defined, but the rock is not fissile.

The "quartz porphyry," which undoubtedly is intrusive into the greenstone, is as shown by a specimen from the 1,650-foot level a purplish-gray schistose rock in which small feldspar crystals and many quartz phenocrysts may be seen; the quartz crystals average perhaps 1 to 2 millimeters in diameter. Though now holocrystalline it presents the appearance of a rock solidified within a short distance of the surface.

J. R. Finlay ${ }^{37}$ states that the "quartz porphyry" forms a large irregular mass, the outlines of which are but vaguely known. It extends along an approximately east-west course from a point southwest of the United Verde to and beyond the Texas shaft, a distance of $21 / 2$ miles.

The north boundary of this mass cuts across the schistosity of the greenstone nearly at right angles and forms a rude plane which dips generally northward at an angle of perhaps $60^{\circ} . * * *$ This porphyry, which in its center approaches a granite in texture, has been strongly sheared, and a pronounced schistosity has been developed in a large part of it. Some portions, however, especially in the southwestern part, have been much less affected by shearing and are still massive. * * * The schistosity has a strike of about N. $20^{\circ} \mathrm{W}$. and occurs in bands of greater or less intensity. So far as known at present the intrusions of Tinited Verde diorite do not penetrate into the mass of the quartz porphyry but seem to follow along its contact. Sometimes the diorite cuts across branching arms of the quartz porphyry and in places comes in contact with the main mass. * * * It would appear that the greenstones near the contact formed a weal zone, which was followed, at least in a general way, by the diorite intrusions. * * * The diorite is strikingly fresher than the older rocks, and the contrast between its massive structure and the extremely schistose parts of the quartz porphyry attracts immediate attention. * * All the known valuable ore bodies of the Jerome district occur in the greenstone schists which form the border of the quartz porphyry or are within the latter rock, within its periphery.

There is much jaspery material connected with the ore bodies. I have seen no definitely recognizable rocks of sedimentary origin.

The schistosity trends about N. $20^{\circ} \mathrm{W}$. and is not exactly parallel to the fault, which trends more northwesterly.

ORE BODIES

The main ore body was found about 900 feet south of the shafts, which are close together. The highest point of this body is at the 1,250 -foot level, or at an altitude of 3,650 feet, though lenses are found above this level. On the whole the shape of the ore body is

Eng. and Min. Jour., vol. 106, p. 562, Sept. 28, 1918. 
rounded; on the 1,400-foot level it measures about 440 feet from east to west and 269 feet from north to south. Above the 1,250-foot level the ore is replaced by leached siliceous material. Below the 1,400 -foot level it gradually tapers and approaches the main fault but again slopes east without reaching it..$^{38}$

From the ore body there extend two schistose and mineralized streaks about 150 feet apart, trending about N. $20^{\circ} \mathrm{W}$. One of these was found on the 1,200-foot level 500 feet south of the shaft; it extended for about 120 feet horizontally, and reached a little above the 1,100-foot level, but it was not found on the 1,400-foot level. Another of the smaller ore bodies was found near the Jerome-Verde line 500 feet west of the Edith shaft, in greenstone schist on the 1,200-foot level. Several fissures were crossed trending N. $45^{\circ} \mathrm{W}$, parallel to the main fault. In June, 1922, the drift showed 6 feet of ore containing chalcocite, cuprite, and native copper and averaging 40 per cent of copper. The ore body here trends nearly due north, and the rock adjacent to the ore is a reddish and soft, partly oxidized "quartz porphyry." The main fault is 300 feet distant to the west.

The siliceous capping above the 1,250-foot level has approximately the same outline as the ore body - that is, it measures about 500 by 300 feet. The sulphides come in sharply 50 feet below the 1,200-foot level. Immediately above the capping a raise would enter volcanic conglomerate and lava, the limestone being here eroded.

At one place a drift reaches the fault. Drag of chalcocite is found along the fault, but otherwise the ore lies flat 50 feet below the 1,200 -foot level.

On the 1,300-foot level the massive chalcocite ore is exposed. In a raise above this level the sharp line was exposed between the sooty chalcocite and the red oxidized rock. The material in the stopes averaged 15 per cent of silica and 45 per cent of massive pyrite. Smaller masses of sulphide ore have been stoped in places up to the 1,100 foot level. The 1,400-foot level shows the richest and widest ore. On the northwest side of the ore body lenses begin. The first comes within 40 feet of the main ore body and contains chalcocite and native copper. On the 1,300-foot level this lens is 400 feet long and 5 to 40 feet wide, and the ore from it averaged 40 per cent of copper. This lens was stoped up to the 1,100-foot level but was not so wide there. The rake or plunge is to the northwest. Where the ore

ss $\mathrm{J}$. R. Finlay states that the great ore body lies apparently at the intersection of two mineralized faults, one striking N. $65^{\circ} \mathrm{E}$. and the otber $\mathrm{N} .70^{\circ} \mathrm{W}$. I have not seen these faults, but Mr. $O$. Wenström states that one of them, the Florenzia fault, is well exposed in the workings of the Jerome Verde Development Co. It strikes N. $70^{\circ}$ E. and dips $80^{\circ}$ SSE. The U. V. X. ore body lies in the angle between the Florenzia and Verde faults. 
is poorer pyrite appears, and the grade may descend to 3 or 4 per cent of copper. Rich ore was found below this point, on the 1,400 -foot level.

On the 1,500-foot level the rocks are decidedly harder and more compact than above. At one point on the 1,500-foot level the ore body almost touches the fault. In the stopes above this level a sharp contact with kaolinized schist was observed. The ore contained soft chalcocite and averaged 10 per cent of copper. On the 1,500 -foot level ore is also obtained in lenses northwest of the main ore body by raising some distance above the level.

The fault is well exposed on this level. Low-grade massive pyritic ore is shown at some places between the lenses and the fault. A body of pyrite 60 feet wide lies against the fault and is sheeted by it. Parts of this body are said to average 3 per cent of copper. Most of the output of the mine in June, 1922, came from the 1,500-foot level.

On the 1,700-foot level the lower part of the main ore body apparently tends to dip away from the fault. Prospecting operations were in progress 700 feet west of the shaft in search of the Jerome Verde ore body seen on the 1,200-foot level.

\section{THE ORE}

No complete study of the ores has been attempted, as such a study would plainly require a detailed examination of the mine. On the whole, the composition is simple. Fine-grained cherty quartz with a little obviously very late calcite forms the gangue. There is much pyrite, though it is more or less concealed by the abundant chalcocite, which has probably replaced chalcopyrite and to some extent the pyrite. (See pl. 13, A.) Native copper is abundant in some stopes; apparently it is a later mineral, which, like the locally abundant cuprite, has developed from chalcocite. Covellite is of still more localized occurrence. Magnetite is found in places and appears to be later than pyrite. No chalcopyrite or sphalerite was found, nor would they be expected, in view of the extensive chalcocitization.

The capping is composed of a dense siliceous, cherty material, much of it red from hematite, and in part cavernous and cellular, showing the leaching of the sulphides. A distinct enrichment in silver is evident just above the line of the massive sulphides. Although the average chalcocite ore contains less than 2 ounces of silver to the ton (considerably less than the ore of the United Verde), the material for about 7 feet above the sulphide ore con- 
tains from 10 to 12 ounces and has rich spots containing as much as 100 ounces to the ${ }^{39}$

The pyrite is massive and fine grained and forms aggregates embedded in fine-grained quartz. Many of these grains are sharply defined cubes.

The chalcocite is in part sooty and soft, but in many stopes it is also massive and of dark-gray color and metallic luster.

The cuprite is in part massive, in part crystallized in combined cube and dodecahedron, also in part in cavities crystallized as chalcotrichite.

Large specimens of massive covellite were obtained.

A specimen of low-grade ore collected above the 1,300-foot level shows a streaky hard flinty rock of dark color consisting of parallel but irregular bands of extremely fine-grained pyrite in dark cherty gangue. Under the microscope it consists of a fine-grained aggregate of quartz in which each minute and ill-defined grain shows undulous extinction. Grains and small cubes of pyrite are embedded in this jaspery material, which I take to be the product of a replacement of schist. Veinlets and irregular masses of distinctly later, coarsergrained quartz are contained in the jaspery quartz-pyrite mass, and in some of these veinlets small grains of magnetite occur, the magnetite being thus undoubtedly later than the pyrite.

The ore contains about 10 per cent of chalcocite, which in part replaces the pyrite and in part occurs between the grains of pyrite and quartz, giving the impression of having replaced an earlier sulphide, probably chalcopyrite. To some extent the chalcocite also replaces quartz. (See pl. 13, B.)

\section{ORIGIN OF THE ORE}

It is not necessary to argue at great lengths regarding the original character of this remarkable ore body. Contained in schistose preCambrian rocks and overlain by the Paleozoic sedimentary column, it is clearly pre-Cambrian and in its origin identical with the other ore bodies in the district, particularly that of the United Verde mine. It replaces greenstone schist and quartz porphyry; it was formed after the schistosity had been imposed upon this rock and the earlier greenstone. Its relations to the probably later diorite remain somewhat clouded. The site of the main ore body may have been determined, as Finlay suggests, by the intersection of two mineralized shear zones. Some of the smaller ore bodies certainly seem to follow the general direction of schistosity. There are in the mine large masses of pyritic schist, which in places go over into massive pyrite, as in the United Verde mine.

I am informed that in 1923 a considerable body of gold ore, a sugary, evidently leached quartz with $\$ 15$ in gold to the ton, was encountered on the 1,200 -foot level about $\mathbf{5 0 0}$ feet northwest of the bonanza and above the general level of the chalcocite zone. 


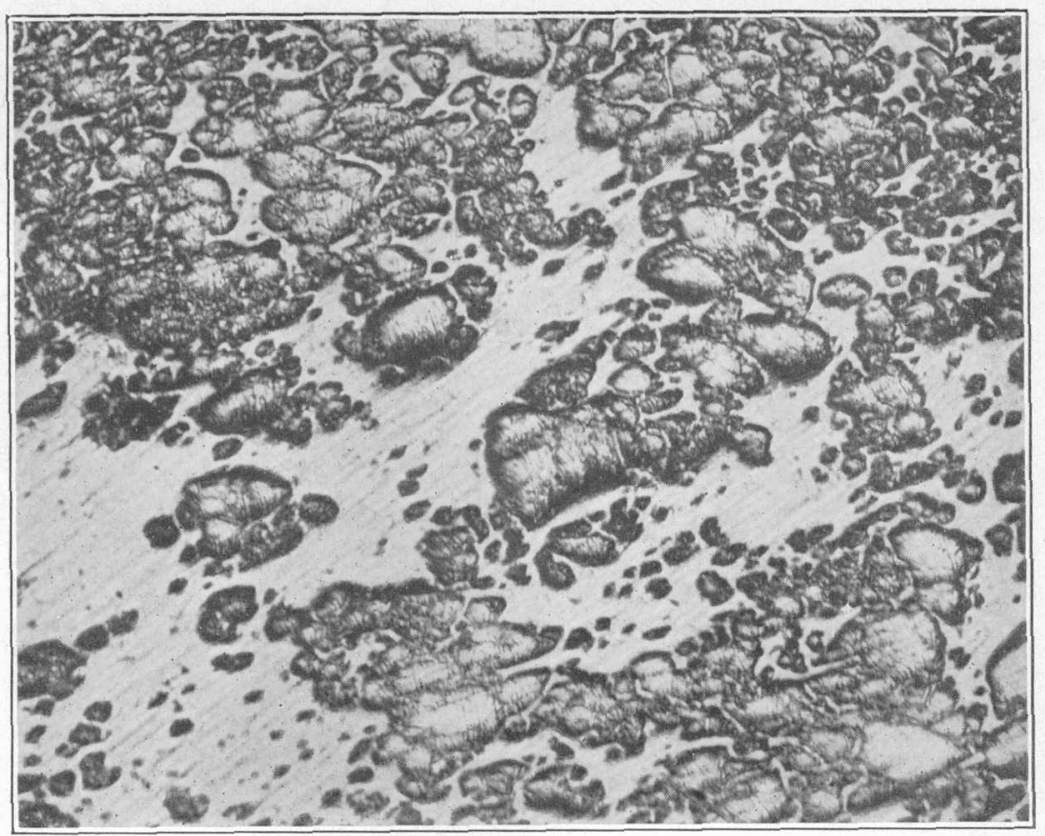

A. ORE FROM 1,650-FOOT LEVEL

Pyrite (rounded grains, strong relief) fractured and replaced by chalcocite (white)

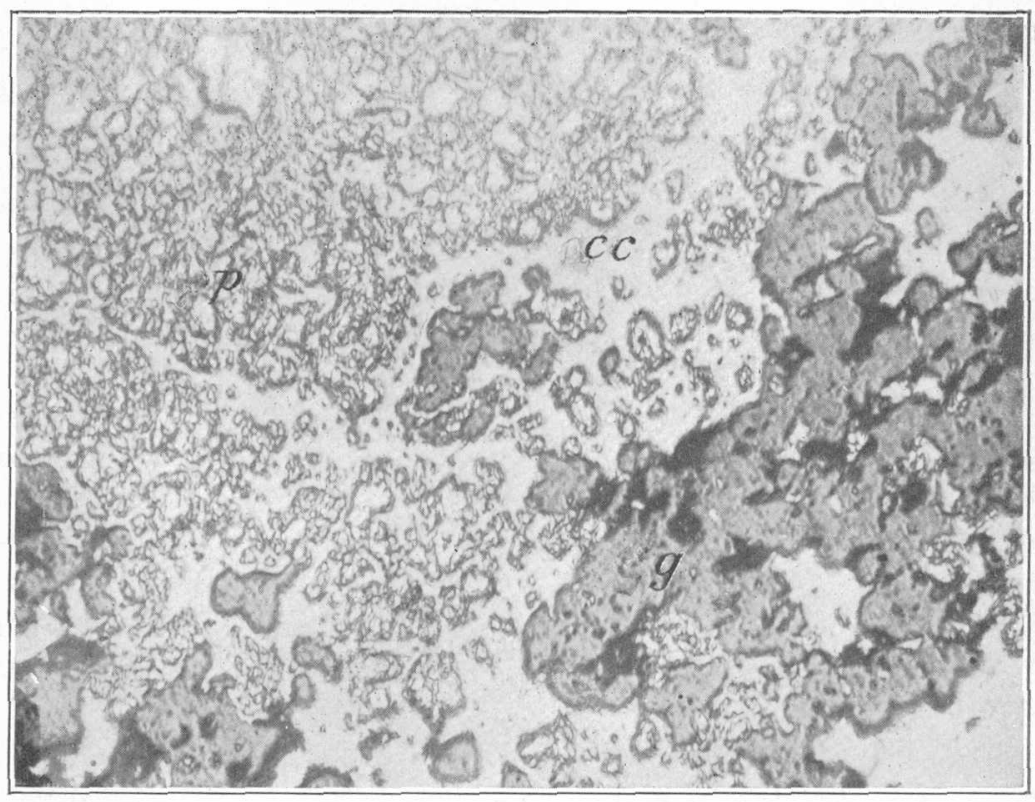

$B$. ORE FROM SAME SPECIMEN AS $A$

Chalcocite $(c c)$ replacing pyrite $(p)$ and gangue $(g)$

Photomicrographs of POLISHED SECTIONS SHOWING ORE FROM UNITED VERDE EXTENSION MINE 


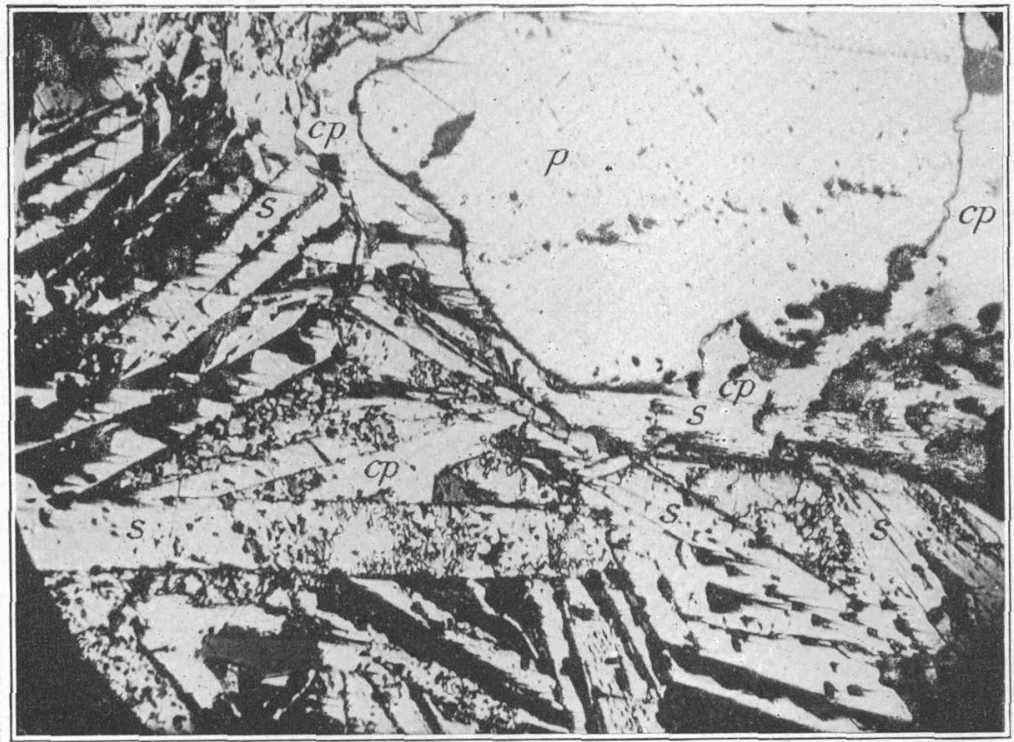

A. ORE FROM CASH MINE

Pyrite $(p)$, chalcopyrite $(c D)$, and specularite $(s)$. The specularite incloses irregular areas of magnetite. Pits in specimen show black. Enlarged 110 diameters

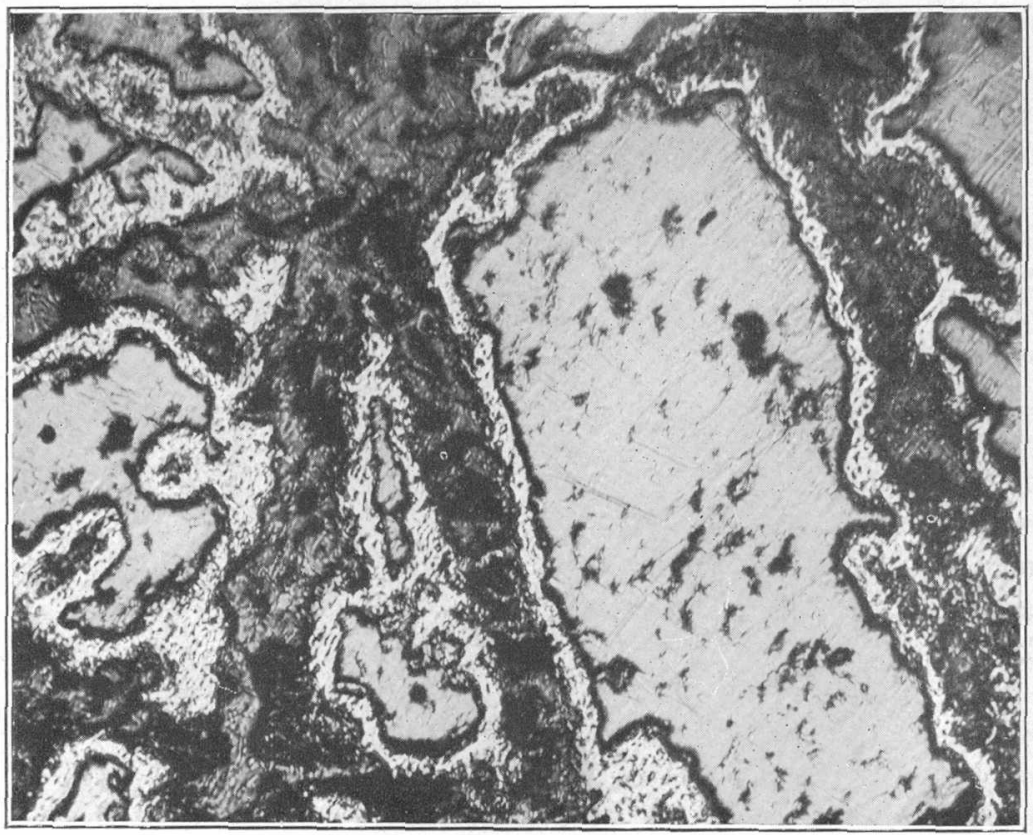

B. OXIDIZED ORE FROM COUGAR VEIN 75 FEET BELOW SURFACE

Sphalerite marginally replaced by argentite. Enlarged 130 diameters

PhotomicRographs OF POLISHED SECTIONS SHOWING ORES 
The suggestion has often been advanced that the large ore body may be the downfaulted upper part of that of the United Verde; but, as pointed out by Rickard and Finlay, this is improbable, because its trend and plunge are different and because its projection upward, after allowing for the 1,700-foot slip along the main fault, would bring it above the town of Jerome, or a long distance south or southeast of the United Verde body.

Nevertheless, it must be pointed out that lateral as well as vertical movement has certainly taken place along the fault and that this lateral movement has not yet been correctly determined. This ore body may therefore originally have been closer to or farther away from the United Verde than is indicated by a straight normal fault with its slip parallel to the dip.

The ore of the United Verde Extension differs materially from that of the United Verde. It contains no chalcopyrite nor sphalerite. Its principal ore mineral is massive or sooty chalcocite, with incidental native copper and cuprite. It contains, however, much pyrite-more than is apparent at first glance. It is a very high grade chalcocite ore. Much of the ore shipped averaged 27 per cent of copper; the ore smelted in the local works averaged from 15 to 22 per cent. The body contains many lean bars with much pyrite, dense streaky masses in dark jaspery quartz, and more or less chalcocite. The ore on the lower levels probably averages of lower grade than that near the siliceous and leached capping. I have been told that the copper content of the ore on the 1,500-foot level averages 15 per cent.

The siliceous capping extends for 400 feet below the basal Paleozoic sandstone. Then along a horizontal plane rich chalcocite ores begin, reaching their maximum development on the 1,400-foot level and gradually contracting below. If chalcopyrite occurs in the lower levels I have not seen it.

All these relations summarized here prove beyond doubt that we have to do with a normal chalcocite zone due to descending surface waters. It is wholly impossible that the chalcocitization was effected after the thick Paleozoic blanket had been deposited, and the inevitable conclusion, already pointed out by the men who have written on the district, is that the ore body of the United Verde Extension represents a chalcocite zone of pre-Cambrian age.

For untold ages before the transgression of the Paleozoic sea the rocks and deposits were subjected to oxidation by descending waters, which decomposed the silicates and sulphides and allowed the copper sulphate to percolate slowly downward to a level where it replaced the unaltered pyrite by chalcocite. The slow erosion

68508-26-7 
could not keep step with this process; gradually the leached zone became thicker and the chalcocite zone deeper and richer. No oxidized copper ores could persist in the leached zone.

In imagination we can see the red wastes, bare of vegetation and covered by deep soil, worn down almost to a plain by rivers and gulches and sheet floods. This plain extended under a burning sun in an arid climate, with a deep water level, where a million years or so still farther back in time imposing mountain ranges had been piled up by lateral pressure and by mighty intrusions of granite, now termed the Bradshaw granite.

Again for countless revolutions around the sun the sea swept over this ground, receding and transgressing. Thousands of feet of sediments weighed heavily on the deposit. Action by descending surface water ceased, and quiet reigned.

The earth had grown older. Forests covered the lands, and the evolution of life into intelligence was well on its way when the waters receded from the place where the bonanza was resting. Uplift of the sea bottom started erosion. Destruction followed deposition, and between the erosion and the rending, settling motion of the crust the sunburnt top of the pre-Cambrian again saw light. Before the ever-recurring cycles of oxidation, decomposition, and destruction could reach it again, and before erosion could scatter it over the plains, evolution had produced intelligence. Intelligence needed metals. Intelligence found the bonanza.

\section{JEROME-VERDE DEVELOPMENT CO.}

The Jerome-Verde Development Co. was incorporated in 1921 to take over the property of the Jerome-Verde Copper Co. It holds 28 patented claims to the north and northeast of the town of Jerome, of which the most promising are those adjoining the Little Daisy group of the United Verde Extension Co.

Earlier work comprised the Columbia shaft, in the southern part of the property, 1,000 feet southeast of the Edith shaft of the U. V. X. The Columbia shaft is 1,060 feet deep and connects with 12,000 feet of workings, mainly on the 1,100-foot level, which is equivalent to the 1,400-foot U. V. X. level. The altitude of the collar is 4,749 feet, and it is said that the pre-Cambrian rocks were encountered at a depth of 426 feet. The property lies on the east side of the fault, and attempts have been made in cooperation with the United Verde Extension Co. to discover ore bodies on this side which may be connected with those of the U. V. X. mine. In 1919 and 1920 considerable ore was shipped to the Humboldt smelter. Weed ${ }^{40}$ estimates the amount at 10,000 tons, containing

to Weed, W. H., Mines Handbook, 1922, p. 309. 
from 8 to 12 per cent of copper. This ore came from an ore body extending on a slip about parallel to the main fault from a point 30 feet above the 1,000-foot level for 250 feet along the dip upward. This ore body was stoped to the U. V. X. boundary.

In 1922 operations were resumed from the United Verde Extension 1,100,1,400 (equal to the 1,100-foot from Columbia shaft), and 1,700-foot levels, the ground explored being principally under the Maintop and Signal claims. In 1922 3,060 feet of development work was done, but thus far no valuable ore bodies have been discovered.

In his report for 1922 Olof Wenström, the engineer of the company, states that earlier work on the 800-foot level (Edith shaft), at a small depth below the sedimentary capping, had opened a large body of copper-bearing but leached material on the Maintop claim, which was held to indicate the existence of ore below.

The sheared zone of schist to the southeast within the U. V. X. property has been found to contain valuable ore bodies on several levels. These ore bodies are grouped along two "veins" about 200 feet apart, and one on the "West vein" extends into the Maintop claim for a short distance between the 1,100 and 1,300 foot levels. The object of the exploration of the upper as well as of the lower levels is to trace the northwest extension of these two ore zones. Down to the 1,400-foot Edith level the mineralized material encountered. is mostly oxidized and leached, the most favorable horizons evidently being below this level. Drifts on the 1,700-foot Edith level have now explored the southern part of the Maintop claim and the southwestern part of the Signal claim. The main fault, dipping $60^{\circ} \mathrm{NE}$., has been cut in two crosscuts on the 1,700-foot level at points 230 feet apart. A sheared zone of "quartz porphyry" and greenstone, about 150 feet wide, extends along the hanging-wall side of the fault; on the footwall side the rock is massive "quartz porphyry." The schist is locally pyritized and contains a few veinlets of chalcopyrite.

Wenström says:

During my visit to the U. V. X. mine in June, 1922, the ore body close to the line of the Jerome Verde on the 1,200-foot level had just been struck, showing 6 feet of 40 per cent ore in quartz porphyry, but apparently it did not extend far into the latter property.

The workings on the 1,700-foot level, in which the continuation downward of this ore body was looked for, were also visited, but nothing of value had thus far been encountered. 
DUNDEE-ARIZONA COPPER CO.

The property of the Dundee-Arizona Copper Co. consists of two claims between the Jerome Verde and the United Verde Extension, a short distance east of and below the town of Jerome.

The deposit is unusual and interesting. It consists of a gravel bed in a stream of Tertiary age which had its headwaters, before the faulting, in the vicinity of the present United Verde mine, or somewhat north of it. This gravel bed, or conglomerate, contains boulders as large as 2 feet in diameter of basalt and limestone and is impregnated with copper to a width of 900 feet and a depth of 5 feet. The impregnation is not uniform, however. It is claimed that 69,000 tons of this ore that will average 4 to 5 per cent of copper is developed. Experiments with leaching processes have been carried on, and several carloads of this ore have been shipped. This conglomerate crops out boldly along Deception Gulch at an altitude of about 4,500 feet, 150 feet above the bottom of the gulch.

The shaft of the property is at an altitude of about 4,600 feet. It was sunk in 1920 and passed through basalt conglomerate into tilted limestone and finally into the underlying pre-Cambrian rocks. The shaft is 950 feet deep. The lateral developments on the 950 -foot level amount to 2,750 feet. The shaft passed through 100 feet of conglomerate and 10 feet of copper-bearing conglomerate. At 500 feet below the collar it reached the base of the Tapeats sandstone. It was sunk 450 feet farther in pre-Cambrian rocks.

The conglomerate, which rests on limestone, consists of abundant boulders and pebbles of basalt and limestone, well worn and rounded. There are also many well-polished boulders of a hard limonitequartz mixture, with some hematite, which evidently came from the outcrops of the United Verde ore body.

The ore mineral is almost exclusively a blue-green chrysocolla, that coats and replaces the pebbles, both of limestone and basalt. Similar stains and coatings of the same mineral are found on the joints of the limestone, which here forms the bedrock of the Tertiary gulch.

The chrysocolla forms a mammillary coating on the pebbles. Under the microscope it shows evidences of colloidal deposition, indicated by concentric lines. Some chalcedony is associated with the chrysocolla. The chrysocolla has a distinct pleochroism ranging 'between pale green and clear bluish green, the latter when the fibers are parallel to the principal section of the microscope. The interference colors are bright and of the first and second orders. The chrysocolla also replaces both limestone and basalt, forming a brightgreen shell on the outside or even replacing some pebbles completely. The copper-bearing solutions must have carried cupric sulphate 
with a great abundance of silica. Only in this way can the replacement of limestone by chrysocolla be explained. In places the chrysocolla is stained deep brown, probably by manganese. Fissures in the limestone carry some malachite or chrysocolla and strike N. $45^{\circ}$ E.

\section{COPPER CHIEF MINING CO.}

The Copper Chief is one of the few producing mines in the district. It consists of 21 claims 3 miles south-southeast of Jerome, and the lower tunnel is at an altitude of 5,300 feet. The developments consist of a shaft 350 feet deep, with 2,225 feet of drifts on various levels. The equipment includes a cyanide mill having a capacity of 125 tons. The total output from 1916 to 1918 (by the Hayden Leasing Co.) was 71,849 tons of ore, which returned $\$ 875,800$, or about $\$ 12$ a ton. The mine is accessible by trail from Jerome or by wagon road by way of the Verde Valley, 12 miles from Jerome.

The rocks include greenstone and a flat-lying granite porphyry. The greenstone is cut by several porphyry dikes striking north. The deposit appears to lie in an east-west shear zone between porphyry and greenstone, the greenstone showing only slight schistosity.

The ore body crops out on the north side of Silver Spring Gulch 200 feet above the road, at an altitude of 5,750 feet. The outcrop is divided between the Copper Chief and the adjoining Iron King claim of the Equator Mining \& Smelting Co. The ore was oxidized down to 230 feet below the collar of the shaft. It then turned to sulphides, now wholly in Equator ground, and contracted to the vanishing point above the lowest workings, at an altitude of 5,400 feet. However, during 1922, in the lowest tunnel, about on the level with the mine office, massive sulphides with some copper were encountered in the breast, 1,200 feet from the portal.

Weed ${ }^{41}$ says that less than half of the oxidized material was ore, and that about 15 per cent of the sulphide body could be mined at a profit. The tunnel, driven northward, cuts across greenstone with dikes of granite porphyry, also some jaspery material. The conditions are complicated by a rather remarkable flat fault, which is exposed in the tunnel and is believed to continue southward to the Grand Island property. The lower part of the ore body may therefore have been faulted. In places there is a little quartz on the flat fault. L. E. Reber, jr., believes that the throw is considerable, perhaps 300 feet.

The oxidized ore is siliceous and contains a little copper carbonate and in places cerusite, indicating that galena must have occurred in the primary ore. The ore milled yielded 0.3 ounce of gold and about 6 ounces of silver to the ton.

a Weed, W. H., Mines Handbook, vol. 13, p. 400, 1918. 
The main sulphide body is above the lowest tunnel and has a northerly dip of $45^{\circ}$. It was exposed 50 feet above the tunnel level and forms a large mass about 80 feet wide and several hundred feet long, mostly of low grade. The footwall dips $30^{\circ}$ to $45^{\circ}$; the hanging wall is nearly vertical. In places the low-grade pyrite contains chalcopyrite and is banded by streaks of sphalerite. In the stopes 50 feet above the tunnel the pyritic ore near the footwall contains thin streaks of chalcocite. The ore in the lowest tunnel is a dense pyrite with veinlets of chalcopyrite and sphalerite. (See pl. $10, A$.) The sulphides are cut by very thin veinlets of calcite. (For further description see p. 34.) The line between the sulphide and the oxidized ore, as shown in these stopes, 100 feet above the tunnel, is extremely sharp. The pyrite is sandy, and just above this is a black powdery mass, at most 5 feet thick, which contains some chalcocite and was mined during the time of visit in 1922. This chalcocite ore is reported to contain as much as 40 ounces of silver and 0.75 ounce of gold to the ton. The copper content is only about 1 or 2 per cent, in part as chalcocite, in part as carbonate. The sulphide ore was mined by the Equator Co. in 1905 and was smelted in a local plant, which is still standing. The Copper Chief Co. also mined some sulphide ore and shipped it to the Humboldt smelter.

\section{EQUATOR MINING \& SMELTING CO.}

The property of the Equator Mining \& Smelting Co., owned by Senator Clark, is sufficiently described above in connection with the Copper Chief property.

\section{SHEA COPPER CO.}

The property of the Shea Copper Co. is just south of the Copper Chief, at about the same altitude, and consists of five claims. It is developed by an incline sunk on the dip of the vein for 600 feet to the tunnel level and for 200 feet.below this level. The workings on the several levels aggregate about 5,000 feet. The mine was idle when visited, but it is reported that work has since been resumed. Silver-copper ore has been shipped from this mine to the United Verde Extension smelter at Clemenceau.

The deposit is a vein contained in a dark-green, very dense and massive dioritic rock, the original character of which is now scarcely recognizable on account of the development of chlorite, epidote, sericite, and quartz. This rock is cut by dikes, of medium-grained pinkish granite, the feldspars of which are almost wholly sericitized. Next to the vein the sericitization has converted the rocks to a dense pale yellowish-brown material consisting of residual quartz, full of fluid inclusions, and wholly sericitized feldspars, 
With the sericite are grains of carbonate, evidently both ankerite and calcite. Small crystals of pyrite are contained in this rock. The vein strikes east and dips $30^{\circ}-50^{\circ} \mathrm{S}$., the dip increasing with the depth. It pinches and swells; its maximum width is 5 or 6 feet. The ore structure is rudely banded, the quartz containing bands of siderite and ankerite with narrower streaks of sulphides.

The sulphides consist of pyrite, tetrahedrite, chalcopyrite, and arsenopyrite, also a little galena. In the best part of the ore lens, west of the shaft on the 200-foot level, the banded tetrahedrite ore contained as much as 100 ounces of silver to the ton. A few carloads of this ore were shipped. Quartz predominates and is white, coarsely crystalline, and almost glassy. Large aggregates of siderite and ankerite are present. The tetrahedrite contains some arsenic.

The lowest level was not visited but is said to show a vein 1 to $21 / 2$ feet wide, from which some good assays were obtained.

The flat fault observed in the Copper Chief and in the Grand Island is believed by L. E. Reber, jr., to cross the vein just at the collar, where the vein shows shearing and flattens.

\section{PROSPECTING OPERATIONS IN THE VERIE DISTRICT}

An enormous amount of exploratory work has been done south of Jerome in the hope of finding ore bodies similar to those at Jerome. The aggregate cost of this work runs into millions of dollars. Most of these properties are now closed and inaccessible, and much of the following information is derived from Weed..$^{42}$

The Grand Island Mining Co. owns 14 claims in the southern part of: the Verde district, south of the Shea mine. The developments consist of a shaft 520 feet deep, with a southwest crosscut on the 200 -foot level. The claims show a quartz vein 4 feet wide on the surface and 8 feet wide on the 200 -foot level in porphyry schist and sheared diorite. The country rock consists of diorite and greenstone. Some ore was found in a flat fault near the surface, the same fault that passes through the Shea property.

The Jerome Copper Co. owns five claims north and west of the Green Monster property, which are developed by a tunnel 1,025 feet long and by 1,800 feet of crosscuts and drifts. The rocks comprise diorite and greenstone schist. There is also a large outcrop of jaspery or cherty material on the property. The diorite and schist contact is said to be exposed about 860 feet from the portal.

The Green Monster Mining Co.'s property of 68 claims is mainly $\delta$ to 4 miles southeast of Jerome, but two of the claims are 1 mile south of Jerome. The main shaft, 930 feet deep, is said to bottom in diorite. On the 500-foot level the northwest crosscut reached the

a Mines Handbook, vol. 15, 1922. 
Revenue vein and at 600 feet encountered the "quartz porphyry" contact, which contained some chalcocite and chalcopyrite in a highly kaolinized leached zone. The Gorge tunnel is on the Cliff claim, north of the Equator property, and was once owned by the George A. Treadwell Mining Co. The tract contains several large jasper outcrops, and that of the Cliff claim shows commercial ore at the surface. The Cliff shaft connects with the Gorge tunnel. Drifts started both east and west on a mineralized contact of "quartz porphyry," and diorite developed a low-grade ore body which, 100 feet below in the tunnel, seemed to be bottoming in "quartz porphyry." Work on the property was discontinued in 1919. The Brookshire tunnel, in the northern part of the property, is 3,000 feet long on the contact of greenstone and diorite belonging to the same complex. Quartz with much chalcopyrite is exposed on the fump.

The Jerome Del Monte Copper Co.'s property lies north of the Green Monster and includes 41 claims, mainly east of the fault. A three-compartment shaft sunk in limestone had attained a depth of 500 feet in 1917. Much water was encountered.

The Gadsden Copper Co. owns 39 claims west of the Jerome Del Monte and about 11/2 miles southeast of Jerome. The extensive developments comprise a four-compartment shaft 1,200 feet deep, with 5,619 feet of drifts and crosscuts. The shaft is sunk in limestone east of the fault and reached schist at a depth of 400 feet. The crosscut west on the 1,200-foot level cut the Jessie fault 1,800 feet northwest of the shaft and in a southwest drift opened up ore running 8 to 10 per cent of copper, with 3 ounces silver and $\$ 3$ in gold to the ton. Operations were discontinued in 1920.

The Verde Combination Copper Co. has 33 claims south of Mescal Canyon, 1 mile southeast of Jerome, and west of the Gadsden. The developments comprise a shaft 1,300 feet deep sunk in greenstone a short distance west of the Jessie fault. Some work was in progress in 1922. The shaft connects with extensive workings in Mescal tunnel, which shows the great Verde fault, also 2 feet of 5 per cent copper ore in a fissure vein, and two promising contacts with stringers of copper ore. The old workings at the south end of the tract include two shafts, 640 and 500 feet deep, showing diorite with stringers of copper ore, and a 75-foot tunnel that opens a 3 -foot quartz vein.

The Pittsburgh-Jerome Mining Co. owns 21 claims on the upper part of Mescal Gulch, west of the property of the Verde Combination Copper Co. The developments consist of a tunnel 1,279 feet long and a connecting shaft 900 feet deep, sunk 1,000 feet west of the portal. The rocks all the way up Mescal Canyon consist of a greenstone complex; the schistosity strikes N. $20^{\circ}$ W. The bedding 
of the volcanic agglomerate is visible in places, dipping $45^{\circ} \mathrm{N}$. Several veins that were cut were said to show leached ore averaging 2 per cent of copper. On the dump is some malachite ore in bleached kaolinized rock and stringers of massive chalcocite of primary appearance. The management hoped to find better ore below the water level, which apparently was not reached. The altitude of the tunnel is about 5,400 feet. . Prospecting operations were carried on here for 16 years at great expense, but work ceased in 1921 .

The Verde Venture Mining Co. sunk a shaft in greenstone a short distance below the Pittsburgh-Jerome tunnel but found no ore.

The Cleopatra Mining Co., controlled by the United Verde Copper Co., has 11 claims on Cleopatra Mountain adjoining Deception Gulch half a mile south of Jerome. The workings are extensive. The principal adit is the Dillon tunnel, 3,200 feet long. The rocks are greenstone and "quartz porphyry" containing several more or less irregular veins of copper ore, in part with a high percentage of copper and silver. A body of sulphide ore was found north of the gulch on the Silent claim. Some of this ore was shipped, and a small smelter was erected at one time in the lower part of Deception Gulch, above the fault. The Dillon tunnel passes northward into the property of the Hull Copper Co.

The Calumet \& Jerome Copper Co. owns seven claims on Deception Gulch, adjoining the Cleopatra property on the southeast. The developments include a vertical shaft 600 feet deep on the Remington claim and several tunnels. A crosscut is said to extend 1,800 feet west from the 600 -foot level, mainly in greenstone schist. The shaft is sunk through the covering basalt and is said to pass through the main fault into mineralized greenstone schist. Headings on the 600-foot level are said to show schist impregnated with pyrite and chalcopyrite. Good indications, consisting in chloritic schist rich in chalcopyrite, were reported in 1922 . The total underground sworkings are said to amount to 7,000 feet.

The Verde Central Mines (Inc.) ${ }^{43}$ was prospecting actively in 1922 on its property of 20 claims on upper Deception Gulch, about a mile southwest of Jerome. The principal workings consist of a $60^{\circ}$ inclined shaft in Deception Gulch near the wagon road from Jerome to Prescott, at an altitude of about 5,600 feet. The shaft is 800 feet deep on the incline and connects with four levels. The workings aggregate 2,000 feet. The shaft follows a fault vein all the way down, with bunches of quartz and local copper staining and more or less pyrite and chalcopyrite. A red gouge accompanies the fault. The country rock is greenstone with intrusive tongues of

\footnotetext{
as Studied in detail by P. C. Benedict (thesis for degree of M. S., Massachusetts Institute of Technology, Cambridge, Mass.).

$68508-26-8$
} 
quartz porphyry, both more or less schistose and difficult to separate. The vein strikes N. $45^{\circ}-60^{\circ} \mathrm{W}$. and dips $60^{\circ} \mathrm{NE}$. The schistosity strikes N. $20^{\circ} \mathrm{W}$. In places there is much disseminated ore through 15 or 20 feet of schist, with a copper content of 1 to 3 per cent. There is little water and oxidation is general along the main fissures. On the 600 -foot level strongly mineralized rock was also found at the contact between greenstone and "quartz porphyry" 200 feet southwest of the shaft. This also appears to be a fault contact. On the whole the most favorable places to look for primary ore bodies in this vicinity are probably along contacts rather than along fault fissures, which in part may be of fairly recent or Tertiary age.

The former Verde Grande Copper Co., now reorganized as the Jerome-Grande Copper Co., has nine claims on the south slope of Smelter Hill, over the crest from the United Verde, which is on the north slope. The claims are on Deception Gulch at an altitude of 5,900 feet, a short distance above the Verde Central mine. The Jerome-Verde shaft is 838 feet deep and connects with about 2,000 feet of workings. The collar is in sedimentary slate, but the sump is said to be in diorite with some "quartz porphyry." It is said that on the 800-foot level, 560 feet from the shaft, a contact of diorite and "quartz porphyry" was cut, showing some pyrite and chalcopyrite. The mine was opened with the object of finding the southward extension of the United Verde ore bodies, but this object was not attained. The shaft has been idle for many years, and the buildings are decayed.

The property of the Hull Copper Co. lies west of the Cleopatra and comprises 21 claims. It is developed by the Dillon tunnel on the Cleopatra, which is over 5,000 feet long. The Dillon tunnel extends completely around two sides of the United Verde Copper Co.'s property. Some copper ore has been found on veinlets and slips, but little commercial ore seems to have been developed. Both the United Verde and the United Verde Extension companies appear to hold interests in this property.

The Arkansas \& Arizona Copper Co. owns 14 claims directly north of the property of the United Verde Copper Co. They are developed by a shaft 1,600 feet deep and by workings aggregating 6,000 feet. The shaft is reported to have passed through Tertiary basalt and limestone and to have struck the pre-Cambrian at a depth of 800 feet and continued in it to the bottom. The main fault was intersected on the 1,600-foot level 400 feet west of the shaft. Weed states that an ore body said to be 85 feet wide with chalcopyrite and some bornite was met on the 1,400-foot level. Others have stated that no ore was found. The rocks are said to be diorite and 
"quartz porphyry" cut by basalt dikes. The property is reported to be controlled by the United Verde Extension Co. It was closed in 1917. Its strategic position northeast of the United Verde invests it with some interest, as it seems possible that the United Verde ore bodies might in depth enter this ground.

The West United Verde Co.'s property of eight claims, formerly owned by the Jerome-Victor Extension Copper Co., adjoins that of the United Verde Copper Co. on the west. The developments are said to show "Ienticular ore bodies in diorite schist reported to be 3 to 19 feet wide and traceable for 2,000 feet." The Haynes shaft is 1,200 feet deep, with 2,000 feet of drifts on the 700 -foot level and 800 feet on the 1,200-foot level. No work has been done since 1914 and the property has now been taken over by the United Verde Extension Mining Co. Other informants aver that there was some rock showing pyrite on the 1,200-foot level but nothing else of value. Undoubtedly this property also has a strategic position.

The Jerome Superior Copper Co. owns a large area of 202 claims north of the United Verde. Here a shaft 900 feet deep is said to have an encouraging showing of chalcocite and copper-iron sulphides. The water in the shaft amounted to 160,000 gallons in 24 hours, or about 110 gallons a minute. The property was closed in 1920.

\section{BLACK HILLS DISTRICT}

The Black Hills district occupies the western slope of the Black Hills from Cherry Creek to Dewey and northward by Mingus Mountain to points a few miles north of Yaeger Canyon on the Jerome-Prescott automobile road. It includes many widely scattered prospects but practically only one producing mine, the Yaeger. Indications of copper are common but so far have been found disappointing. The whole southeastern part of the district is occupied by normal Bradshaw granite, its yellowish-white rounded outcrops visible from afar. This granite sends out embayments far northward, as at the Shylock mine, and south of Black Canyon there is a smaller isolated area of the same rock. The western foothills are occupied by a perșistent belt of fissile chloritic and sericitic schists trending northward from Texas Gulch east of Dewey to Grapevine Gulch, the Shylock mine, the Yaeger mine, and northward. Adjoining this schist is a parallel belt in which the "greenstone complex" of altered amphibolitic rocks predominates, with smaller inclusions of slate and jasper. 
Copper, lead, gold, and silver produced in Black Hills district, 1904-1923

[Compiled by V. C. Heikes, U. S. Geological Survey]

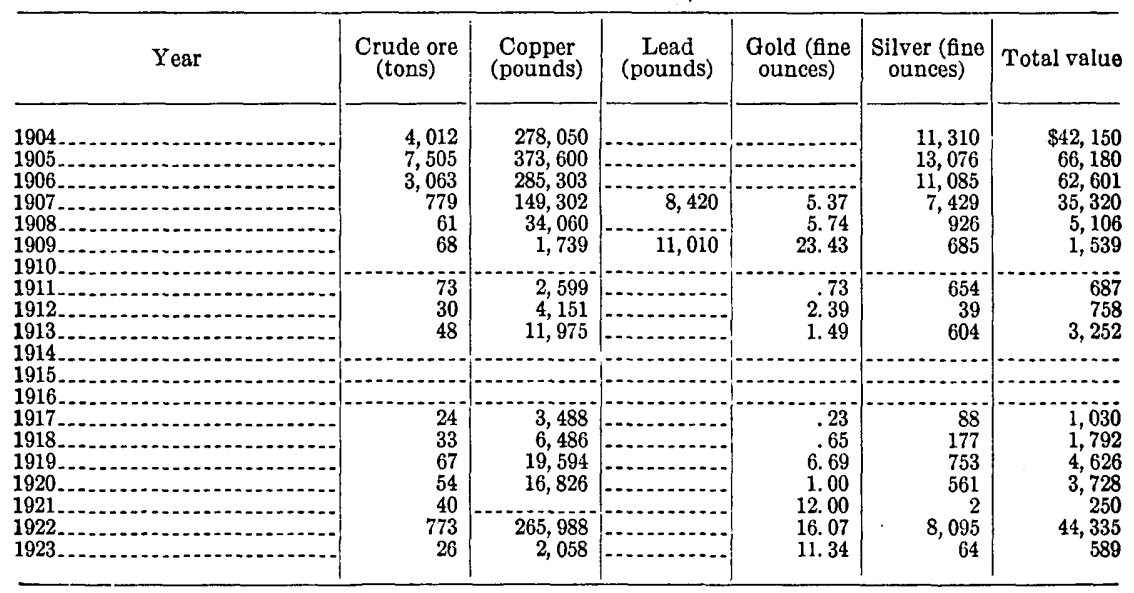

\section{YAEGER MINE}

The Yaeger mine, in the western foothills of the Black Hills about a mile south of the road from Prescott to Jerome, at an altjtude of 5,400 feet, was idle in 1922, except for some shipments of rich copper ore from the dump. For many years copper ore has been shipped from this deposit. It is now the property of the Shannon Copper Co., A. L. Ferris, manager. Up to 1919 the yield is said to be $9,627,987$ pounds of copper, 2,466 ounces of gold, and 77,134 ounces of silver. ${ }^{44}$ The mine is developed by an inclined shaft to the 1,300-foot level, with drifts extending mostly to the east a maximum distance of 750 feet. In 1922, 800 tons of copper-silver ore was shipped to the Humboldt smelter. The property has been dismantled and all work discontinued.4a

The brown, brushy hills around the Yaeger mine are of complex structure. Below the mine white fissile sericitic schists crop out. At the mine is exposed a dioritic fine-grained rock showing veinlets of epidote and also veinlets of calcite and bornite; above the mine are vertical greenish slates striking due north and also much of a massive fragmental rock that is perhaps a diabase tuff. The "diorite" shows in thin section as a somewhat sheared diorite porphyry with large phenocrysts of oligoclase-andesine in a trachytic groundmass of minute feldspar laths. There is a great deal of secondary chlorite, epidote, and calcite.

The deposit is a fissure vein striking east and having a dip of $35^{\circ} \mathrm{S}$. The width is as much as 7 feet; in places there was 3 feet of clear bornite. The ore contains calcite, quartz, bornite, and ten-

\$ Weed, W. H., Mines Handbook, 1922, p. 390.

44 U. S. Geol. Survey Mineral Resources, 1922, pt. 1, p. 516, 1924. 
nantite, with a little pyrite. There is some secondary chalcocite, and also fine azurite and malachite. The structure of the ore is mainly massive, with rather large aggregates of both bornite and tennantite. In places these two minerals are intergrown. More or less oxidized ore occurs near the surface. There is no chalcocite zone, properly so called. A polished section of the rich ore shows quartz (oldest), tennantite, partly replaced by bornite, and the bornite in turn cut by narrow veinlets of chalcopyrite. The mine makes about 18,000 gallons of water a day. The ore is said to contain 0.65 ounce of silver to 1 per cent of copper. Much of the ore has been of high grade. The ore shoot pitches to the east beginning near the collar of the shaft; it is apparently. 200 to 300 feet long in the middle levels but becomes small on the 1,300 -foot level.

The composition of the ore is unusual, and there is no definite evidence of the age of the deposit. Probably it is pre-Cambrian.

\section{SHYLOCK MINE}

The Shylock mine, idle for many years, is in the eastern foothills of the Black Hills, 4 miles due south of the Yaeger mine. It is accessible by an old road from Grapevine Gulch. The altitude is 5,800 feet. The mine is developed by an inclined shaft said to be 1,500 feet deep. Yavapai slates, in places fissile, form the principal country rock; an embayment of the main Bradshaw granite area reaches up from the south nearly to the mine. There are also greenstone schists in the vicinity. The Shylock shaft appears to be sunk on a vein striking east-northeast and dipping $60^{\circ} \mathrm{S}$. To judge from the dump the ore contained quartz, tetrahedrite, galena, and sphalerite. It is not known whether any shipments were made.

Further information regarding the prospects in this vicinity has been kindly supplied by Mr. P. C. Benedict, of Jerome, who writes as follows:

Near the Shylock mine the Yavapai schist seems to be divisible into three parts :

1. The fissile sedimentary schists, brown or red, forming a continuous belt along the lowest foothills. The strike is northerly, the dip vertical. These phyllites contain some beds of sandstone and thin conglomerates, with steep dips.

2. A "greenstone" occupying the hills east of the Shylock and appearing again in Grapevine Creek, east of the granite contact. This is in part an andesite, in part perhaps a fine-grained diorite.

3. A sedimentary rock, apparently inclosed in greenstone, east of the granite contact on Grapevine Creek. It is a blocky dense rock of dark-brown color similar to the "bedded sediments" of the pre-Cambrian at Jerome. The bedding is flat, and the rocks contain thin strata of hematite. 
The Bradshaw granite in Grapevine Gulch is somewhat less acidic than usual and contains hornblende. The granite south of the Shylock mine shows aplitic border facies and aplite dikes.

The deposits are mainly quartz veins containing calcite or other carbonates, tetrahedrite, sphalerite, and galena. The strike of these veins is north-northeast or even northeast, the dip east or southeast from $50^{\circ}$ to $90^{\circ}$. They occur in granite or in the Yavapai schist.

The Shylock mine is developed by a shaft 1,053 feet deep on a dip of $60^{\circ}$, with drifts amounting to 2,000 feet. The water level is 200 feet below the surface. The gangue is mainly massive white quartz, with some ankerite, and the irregularly distributed ore minerals are tetrahedrite or tennantite, galena, and sphalerite. In part the ore is oxidized, and besides the usual products the presence of cinnabar was positively established. It is probably derived from the decomposition of a mercurial tetrahedrite and occurs as coatings and fillings of cracks. In the two upper accessible levels the width of the quartz reached 5 or 6 feet, and it was usually bordered by gouges. The deposit looks like a quartz lens pinching in both directions from the shaft. The quartz is generally poor, but some specimens rich in tetrahedrite gave higher assays, as much as 180 ounces a ton.

The Kansas, Money-Metal, and Bessie Belle prospects are located on similar tetrahedrite veins in fissile slate or in granite and show the same north-northeast strike. A somewhat similar mineralization occurs in the 'Thorne \& Sweeney prospect.

At the Cobalt shaft, sunk in greenstone with aplite dikes; about half a mile southeast of the Shylock mine, cobaltiferous arsenopyrite (danaite) has been found. The character of the deposit is uncertain, but it appeared to pinch out in depth.

\section{MINGUS MOUNTAIN COPPER CO.}

The property of the Mingus Mountain Copper Co. is in the Black Hills, 12 miles south of Jerome, at the head of Ash Creek, at an altitude of 6,400 feet. It has been idle for some years. The developments consist of four shafts, the deepest 430 feet deep, and 4,240 feet of workings. ${ }^{45}$ The deposit is said to be a vein striking northeast and dipping $60^{\circ} \mathrm{SE}$., in which the ore occurs in bunches and streaks, with good surface showings of oxidized ore. The property was not visited. Evidently the deposit is of a type similar to that of the Shea and Yaeger mines.

\section{BRINDLE PUP MINE}

One or two miles east of the Mingus Mountain Copper Co.'s property, on the south side of Black Canyon, at an altitude of 6,200 feet, are some decayed workings on a vein dipping east or southeast about $50^{\circ}$. The ore is massive and shows quartz, ankerite, pyrite, galena, and sphalerite. The country rock is granite, which near the vein shows chloritic alteration.

${ }^{45}$ Weed, W. H., Mines Handbook, 1922, p. 340. 
From the old wagon road from Jerome to Prescott a road, more or less passable for automobiles, leads up Ash Creek over granite with massive rounded outcrops. A few miles north of the main road it enters the greenstone complex, consisting of massive and schistose amphibolite and locally jaspery material with magnetite. A side gulch from the northwest leads up to the Black Warrior prospect, where two shafts have been sunk; the deeper one about 200 feet deep in a greenstone showing bunches of quartz, copper stains, and a little chalcopyrite.

\section{OTHER PROSPECTS}

The new road from Jerome to Prescott ascends and crosses the Paleozoic strata and, at the summit, the basaltic flows that cover them. The road then descends over the same formation and 2 miles from Carter's ranch enters the underlying pre-Cambrian greenstone and schist. At the bridge there is an interesting exposure of bedding : fine-grained rocks, apparently consisting of tuffaceous material, are interstratified with beds of greenstone, the whole series dipping $45^{\circ}$ E. Where Yaeger Canyon debouches into Lonesome Valley there is a belt of more or less fissile chloritic schist, but it is here largely covered by Quaternary débris. This same schist belt continues northward along the western base of the Black Hills and in several places shows copper stains indicating pyritic impregnations. Little prospecting has been done in this area, but 3 miles north of the road are a couple of old shafts in schist and agglomerate.

A series of low hills, with a greatest altitude of about 5,700 feet, rise out of Lonesome Valley 3 to 5 miles west of the point where the road emerges from Yaeger Canyon. They trend northward and are made up mainly of granite, variable in grain, locally schistose and red or yellowish. North of the point where the automobile road crosses Coyote Wash many prospect holes are seen in these hills. The most prominent line of outcrops appears at and north of Emmit's ranch. The veins are from 6 inches to 2 feet thick and contain glassy quartz, with small cubes of pyrite and a few copper stains. They strike N. $25^{\circ}-40^{\circ} \mathrm{W}$. An old engine foundation and a caved shaft were seen at Emmit's ranch. The veins are of the pre-Cambrian type and appear to have been prospected for gold. There are some indications of old placer work in Coyote Wash. It is not likely that these veins will yield rich returns.

North of Davis station on the now abandoned United Verde \& Pacific Railroad line the hills of the Tapeats sandstone begin to come down to the valley, and their flat-topped outlines covering red granite are seen far to the north and northwest. Three miles north- 
west of Davis, at the edge of the foothills, chloritic schists again appear, injected with granite. Some of these schists, as at Ford's copper prospect, show green stains, and shafts have been sunk in them.

Close by, 4 miles from Davis, is the "Peters silver mine," on what proves to be a pre-Cambrian quartz vein about 2 feet thick, contained in red sheared granite. The quartz carries a little pyrite, galena, and sphalerite as well as black streaks of felted tourmaline. This vicinity, with parts of the Black Hills adjacent on the east, is known as the Mineral Point mining district. Near Russell and Bodkin, stations farther east on the abandoned railroad, are other copper prospects in schistose rocks.

\section{CHERRY CREEK DISTRICT ${ }^{40}$}

\section{GEOLOGY}

The Cherry Creek district, which contains many gold-bearing veins, occupies the southeast corner of the Jerome quadrangle, where the Black Hills are crossed by the old wagon road from Prescott to Jerome. In this vicinity the main ridge drops off sharply toward the east with a descent of 2,500 feet in 2 miles. Cherry Creek breaks across this scarp in an abrupt canyon but in its upper course forms a broad, flat basin at altitudes of 5,000 to 5,500 feet. The ore deposits occur in this basin and also on the steep slope facing the Verde Valley. A discussion of the interesting physiography of the Black Hills is given on page 8 .

Most of the country is covered by chaparral, which is especially dense on the southward slopes south of the Cherry Creek basin. At 5,000 or 5,500 feet above the sea the chaparral gives way to pine forests, which cover the higher part of the ridge.

The country rock of the deposits is the normal Bradshaw granite, massive and forming large rounded outcrops of a yellowish-white tinge. This rock occupies a broad area about 10 miles wide, cutting through the Yavapai schist, which forms the greater part of the Black Hills. On the southeast the Yavapai schist appears again in Cherry Creek canyon. Toward the south and southeast the granite is covered by Tertiary volcanic flows, which slope southward and occupy much space in the northeast corner of the Bradshaw Mountains quadrangle.

Reid; who visited the district in 1905 , before the deeper levels had been opened but while the upper workings were accessible, states that the veins follow shattered or sheared dikes of granite porphyry extending in a northerly direction and dipping west at

${ }^{40}$ Reid, J. A., A sketch of the geology and ore deposits of the Cherry Creek district, Ariz. : Econ. Geology, vol. 1, pp. 417-436, 1906. 
moderate angles. A few dikes, he says, dip at low angles to the east or north. The largest dike is the most easterly one, at the Pfau mine.

Several flat-topped hills in the basin are capped by the Cambrian basal sandstone (Tapeats), thin, lying almost horizontal, and covered by Devonian limestone. The same Paleozoic beds also cap some, of the higher ridges to the north of the basin.

\section{QUARTZ VEINS}

The Cherry Creek quartz veins are worked mainly for gold. Some production is reported from the district, but the total is not large and is very difficult to estimate. In 1922 the Monarch mine was being worked on a small scale and the Logan mine was being reopened. There are five or six small gold mills in the district. Most of the work appears to have been done about 1907, though the Monarch mine has been worked since 1883 .

All the veins are similar in character and are contained in normal massive Bradshaw granite. They are shear zones, usually 2 to 4 feet wide, with bunches of quartz. They strike from north to N. $20^{\circ} \mathrm{E}$. and dip as steeply as $40^{\circ} \mathrm{W}$.

The quartz is massive and milky white, with a greasy luster, and in at least two of the properties, the Logan and Inspiration, contains little greenish-black streaks and bunches that look like chlorite but proved to contain small prisms of tourmaline. Probably this mineral will be found in all of the quartz. Free gold is common, usually in visible particles in the massive quartz, but some gold is derived from oxidized sulphides. The ore forms pockets or irregular small shoots.

Massive irregular sulphide grains are intergrown with the quartz; in places there are also cubes of limonite pseudomorphous after pyrite. Chalcopyrite, bornite, sphalerite, and galena were observed in small quantities. The concentrates after amalgamation are said to contain gold to the value of $\$ 80$ to $\$ 100$ to the ton, also some silver.

The workings are mainly tunnels and inclined shafts. None of the shafts are more than 350 feet deep on the incline. The operations seem to have come to a standstill when the wholly unoxidized ore was reached.

These veins are undoubtedly high-temperature deposits of the quartz-tourmaline type. They were formed during pre-Cambrian time, after the intrusion of the granite and long before erosion had planed down the surface on which the Cambrian Tapeats sandstone was laid down. Remnants of this sandstone are found in the 
Cherry Creek basin at about the same altitude as some of the veins. As no veins or any indications of mineralization are observed in this sandstone, the age as well as the physical conditions of vein formation are clearly proved in this district.

Reid states that the water level is found at about 60 feet below the surface, but that complete oxidation extends far below this level. $\mathrm{He}$ also comments on the absence of oxidized copper ores from the upper limonitic zone. This is in keeping with the fact that this oxidized zone was developed on the pre-Cambrian peneplain, long before the deposition of the Paleozoic beds. The leaching of copper has been complete in upper levels. In the oxidized zone, which appears to have reached to about 300 feet below the surface, scattered remains of sulphides are seen, with much limonite, abundant solution cavities, and in places many visible specks of native gold. Some of the solution cavities are filled with a secondary mixture of quartz, limonite, and probably also hematite, and on this dark-brown mass small quartz crystals have again been deposited, all during the progress of oxidation. Some of the veins close to Cherry Creek station contained much of this limonite, which was mined as a free-milling gold ore.

\section{HISTORY}

The district contains many properties that have made some production, and some of them were in operation at the time of visit. Many of them appear to have a certain resemblance in their history. There was the discovery, the arrastre stage, the sinking of a shaft to a depth of 200 or 300 feet, followed by the erection of a small mill, and next usually a prolonged rest, with a watchman in charge. The pockety character of the ore is the cause of this stoppage of exploration. Whether any large ore shoots will be frund is probably doubtful.

Many of the mines, the Monarch property in particular, were operated in a small way in the early days, their ore generally being reduced in arrastres. About 15 years ago mills were built on many properties. In the volumes of Mineral Resources published annually by the United States Geological Survey there are, since 1907, several notes on the district, compiled by V. C. Heikes in connection with statistics of production.

In 1907 seven properties were in operation, with six mills. Some high-grade ore containing as much as $\$ 60$ or even $\$ 100$ to the ton was extracted. In 1908 six mines yielded 464 tons, from which was obtained $\$ 5,775$ in gold and 86 ounces of silver, a total value of $\$ 12$ to the ton. In 1909 four mines produced 330 tons yielding 329 ounces of gold and 127 ounces of silver, together with 29 tons of concentrates yielding 40 ounces of gold and 115 ounces of silver. 
In 1910 seven mines produced 1,332 tons, from which was obtained $\$ 6,352$ in gold and 93 ounces of silver; this ore was obviously of low grade. In 1911 the district yielded $\$ 9,402$ from 531 tons of ore, or about $\$ 17$ to the ton. The producers were the Etta, Federal, Hillside, and Leghorn mines. In 1912 the Monarch and two other properties produced gold. In 1914 the production was $\$ 2,866$ from four properties. In 1915 ore was mined from the. St. Patrick, Garford, and Esmeralda claims. In 1916 two properties produced a little bullion, and a shipment of copper ore was made. Since then little work has been done. In 1922 operations were again begun at the Monarch and the Logan. The Arizona Copper-Gold Co. developed a copper prospect near Cherry. For information I am indebted to Mr. J. T. Sessions, an old-time resident of the district.

\section{MONARCH MINE}

The Monarch mine, also known as the Mocking Bird, lies at the foot of the eastern slope of the Black Hills, 12 miles south-southeast of Jerome, at an altitude of about 4,500 feet. It is owned by the Verde Mines Development Co., and is an old-time property, worked at intervals since 1886 . The place is reached by going down the main road in the Verde Valley about 12 miles south of Clarkdale and then turning up to the foot of the mountains, about $33 / 4$ miles distant. The mine has been operated at intervals and has yielded probably more than any other mine in the district. There are two mills, one with five stamps and the other with ten. Most of the old tunnels are caved.

The country rock is a sandy light-colored granite containing quartz, feldspar, and a little biotite and hornblende, with a few veinlets of epidote. There are several veins striking $\mathrm{N}$. $10^{\circ}-20^{\circ}$ E. and dipping $32^{\circ}-45^{\circ} \mathrm{W}$. The country rock close to the veins shows practically no alteration. The coarsely crystalline white quartz occurs in lenses several feet in maximum width, and carries bright-yellow native gold in wholly irregular pockets and small shoots. One such shoot was mined in 122 from a vein about 150 feet above the mill. The gold occurs mainly as particles in the solid quartz. The ore is said to average $\$ 20$ to the ton and yields some concentrates of galena and chalcopyrite. It is mostly free milling. The quartz shows solution cavities filled with hematite and limonite.

\section{MINES NEAR THE MONARCH}

From the Monarch mine the mineral belt extends southwestivard across the divide to the vicinity of Cherry Creek. There are several properties southwest of the Monarch, among which the best known are the Etta, the Gold Ring, and the Conger. Some production is 
reported from all these mines. The Etta is mentioned in the Mint report for 1887 as a quartz vein 5 to 6 feet wide, developed to a depth of 200 feet, and containing ore of a value of $\$ 29$ to the ton.

The road to Cherry Creek leads off a few miles farther south in the valley at Aultman. A line of sycamores indicates the position of Verde River, and the old Prescott road turns to the west over the uplands and flat mesas of the Verde formation of Tertiary lake beds, sparsely covered by mesquite. Within a short distance the road reaches heavy beds of Quaternary conglomerate, which continue up to a gap at an altitude of 5,400 feet, where the Verde fault brings up the granite of the main ridge of the Black Hills. A little to the south of the road Cherry Creek, on its way to Verde River, has incised a canyon 500 feet deep, the erosion having been accelerated by the great fault. At the gap is the Blue Monster property, the shaft of which, 400 feet deep, is sunk almost on the fault line, at first in gravel, then in lava, and finally apparently cutting into the granite. Why it was sunk is not clear, probably with a wild hope of striking a copper deposit. A mile to the north is the Pfau mine, which was being operated in 1904 on a quartz vein in granite and from which some production was obtained. Locally the Pfau mine is known as having been the scene of some interesting sampling operations a number of years ago. Two or three miles farther on the road leads into the pretty basin of upper Cherry Creek (altitude 5,000 feet), in which most of the properties of the district are situated.

\section{GOLDEN IDOL MINE}

The Golden Idol mine, owned by the Verde Inspiration Co., is the property formerly known as the Hillside, $1 \frac{1}{2}$ miles northnortheast of Cherry, at an altitude of 5,400 feet. There appear to be three veins on the property and on one of them an incline 375 feet long has been sunk at a dip of $35^{\circ} \mathrm{W}$. A stamp mill and a cyanide plant are on the property, which was worked from 1907 to 1910. Pits near the shaft show a 4-foot vein of sheared granite with bunches of quartz. The quartz shows bluish-black streaks of microscopic tourmaline, also a little pyrite and chalcopyrite. It contains solution cavities with limonite. The ore is said to have contained $\$ 7$ to $\$ 12$ to the ton.

CONGER AND INSPIRATION MINES

The Conger mine lies to the northeast of the Golden Idol, across the divide. These two may well be on the same vein system as the Monarch mine. The general strike would be N. $30^{\circ}$ E. and the dip to the west. 
The Federal mine, about a mile north of Cherry, at an altitude of 5,600 feet, is said to be owned by Mr. Wombacher, of Cherry. The vein dips south or southwest and is opened by 260 -foot incline. It was worked about 1907 . The country rock is red and white granite.

\section{LEGHORN MINE}

The Leghorn mine, now owned by the Arizona Copper-Gold Mines Co., is situated about 2 miles north of Cherry, at an altitude of 5,800 feet. The vein is contained in granite and has been opened by an incline 600 feet long, dipping $35^{\circ} \mathrm{W}$. In Weed's Mines Handbook for 1922 it is stated that there are 6,000 feet of workings. A Chilean mill has been erected on the property. The mine has had some production. The vein is said to average 2 feet in width. The quartz contains chalcopyrite and gold, but it is probable that difficulties were encountered below the zone of oxidation. Specimens from the dump show abundant solution cavities filled with hematite and secondary quartz. Above the Leghorn is the Ann C. mine, which has similar ore. A short distance north of Cherry a prospect was opened in 1922 by the same company at an altitude of about 5,250 feet, on a sheared vein 4 feet wide, striking north and dipping $45^{\circ} \mathrm{W}$. This vein contains good bunches of quartz with heavy copper stain, and the ore is said to assay well in copper, gold, and silver.

\section{LOGAN MINE}

The Logan mine is about 2 miles southwest of Cherry. The vein, like the others, is in granite and dips $50^{\circ} \mathrm{W}$. The shaft is 286 feet deep on the incline. Decomposed granite and much slightly copperstained quartz lie on the dump. It is claimed that 6,000 tons of ore are blocked out. There is a small mill on the property, and it was being reopened in 1922 by a company with the suggestive name of the New United Verde Copper Co., which also owns the Lucky dome property not far away.

\section{PRESCOTT DISTRICT}

GEOLOGY

The Prescott district includes the northern foothills of the Bradshaw Mountains between Prescott and Agua Fria River. Prescott lies in the basin of Granite Creek, in the area of massive Bradshaw granite that occupies the southwest corner of the Jerome quadrangle. The granite is adjoined on the east by the north end of a great mass 
of Yavapai schist, which, however, is tremendously injected by granite and pegmatite. The exposures on the road to Dewey, on Agua Fria River, are good, and there is in many places a question whether the granite or the schist predominates. Much of the granitic rock shows a rude schistosity. At the western contact of the schists the rock seems to be mainly a dense amphibolite. At the bridge across Lynx Creek the exposures show fissile schist with cherty beds injected by granite. In the granite are seen veins of quartz which are themselves cut by veinlets of epidote.

East of the schist the Bradshaw granite reappears, forming a belt about 2 miles wide, which is in turn adjoined by schist extending to Agua Fria River. Tertiary volcanic tuffs cover a few areas on the hills near Prescott. From their relation to the present drainage it is clear that the valley of Granite Creek has been eroded only to a depth of about 300 feet since the volcanic epoch.

To the north and east, toward Agua Fria River, bench gravel rests on the bare foothills and rises about 200 feet above the present streams. Along Lynx Creek above the bridge the small areas of bench gravel lie 30 to 40 feet above the stream channel.

\section{QUARTZ VEINS}

The only lode deposits observed in these foothills are quartz veins of undoubted pre-Cambrian age. On the divide between Granite and Lynx Creeks is the Bullwhacker prospect, on which some work has been done. Here a vein of massive quartz is several feet wide and trends N. $18^{\circ} \mathrm{E}$., probably with the schist. It is contained in a black, dense amphibolite, cut by dikes of a dioritic rock, probably a contact facies of the Bradshaw granite, which begins only a few hundred feet to the west. The massive milky-white quartz contains a little pyrite in crystals and stringers. The deposit has evidently been prospected for gold and has been opened by a shaft, now caved but probably 100 feet deep.

East of the Lynx Creek bridge there is a considerable area of dark diorite adjoined on the east by more schist, which continues as far as the eastern body of granite. In the granite just before the road descends into the open valley there are several prospects, evidently opened for gold on rather thick quartz veins both north and south of the road. These veins contain, besides quartz, some siderite, chlorite, and pyrite, also much black radial tourmaline.

PLACER DEPOSITS

Lynx Creek is noted as one of the most productive gold-bearing streams of the State. It heads in the Walker district (p. 109), in the northern part of the Bradshaw Mountains, and discharges 
its waters into Agua Fria River 2 miles north of Dewey. Gold is found in its gravel along its whole course, undoubtedly all set free from the gold quartz veins of the Walker district. It is a small stream lined with patches of bench gravel in the middle and lower parts of its course. Gravel spread out along the lower course is reported to contain enough gold for dredging.

The placers were discovered about 1863, it is said, and the richest parts were soon exhausted. In Raymond's report for 1874 the production of placer gold from Lynx Creek is given as only $\$ 10,000$.

In the eighties of the last century an Englishman, Barlow Massick, took out placer gold by hydraulic mining about 12 miles below Walker.

A steam shovel was in operation from 1892 to 1895 about 11/2 miles below the Lynx Creek bridge, on a gravel flat of 10 to 20 acres in the bottom of the creek. Below this locality the dredging ground is reported to be 400 feet wide and extends for 3 miles down the creek. The depth to bedrock is said to be about 15 feet, and the average value of the gravel is reported as 18 cents to the cubic yard. Difficulties of consolidation are said to have prevented extensive working by modern methods. At the present time small operators at several points below Walker take out a little placer gold, perhaps to the value of a couple of thousand dollars a year.

The total production from the gravel of Lynx Creek is estimated at $\$ 1,000,000$, most of which was extracted in the early days of the district.

At Walker the placers yielded nuggets worth as much as $\$ 80$, about $\$ 16$ an ounce. Lower Lynx Creek produced a finer-grained gold of higher value, worth about $\$ 18$ an ounce. Such an enrichment in the value of the gold is common and indicates a solution of the silver by the waters.

\section{WALKER DISTRICT}

The Walker district lies in the upper valley of Lynx Creek, 7 miles southeast of Prescott, at an altitude ranging from 6,200 to 7,000 feet. It is one of the oldest camps in the region, as the ore was found by the placer miners working up from the lower placers. In the early days ore from many of the outcrops of the oxidized veins was worked in arrastres. Any of the numerous vein croppings will show gold in the pan. Later, mainly before 1910, a considerable amount of deep mining was done on the Sheldon, Mudhole, Amulet, and other properties. In the mint report for 1887 it is stated that 161 tons of ore from the district averaged $\$ 10.65$ a ton. In Mineral Resources for 1908 it is stated that 142 tons was shipped containing 262 ounces of gold and 455 ounces of silver. Mills treated 450 tons, 
which yielded 726 ounces of gold and 446 ounces of silver, with pyritic concentrates of 69 tons containing 160 ounces of gold and 202 ounces of silver. In 1922 the Sheldon mine was reopened with gond results and some leasing was done on other properties. Preparations were made to reopen the tunnel to Poland, through which it was intended to ship the ore from the Sheldon mine to the Humboldt smelter.

The veins are mainly confined to a small stock of quartz diorite (granodiorite) 2 miles long and 1 mile wide, intruded in the Yavapai schist on the northwest and in the Bradshaw granite on the southeast. The diorite forms white rounded outcrops. The schist in the lower part of the district contains numerous strong dikes of rhyolite porphyry. One of these at the crossing of Lynx Creek about a mile below Walker is 200 feet wide. Some of them also occur in the granodiorite. The veins are fissure deposits with quartz and sulphides containing both gold and silver; there is more free gold in the oxidized material than in depth. The ores have been worked in mills, but the unoxidized ore is now generally shipped to smelters. The dip is steep, and the width reaches several feet; within this thickness there are usually several streaks of quartz rich in sulphides.

The total production of the district from the lode mines is probably not more than $\$ 1,500,000$. No exact figures are available.

Copper, lead, zinc, gold, and silver produced in Walker district, 1905-1924

[Compiled by V. C. Heikes, U. S. Geological Survey]

\begin{tabular}{|c|c|c|c|c|c|c|}
\hline Year & $\begin{array}{c}\text { Crude ore } \\
\text { (tons) }\end{array}$ & $\begin{array}{l}\text { Copper } \\
\text { (pounds) }\end{array}$ & $\begin{array}{c}\text { Lead } \\
\text { (pounds) }\end{array}$ & $\begin{array}{c}\text { Gold (fine } \\
\text { ounces) }\end{array}$ & $\begin{array}{c}\text { Silver (fine } \\
\text { ounces) }\end{array}$ & Total value \\
\hline 1905 & $\begin{array}{r}4,000 \\
158 \\
321 \\
592 \\
280 \\
9,295 \\
\times 2,634 \\
361 \\
a 596 \\
310 \\
899 \\
323 \\
132 \\
89 \\
175 \\
13 \\
148 \\
139 \\
9.155 \\
6,075\end{array}$ & $\begin{array}{r}96,000 \\
2,430 \\
-3,860 \\
8,325 \\
3,745 \\
5,235 \\
7,270 \\
1,784 \\
16,440 \\
1,916 \\
6,331 \\
3,181 \\
254 \\
269 \\
87 \\
2,757 \\
438,298 \\
133,463\end{array}$ & \begin{tabular}{r}
5,860 \\
14,485 \\
94,477 \\
23,589 \\
963 \\
27,202 \\
6,615 \\
7,378 \\
5,381 \\
4,165 \\
5,356 \\
7,778 \\
\hdashline 2,003 \\
\hdashline 13,520 \\
80,791
\end{tabular} & $\begin{array}{r}989.00 \\
40.92 \\
201.77 \\
1,395.24 \\
404.70 \\
2,916.11 \\
1,547.91 \\
441.76 \\
593.14 \\
323.44 \\
750.75 \\
242.80 \\
205.07 \\
192.04 \\
90.52 \\
35.12 \\
98.00 \\
109.45 \\
2,447.61 \\
989.57\end{array}$ & $\begin{array}{r}12,006 \\
2,442 \\
994 \\
1,139 \\
629 \\
7,840 \\
3,282 \\
1,680 \\
4,056 \\
1,879 \\
4,635 \\
990 \\
1,697 \\
1,440 \\
249 \\
158 \\
1,867 \\
625 \\
77,165 \\
22,873\end{array}$ & $\begin{array}{r}\$ 42,672 \\
2,507 \\
5,312 \\
29,691 \\
9,818 \\
69,730 \\
34,911 \\
11,072 \\
19,115 \\
8,219 \\
21,093 \\
6,512 \\
7,723 \\
6,575 \\
2,609 \\
947 \\
3,994 \\
3,, 260 \\
174,249 \\
\ldots . . . . .\end{array}$ \\
\hline
\end{tabular}

a Includes recovered zinc: $1911,35,269$ pounds; $1913,37,146$ pounds.

\section{SHELDON MINE}

The Sheldon property of 11 patented claims is situated in granodiorite in the southwestern part of the district near the gulch, at an altitude of 6,500 feet. The deposit is a normal fissure vein with 
a strike of $\mathrm{N} .30^{\circ} \mathrm{E}$; t the dip is $81^{\circ} \mathrm{SE}$. near the surface, but soon flattens to $70^{\circ}$. The developments consist of a vertical shaft 650 feet deep with drifts extending for several hundred feet on the 250, 450 , and 650 foot levels. The old shaft is 500 feet southwest of the present working shaft. The old stopes, from which more or less oxidized ore has been mined, are above the 200 -foot level and extend in places to the surface.

The total production of the mine up to 1922 is estimated at about $\$ 200,000$, but there are no definite data. In 1923 the mine had a large production. Most of the work above the 200-foot level was done prior to 1898 ; in that year the mine was worked by W. I. Casey. For 20 years lessees had been at work on the property. At the present time it is opened by the Sheldon Mining Co. under the direction of A. R. Ackerman. The shaft makes about 45,000 gallons of water in 24 hours.

The minerals consist of quartz and some calcite, with more or less pyrite, sphalerite, chalcopyrite, galena, and tetrahedrite. The quartz is milky white and contains vugs with small projecting crystals. In the upper levels there is some chalcocite coating the chalcopyrite.

The gold and silver seem to be associated with the galena and tetrahedrite; the chalcopyrite also carries gold. Not more than 30 per cent of the gold and silver in the primary ore can be amalgamated. The sericitic and pyritic granite contains only $\$ 2$ or $\$ 3$ to the ton, but the quartzose ore in the shoots yields perhaps $\$ 20$ to $\$ 30$. Most of the value of the ore is in gold. Usually it contains but a few ounces of silver to the ton. According to a report by C. $\mathrm{H}$. Dunning the ore now mined is said to average about 2.76 per cent of copper, 3.5 per cent of lead, and $\$ 5$ in gold and 8.5 ounces of silver to the ton. The best ore developed seemed to be on the 450 -foot level north of the crosscut, where the vein in one place widens to 16 feet, though the average is 4 to 5 feet. The stope length is said to be 700 feet. The same shoot is shown in the north drift on the 650 -foot level. Here there is 5 feet of sericitic granodiorite with a few inches of high-grade quartz streaks along the sharply defined hanging wall and footwall. In places the vein closes down to a seam. The shoot appears to pitch north parallel to the striations on the walls, which $\operatorname{dip} 60^{\circ}$ in that direction.

The Sheldon vein can be traced for at least half a mile to the southwest and several hundred feet to the northeast. A crosscut is now driven on the 650-foot level in the hanging wall to a parallel vein named the "Capitol." 
The Mudhole mine lies on the south side of the creek between Walker post office and the Sheldon mine. It is a well-known property, which is reported to have yielded $\$ 480,000$ in gold and silver, chiefly from 1897 to 1903 , although before that time more or less ore was extracted by lessees. In 1900 a mill was built for amalgamation and concentration. It is now reported to be controlled by W. I. Casey and C. T. Joslin, of Prescott. The property was idle in 1922, and, in fact, no work has been done on it sinee 1912. Ore and concentrates were shipped to Humboldt, El Paso, and Needles.

Jaggar and Palache state that at this mine there are two parallel veins, each 6 to 8 feet wide, in gneissoid granite. They also state that between the veins is a white dike of rhyolite porphyry. In part, however, the veins are certainly in a dark dense amphibolitic hornfels with much magnetite, striking N. $60^{\circ}$ E., and belonging to the Yavapai schist.

The main north shaft is near. Walker post office and is 740 feet deep on the incline of $47^{\circ}$. Apparently most of the workings were in hornfels. The south shaft and tunnel are about 2,000 feet from the main shaft. It is difficult to obtain reliable information as to the conditions on the lowest levels; probably the veins narrowed down in harder rock. The dumps at the tunnel show seams rich in galena and sphalerite with some chalcopyrite and pyrite in bleached hornfels.

The ore is said to have contained from $\$ 7$ to $\$ 15$ to the ton in gold and silver, mostly in gold. Shipping ore would contain $\$ 50$ to the ton. The concentrates were rich, averaging $\$ 70$ in gold, 5 ounces of silver, and $\$ 6$ in lead to the ton. Other statements credit these concentrates with an average of $\$ 125$ to the ton.

AMULET MINE

On the ridge on the Chaparral Creek side, 1 mile northeast of Walker post office, is the Amulet mine, near the contact of the Bradshaw granite and the Yavapai schist. Jaggar and Palache state that rich silver ore was obtained from a contact breccia between the two formations. Work was done on the Amulet in 1887 to 1891. High-grade ore shipped is said to have contained 459 ounces in silver and 46 per cent lead.

According to W. I. Casey the Amulet is the extension of the Mudhole veins. The shaft was sunk in recent years to a depth of 200 feet, but little further exploratory work was done. The dump shows mainly quartzite schist with disseminated pyrite and chalcopyrite. 


\section{OTHER PROPERTIES NEAR WALKER}

The granodiorite contains very many veins, most of them with northeast strike; those west of the Sheldon are said to dip west. Many of them have been worked on a small scale. Among them are the Victory vein, N. $30^{\circ} \mathrm{W}$. from the north Mudhole shaft, across the valley toward Groom Creek; the Pine Mountain vein, in the same direction, on which there is a vertical shaft 500 feet deep and which is said to have a shoot of ore 300 feet long; the Black Diamond, 1 mile north of the same point; and the Mark Twain, also 1 mile a little east of north.

\section{PROPERTIES NORTH OF WALKER}

Near the wagon road from Prescott to Walker, a few miles from Walker, are several small mining properties. Among them are the Big Dome and the Dinty on the south side of the wagon road, the former said to show a narrow vein of rich silver ore. In the schist there are many pre-Cambrian lenses of quartz but none of much value.

To the east of Lynx Creek is the Jenkins vein, $21 / 2$ miles northeast of Walker, in amphibolite and diorite; it shows pyrite and chalcopyrite scattered in a quartz lens of pre-Cambrian age. About $11 / 2$ miles northeast of this property is the Arizona Daisy, reported to contain silver and copper. Three miles northeast of the Jenkins mine is the Banner mine, which is said to have a shaft 325 feet deep with drifts on four levels; the deposit is a quartz vein with gold and silver.

\section{GROOIM CREEK DISTRICT}

The Groom Creek district, which is only a few miles south of Prescott, has been worked for many years but has not yielded a large output. The prospects lie mainly on upper Groom Creek in the Yavapai schist adjoining a stock of quartz diorite (granodiorite). The schists are mainly quartz-sericite schists of sedimentary origin. The quartz veins carry both gold and silver but are narrow and appear to have been worked with profit mainly in the upper oxidized zone. The most prominent properties are the Empire, King-KellyMonte Cristo, Victor, Home Run, and Midnight Test. None of them were actively worked in 1922. The Victor was worked in 1902-3, the Empire about 1902-1907, the Midnight Test about 1919, the Climax about 1905-1907 and 1914-1920. The Monte Cristo is reported to have made a considerable production in 1920 .

The King-Kelly fissure strikes N. $15^{\circ} \mathrm{W}$; ; it is a narrow vein containing fine-grained drusy quartz and sparsely disseminated pyrite and a little galena, with vertical or steep westerly dip. The 
adjoining schist contains a notable amount of nearly colorless tourmaline.

The Empire vein, close by, strikes N. $20^{\circ}$ W. It is developed by a shaft sunk to water level, at a depth of 300 feet. A considerable amount of ore from the oxidized zone has been milled; the ore becomes pyritic in depth. At the surface the vein crops out in quartzitic schist and diorite. It has not been worked since 1910. A 10stamp mill with plates and concentrators is on the property. The ore contains about equal values of gold and silver.

The Midnight Test vein, which near the surface carried a small shoot of rich silver ore, is situated high up near the Groom CreekWalker divide. It is a 2 -foot vein in schist and has been opened to the 400 -foot level. The production is reported to be $\$ 100,000$.

\section{HASSA YAIMPA DISTRICT}

In the highest and wildest part of the Bradshaw Mountains lies the Hassayampa district. It is a region of heavily forested ridges and long slopes covered with dense brush. The deeply incised canyons of the headwaters of Hassayampa River and its tributaries, Slate Creek and Crooks Canyon, drain it to the southwest. From the spruce-clad heights of Mount Union and Mount Tritle, nearly 8,000 feet above sea level, the district reaches down to the river of the wonderful water, ${ }^{47} 3,500$ feet lower. From the summits the view extends far westward across the desert valleys to the great blue dome of Harquahala Mountain, in the far distance. The district occupies the northwest corner of the Bradshaw Mountains quadrangle and borders on the northeast the Groom Creek and Walker districts. On the southeast it is adjoined by the Turkey Creek district.

The area includes many mines of considerable production, mostly in silver and gold.

The Bradshaw granite of Mount Union forms a broad dikelike mass extending northeastward between two areas of Yavapai schist. In the extreme northwest corner of the Bradshaw Mountains quadrangle the same pre-Cambrian granite appears again and continues northward to Prescott. The belt of Yavapai schist between these two granite areas contains most of the mines, though some are also found in the easterly granite area south of Mount Union.

The Yavapai includes sericitic, chloritic, and amphibolitic schists, but the amphibolitic type predominates. The schists are intruded by several smaller masses of diorite or gabbro and also, in the Groom Creek basin, by a larger mass of granodiorite (quartz diorite, according to Jaggar and Palache). The strike of the schists is northnortheast, the dip steep. Granite and schist are intruded by a series

47 "He who drinks of the waters of the Hassayampa will never leave Arizona and will never again be able to tell the truth."-Old saying. 
of light-colored dikes of rhyolite porphyry, which stand in closest relation to the ore deposits. The strike of these dikes ranges from north to northeast. Few of them are wider than 100 feet.

The ore deposits are almost exclusively fissure veins and carry gold and silver, generally both, though some yield only gold and some only silver.

The pre-Cambrian gold veins are represented by the Ruth and Jersey Lily mines and by several deposits in the lower part of Crooks Canyon. Probably the Blue Dick, Mark Twain, Buzzard, and Dunkirk belong to the same category. Another group of mines, some of which have had a large production, center about the northern slopes of Mount Tritle and Mount Union. They are on gold-silver veins that are closely connected with the rhyolite porphyry dikes, and the Senator is the best known among them. These veins are much younger than the pre-Cambrian deposits and probably are of Tertiary age. Similar to these are the long veins on the south slopes of Mount Union, extending down to Venezia. Some of these deposits indicate a formation at higher temperature; others recall the features of veins formed near the surface and carry mostly rich silver minerals.

During the last 10 years there have been from 10 to 15 producing properties each year. Placer deposits have been worked along Hassayampa River.

Gold, silver, copper, lead, and zinc produced in the Hassayampa and Groom Creek districts, 1904-1924

[Compiled by V. C. Helkes, U. S. Geological Survey]

\begin{tabular}{|c|c|c|c|c|c|c|c|}
\hline Year & $\begin{array}{l}\text { Ore } \\
\text { treated or } \\
\text { shipped } \\
\text { (tons) }\end{array}$ & Gold & $\begin{array}{l}\text { Silver } \\
\text { (fine } \\
\text { ounces) }\end{array}$ & $\begin{array}{c}\text { Copper } \\
\text { (pounds) }\end{array}$ & $\begin{array}{c}\text { Lead } \\
\text { (pounds) }\end{array}$ & $\begin{array}{c}\text { Zinc } \\
\text { (pounds) }\end{array}$ & $\begin{array}{l}\text { Total } \\
\text { value }\end{array}$ \\
\hline $\begin{array}{l}1904 \\
1905 \\
1906 \\
1907 \\
1908 \\
1909 \\
1910 \\
1911 \\
1912 \\
1913 \\
1914 \\
1915 \\
1916 \\
1917 \\
1918 \\
1919 \\
1920 \\
1921 \\
1922 \\
1923 \\
1924\end{array}$ & $\begin{array}{r}7,490 \\
5,122 \\
3,586 \\
4,508 \\
470 \\
3,510 \\
1,341 \\
1,871 \\
2,570 \\
1,646 \\
1,371 \\
2,209 \\
1,969 \\
2,294 \\
2,916 \\
359 \\
1,170 \\
158 \\
50 \\
74 \\
156\end{array}$ & $\begin{array}{r}\$ 101,135 \\
36,486 \\
21,910 \\
25,363 \\
6,534 \\
7,050 \\
8,718 \\
19,583 \\
22,016 \\
13,433 \\
16,483 \\
20,612 \\
12,369 \\
10,094 \\
15,072 \\
3,025 \\
5,151 \\
2,717 \\
678 \\
1,165 \\
2,937\end{array}$ & $\begin{array}{r}20,436 \\
14,818 \\
3,435 \\
16,890 \\
595 \\
2,092 \\
1,593 \\
3,143 \\
14,916 \\
18,352 \\
15,337 \\
26,294 \\
53,227 \\
13,873 \\
17,196 \\
5,589 \\
12,112 \\
1,095 \\
1,989 \\
1,544 \\
1,017\end{array}$ & \begin{tabular}{r}
60,269 \\
10,000 \\
254,934 \\
4,453 \\
585 \\
392 \\
1,330 \\
68,519 \\
80,173 \\
36,717 \\
100,314 \\
76,662 \\
12,786 \\
10,494 \\
1,412 \\
11,915 \\
\hdashline 114 \\
461 \\
572
\end{tabular} & $\begin{array}{r}358,525 \\
262,760 \\
21,053 \\
58,775 \\
787 \\
33,208 \\
14,723 \\
45,609 \\
157,706 \\
102,573 \\
69,938 \\
49,827 \\
51,112 \\
163,780 \\
126,964 \\
6,117 \\
14,474 \\
2,909 \\
4,174\end{array}$ & 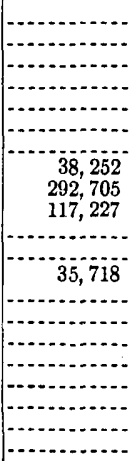 & $\begin{array}{r}\$ 128,405 \\
67,188 \\
27,376 \\
90,612 \\
7,470 \\
9,642 \\
10,276 \\
25,646 \\
69,789 \\
48,023 \\
32,575 \\
53,840 \\
74,564 \\
39,101 \\
43,875 \\
9,872 \\
21,703 \\
3,943 \\
2,682 \\
2,499 \\
4,027\end{array}$ \\
\hline
\end{tabular}

BIG PINE MINE

The Big Pine mine, 6 miles south of Prescott, on the Hassayampa, visible from Groom Creek, has four tunnels between altitudes of 7,000 and 7,400 feet and a 200-foot shaft with drifts 200 and 350 
feet long. There is a cyanide plant on the property, which apparently has had little production. Mr. C. H. Dunning states that the vein occupies a fracture in quartz diorite and contains quartz and pyrite. The oxidation is said to be deep, and the ore shoots long and irregular. The vein strikes $\mathrm{N}$. $35^{\circ} \mathrm{W}$. and dips $70^{\circ} \mathrm{NW}$. The ore is reported to contain $\$ 9$ to the ton in gold and silver, about half of each by value. About half a mile above the Delta camp on the Hassayampa, according to Mr. Dunning, is the Howard or Harlan property, at which in 1900 three pockets of gold were extracted to the value of $\$ 40,000$. The deposit is said to be a fissure in diorite.

On the lower Hassayampa 1 mile below the bridge at the west margin of the Bradshaw Mountains quadrangle is the mine of the United Gold \& Silver Mining Co. It appears to be a quartz vein of pre-Cambrian type, and Mr. Tomlinson states that in former years he has extracted gold ore to the value of $\$ 100,000$ from it.

\section{RUTH MINE}

The Ruth mine, the property of the Arizona-California Mining Co., has been worked for gold on a quartz vein three-quarters of a mile north of Hassayampa River on the Jersey Lily road. The developments consist of a shaft 300 feet deep and a gold mill. There was some production in 1911, 1912, 1913, and 1916. The concentrate is reported to contain 30 per cent of zinc, 55 per cent of lead, and 30 ounces of silver to the ton.

The vein, which dips steeply to the east, is contained i 1 the Bradshaw granite. The rock is schistose close to the walls, which are soft; probably sericitized, and impregnated with narrow seams of tourmaline and small crystals of pyrite. The quartz is milky and coarse grained. There is some banding by reopening near the walls, and along these planes are streaks of pyrite, ankerite, and tourmaline.

The ore shows much tourmaline in small black needles contained in the quartz, and tourmaline is also inclosed in the massive sulphides. The sulphides, which occur in irregular bunches, comprise pyrite and chalcopyrite, with some galena and sphalerite. Small seams of chalcopyrite in places cut across the quartz. The tourmaline is mainly deposited along the walls.

From the Ruth mine the road crosses Hassayampa River, where there is plenty of evidence of old placer work on a small scale. The Bradshaw granite is here darker than usual and cut by dikes of whiter granite. About 300 feet above the river to the south some schist appears, and beyond it is a considerable area of coarse, dark pyroxenite or gabbro. Beyond this area the Yavapai schist predominates, intruded in places by dikes of light-colored rhyolite por- 
phyry, particularly above the N. C. 4 mine. The road follows the 6,300 -foot contour for some distance and affords a wide view to the west over the brushy Hassayampa slopes. The rocks consist of the Yavapai schist, in part chloritic, in part distinctly like clay slate.

\section{N. C. 4 MINE}

About 300 feet below the road in a deep gulch is the N. C. 4 mine, almost exactly on the western boundary of the Bradshaw Mountains quadrangle. The N. C. 4 mine is credited with a notable production of very rich silver ore. The developments consist of a tunnel and a shaft 300 feet deep, both on a nearly vertical vein that appears to follow the country rock, a fissile clay slate, in part silicified. There was no one at the mine when it was visited, but the shaft had recently been in operation. Several typical dikes of rhyolite porphyry are exposed along the road that leads down to the mine.

The ore of this narrow fissure vein carries barite, in part crystallized, some quartz of fine-grained appearance, and some calcite. The ore minerals are tetrahedrite and azurite, with some galena and a little pyrite.

\section{JERSEY LILY MINE}

The road continues southward to the Jersey Lily mine, which is on a ridge at an altitude of 6,000 feet, overlooking the Hassayampa drainage basin. It is about 3 miles due south from the N. C. 4 mine. The rocks first encountered along the road are amphibolite schists, but near the mine there are slaty and fissile rocks with north strike and steep dip. In the shaft, however, the schist has a decidedly amphibolitic appearance.

The deposit is a thick pre-Cambrian gold quartz vein of low grade which contains scattered rich spots. The production is said to amount to $\$ 7,000$. The quartz is milky white and massive, with a few small crystals and irregular, stringlike veinlets of pyrite. It also shows some stains of chromium mica. The vein apparently conforms in strike and dip with the slates. No work was done on the property in 1922. It is said to be owned by Hill \& Burmister, of Prescott.

\section{BLUE DICK AND MARK TWAIN MINES}

The Blue Dick and Mark Twain veins are on a narrow ridge, at an altitude of 6,500 feet, that separates the Slate Creek drainage from that of the main Hassayampa. They are about 2 miles west of Mount Tritle, and the dumps of the Dos Oris are visible across the canyon to the east. The Blue Dick, now. owned by Judge Bushnell, of Cleveland, Ohio, is a silver mine of old reputation and has 
scattered over many years a considerable production to its creditperhaps $\$ 200,000$. Most of the ore came from the upper levels and was shipped to a smelter. Many years ago an attempt was made to smelt the ore in a local plant, and some loads of limestone used as flux still testify to this futile attempt.

The Blue Dick is developed by a tunnel about 200 feet below the crest of the ridge, on the east side. No work was being done in 1922 , and little could be seen in the old workings as far as accessible.

The country rock is a dense dull greenstone, in places schistose, evidently an amphibolite of the Yavapai schist. The deposit appears to be a fissure vein striking north and dipping east. The Mark Twain is a parallel vein not far distant on the west side. It is stated that these veins can be traced for a mile north of the present workings. The Mark Twain vein is developed by tunnels on the west side of the ridge. The ore, as can be seen from the dumps, consists of heavy sulphides in a gangue of massive quartz, not drusy, and showing strong effects of pressure, also some ankerite. The sulphides consist of pyrite and arsenopyrite, with smaller amounts of sphalerite, galena, and chalcopyrite, in places also tetrahedrite. The sulphide aggregates are coarse.

Most of the ore apparently came from the oxidized shallow zone, and the surmise would be reasonable that the ore had proved disappointing in such explorations as had been made below the tunnel level. The vein is probably of pre-Cambrian age.

\section{BUZZARD MINE}

Half a mile south of the Mark Twain and probably in continuation of that deposit is the Buzzard mine. Here there is a small shaft 135 feet deep, not now worked. The ore is of the same kind as in the Mark Twain and shows extremely crushed quartz with abundant small crystals of arsenopyrite and later cubes of pyrite. Associated with the quartz is some coarse ankerite. Mr. Tomlinson informed me that ore worth about $\$ 25,000$ has been extracted from the mine and presented me with a specimen of the rich ore. This proved to be freibergite, rich in silver, which replaces arsenopyrite, pyrite, and sphalerite.

\section{DOS ORIS MINE}

The Dos Oris (probably intended for Dos Horas) is a small but rich deposit half a mile east of the Blue Dick, at an altitude of 6,300 feet, on the headwaters of Slate Creek. It is mentioned in the Mint report for 1883 as a vein 5 feet wide yielding "chloride, black sulphurets, native silver, and streaks of galena." The ore was rich, much of it containing $\$ 1,000$ or $\$ 1,500$ to the ton, mainly in silver. The mine was then in operation, and it is said that there 
was a shaft 420 feet deep. In later years work has been done here at different times, but apparently no continuation of the deposit was found in depth. Mr. Tomlinson states that the total production was about $\$ 440,000$, though other statements credit the mine with a production of only $\$ 216,000$. The rich silver ore came from a stope near the surface. The lowest tunnel is said to be barren. Only a few dumps indicate the old position of this bonanza. The country rock is a greenstone schist.

\section{DAVIS MINE}

The Davis property is about half a mile east of the Dos Oris and at a somewhat higher altitude. The production is said to have been about $\$ 200,000$. The Davis mine is first mentioned in Raymond's report for 1874 . It is stated there that 35 tons of ore when shipped from this mine to San Francisco brought $\$ 16,455$ for the silver contained. The Davis is working on a wide vein with several streaks of ruby silver ore. It is now owned by Mr. Caspari, a well-known mining man of Prescott.

The ore consists of fine-grained quartz with many small druses and included greenish fragments of sericitic country rock. The ore minerals are sparse pyrite and yellow sphalerite in small aggregates. There are many grains of arsenical ruby silver (proustite) and a black mineral identified as polybasite. The silver minerals appear to be primary. The vein is distinctly of the shallow type usually associated with volcanic rocks.

\section{DUNKIRK MINE}

The Dunkirk mine is in the same gulch as the Davis, at the end of the wagon road from Mount Union pass, at an altitude of about 7,200 feet. The country rock is diorite. The vein strikes N. $60^{\circ}$ E. and is said to be continuous for a mile to the west of the tunnel. The ore consists of quartz with much pyrite and chalcopyrite, and it carries some gold and silver. It is the property of the Murphy estate.

'JILLLE STARBUCK MINE

The Tillie Starbuck mine is on the south slope of Mount Tritle, at the headwaters of Slate Creek of the Hassayampa drainage system, at an altitude of about 7,000 feet.

The country rock is Yavapai schist intruded by dikes of lightcolored rhyolite porphyry. The footwall is said to be followed by a dike of light-colored rhyolite porphyry 10 feet wide, in which few quartz grains are visible. The strike of the vein is $\mathrm{N} .10^{\circ} \mathrm{W}$., the 68508-26-9 
$\operatorname{dip} 80^{\circ} \mathrm{E}$; the width 2 to 17 feet. The outcrop is persistent on the high ridge to the south, where the ore is largely oxidized. There are three ore shoots with backs of about 700 feet above the lowest tunnel level. This lowest tunnel is first a crosscut southeast to the vein for 640 feet and continues on the vein for 1,000 feet. It is claimed that 100,000 tons of $\$ 10$ ore has been developed in the vein.

The ore, which is mainly quartzose, contains from $\$ 10$ to $\$ 17$ to the ton, of which two-fifths is gold and three-fifths silver. The ore carries free gold and pans colors. The quartz is rather fine grained, is milky with many small druses, and includes numerous sericitized rock fragments. Larger cavities are coated with a later dolomitic or ankeritic carbonate in small rhombohedrons. The ore minerals are sparse pyrite and sphalerite in small grains and in places specks of pyrargyrite, which appears to be of hypogene origin.

\section{SENATOR MINE}

The old and well-known Senator mine, situated on the headwaters of the Hassayampa, has been the property of the Phelps Dodge interests since 1889. It was worked from 1883 to 1899 . It is principally a gold property consisting of several parallel veins striking northnortheast. Among them are the Senator vein, carrying lead-zinc ores only and containing mostly gold with some silver; the Ten Spot vein, which carries mainly pyrite; the Tredwell vein, carrying heavy pyrite with specularite and gold; and the Snoozer vein, carrying copper ores with specularite. The shipping ore yielded $\$ 30$ in gold and silver to the ton. There is a small mill on the property in which the ore from the Senator shoot was worked. The total production is said to be about $\$ 530,000$ net, almost all of which came from the Senator ore shoot. Of this about $\$ 330,000$ was extracted since 1890 .

Most of the veins crop out near the loop in the wagon road, which here ascends the Mount Union pass, at an altitude of about 7,000 feet. The Senator veins cut across the road a short distance below the Mount Union pass (altitude 7,188 feet) and also crop out on the ridge a short distance to the west. Here the main shaft was sunk 635 feet deep to the tunnel level (altitude about 6,500 feet). Below this tunnel, which extends eastward to the Cash mine, the shaft is continued for 200 feet, giving a total depth of 835 feet.

The geology is complicated. There are lenses of diorite, amphibolite, and Yavapai conglomeratic schist, all traversed by dikes of rhyolite porphyry. One dike of this kind, about 40 feet wide, cuts the Yavapai schist along the road a short distance below the Mount Union pass. A vein striking N. $40^{\circ}$ E. from which a shipment was recently made crosses near the same place. It is probably the Ten 
Spot vein. The ore here, as exposed in a tunnel of quartzose ore, carries pyrite, chalcopyrite, and specularite.

According to information kindly given by Mr. J. S. Douglas, who operated the mine between 1891 and 1893 and from 1896 to 1899 , there was only one profitable ore shoot in the Senator properties, that of the Senator vein. This shoot starts just to the west of the old Senator shaft on top of the hill and pitches southward until on the tunnel level, 600 feet below the collar of the shaft, the center of the shoot is 450 feet south of the shaft. The shoot had a stope length of 250 feet and averaged 18 inches in width. The Senator shoot carried milling ore with free gold associated with quartz, pyrite, galena, and zinc blende. Magnetite occurred in the vein only north of the shoot, where it crosses Maple Gulch.

The Ten Spot, Snoozer, and Tredwell veins contained low-grade shipping ore with magnetite, specularite, chalcopyrite, and gold, but in the Senator property none of this material was extracted at a profit.

\section{CASH MINE}

About a quarter of a mile to the east of the wagon road on the north side of the Mount Union pass is the Cash vein. It lies about 1,000 feet east of the outcrops of the Senator group and is probably the extension of one of the Senator veins. In the Mint report for 1883 it is mentioned as being developed by three shallow shafts and having a 9 -foot vein with low-grade ore. Since that time it has been extensively developed, particularly from 1900 to 1902, but was idle from 1912 to 1922 , when it was again opened. It is reported to be the property of the Betty O'Neal Mining Co., of Nevada. The mine is developed by a shaft 400 feet deep and has a 10-stamp mill with plates and concentration. The value of the total production could not be ascertained.

Amphibolite schist crops out on the road between the Senator veins and the Cash. The shaft dump shows Yavapai schist injected with diorite. Dikes of normal rhyolite porphyry about 10 feet wide crop out along the road to the mine. The vein strikes N. $40^{\circ} \mathrm{E}$. and dips $60^{\circ} \mathrm{SE}$.

Jaggar and Palache ${ }^{48}$ describe the vein, which was being worked in 1900, as follows:

The ore body in this mine is in the form of a series of well-defined lenses that have a maximum thickness of $2 \frac{1}{2}$ feet and occur in sericite schist which is in places black and graphitic. The ore is rich in sulphides, chiefly galena, sphalerite, pyrite, and chalcopyrite, contains some tetrahedrite in quartz, and is characterized by comb and banded structure, the center of the vein being generally open and lined with beautiful crystals of all the vein minerals. A

\& U. S. Geol. Survey Geol. Atlas, Bradshaw Mountains follo (No. 126), 1905. 
rich body of free gold ore was found in this mine at a depth of 200 feet from the surface.

The ore seen on the dumps in 1922 contains predominating quartz with some calcite and more or less pyrite, sphalerite, and chalcopyrite. Some of the sphalerite is coated with covellite. On the main ore dump was noted banded ore of magnetite and pyrite like that in parts of the Senator mine.

Although the underground workings could not be visited, it seems clear that there are here two different kinds of veins, one of which contains magnetite, specularite, and adularia, in addition to pyrite, chalcopyrite, sphalerite, and galena, the place of the iron oxides in the succession being between pyrite and chalcopyrite. Figure 7

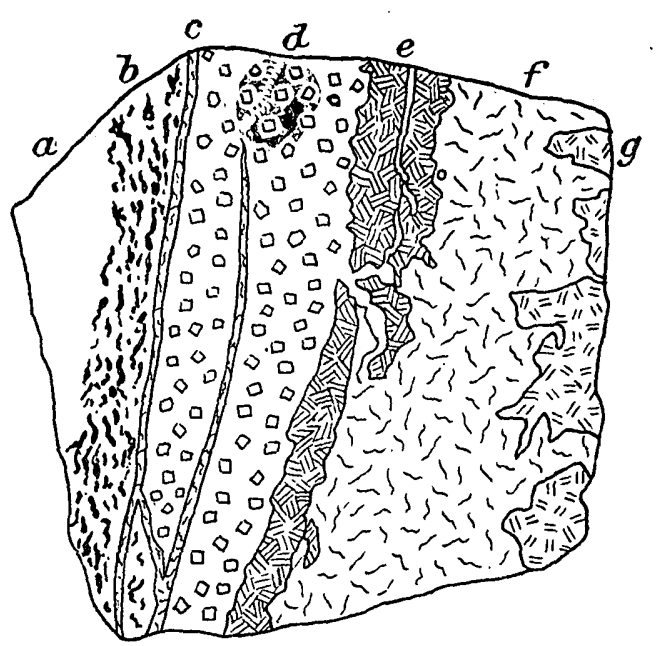

Figura 7.-Section of ore from Cash mine. $a$, Altered schist; $b$, magnetite with quartz and calcite; $o$, quartz veinlet; $d$, pyrite crystals disseminated, with quartz and calcite; $e$, massire pyrite; $f$, quartz with plates of specularite and some magnetite; $g$, chalcopyrite. Enlarged 2 diameters

shows in twice the natural scale the relation between the ore minerals. It appears that the deposition began with magnetite, quartz, and calcite, after which pyrite with quartz and calcite was deposited in small crystals and crystal aggregates. Then followed specularite in long laths in quartz; parts of the laths and masses of specularite consist of magnetite, suggesting that all of the specularite had passed through an earlier magnetite stage. Chalcopyrite is distinctly the last mineral. (See pl. 14, A.) Ore of a second type carries apparently only chalcopyrite, galena, and sphalerite.

\section{STORM CLOUD MINE}

The Storm Cloud mine is east of the Cash, in a gulch on the northwestern slope of Mount Union, at an altitude of about 7,200 feet. The main tunnel with the ore bodies is about three-quarters of 
a mile from the main road above the Cash mine. The shaft is 200 feet above the tunnel. The property appears to belong to the Betty O'Neal Mining Co., which also controls the Cash mine. The deposit could not be examined-in fact, it has not been worked since 1910 . A considerable amount of gold-silver shipping ore (profitable limit, $\$ 30$ a ton) has been produced, and it is said there is also a vein containing free-milling gold. This ore was freighted to Walker and thence to the Humboldt smelter.

The country rock is amphibolitic schist, though the granite contact should be close by toward the east. The ore contains pyrite, specularite, chalcopyrite, galena, and sphalerite in a quartz ganque.

\section{MINES NEAR CHICAGO MILI}

Above the Senator mill, on the old road that led over to Walker, are several prospects that have not been worked for many years. Among them are the Pickerell mine, which had a shaft 800 feet deep, and a 200-foot shaft near the site of the Chicago mill. No definite information concerning these properties could be obtained.

\section{STARLIGHT GROUP}

In the vicinity of Venezia, in Crooks Canyon, are a number of veins, including the Venezia, Crook, Starlight, and Mount Union, some of which are well-known producers, though idle at the present time.

The country rock is the Bradshaw granite, cut by numerous dikes. The strike of the veins is generally north or slightly east of north.

The three claims of the Starlight group lie about half a mile east of Venezia, at an altitude of about 6,600 feet. They were formerly owned by an English company, but are now the property of Tomlinson \& Son. The developments consist of three short tunnels with a vertical interval of 200 feet. In the upper tunnel the vein strikes N. $30^{\circ}$ E. and dips $60^{\circ} \mathrm{W}$.

The upper tunnel runs along the vein for 300 feet. The vein is 4 or 5 feet wide and carries several 6-inch streaks of heavy galena and zinc blende. These solid streaks are said to yield high assays in gold and silver. Some ore has been packed up to the Mount Union mill for treatment. There is said to be a shoot 270 feet in length along the tunnel.

The gangue is quartz filling with an indication of comb structure. In part the vein has been reopened and brecciated. Other gangue minerals are ankerite and fine-grained fluorite. Pyrite with coarsegrained black sphalerite and more or less galena make up the ore minerals. A dike of rhyolite porphyry of normal appearance shows 
in some places along the vein. Some of the breccia is cemented by galena and sphalerite.

The lower tunnel, 390 feet long, is inaccessible, but near the portal shows granite in the footwall and a rhyolite porphyry dike on the hanging wall side. It has not yet reached the ore shoot.

On the summit of the ridge east of Venezia, I am informed, there is a molybdenite-quartz vein, evidently of pre-Cambrian age but probably not of economic importance.

\section{CROOK VEIN}

The Crook is one of the strongest and most continuous fissure veins in the Hassayampa district. It has been worked with much success in the upper levels since the early days of the district. It crops out on the Crook claim, at an altitude of about 7,000 feet, in the upper part of Crooks Canyon east of the wagon road to Venezia. It is continued southward in the Harrison and is here 300 feet west of the Mount Union vein. The same vein is said to crop out at the Venezia mill and is here only 80 feet west of the Mount Union vein (Starlight group).

The country rock is mainly the Bradshaw granite, which here is decidedly gneissoid. The vein strikes N. $10^{\circ} \mathrm{W}$. and dips $75^{\circ} \mathrm{W}$. It has been worked along the outcrop, mainly by arrastres, for a distance of 4,700 feet, according to Mr. J. B. Tomlinson. In the main shoot of the Crook claim it has in places been worked to a vertical clepth of 220 feet. The workings are thus mainly in the upper oxidized zone; attempts to work the lower levels have not been generally successful. The vein follows a persistent 15 -foot dike of darkgreen rock, which lies on the hanging wall. The sulphide ore carries much galena and zinc blende and is generally like that of the Starlight veins (p. 123).

The last company that attempted the working of this vein was the Pan American Mining Co., whose operations ceased in 1902. The Crook Tunnel, at an altitude of about 6,700 feet, crosscuts the vein 160 feet below the outcrop, and drifts extend both ways. Since 1902 much work has been done on a small scale by lessees. The total production is estimated at. $\$ 250,000$.

Along the outcrop there is much oxidation, which probably nowhere reaches to a greater depth than 200 feet. The vein is said to be locally enriched by crossing fissures. There were no opportunities for examining the deeper workings. Ore from a 100 -foot shaft near the main tunnel proved to contain quartz veins 4 to 6 inches wide, with slender quartz crystals along the walls and a later filling of pyrite, galena, and sphalerite, in part altered to chalcocite. These sulphides are covered by crusts of later fine-grained quartz. The 
country rock here is a quartzose schist, only partly sericitized, composed of quartz and feldspar, perhaps a schistose phase of the granite.

Just below Venezia is Tomlinson's 20-stamp mill, erected to treat ore from the Crook vein. The vein has here crossed the canyon and has been developed by a 200-foot shaft. Apparently the enterprise aid not prove successful.

About half a mile below Venezia, in granite, the vein has been opened by a short tunnel on the west side just above creek level. The vein is here about 2 feet wide and was worked in 1922 under lease from Mr. Tomlinson. Very rich ore was encountered, consisting of quartz and sulphides, and several tons was sacked ready for shipment. A dike of rhyolite porphyry crops out in the creek bed below the tunnel.

There are several prospects in Crooks Canyon above Venezia in which the oxidized ore pans free gold.

\section{MOUNT UNION MINE}

From the divide a road turns off to the east which circles around the south base of Mount Union and ultimately reaches Poland Creek. The road crosses over into the Bradshaw granite, and many dikes of rhyolite porphyry appear along it as far as the Mount Union mine, which lies in a gulch 200 feet below this road. It is a quarter of a mile southwest of the summit of Mount Union, at an altitude of 7,400 feet, being thus the highest mine in the whole region. Several pre-Cambrian quartz-tourmaline veins also cut the granite. The vein, which is supposed to be an extension of the Starlight vein at Venezia, in Crooks Canyon, is developed by a shaft 800 feet deep and a lower tunnel. It has been closed for many years but was productive in 1906, yielding a lead concentrate with gold and silver. There is a small Huntington mill, which was run for a short time. The production was not large, though some statements assign a production of $\$ 200,000$ to the mine. The gold is said to have been difficult to amalgamate, and the ore is reported to be of low grade. The vein does not show well on the surface. The ore on the dump contains pyrite, sphalerite, and galena in quartz, in part well crystallized in long prisms, which project into the sulphides. There is also a dark-green pyritic rock on the dump which may have come from a dike following the vein. Close by a typical rhyolite porphyry dike crops out. It is reported that there were two veins in the property, one of them from 6 to 10 feet wide.

East of the Mount Union there are no evidences of mineralization until Poland Creek is reached. 
The old Consolidated Bodie mine, now belonging to the Murphy estate, is 4 miles below Palace station, in Crooks Canyon. It is mentioned in the Mint report for 1883, with the note that the ore is rich in lead, assays being given as 40 per cent of lead and 61 ounces of silver to the ton. There was then a tunnel 480 feet long and a shaft 100 feet deep. Since then there has been considerable development. The vein is contained in a large area of the Crooks complex and is probably of pre-Cambrian age. This property was not visited.

\section{OTHER PROPERTIES}

Four miles below the Bodie is the Circle Cross property. showing a 2-foot vein, with native gold and pyrite. The ore is said to be rich in places along foot and hanging walls. The strike is northeast, the dip vertical. E. W. Blaylock is the owner.

In the same vicinity are the 14 claims of the Arizona Central Mining Co., with headquarters on Crooks Canyon about a mile below Palace station. Some of the quartz veins, if not all, are of pre-Cambrian age. The Kentuck, 1 mile below Palace station, is a quartz vein as much as 2 feet wide, carrying some pyrite and chalcopyrite, with a little molybdenite. Assays of $\$ 15$ in gold and 3 ounces of silver to the ton are claimed. The strike is N. $10^{\circ} \mathrm{E}$., and the dip steep to the west.

There are several other veins of similar character which were not visited, and a "cross fissure" striking north, said to have a "lime-quartz" ganguie. On the Tom and Dick claim, to the east, toward Turkey Creek, is a 2-stamp mill and a shaft 175 feet deep, with a 500-foot drift on two levels.

\section{BIGBUG DISTRICT}

GENERAL FEATCRES

The Bigbug district, which is one of the oldest in the region, lies on the northeast slopes of the Bradshaw Mountains, extending from Bigbug Mesa down to the foothills of the Agua Fria valley. Its waters flow into Agua Fria River, and the altitude ranges from 7,000 to 4,500 feet. The upper slopes are timbered, but the foothills are generally open country. Some of the mines center about Poland, not far from the Walker district; others lie west of the Humboldt smelter. Still other's, mainly copper deposits in schist, lie between Humboldt and Mayer.

The predominating formation is the Yavapai schist, which here is mainly of sedimentary origin, with numerous embedded quartzite 
lenses. In many places, however, it contains interbedded schist of igneous origin. The schist, which strikes north-northeast, is intruded by the Bradshaw granite west of Poland and by a small mass of granodiorite (quartz diorite, according to Jaggar and $\mathrm{Pa}$ lache). There are also many dikes of rhyolite porphyry, with which certain of the deposits appear to be genetically connected. Basaltic flows later than any mineralization cover the top of Bigbug Mesa.

The ore deposits belong to five classes. (1) Pyritic copper deposits in schists are represented by the Blue Bell, Hackberry, Butternut, Boggs, and other mines. (2) Pre-Cambrian quartz veins are represented by the old Mesa mine, near Poland, and probably by several veins near McCabe. The age of some of these is in doubt. (3) A gold-silver replacement deposit, the Iron King, near Humboldt, carries tourmaline and is of an unusual type. (4) Veins of later date, most probably connected with the rhyolite dikes, are best exposed in the vicinity of Poland and Providence. The rich silver deposits with barite and calcite gangue about 2 miles west of the Humboldt smelter also belong to this group. (5) Placers have been worked in several gulches around McCabe.

Copper, gold, lead, silver, and zinc produced in Bigbug district, 1901-1924

[Compiled by V. C. Heikes, U. S. Geoolgical Survey]

\begin{tabular}{|c|c|c|c|c|c|c|}
\hline Year & Crude ore & Copper & Gold & Silver & Lead & Total value \\
\hline $\begin{array}{l}1901 \\
1902 \\
1904 \\
1905 \\
1907\end{array}$ & $\begin{array}{r}\text { Tons } \\
11,580 \\
13,425 \\
16,038 \\
23,939 \\
20,431 \\
60,369 \\
68,577 \\
13,429 \\
17,888 \\
37,837 \\
42,338 \\
23,480 \\
38,817 \\
56,690 \\
83,598 \\
76,118 \\
109,736 \\
141,339 \\
127,437 \\
116,184 \\
1,607 \\
26,571 \\
85,062 \\
10,385\end{array}$ & $\begin{array}{r}\text { Pounds } \\
70,000 \\
103,597 \\
155,833 \\
86,934 \\
210,423 \\
992,209 \\
1,399,127 \\
22,634 \\
319,816 \\
2,069,919 \\
2,733,644 \\
27,086 \\
2,010,633 \\
3,694,229 \\
4,285,668 \\
3,612,616 \\
6,774,730 \\
7,936,339 \\
5,716,132 \\
5,016,344 \\
981 \\
1,529,984 \\
4,874,836 \\
852,394\end{array}$ & $\begin{array}{r}\text { Fine ounces } \\
11,443.00 \\
12,046.00 \\
9,070.00 \\
19,788.60 \\
11,363.00 \\
21,545.45 \\
19,265.82 \\
7,801.46 \\
13,756.64 \\
5,161.41 \\
3,926.51 \\
1,965.88 \\
1,496.87 \\
2,431.38 \\
2,571.34 \\
3,468.29 \\
7,082.09 \\
10,989.22 \\
6,673.58 \\
5,905.16 \\
160.50 \\
1,409.05 \\
2,797.72 \\
694.72\end{array}$ & $\begin{array}{r}\text { Fine ounces } \\
58,533 \\
53,135 \\
94,877 \\
129,578 \\
99,336 \\
195,257 \\
193,380 \\
41,152 \\
72,495 \\
58,296 \\
63,423 \\
40,639 \\
37,965 \\
57,488 \\
\cdot 80,467 \\
98,182 \\
191,870 \\
254,027 \\
197,448 \\
182,495 \\
23,134 \\
54,862 \\
148,238 \\
20,184\end{array}$ & $\begin{array}{r}\text { Pounds } \\
285,000 \\
391,000 \\
732,359 \\
139,380 \\
384,880 \\
574,403 \\
443,182 \\
292,383 \\
337,184 \\
119,611 \\
67,106 \\
1,216,074 \\
17,296 \\
26,559 \\
78,170 \\
131,618 \\
256,194 \\
169,004 \\
206,656 \\
144,999 \\
102,226 \\
80,599 \\
207,357 \\
7,152\end{array}$ & $\begin{array}{r}\$ 295,613 \\
304,886 \\
292,072 \\
479,361 \\
346,514 \\
800,443 \\
\times 837,510 \\
198,349 \\
378,148 \\
406,324 \\
\text { a } 460,014 \\
\text { a } 260,394 \\
366,283 \\
574,421 \\
847,616 \\
\text { a }, 035,460 \\
2,176,035 \\
2,453,470 \\
1,433,252 \\
1,255,598 \\
31,178 \\
294,971 \\
910,505 \\
140,120\end{array}$ \\
\hline
\end{tabular}

a Includes zinc recovered: 1907, 140,786 pounds; $1911,8,913$ pounds; $1912,54,343$ pounds; $1916,10,255$ pounds.

\section{DEPOSITS NEAR M'CABE (CHAPARRAL DISTRICT)}

\section{IRON KING MINE}

A little more than a mile west of the Humboldt smelter, in the open foothills, is the Iron King mine, now owned by the Southwest Metals Co., which also owns the Humboldt smelter. To the officers of that company I am indebted for most of the following informa$68508-26-10$ 
tion. The deposit, which carries gold and silver, forms a replacement zone in the Yavapai schist, but it differs from the normal copper deposits that are so numerous farther to the south in the same schist. It was worked about 1906 and 1907. The production in 1907 was 1,253 ounces of gold, 35,491 ounces of silver, and 3,933 pounds of copper.

The deposit is developed by two shafts 750 feet apart and 435 and 225 feet deep. Several thousand tons of ore averaging $\$ 8$ a ton in gold and silver has been shipped to the neighboring smelter. It is claimed that the ore in sight amounts to 20,000 tons and that the deposit contains much low-grade siliceous material averaging $\$ 1$ or $\$ 2$ in gold to the ton. The ore is reported to contain from $\$ 6$ to $\$ 8$ in gold and 4 to 23 ounces in silver to the ton. Some diamond drilling has been done; the cores in the ore body contained $\$ 8$ in gold and 9.60 ounces of silver to the ton, 32 per cent of iron, and 14 per cent of insoluble matter. Other parts of the ore body contain as much as 70 per cent of insoluble constituents.

The deposit forms a series of lenses, in part overlapping, in highly silicified schist, which strikes N. $21^{\circ}$ E. and dips $75^{\circ} \mathrm{W}$. These lenses are 150 to 500 feet long and 5 to 10 feet wide. The whole mineralized zone is $\mathbf{7 5}$ feet wide.

The water level was found at a depth of 140 feet, and near this level in one ore body there was some enriched copper ore containing 4 to 5 per cent of copper.

The ore is a steel-gray flinty schist containing a crushed quartz mosaic of coarser and finer grain intergrown with some dolomitic earbonate and abundant prisms of bluish-gray tourmaline. The sulphides are disposed in streaks and consist of fine-grained arsenopyrite, pyrite, light-colored sphalerite, and a little chalcopyrite and galena. The arsenopyrite is the oldest of the metallic minerals.

\section{SILVER BELT MINE}

The old producer called the Silver Belt, which has been idle for many years, lies a few thousand feet southwest of the Iron King, in the same kind of schist. It is, however, a very different kind of deposit, carrying rich silver ore and being more or less similar to the deposit at the Peck mine, another of the old-time producers.

The Silver Belt was located about 1870 and was sold in 1878 to Thorne \& Simms. There were three shafts, one of them sunk to a depth of 252 feet in ore. The total production is estimated at 300,000 ounces of silver with more or less lead, but local statements run as high as 700,000 ounces. The vein was worked from 1870 to 1880 , and thus the mine is one of the oldest in the State. The ore was shipped to Ehrenberg and carried down Colorado River and thence to San Francisco. Later it was smelted at a local plant at Humboldt. In 
1906 the mine was reopened by H. B. Clifford, who was then sponsoring many mining enterprises in this region, and the shaft was sunk to 400 or 480 feet, but no rich ore was found. The vein is said to be 15 to 20 feet wide; the width of the ore was from 3 inches to 3 feet.

The country rock is amphibolitic schist, the strike of which is followed by the vein, N. $30^{\circ} \mathrm{E}$. The only feature now visible is a large scattered dump, evidently sorted over many times. The ore is mainly oxidized and dark by blackened manganese carbonate; it contains much manganiferous ankerite and much barite, with minor quantities of galena and sphalerite. Here, as at the Peck mine, the extreme concentration of oxidized silver ore near the surface and the evident poverty in depth are very remarkable.

The Cabinet claim adjoins the Silver Belt on the north, and a few carloads of silver ore has been shipped from it. Vanadium minerals are reported to have been found on the Lincoln claim, a short distance northeast of the Silver Belt.

Many of these statements referring to the Silver Belt were obtained from Mr. R. H. Burmister, the present owner, and from Mr. George Olsen, an old-time miner of the district.

\section{ARIZONA NATIONAL MINE}

About half a mile south-southwest of the Silver Belt is the Arizona National mine, which is owned by Anderson \& Co. and has been worked for 7 years. The mine is developed by a shaft 230 feet deep, from the bottom level of which there is a winze 185 feet deep. The property is equipped with a 50-ton ball mill and concentrating tables. High-grade ore and concentrates were shipped in 1922 and 1923.

The country rock consists of blocky amphibolite and some massive fine-grained diorite. The vein strikes N. $20^{\circ}$ E., dips $70^{\circ} \mathrm{W}$, and ranges in width from a few inches to several feet. The ore contains a little drusy milk-white quartz, some calcite, much palebrown ankeritic carbonate, with manganese and some barite. The ore minerals are galena and sphalerite, with a little pyrite and chalcopyrite. The massive galena contains about 100 ounces of silver to the ton, and the concentrates yield about 24 cents in gold. The source of the silver is seen in abundantly disseminated argentite in the galena, visible as microscopic dots after etching. There is also a black brittle mineral, which is later than the galena and gives reactions for silver, antimony, and copper. It was identified as silver-bearing tetrahedrite. Black coatings of argentite and abundant wire silver are visible in the cavities where secundary action has begun. 
It is not certain whether this vein is the southward extension of the Silver Belt. At any rate it belongs to the same type of deposit and affords excellent evidence of the character of the primary ore in these rich silver veins.

\section{LOOKOUT MINE}

About 1,500 feet south-southwest of the Arizona National is the Lookout mine, evidently on the same or a closely parallel vein. The vein strikes N. $40^{\circ}$ E. and dips $80^{\circ}$ W. A shaft 200 feet deep reveals similar ore to that in the Arizona National. The high-grade ore is reported to contain a little more gold, say $\$ 2$ or $\$ 3$ a ton, besides the predominating silver content.

This property is owned by Raible \& Mischeles, of Prescott. A concentrating test of 180 tons yielded 8 tons of concentrates containing $\$ 80$ to the ton. The Lookout vein can be traced 1,500 feet toward the McCabe mine, and some believe it is the same vein.

\section{MCCABE-GLADSTONE MINE}

The McCabe-Gladstone mine, on Galena Gulch, is one of the deepest in this region and has a large production to its credit. It was closed in 1922 and has not been operated since the period from 1898 to 1913, when it was continuously worked by the Ideal Leasing Co. In 1907 the production was 12,000 ounces of gold and 117,500 ounces of silver, having a total value of $\$ 397,212$. The present owners are reported to be Arthur Turnbull and Charles M. Chapin, of New York City. I am informed by Mr. Turnbull that the total joint production of the Gladstone from 1903 and the McCabe from 1906 to the present is $\$ 1,541,673$. Mr. Turnbull believes that the production prior to that time would range between $\$ 1,000,000$ and $\$ 1,500,000$.

The property, which includes eight claims extending northeastward, consists of two principal mines, the McCabe, on the east, and the Gladstone, on the west. It is developed by two shafts, the Gladstone, 1,100 feet deep, and the McCabe, 900 feet deep.' They are about 800 feet apart. The total developments aggregate several miles in length. (See fig. 8.)

The country rock is an amphibolitic schist, intruded a short distance to the south by a small mass of coarse-grained quartz diorite. Between McCabe and Huron siding a 20-foot dike of rhyolite porphyry intersects the schist, and between the two shafts there is another dike of the same rock about 20 feet wide and having a northerly strike. The vein strikes N. $54^{\circ}$ E. and dips $79^{\circ}$ SE., but between the two shafts it is interrupted by the porphyry dike just mentioned. The geologic relations are not clear at present, the workings being inaccessible. Apparently the veins are deflected toward 


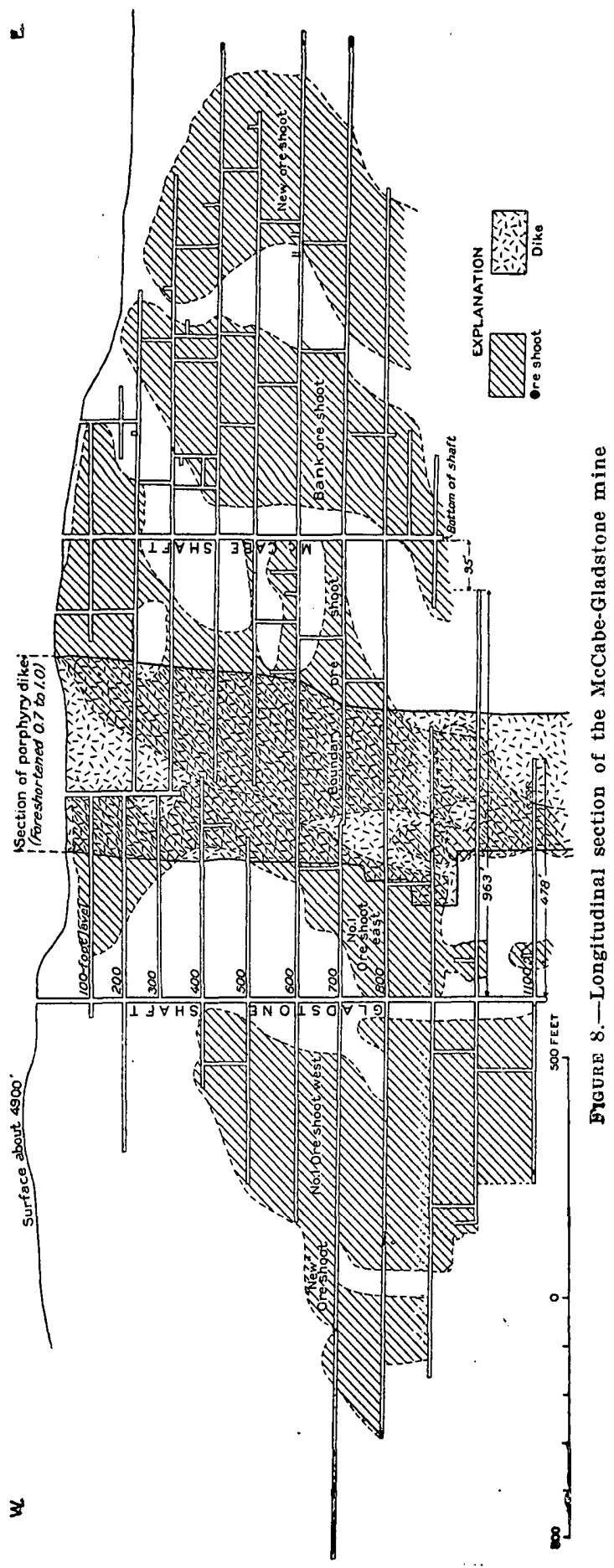


the south by the dike, but where they pass through this dike the ore seems to be, in part at least, of normal grade.

There are five ore shoots along the vein, each of which has a stope length of 200 to 500 feet. At least two of the shoots appear to reach the 1,100-foot level in the Gladstone mine. These shoots pitch steeply toward the west. The average width of the ore is somewhat less than 1 foot; the vein averages $31 / 2$ feet in total thickness.

The ore contains quartz, which is rather massive but is drusy in places. Jaggar and Palache say that it is distinctly banded, the sulphides occupying the central part of the fissure. There are considerable amounts of sulphides, mainly pyrite and arsenopyrite, with a little sphalerite, galena, and chalcopyrite. The presence of tetrahedrite is suggested by the analysis. The analyses of the shipping ore and the concentrates are about alike and run somewhat as follows:

Average analysis of shipping ore and concentrates from McCabe-Gladstone
mine

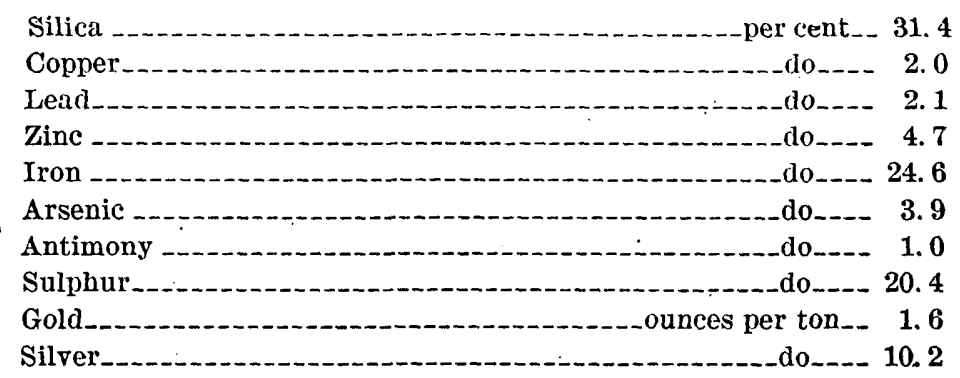

The mill concentrates contained in 1907, for instance, 1.1 ounces of gold and 4.1 ounces of silver to the ton. The ore is said to contain also some bismuth.

\section{PROPERTIES NEAR THE GLADSTONE}

The Gladstone is adjoined on the southwest by three claims-the Gladstone Western Extension, Little Kicker, and Rebel. These lie in a wedge of schist included in quartz diorite and have not been worked for many years. Jaggar and Palache say that the Rebel vein occupies a zone of brecciation in quartz diorite or alkali granite and contains largely gold in sphalerite, galena, and pyrite; quartz and dolomite form the cementing matrix.

There are many other properties on the divide between Galena Gulch and Chaparral Creek. Among them the Little Jessie, Dividend, and Lelan are the best known. The Jessie, which at one time was consolidated with the Union, was worked more or less continuously from 1903 to 1915 . Up to 1903 it is said to have had a total production of $\$ 750,000$. Between the 500 and 600 foot levels 
much high-grade auriferous pyrite was encountered. The shaft is 659 feet deep. The ore contains from $\$ 10$ to $\$ 20$ in gold to the ton and very little silver.

The Dividend and the Lelan were worked more or less from 1900 to 1914 . They are provided with a 10-stamp mill, which is reported to be dismantled. The ore production is probably at least 10,000 tons, containing from half an ounce to 3 ounces of gold to the ton. The ore contains also a little silver and some copper and lead.

All the veins mentioned above have an east-northeasterly strike. Going north from the McCabe one crosses successively the Little Jessie, Dividend, Paymaster, and Lelan or Union veins. The Little Jessie is about 1,700 feet south of the Union vein. The Lelan and Dividend properties are owned by Judge Wells, of Prescott.

\section{UNION MINE}

The Union mine was in active operation in 1922 by the Union Consolidated Mines Co., R. C. Kaiser, in charge. It is claimed that the Little Jessie and Union properties when consolidated had a total production of $\$ 800,000$. The present workings are in the upper part of Chaparral Gulch at an altitude of about 5,000 feet. There is a 50-ton flotation mill on the property.

From McCabe up to the Union mine the country rock is a fissile amphibolite. At the Union mine the principal rock is sheared Bradshaw granite, but the Yavapai schist is not far away.

The property is developed by a 1,200-foot tunnel that penetrates the ridge. The main portal and the mill are on the north side. The Union vein, which is the northeast continuation of the Lelan vein, is cut about 200 feet from the north portal, and drifts have been run upon it for 800 feet toward the southwest and a shorter distance toward the east. A shaft has been sunk from the tunnel level at a point 500 feet west of the crosscut to a depth of 200 feet, but so far only one level, 77 feet below the tunnel, has been opened from this shaft.

The vein strikes about $\mathrm{N} .70^{\circ} \mathrm{E}$. and dips steeply southeast. In places the quartz is 10 feet thick. It is followed by a basic dike about 4 feet wide; evidently the dike is intruded in the vein and it may be found on either side of the vein. It is fresh and nonmineralized except for some films of pyrite on the contacts.

The ore consists mainly of massive glassy quartz, as much as 10 feet thick, with irregularly disseminated pyrite, arsenopyrite, sphalerite, and galena; the quartz is not drusy and not banded. The gold is not free except in the oxidized zone. On the tunnel level and on the 77-foot level the ore shoot is cut and is said to be 250 feet long and to pitch about $30^{\circ} \mathrm{SW}$; ore has also been found in the northeast 
face of the 77-foot level. The lower limit of ore is said to be about $\$ 10$ a ton.

Near the north portal the Blaine vein has been intersected; here it is close to the Union vein but toward the east it diverges. It strikes N. $50^{\circ} \mathrm{E}$. and has a steep northwest dip. This is a narrow vein with dolomitic gangue; in places it carries a 6 -inch streak on. the footwall with partly oxidized tetrahedrite, said to contain 150 ounces of silver to the ton. Evidently the Blaine vein differs in age from the Union vein, and probably it is much younger.

\section{PROPERTIES ON BIGBUG CREEK NEAR PROVIDENCE AND POLAND}

The general southwest strike of the McCabe and Chaparral vein systems carries them toward the headwaters of Bigbug Creek. At Providence and Poland there has been considerable activity in the past. Very little work was done in 1922. Repairs were made on the old track from Poland Junction to Poland and on the 11,000-foot tunnel that traverses the ridge to Walker to form an outlet for the ores of that district. The wagon road up Bigbug Creek to Poland had been allowed to go to ruin, and Poland was accessible only by trail. This is a striking example of the decay of the district.

Up Bigbug Creek a small area of quartz diorite is crossed about a mile below Providence; here the rock is darker than elsewhere and shows uneven grains. Near the east contact is a dike of "quartz porphyry" mineralized to some extent and showing copper stains. The ore is of low grade, and there are few developments. On the west side of the quartz diorite the country rock is a blocky greenstone, showing agglomerate structure in places and only slight schistosity where exposed in the creek bed. On the slopes the rocks show much more clearly the inherent schistosity.

Providence has the sad aspect of a practically defunct mining town, though at one time it evidently presented a scene of great activity.

A number of claims on veins striking east-northeast lie on the south side of the gulch. Among them are the Sterling and the Seventy-nine. The Sterling vein is stated to have yielded a considerable amount in bunches of gold-silver-copper ores, and is developed to a depth of 400 feet. It is mentioned in the Mint report of 1886 , when a gold mill was erected. The oxidized ores of many of these veins have been worked by arrastres, and this species of reduction plant is not wholly extinct in the vicinity. At present the most productive veins near Providence are the Mammoth-Bel-1 cher-Red Rock vein and the Fortuna vein.

The Fortuna, now the property of the Boone County Mining \& Milling Co., strikes east-northeast and is about half a mile northeast of Providence, on the north side of the creek. It is parallel to the Red Rock vein and lies about a quarter of a mile east of it. The 
Fortuna is developed by a shaft and several tunnels and has a 10-stamp mill erected about 1915. The vein is 2 to 3 feet wide and shows much drusy quartz and pyrite in good crystals. The center of the vein is in places filled by calcite, and the quartz is brecciated by it. This vein continues west-southwest down to a point near Bigbug Creek.

The Red Rock vein, on the slope above Providence, is contained in fissile weathered amphibolite schist. The vein, which follows the schist, strikes N. $35^{\circ}$ E. and dips steeply southeast. It was worked about 1906 and is developed by several tunnels, all now more or less caved. On the Belcher claim, farther northeast, is a shaft 235 feet deep, which is tapped by the lowest Red Rock tunnel along the railroad track. Where seen the vein was 2 feet wide, was partly oxidized, and contained veinlets of drusy comb quartz with well-crystallized pyrite and some zinc blende. Most of the ore mined came from the oxidized zone, which is richer in free gold. It was reduced in an amalgamating mill with tables, still visible on the property. The primary ore is probably of low grade. It is reported to contain from $\$ 4$ to $\$ 5$ to the ton in gold.

From Providence to Poland, a distance of 2 miles, not much mineralization is seen. However, half a mile above Providence the road crosses a 30 -foot dike of normal rhyolite porphyry, and a few feet away, in the schist, is a prospect on a silver vein, with manganese and barite.

On the slopes north of the road are two veins, the Postmaster and the Merchants Home, both striking northeast, which have been worked to some extent. Ore from the Postmaster was still lying on the platform of the Oriental custom mill, close by the road. This ore shows crusts of quartz crystals on which are deposited dark sphalerite, galena, and pyrite. Mr. Ed. Block, of Prescott, who operated the Merchants Home as the Merchants Mining Co., states that the shaft is 300 feet deep, with levels at 100, 165, and 240 feet. The ore carries mainly silver, and in places 2 feet of massive galena showed. On the 300 -foot level the vein is said to have been 20 feet wide. In all, I am informed by Mr. Block, 1,000 tons of crude ore was shipped from the property. The Taylor property, close to the road, is of the same general type. The Lottie is another vein in this vicinity on which much shallow work has been done.

The Copper Dike property lies 2,000 feet west of the Merchants Home. According to Mr. Block this property is located on a copper-bearing schist belt 75 to 100 feet wide. Specimens show coarse amphibole, with some quartz, chalcopyrite, azurite, malachite, native copper, and bornite. The property is developed by a 250 -foot tunnel and a crosscut. 
Near Poland the appearance of the country becomes attractive and picturesque. The forested slopes rise boldly on the south to the Bigbug basalt mesa, which attains an altitude of 7,000 feet; the summers are cool, and there are several little clearings with alfalfa and fruit. A switchback carries the railroad track up to the south portal of the 11,000-foot tunnel. Here the amphibolite borders against the somewhat schistose Bradshaw granite, through which the tunnel is driven. Just west of the portal a 75-foot dike of rhyolite porphyry crops out (p. 23), striking N. $30^{\circ}$ E. The tunnel intersected several veins, which have been somewhat extensively worked.

The Poland vein was cut 800 feet from the south portal, and the Poland, Hamilton, and Belle claims are located on it. The Poland property is owned by the Murphy estate. Quartzose ore from this vein still lies on the dump. It shows drusy quartz crusts with pyrite and some sphalerite and galena. The vein strikes northeast and dips steeply northwest. A 20-stamp mill on the property was started in 1900 and worked intermittently until about 1912. In 1905 the output was about 75 tons of ore a day. In 1907 it is recorded as producing $\$ 130,465$ in gold and 16,609 ounces of silver. There has been a great production, probably mostly in silver; the value of the output is estimated at $\$ 750,000$. A shaft was sunk, it is said, to a depth of 325 feet below the tunnel level.

The Accidental vein, carrying gold, silver, and lead, is said to have been cut 500 feet from the north or Walker portal; from accounts this was similar to the Poland vein and was followed to a depth of 200 feet below the tunnel level. It had some production.

The old Mesa mine is on the slopes south of Poland. There is little to see there now, but it is stated that the ore worked in arrastres yielded a considerable production of gold in the early days. It is now owned by Ed. Block, of Prescott. A 700-foot tunnel was driven by Mr. Block in 1904 and showed the vein 4 to 6 feet wide disturbed by basaltic dikes. The quartz was spotted but free milling, and the total yield from the deposits is said to have been absut $\$ 40,000$. The gold was of high grade, $\$ 19$ to $\$ 20$ an ounce, and placer gravel was found below the vein. Evidently this vein is of pre-Cambrian age.

In the canyon above Poland are several veins, which have been prospected at intervals. They were not visited. The Blue Rock and Money Metals veins are 1 mile above Poland; the Express,' a parallel vein, is half a mile above the town. Several of these veins have some ore production to their credit. 
The Henrietta mine, now belonging to the Big Ledge Copper Co., is an old-time property on the north slope of Bigbug Creek, where the stream turns from an easterly to a southerly direction. (See pl. 12,B.) It is about 4 miles north-northwest of Mayer. The old workings show on the upper slopes on the ridge, and much ore was extracted from them. This mine is the same that in the old Mint reports of 1883 and 1884 is referred to as the Big Bug mine, then the most prominent producing property in the country. The total production, mainly from the oxidized gold ores from the upper levels, is high. The vein, unlike most of the others in this district, strikes north, and dips about $70^{\circ} \mathrm{W}$. There is also a spur striking north-northeast, called the Invincible. The Henrietta claim is continued northward by the Gopher, and these are the two principal claims.

The old developments consist of a shaft 500 feet deep sunk from the summit of the ridge at an altitude of 5,700 feet. The upper tunnel, at 5,480 feet, is about 1,800 feet long and traverses the ridge. The lower tunnel, at 5,150 feet, is 2,200 feet long, and near its end a vertical shaft is sunk to a depth of 600 feet, with levels extending a few hundred feet northward (fig. 9).

The northern extension on the Gopher claim is developed by several shafts, each a few hundred feet in depth, and these workings are almost entirely in the oxidized zone. The ore shoots appear to dip steeply northward. The main shaft at the end of the lower tunnel penetrates primary ore, and there are said to be stopes on the several levels (fig. 9) down to the 450 -foot level.

The mine was worked extensively in early days, when the deep oxidized zone provided gold ore. It was also in operation from 1914 to 1919 .

There is a 100-ton flotation mill on the property, consisting of a crushing plant, tube mills, and flotation cells, but this mill is reported to be dismantled since 1922 .

In 1922 the property was idle. The present company has done most of the deeper development work.

To the manager of the company, Mr. W. W. Lytzen, I am indebted for much information.

The rock containing the vein is, according to Jaggar and Palache, a hornblendic variety of the Yavapai schist, on the east side of a small area of quartz diorite. There seems to be much complication, however. Most of the rock is a dark fine-grained diorite or amphibolite, and massive rather than schistose. One specimen proved to consist of abundant quartz mosaic with irregularly distributed diop- 


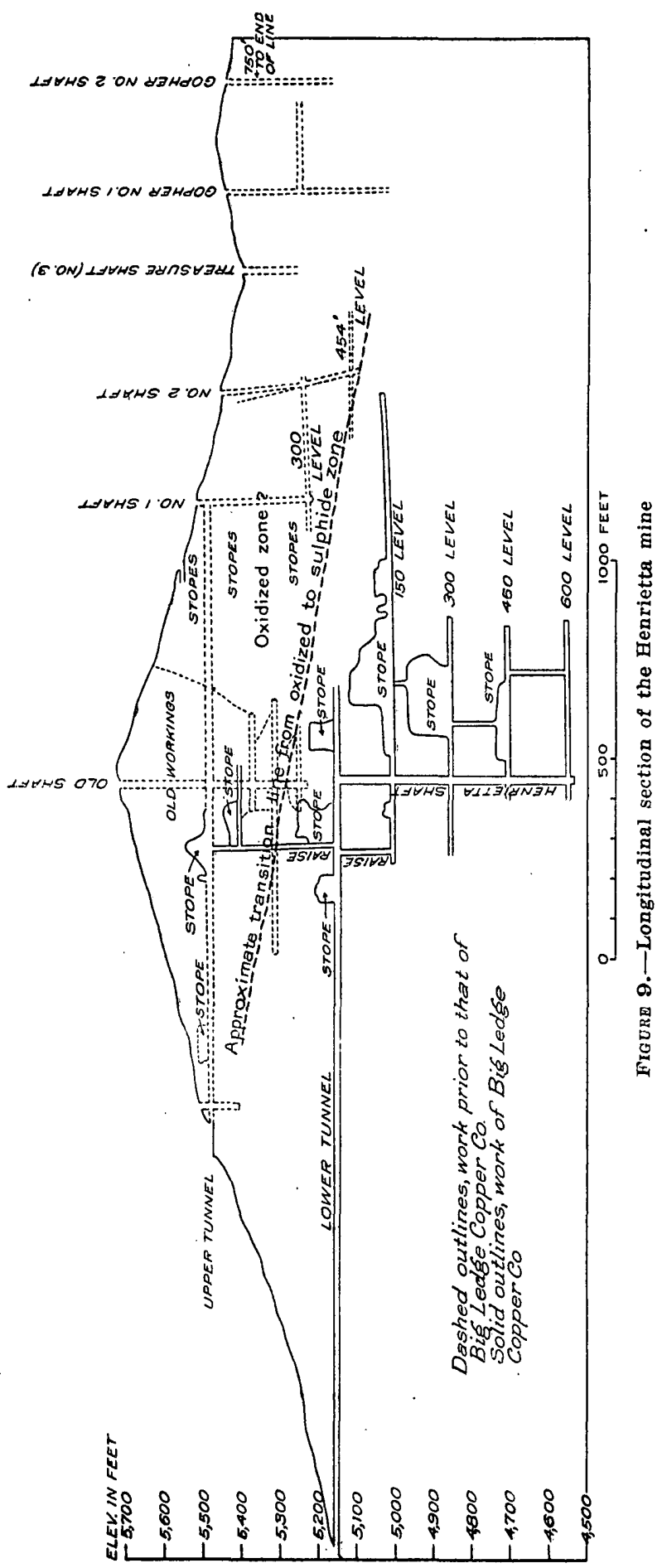


side or light-colored augite and magnetite, looking like a product of igneous metamorphism on calcareous rocks.

The deposit is a well-defined quartz vein about 6 feet wide between walls. In the lower tunnel it is small and locally pinched almost to the interior shaft. Here a solid quartz vein 2 feet wide with massive sulphides was exposed. In stopes on the 150-foot level a 5 to 6 foot vein was exposed, still showing slight oxidation. The lower levels were inaccessible. About 60 per cent of the ore consists of sulphides, mainly pyrite and chalcopyrite, with lesser amounts of a light-colored sphalerite and galena. The ore is said to average $\$ 8$ to $\$ 10$ in gold and 5 per cent in copper. The quartz is massive, rarely showing drusy texture. In places it contains later calcite. The sulphides are locally arranged to form a rude banding. The ore in the back of the stopes from the 600 to the 450 foot level is said to have given average assays as follows: Copper, 3.2 per cent; iron, 14 per cent; insoluble matter, 60 per cent; gold, 0.2 ounce to the ton; silver, 2.7 ounces to the ton.

The northward continuation of the Henrietta would intersect the McCabe vein. It is evident that the primary ore is of low grade, but it may be found to be workable. I am not entirely certain as to the classification of this deposit. It is not like the normal pre-Cambrian veins, and it differs in many respects from the drusy veins that are so common in the district and are distinctly related to the rhyoliteporphyry dikes.

Evidently the ore has been greatly enriched by oxidation.

\section{BOGGS MINE}

North of the old Iron Queen dumps, 1,500 feet across Boggs Flat, is the Boggs mine. For many years this property, with the Iron Queen, Hackberry, and Senator, was operated by the Commercial Mining Co. (present Phelps Dodge interests), and the ore was treated in a local smelter near Mayer. From about 1905 to 1909 the properties were worked by the George A. Treadwell Co., and the ore was treated in a new 250-ton smelter at Mayer. The buildings still stand south of the town. Since this company went into bankruptcy the mines have remained closed.

The dumps are extensive and show many varieties of rock. Most of the schist, however, is of sedimentary origin and appears as siliceous brownish hornfels weathering to light-colored sericitic schist. Some of the schist is chloritic and amphibolitic. The strike, as usual in this region, is N. $20^{\circ} \mathrm{E}$, and the dip steep to the east. Much copper ore has been extracted from the mine. The deepest workings are on the 500-foot level; here some good ore still remains, it is said, though the bulk of it seemed to go over into soft pyrite. 
It is not possible to present a full description of this deposit, but the specimens from the dump show several interesting features. Most of the ore was undoubtedly of the type similar to that of the Blue Bell mine-that is, schist replaced by pyrite and chalcopyrite. The schist is largely quartzose and consists of a quartz mosaic, with mica, chlorite, and amphibole, but there are also veinlike masses of white coarse quartz, surrounded by rims of garnet, epidote, and a fine felted radiating amphibole. These masses contain sphalerite and arsenopyrite in crystals; locally there are also masses of calcite with crystallized bournonite. This occurrence is mentioned in Dana's "System of mineralogy."

Evidently the schist contained calcareous bands, and these have been converted to lime silicates by the injection of high-temperature siliceous solutions, followed by some mineralization. The silicates replace the quartz mosaic, and the sulphides replace both quartz and silicates. The deposit thus shows the effect of mineralization at two periods, and perhaps a third is indicated by the calcite and bournonite.

\section{IRON QUEEN MINE}

The former activities at the Iron Queen mine, on the south side of Boggs Flat, are now indicated only by extensive dumps. The property once operated by the Commercial Mining Co. has been idle for many years. The shaft is 300 feet deep. The country rock, as shown on the dumps, is rusty schist impregnated with pyrite. The rock is a fine-grained hornfels. A thin section of one specimen showed a fine-grained aggregate of quartz, albite, and chlorite. Replacing this groundmass are aggregates of fine-grained calcite. Both matrix and calcite are replaced by irregular masses of yellowish garnet, some epidote, needles of actinolite, and some magnetite. The rocks are thus very similar to those of the Boggs mine. The ore minerals, which replace all others, are pyrite, chalcopyrite, sphalerite, and a little galena and specularite. Here too the dynamic metamorphism of calcareous and siliceous sediments was probably followed by igneous metamorphism producing garnet and some sulphides, and by a third alteration resulting in impregnation of the schist by pyrite and chalcopyrite. The ore was of low grade, containing 2 to $23 / 4$ per cent of copper, 38 per cent of iron, and 50 cents in gold and 1 ounce of silver to the ton. It was used mainly as a flux for richer ore.

The occurrence of marcasite in this ore is an interesting feature. This mineral is found in the partly oxidized ore, and possibly its development just preceded the active oxidization and it was formed by descending solution. The marcasite occurs in small reniform masses, which replace sphalerite, pyrite, and gangue. As shown by the 


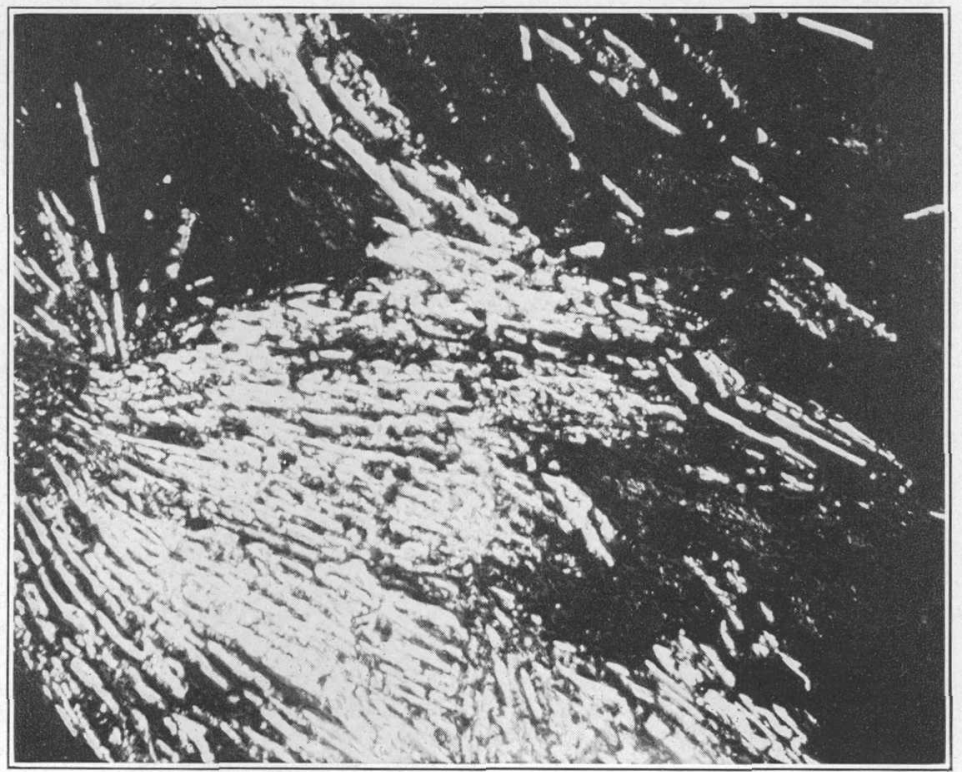

A. ORE FROM SWALLOW MINE, CASTLE CREEK DISTRICT

Specularite (light) developing in chrysocolla (dark) Enlarged 110 diameters

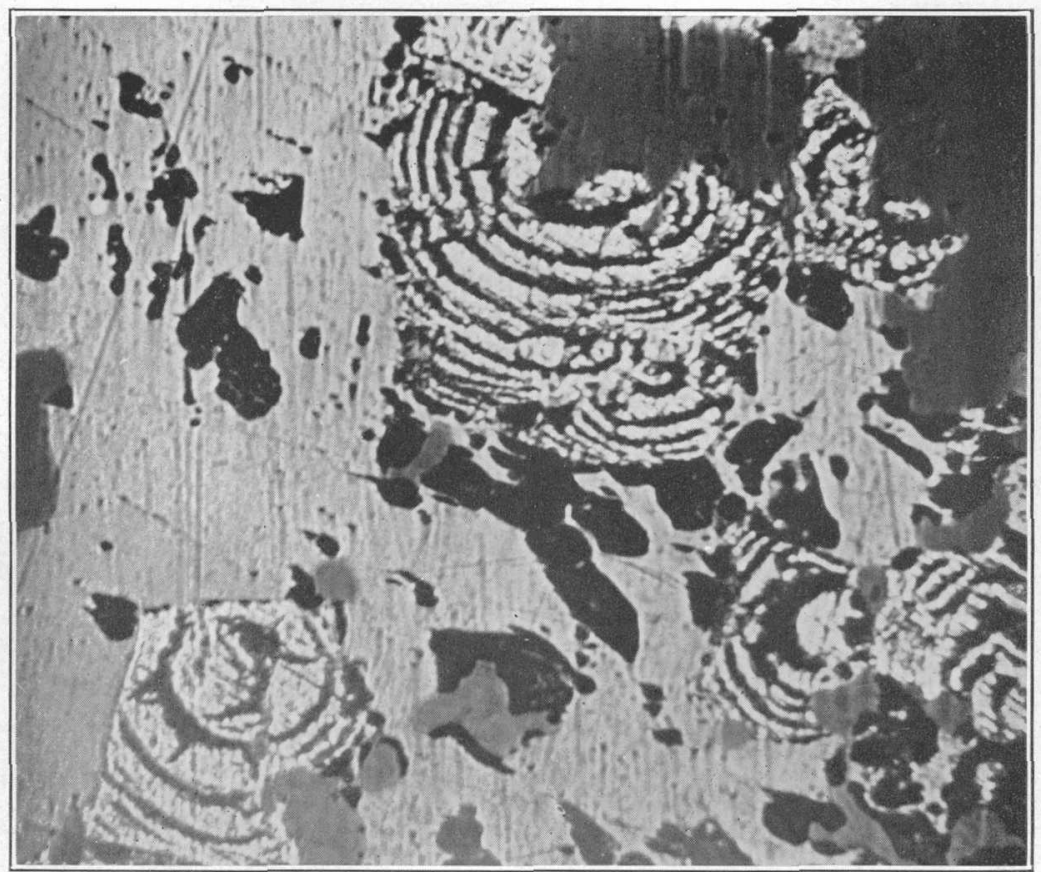

$B$. ORE FROM IRON QUEEN MINE, MAYER

Colloform marcasite replacing sphalerite (gray) and gangue (black) Enlarged 130 diameters PHOTOMICROGRAPHS OF POLISHED SECTIONS SHOWING ORES 
photograph (pl. 15, B), there are open spaces between the concentric structures, suggesting that a colloid of iron sulphide has replaced the minerals, later taking up sulphur and crystallizing as marcasite. 'The character of the replacing solutions and the chemical reactions have not yet been fully elucidated. The solutions could not have been acid, for they replaced quartz as well as sulphides.

\section{HACKBERRY MINE}

The schist belt of the Boggs and Iron Queen mines extends northward toward Humboldt, near which the old Huron mine was located. There is little to be seen of these old workings.

To the south the schist belt passes 2 miles north of Mayer, just north of the old Boggs smelter, and continues northwest of Mayer to the Mayer-Pentland and Hackberry mines. At the Pentland mine is a large dump of chlorite schist, showing in places a little chalcopyrite, pyrite, and arsenopyrite, with quartz and ankerite. Rather extensive exploration evidently failed to reveal large bodies of sulphide ore.

At the Hackberry mine, formerly owned by the Commercial Mining Co. and later by the George A. Treadwell Co., much work has been done. The mine has been idle since 1909 and the gallows frame is slowly decaying. George A. Treadwell opened it with W. S. Logan and Colonel Green, of Cananea, after having bought it from the Phelps Dodge interests. The depth of the shaft is 900 feet, and the ore carries copper with a little gold and silver.

The dumps show mainly chloritic schist, which in thin section discloses a quartz mosaic with abundant parallel strings and foils of green chlorite, some sericite, a little biotite, and later metacrysts of epidote. Magnetite and apatite are also present. In part the schist is distinctly quartzitic.

Rock of another type contains abundant magnetite cemented together by a mosaic of radial amphibolite and quartz. Probably there is also some garnet in this rock. This locality, therefore, presents the same indications of igneous metamorphism as were observed at the Boggs and Iron Queen mines. The ore minerals impregnating the schist are pyrite and chalcopyrite, with minor amounts of galena and sphalerite, accompanied by a gangue of quartz and ankerite. Tetrahedrite was also observed. The mineralization was essentially that typical for these deposits, and it is believed that actinolite and magnetite are products introduced at an earlier date before the sulphide mineralization.

It looks as if the Hackberry mine had produced a considerable amount of ore. 


\section{BUTTERNUT MINE}

Another belt of mineralized schist lies about 2 miles west of the Boggs-Hackberry line. Outcrops of this belt are shown near Huron siding in some old workings with oxidized ore containing chrysocolla. More work has been done at the Butternut mine, about a mile south of the Henrietta at Bigbug, by the Big Ledge Copper Co. The oxidized zone at the Butternut is said to have been rich in gold, and in the early days many shipments of such ores were made. The developments include an inclined shaft 425 feet deep, starting with a dip of $70^{\circ}$ and flattening out somewhat below. The lowest level extends about 600 feet north and south of the shaft.

The deposit crops out on the upper slopes of a rolling ridge between Grapevine and Bigbug creeks. The outcrops consist of silverywhite sericite schist-_" gravestone schist"-and the beds strike $\mathrm{N}$. $50^{\circ} \mathrm{E}$. and $\operatorname{dip} 70^{\circ} \mathrm{SW}$. In depth the rocks become less schistose and assume a dark-gray, green, or brown tinge. Thin sections show that both igneous and sedimentary rocks are present. Some are clearly basic igneous rocks altered by dynamic metamorphism. They contain chlorite, magnetite, quartz, albite, and epidote and smaller amounts of sericite, titanite, apatite, and tourmaline. The general matrix is a fine mosaic of quartz and albite with patches of chlorite and magnetite. Other rocks are quartz-chlorite-sericite schist, which is surely of sedimentary origin.

The ore minerals occur in lenticular streaks with quartz mosaic and chlorite and consist of pyrite, chalcopyrite, sphalerite, and a little arsenopyrite. The ore is said to be of low grade, though some of it has been shipped. The mine is reported to contain some reserves of such low-grade ore.

\section{POCAHONTAS MINE}

The property of the Pocahontas Copper Queen Mining Co. is 3 miles southeast of Mayer, where a patented group of four claims carries a gold-copper ore, apparently belonging to the pyritic impregnations in schist. A 200 -foot shaft is sunk on this deposit.

The Spar group of 10 claims is developed by two shafts 100 and 200 feet deep. A 50-ton concentrating mill is erected on the property. This deposit is a $21 / 2$-foot vein of uncertain relations, dipping $55^{\circ} \mathrm{NW}$. and occurring in a dark schist. The ore contains tetrahedrite that carries gold and silver; it also contains galena and pyrite. The gangue is quartz and calcite. Selected samples yield as much as $\$ 150$ a ton, and the ore is said to average $\$ 49$. This small mill was in operation in 1922. Under former management shipments of 23 carloads gave sufficient returns to pay the purchase price and cost of 
development. The mill was installed in 1920 and is reported to yield a concentrate containing 44 ounces of silver and $\$ 10$ in gold to the ton, besides 6 per cent of copper and 11 per cent of lead..$^{40}$

\section{BLUE BELI, MTNE}

History.-The Blue Bell mine has for many years been the property of the Consolidated Arizona Smelting Co. and has yielded a large quantity of low-grade pyritic copper ore. It is now held by the successor of this company, the Southwest Metals Co., which also operates the Humboldt smelter. Jaggar and Palache in 1901 mentioned the property briefly, but it was not until 1906, when the mine was transferred to the Consolidated Arizona Smelting Co., that it began to acquire importance. Since then it has developed into the largest producer in the Bradshaw Mountains. The total production of ore to 1921 , inclusive, was 800,000 tons of copper ore, with an average gross value of $\$ 10$ a ton. In common with many other mines the property was idle in 1921, but it reopened in 1922 at the same time as the Humboldt smelter.

Development.-The Blue Bell mine is 4 miles south of Mayer, at an altitude of 4,500 feet. (See pl. 18, A.) It has modern, electrically driven equipment and is connected with the railroad siding by an aerial tram 1 mile long. There is a concentrating plant of 350 tons capacity at the Humboldt smelter. The developments consist of a vertical shaft 1,400 feet deep in 1922 with almost 30,000 feet of workings north and south. There are five smaller shafts.

Production.-The total output since 1906 of about 900,000 tons has in recent years been distributed as follows, according to the published figures of the company:

Copper, gold, and silver produced at Blue Bell mine, 1903-1925 [Compiled hy V. C. Heikes, U. S. Geological Survey]

\begin{tabular}{|c|c|c|c|c|c|}
\hline & Year & Crude ore & Copper & Gold & Silver \\
\hline 1903. & & $\begin{array}{r}\text { Tons } \\
392\end{array}$ & $\begin{array}{l}\text { Pounds } \\
\quad 43,120\end{array}$ & Fine ounces & $\begin{array}{r}\text { Fine ounces } \\
921\end{array}$ \\
\hline $\begin{array}{l}1904 . \\
1905\end{array}$ & & (n) & 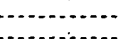 & $\cdots$ & - \\
\hline $\begin{array}{l}1900 . \\
1906 . \\
1907 .\end{array}$ & & $\begin{array}{r}4,452 \\
18,342\end{array}$ & $\begin{array}{l}204,230 \\
789.731\end{array}$ & $\begin{array}{l}204.00 \\
640.59\end{array}$ & $\begin{array}{r}4,855 \\
16,007\end{array}$ \\
\hline 1908. & (1) & & & & \\
\hline 1909. & ................ & 1,175 & 82,250 & 59.00 & 3,055 \\
\hline 910. & .... & 26,726 & $1,997,166$ & $1,342.00$ & 39,937 \\
\hline 1911. & $\ldots . . .$. & 35,783 & $2,667,332$ & $1,925.20$ & 50,344 \\
\hline - & - & 22,741 & $1,157,008$ & 822.25 & 24,347 \\
\hline 1913. & $\begin{array}{ll} & \end{array}$ & 37,812 & 1,976 & $1,021.00$ & 30,65 \\
\hline & 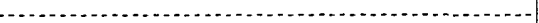 & 058 & & 1,87 & 55,3 \\
\hline & . & & & 1,88 & 64,8 \\
\hline & $\ldots . . . .$. & & & 2,89 & \\
\hline & & 102,773 & & 6,06 & 150,116 \\
\hline & & 131,090 & $7,263,779$ & 8,25 & 202,995 \\
\hline 18 & 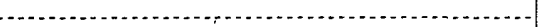 & 122,069 & $5,546,996$ & 5,59 & 144,501 \\
\hline 1920. & $\ldots$ & 111,749 & 89,565 & 4.00 & 129,560 \\
\hline & $\ldots$ & & & $\overline{42}$ & 29,058 \\
\hline & & & 4,855 & 2,600 & \\
\hline & & & & & \\
\hline & 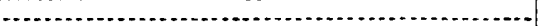 & 13,454 & 683,771 & 846.23 & 20,767 \\
\hline
\end{tabular}

49ed, W. H., Mines Handbook, 1922. 
Geology.-The deposit is contained in the Yavapai schist, which here is of complex character, including ledges of quartzite, biotite schist, small lenses of crystalline limestone, chloritic schist, clay slate, and schistose quartz porphyry. The strike is N. $27^{\circ} 30^{\prime} \mathrm{W}$. and the $\operatorname{dip} 70^{\circ} \mathrm{W}$.

A reef of brownish quartzite crops out prominently at the village below the mine, and close by is some light-gray fissile clay slate. Quartzite also occurs on the 1,400-foot level. Another specimen collected from the same level is a dark-green dense schist which looks like hornfels and contains dirty-green biotite, magnetite, zoisite, chlorite, and quartz mosaic. Still another specimen from the same level is a greatly crushed quartz porphyry with microcrystalline groundmass of quartz and orthoclase, with some microcline, albite, and sericite. The quartz phenocrysts are also greatly crushed.

Veinlets of calcite and quartz are abundant in the mine. A persistent dike is exposed on all levels and is not affected by schistosity. A thin section of this dike shows partly idiomorphic augite, brown hornblende, some of it with kernels of augite, lathlike labradorite, magnetite, and apatite. Secondary chlorite and sericite are present. The grains average 1 to 2 millimeters in size. This is a granular dike rock related to camptonite. This dike is generally vertical and intersects ore about 200 feet south of the shaft. It shows no mineralization.

The ore body.-The ore body is essentially a silicified and mineralized zone that conforms to the schist. The width is about 100 feet. The ores form a series of about six flat lenses within the zone; in part they overlap and they pitch about $75^{\circ} \mathrm{S}$. in the zone. These lenses are as much as 40 feet wide and occur on both foot and hanging walls.

The stopes stand well; some of them are 80 feet high and 20 feet wide. Relatively to the walls of the zone, each shoot keeps its position well. Most of them continue from points near the surface down. The surface is generally barren, probably as a result of leaching. The fourteenth level was just opened in 1922. The developed length of the deposit is 1,600 feet. (See pl. 16.)

Structure.-The ore bodies are intersected by several faults that dip $30^{\circ}-40^{\circ} \mathrm{NW}$., thus intersecting the lenses at an oblique angle. The faults are of the reverse type and show a slip of 50 to 100 feet. One fault observed on the 500-foot level strikes east and dips $60^{\circ} \mathrm{S}$., and the fault plane shows striations parallel both to strike and dip. The faults cut the ore cleanly and show no mineralization.

The walls of the ore shoots are mostly well defined, but in some places they show transitions to silicified country rock. Locally on 
V. S. GEOLOGICAL BURVEY

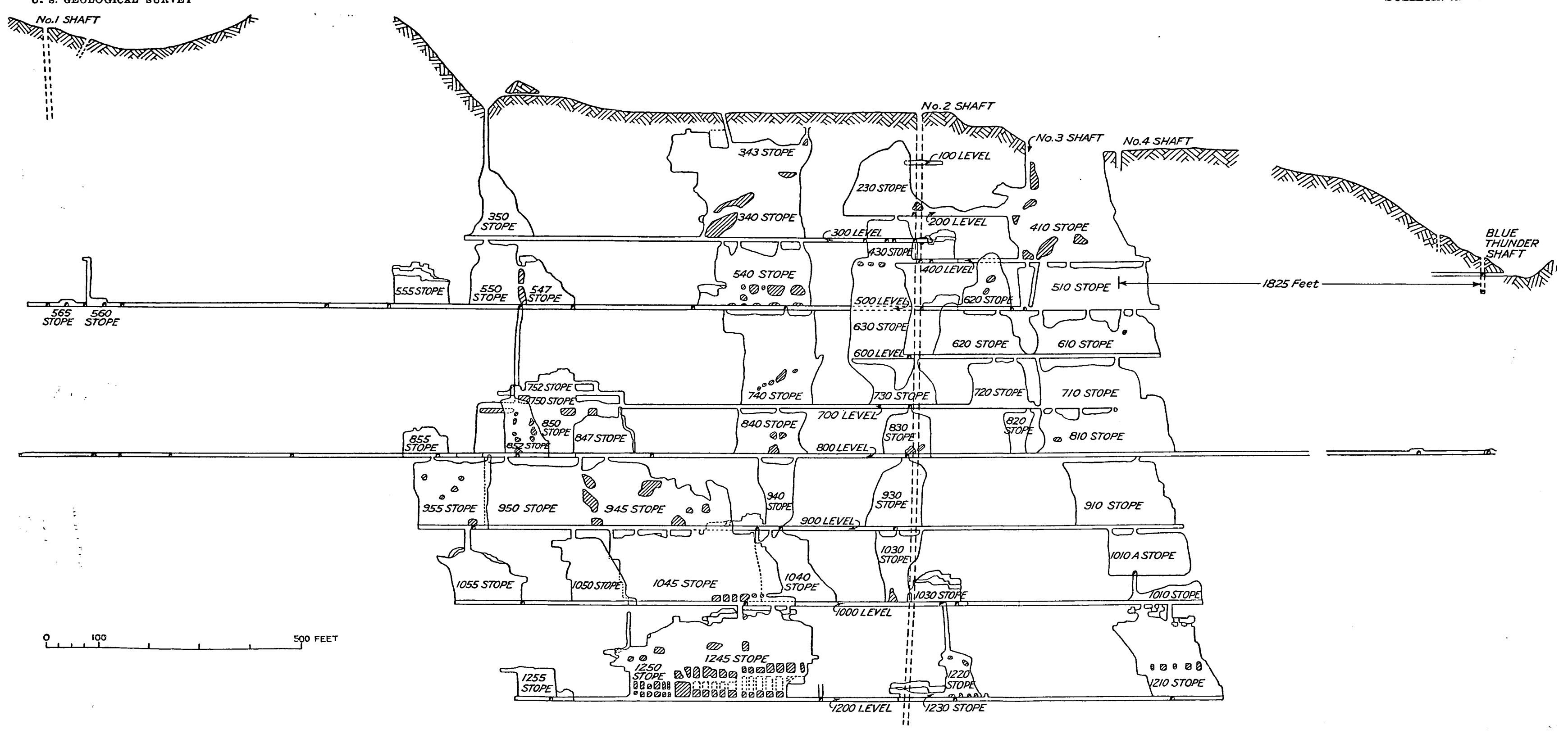

LONGITUDINAL SECTION OF BLUE BELL MINE 
such walls a groove structure is noted which conforms with the southward pitch of the shoot.

The ore.-The most common country rock is a chlorite-biotite schist. Within the silicified zone it may, however, be difficult to recognize the original character of the rock. The silicified material may contain sparse sulphides, but as a rule the ore is well defined. The ore is classified as heavy smelting ore and siliceous concentrating ore and averages 3 per cent in copper. The smelting ore contains also 1.5 ounces of silver and 0.05 ounce of gold to the ton; the siliceous ore averages 1 ounce of silver and 0.03 ounce of gold to the ton. As a rule the siliceous ore contains a little less gold and silver than the smelting ore.

The smelting ore is usually massive and rather fine-grained; it consists of pyrite intergrown with more or less chalcopyrite and containing spots of quartz and imperfectly replaced schist. A little calcite is universally present, but a fine-grained quartz mosaic replacing the schist is the principal gangue. The siliceous ore usually shows the schistose structure of the original rock and contains streaks of replacing sulphides. The minerals are pyrite and chalcopyrite, with very small amounts of arsenopyrite, sphalerite, and galena. No tetrahedrite was observed.

Polished sections show rude crystals and rounded grains of pyrite, fractured, cemented, and replaced by chalcopyrite and the other scant sulphides, among which dark sphalerite is the most abundant. (See pls. $9, B ; 17, B$.)

The ore shows less ankerite and more quartz than usual in the schist replacement deposits, but the succession of minerals is the same: quartz and carbonates are the oldest, followed by pyrite and later by chalcopyrite. The same dark-green iron-rich chlorite that was observed at Jerome appears here again in places.

Oxidation and water.-At the surface the ore is leached and rusty brown; there is no chalcocite zone proper, but a little chalcocite may be found in places down to the 1,200-foot level. On the 400-foot level a little oxidation is. observed, and 1,800 feet farther north on the 500-foot level the drift encountered a 2 -foot vein of chrysocolla and cuprite fully oxidized and containing no silver. The workings are rather warm, and the mine water is acidic and contains much copper. The original water level was probably at the 400 -foot level; the mine makes little water, say 150,000 gallons in 24 hours. 


\section{AGUA FRIA DISTRICT}

\section{GENERAI FEATURES}

At the end of the Tertiary epoch of lava flows Agua Fria River laid out a new course for itself over the desolate waste, and now instead of continuing in the open Bigbug Valley it runs in a moderately abrupt canyon, which trenches the Yavapai schist and is about 700 feet deep. The rocks exposed are thus mainly schists, though north of Stoddard there is an intrusive embayment of the large granite area of the Jerome quadrangle. Farther east lava flows cover the whole country.

The Yavapai schist here contains a number of quartzite lenses, and its composition is very complex, as described more fully in the section on the Binghampton mine. It contains several deposits of the schist replacement type, of which the most valuable are the Binghampton and the Stoddard. There has been a considerable production of copper ores, in part smelted, in part shipped, and in part concentrated.

\section{BINGHAMPTPON MINE}

Equipment and production.-The Arizona-Binghampton Mining Co. owns 10 claims north of the river about a mile above the Stoddard ranch. (See pls. 18, $B ; 19, A$.) The property is owned by W. Reynolds, of New York, and managed by George W. Johnson. The mine and mill are 300 feet above the creek, and.offices and residences are in the river bottom.

The mine has a modern electrical equipment. The developments include a 600 -foot shaft, 1,000 feet of adit, and about 4,000 feet of other workings in connection with these. A 3-compartment shaft has been sunk to a depth of about 1,000 feet. There is a 250-ton flotation mill on the property.

The mine was productive from August, 1916, to March, 1919, and also for some time in 1920. Unfavorable. working conditions necessitated its closing, but ore was shipped again in 1923. In all 8,000,000 pounds of copper was sold in the form of concentrates. The mine production up to 1922 was 150,000 tons of 3 per cent ore, carrying 2 ounces of silver to the ton. In addition to 25 per cent of copper, the concentrates yielded 33,197 ounces of silver and about 200 ounces of gold. The concentration is in the proportion of $7: 1$. The mine is said to contain a considerable amount of developed ore.

Geology.-The road from Mayer to the mine is 4 miles long and leads over gently sloping bare or brushy hills that afford good exposures. Most of the rock is a fissile grayish-green schist. The road is crossed by one well-defined brownish-gray quartzite reef, and 


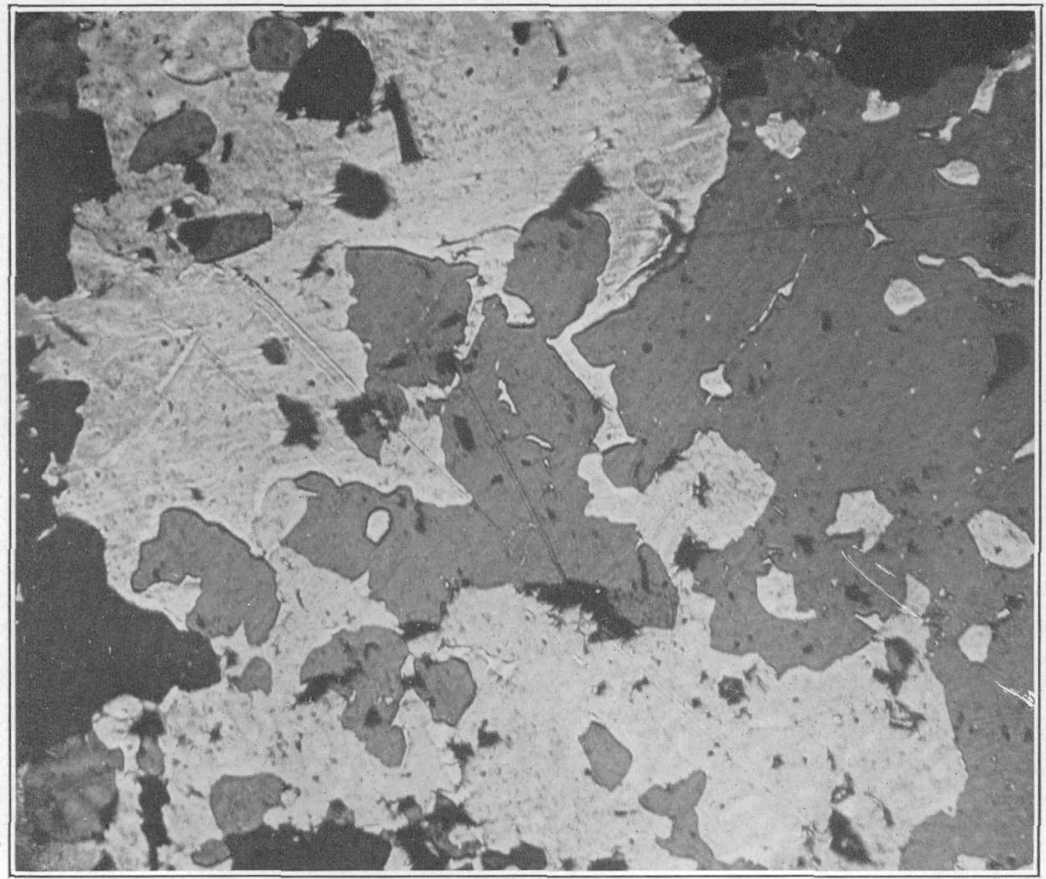

A. ORE FROM DE SOTO MINE

Chalcopyrite (light gray) and sphalerite (dark gray); the sphalerite replaced by veinlets of galena. Enlarged 130 diameters

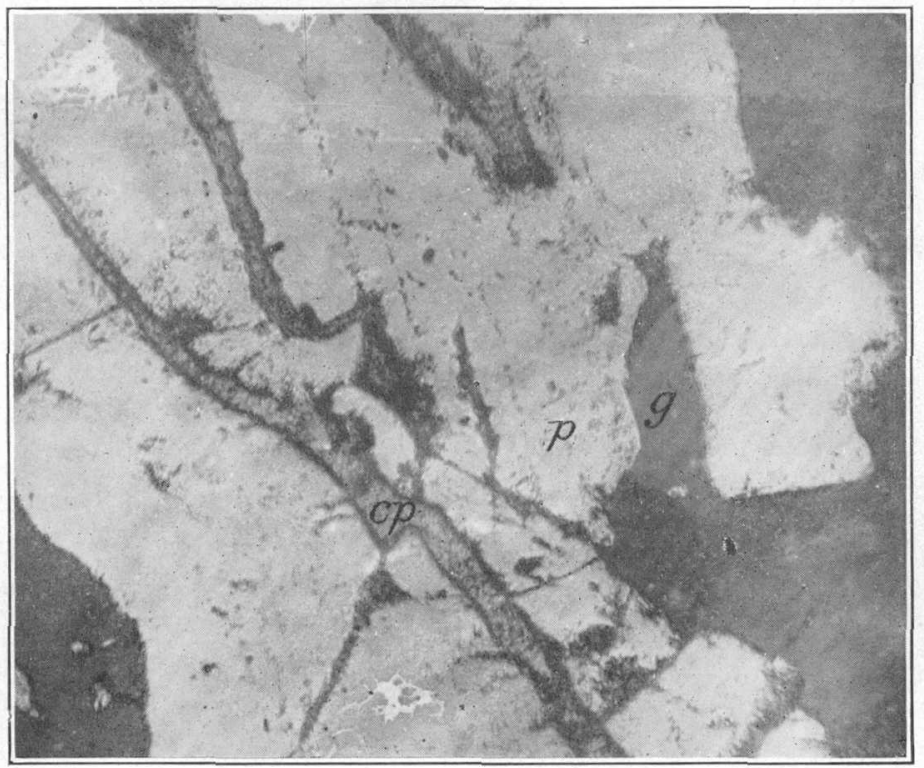

B. ORE FROM BLUE BELL MINE

Pyrite $(p)$ fractured, filled in, and replaced by chalcopyrite $(c p) . g$, Gangue. Enlarged 110 diameters 


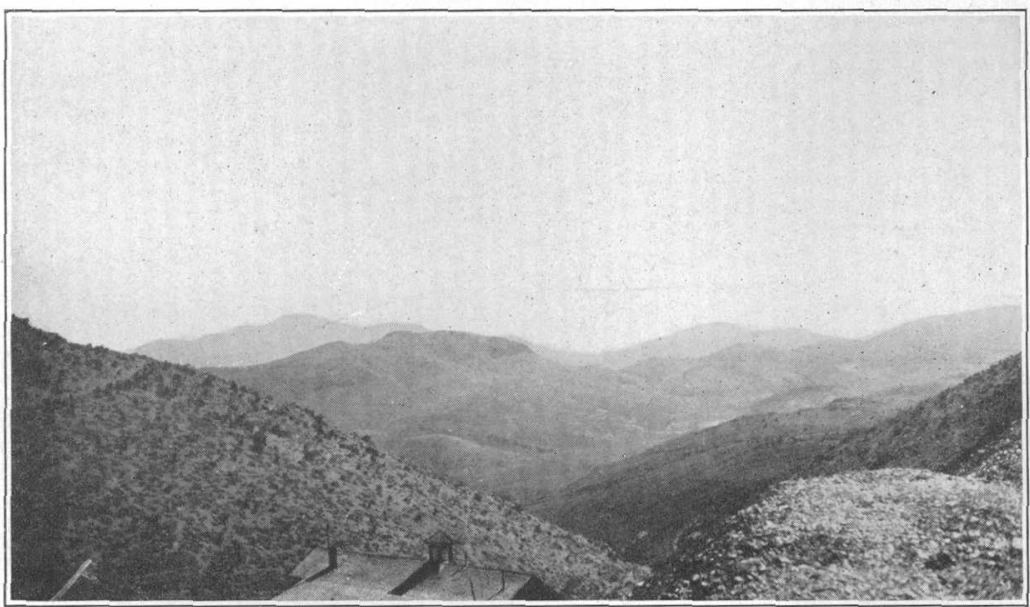

A. VIEW LOOKING SOUTH FROM BLUE BELL MINE ACROSS TURKEY CREEK TOWARD BRADSHAW MOUNTAINS

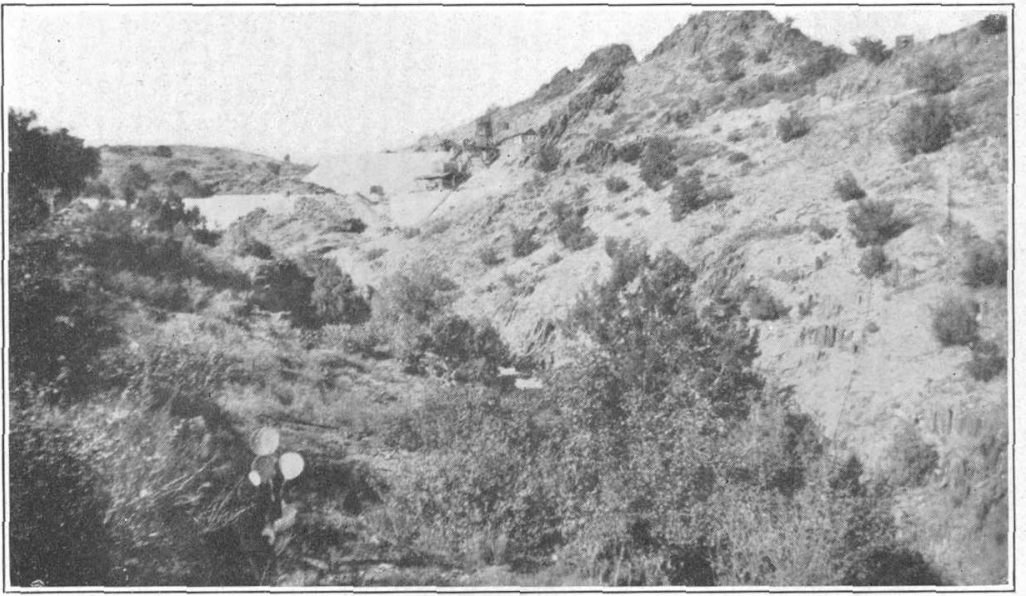

B. BINGHAMPTON MINE, AGUA FRIA DISTRICT

Outcrops of schist at left 


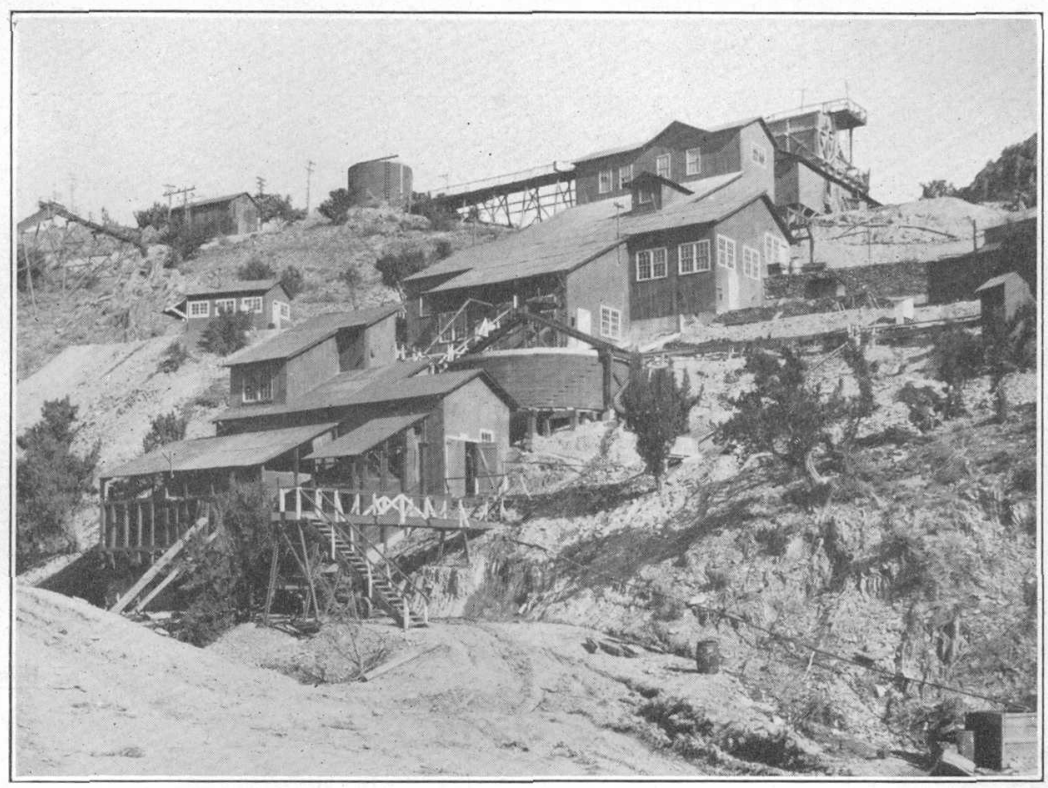

A. MILL OF ARIZONA-BINGHAMPTON CO., AGUA FRIA DISTRICT

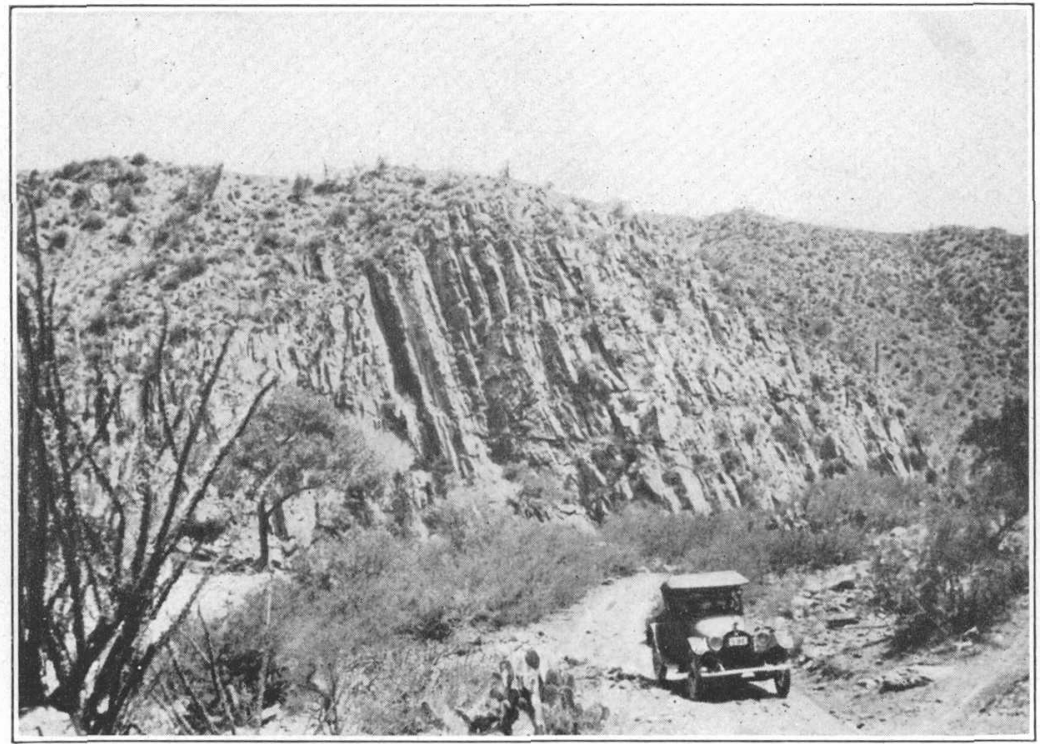

B. OUTCROPS OF YAVAPAI SCHIST IN BLACK CANYON 


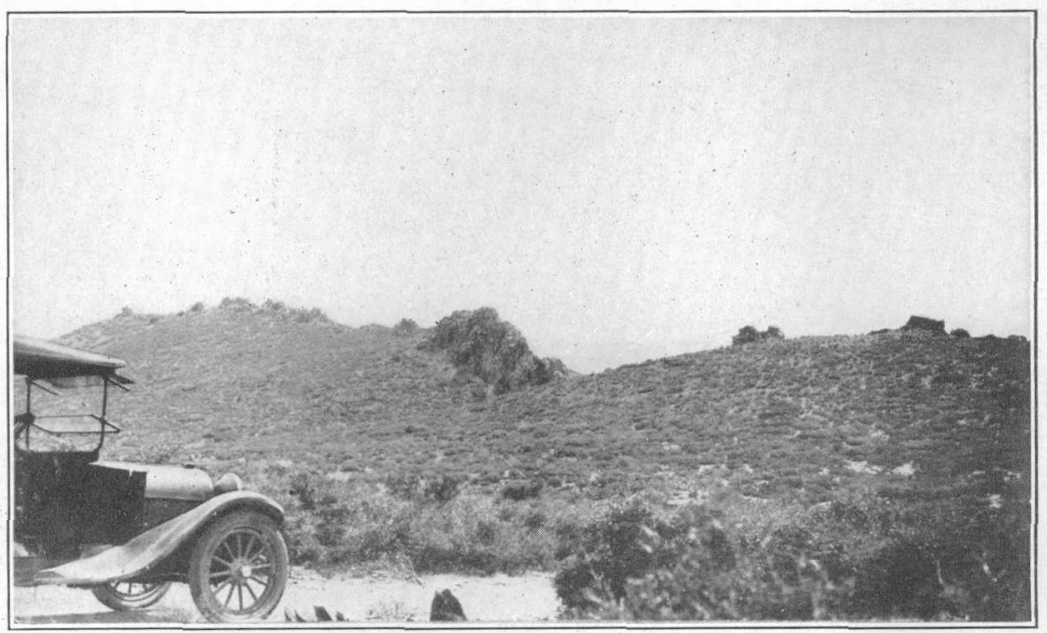

A, QUARTZITE OUTCROPS IN YAVAPAI SCHIST ON ROAD FROM MAYER TO STODDARD

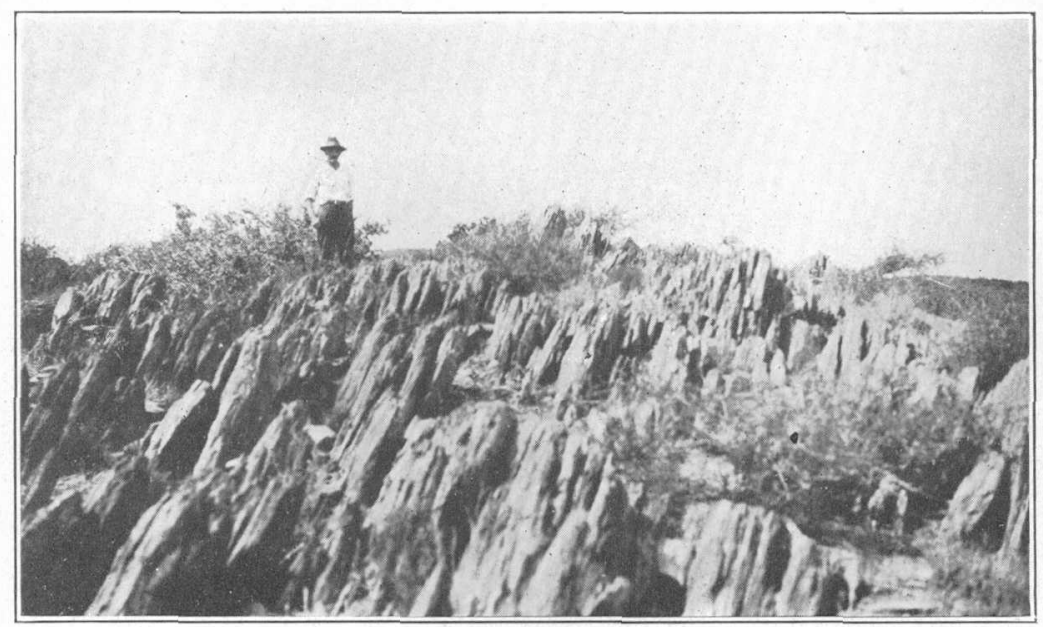

$B$. YAVAPAI SCHIST SHOWING "GRAVESTONE" OUTCROPS ON ROAD FROM MAYER TO STODDARD 
several others are seen in the distance. The quartzite is shattered in places and filled with white quartz. On both sides of the quartzite is a yellowish-white schistose quartz porphyry. (See pl. 20, A, B.) On the east side is also a mass of glassy quartz 40 feet wide with thin streaks and masses of felted black tourmaline. The quartzite and the quartz in places are said to contain a little gold.

In going up to the mine from Agua Fria River the rock first encountered is greenstone schist, in places looking very much like a sheeted volcanic agglomerate. Then follows fissile chloritic schist, appearing like clay slate. At the mill this slate contains a lens of crystalline limestone about 300 feet long and 15 feet wide. It incloses veinlets of quartz with fine bluish tourmaline. A little farther east, near the Copper Queen office, outcrops show schistose and in part fissile greenish quartz porphyry with phenocrysts of quartz. 'The dump of the Copper Queen mine shows mainly a greenstone schist, some specimens of which have small phenocrysts of quartz.

In the Binghampton mine the schist strikes N. $10^{\circ} \mathrm{W}$. and dips $70^{\circ} \mathrm{W}$. The schist is greenish and consists mainly of a pressed quartz porphyry; in places it can only be determined as chloritic schist.

The ore.-The ore occurs in three shoots, or lenses, in places over 10 feet wide. The 105 shoot is 100 feet long and extends down to the 600 -foot level. The 91 shoot is 50 feet long and at most 10 feet wide. The shoots have resulted from the replacement of schist by fine-grained quartz, not much crushed. The replaced material contains more or less pyrite but not so much as is usual in these deposits. There is much chalcopyrite, in part embedded in the schist but in considerable part in veinlets with dolomite and quartz. Tetrahedrite with some arsenic is unusually abundant, particularly in shoots 91 and 94 , and it seems particularly associated with a white dolomite containing very little iron. Other sulphides are rare. The ore contains much recrystallized chlorite, of which there are two varieties-one with faint double refraction, the other in larger aggregates and dull-yellow interference colors.

The succession of events was as follows: Chlorite was the earliest mineral and was followed by quartz and later by dolomite. The sulphides are in the main later, and the latest of these are sphalerite and the very rare galena. Arsenopyrite was observed in the ore from the adjoining Copper Queen. Much of the chlorite contains small grains of siderite.

Oxidation and water.-The water level stood 80 feet below the surface, and the oxidation had not penetrated any deeper. The chalcocite zone, if present, was very thin. A considerable area of rusty schist is exposed southwest of the mine, and the intention 
is to explore this rock as indicating a probable zone of sulphide impregnation.

COPPER QUEEN MINE

The Copper Queen mine adjoins the Binghampton on the east and comprises about 25 claims, owned by the Copper Queen Gold Mining Co. The mine is developed by two tunnels 593 and 600 feet long, a 500-foot inclined shaft, and about 8,000 feet of workings. It is stated that there are two ore bodies 7 to 12 feet wide on the 900-foot level, containing chalcopyrite and tetrahedrite with some gold and silver. A 100-ton flotation mill was recently erected. It was not operated in 1922. The ore and country rock are very similar to those of the Binghampton mine.

\section{STODDARD MINE}

The Stoddard mine is one of the earliest/ locations in Arizona. Much oxidized ore was mined in the early days and in part reduced in a smelter erected near Stoddard's ranch, on the Agua Fria. At present the mine is owned by C. M. Stoddard. The last work was done about 1919, but no ore was shipped then. The deposit crops out on a north spur of Copper Mountain at an altitude of 4,900 feet, or about 1,000 feet above the river. The developments consist of extensive upper workings, a lower tunnel about 700 feet long at an altitude of 4,470 feet, and a 300-foot winze below this level. The upper tunnel has an altitude of 4,690 feet. The ore body appears to have a tapering form, and it is almost wholly oxidized down to the tunnel level. The mine was closed in 1922, and the workings were not accessible. The production has been considerable, as some of the oxidized ore was rich.

The country rock consists of chloritic schist with lenses of quartzite; also, in places, cherty bands and some schistose quartz porphyry.

\section{OTHER PROPERTIES}

The Halfmoon property, 1 mile south of the Binghampton, at an altitude of 4,300 feet, or 460 feet above the river, has a vertical shaft 535 feet deep with drifts from the 500-foot level. Bunches of chalcopyrite, chalcocite, and tetrahedrite with some specularite were found. The water level stands at 300 feet below the collar, though the collar is 50 feet lower than that of the Binghampton shaft. The country rock is chloritic schist and some pressed quartz porphyry.

The Hall mine, from which some ore has been shipped, is half a mile southwest of the Stoddard. 
The Bigbug deposit, worked by Frank Thornton, is 2,000 feet due north of Copper Mountain and has been in operation since 1918. It is opened, by a shaft 235 feet deep in silicified chloritic schist. At a depth of 80 feet streaks of chalcopyrite with a little chalcocite were encountered.

On the summit of Copper Mountain is the claim of J. R. Robertson, of Mayer. Copper-Mountain is a reef of chloritic schist striking N. $5^{\circ}$ E. and dipping steeply east. Much quartz appears on the north end of the summit ridge. A cut 30 feet below the peak exposes abundant copper stains and some ore of good grade containing fresh, metallic chalcocite that has a deceiving primary appearance.

\section{TURKEY CREEK DISTRICT}

\section{GENERAL FEATURES}

The Turkey Creek mining district is an ill-defined area extending along the stream of the same name from the old town of Goodwin to a point near Turkey Creek station on the railroad line to Crown King. The rocks consist mainly of Yavapai schist, in part of sedimentary, in part of igneous origin. They are intruded by the Bradshaw granite of Brady Butte and by the monzonite porphyry of Battle Flat.

The Goodwin properties are best reached from Mayer by the new wagon road crossing Wolf and Pine Creeks. For the first few miles the schist appears to be of sedimentary origin with prominent reefs of quartzite. Most of the schist is fissile. Five miles from Mayer the schist becomes greenish and more massive. It strikes due north and dips $75^{\circ} \mathrm{E}$. This schist contains metacrysts of magnetite with quartz tails in a matrix of quartz mosaic with muscovite, chlorite, and epidote; there are also fairly abundant small prisms of tourmaline. In the vicinity there is much quartz with black tourmaline, probably developed along the contact of the Bradshaw granite of Brady Butte, not far to the south. From this point on to Wolf Creek and Pine Creek the dip changes to a steep westerly direction and the schist becomes markedly amphibolitic, with red soil. Some diorite porphyry is noted, and it is probable that the larger part of the Yavapai schist is here derived from basic igneous rocks.

At Pine Flat (altitude 5,500 feet), on Pine Creek, there are a few houses in pleasant surroundings, and the place is frequented as a summer resort. Here the amphibolite becomes more massive. 
Copper, lead, gold, and silver produced in Turkey Creek district, 1906-19:4

[Compiled by V. C. Heikes, U. S. Geological Survey]

\begin{tabular}{|c|c|c|c|c|c|c|}
\hline Year & $\begin{array}{l}\text { Crude ore } \\
\text { (tons) }\end{array}$ & $\begin{array}{l}\text { Copper } \\
\text { (pounds) }\end{array}$ & $\begin{array}{c}\text { Lead } \\
\text { (pounds) }\end{array}$ & $\begin{array}{c}\text { Gold (fine } \\
\text { ounces) }\end{array}$ & $\begin{array}{c}\text { Silver (fine } \\
\text { ounces) }\end{array}$ & Total value \\
\hline $\begin{array}{l}1906 \\
1907 \\
1908 \\
19090 \\
1911 \\
1912 \\
1914 \\
1915 \\
1916 \\
1917 \\
1918 \\
1919 \\
1921 \\
1922 \\
1923\end{array}$ & $\begin{array}{r}4 \\
51 \\
458 \\
134 \\
1 \\
38 \\
48 \\
23 \\
17 \\
64 \\
16 \\
46 \\
22 \\
52 \\
221 \\
100 \\
310 \\
470 \\
184\end{array}$ & $\begin{array}{r}247 \\
520 \\
137 \\
22 \\
1,074 \\
79 \\
292 \\
669 \\
970 \\
7,570 \\
35,249 \\
6,348\end{array}$ & $\begin{array}{r}2,600 \\
2,006 \\
4,342 \\
3,795 \\
1,55 \\
1,13 \\
2,628 \\
1,244 \\
577\end{array}$ & $\begin{array}{r}22.92 \\
13.29 \\
148.73 \\
111.74 \\
2.50 \\
14.79 \\
8.58 \\
16.98 \\
4.09 \\
43.33 \\
7.95 \\
34.55 \\
.41 \\
.51 \\
54.00 \\
29.38 \\
37.63 \\
172.83 \\
77.40\end{array}$ & $\begin{array}{r}163 \\
1,810 \\
778 \\
1,099 \\
343 \\
4,761 \\
5,124 \\
2,860 \\
2,189 \\
992 \\
1,662 \\
996 \\
2,769 \\
3,827 \\
9,196 \\
13,355 \\
18,315 \\
2,985 \\
1,560\end{array}$ & $\begin{array}{r}\$ 585 \\
1,657 \\
3,571 \\
3,136 \\
237 \\
3,001 \\
3,351 \\
2,079 \\
1,339 \\
1,527 \\
1,344 \\
1,878 \\
2,798 \\
4,774 \\
11,641 \\
15,019 \\
20,203 \\
11,203 \\
4,167\end{array}$ \\
\hline
\end{tabular}

\section{CUMBERLAND MINE}

The Cumberland mine is 1 mile north of Pine Flat and was last in operation about 1908. The owner is W. Woodburn, of Boone, Iowa. According to information from Mr. T. Roach, of Pine Flat, this is a gold quartz vein striking a little east of north and dipping west. The shaft is 350 feet deep and there are short drifts. The shoot on the north is said to have continued to the lowest workings; it contains ore of $\$ 40$ grade, which was treated in a 10 -stamp mill at Pine Flat. The gold is reported as free and visible in places. The water level was found at a depth of 90 feet.

It is probable that here, as in many other places, the conditions became unfavorable when the workings reached the sulphide ore below water level. There is said to be placer ground in the vicinity of the Cumberland mine.

\section{COPPER DEPOSIT}

Just west of Pine Creek is a small area of diorite porphyry which along the creek bed contains chalcopyrite disseminated in seams and spots. It resembles the Copper Basin occurrence, west of Prescott. On the ridge the rock is soft and decomposed and shows quartz seams and a little chalcocite.

\section{WAR EAGLE MINE}

About $2 \frac{1}{2}$ miles from Goodwin on the road toward Prescott, but still in the Turkey Creek drainage area, is the War Eagle, an old property of four claims, in which the oxidized ore has been worked from time to time. It is first mentioned in Raymond's report of 1874. In 1822 Erickson \& Grant were leasing from the owner, Mr. 
McMaster, of Gallup, N. Mex., and were prospecting the vein south of the old workings. Last year, it is reported, ore to the value of $\$ 20,000$ was extracted from the William and Mary claim. Undoubtedly the property has had a considerable production.

The old shaft from which work was done 30 or 40 years ago is 300 feet deep and the stopes are principally within 100 feet of the surface.

The vein, which strikes north and dips steeply west, is contained in mixed rock looking like the Crooks complex but made up chiefly of fine-grained granite. No porphyry dikes were observed. The vein is narrow, at most 2 feet wide, and contains drusy comb quartz with galena, sphalerite, and tetrahedrite, also some chalcopyrite. The oxidized ore is reported rich in chlorides.

\section{GOLD NOTE GROUP}

The Gold Note property is about 1 mile north of the War Eagle, in the Turkey Creek drainage basin. It was not visited, but the data given below were extracted from an apparently reliable report. The claims were sold in the early eighties to the Turkey Creek Gold \& Silver Co. for $\$ 75,000$. Later on, after much money had been spent, the property was abandoned. It is now owned by G. R. Guynne. The vein, which is said to be traceable for 3,000 feet, is developed by a shaft 270 feet deep and an adit 100 feet below the collar. The ore contains silver, gold, and lead, with siderite gangue. There are two stopes, but no record was found of the shipments except 12 tons that averaged 52 ounces of silver and $\$ 2.40$ in gold to the ton, with 72 per cent of lead. The ore is thus somewhat different from that in the War Eagle. North of the Guynne place is the Dolphin prospect, which is provided with an old gold and silver mill.

\section{GOODWIN PROPERTIES}

Along the road from the War Eagle to Goodwin the rocks look like the Crooks complex. Aplite, granite, and schistose diorite are mixed, but schistose amphibolite prevails and continues to and beyond Goodwin. No porphyry was observed. The properties extend from the vicinity of Goodwin for a mile or more up toward the slopes of Bigbug Mesa in a northerly direction.

The Goodwin claim has yielded considerable ore. The Roach claim, next toward the north, has produced about $\$ 60,000$ gross, according to Mr. Tom Roach, an old-time miner of the district. $\mathrm{He}$ also states that he has sent out a carload averaging $\$ 600$ a ton. The claims north of the Roach are owned by R. Burmister, of Pres- 
cott. Oxidized ore from these claims, said to be of high grade, was trucked to the Humboldt smelter by lessees in 1922 .

Of the primary ore in this long vein not much is seen. It is probably composed of quartz, tetrahedrite, and galena. The oxidized ore yields chlorides and native silver. Whether the sulphide ore in depth will be of shipping grade is uncertain:

In the same vicinity north of Goodwin is also the Bully-Bueno silver mine, an old property mentioned in 1883 . There was an old mill, now razed, built for this property below Goodwin on Turkey Creek.

\section{MORGAN MINE}

The old Morgan mine is on Pine Creek 1 mile above its confluence with Turkey Creek. At the time I visited the district I was not aware of the existence of this property, and the following notes are obtained from a report by Mr. W. W. Lytzen, mining engineer of the Henrietta mine. The Morgan mine is also one of the old-time producers and is said to have shipped ore to the value of $\$ 50,000$ or $\$ 100,000$ about 20 or 30 years ago. The vein strikes N. $20^{\circ}$ E., dips $53^{\circ} \mathrm{W}$., and is developed by a 125 -foot incline. On the surface it has been worked for a distance of 2,000 feet. Work has lately been resumed. The ore carries vuggy quartz and ruby silver, with some galena and sphalerite but practically no pyrite. The country rock is schist, and the vein follows a light-colored dike 600 feet wide. It almost adjoins the granite area of Brady Butte.

A short distance to the southeast in the granite is the Franklin group of two claims, located on a northeastward-striking fissure vein dipping northwest, which carries lead, zinc, and silver. The vein is said to be 5 to 7 feet wide and is developed by a 100 -foot shaft and a 350-foot adit, 400 feet below the collar of the shaft. A sample of the 18-inch vein yielded 41 ounces of silver to the ton.

Both groups are owned by Charles Bate and J. E. O'Brien, of Mayer.

\section{BLACK CANYON DISTRICT}

\section{TOPOGRAPHY AND GEOLOGY}

The east side of the great granite mass of the Bradshaw Mountains is drained by the stream in Black Canyon. This stream is formed by the confluence of Poland and Turkey Creeks; farther south it receives Bumblebee Creek from the east, and near Goddards the Black Canyon debouches in Agua Fria River. The main drainage is in general north to south and is determined by the junction of the lava flows of the Agua Fria with the slopes of the Bradshaw Mountains. The altitude ranges from 4,000 to 2,000 feet. The upper course of the canyon is deeply incised into the granite, 
but over the greater part of its course the cut is not much more than 1,000 feet.

The mining district of Black Canyon is not very well defined, but in general includes the valley extending for 25 miles from Turkey Creek station to Goddards.

The geology is simple in its broader features. There are two large areas of pre-Cambrian granite-the Bradshaw Mountains on the west and the equally large area partly. covered by lava on the east. Between the two and extending due north is a strip 2 miles wide of Yavapai schist, mostly of sedimentary origin. (See pl. 19, $B$.) On the east side of this schist adjoins a narrow but very persistent strip or perhaps, rather, dike of diorite, a hard green rock weathering red, from 2,000 to 5,000 feet wide. Jaggar and Palache regard it as a contact phase of the granite.

The big depression on the east is now filled by lava, the level top flows of which attain an altitude of about 4,000 feet. Throughout its course the Agua Fria trenches these flows, exposing a narrow strip of granite in the bottom. Several strong dikes of rhyolite porphyry appear near Turkey Creek station on the Prescott-Crown King branch road.

The mineral deposits consist of (1) a series of pyritic lenses in the schist, not continuous but occurring at short intervals; $(2)$ preCambrian magnetite deposits in schist; (3) pre-Cambrian quartz veins, most of which appear near Bumblebee and Bland Hill; (4) many flat veins of the younger type, apparently connected with dikes of rhyolite porphyry; (5) placer deposits along the Black Canyon. The flat veins, some of which have had a considerable production, carry either silver or gold or both in quartz gangue. Little work is done at the present time.

Copper, lead, gold, and silver produced in Blacle Canyon district, 1904-1924

[Compiled by V. C. Heikes, U. S. Geological Survey]

\begin{tabular}{|c|c|c|c|c|c|c|}
\hline Year & $\begin{array}{l}\text { Crude ore } \\
\text { (tons) }\end{array}$ & $\begin{array}{l}\text { Copper } \\
\text { (pounds) }\end{array}$ & $\begin{array}{c}\text { Lead } \\
\text { (pounds) }\end{array}$ & $\begin{array}{c}\text { Gold (fine } \\
\text { ounces) }\end{array}$ & $\begin{array}{c}\text { Silver (fine } \\
\text { ounces) }\end{array}$ & Total value \\
\hline $\begin{array}{l}1904 \\
1905 \\
1906 \\
1908 \\
1909 \\
1911 \\
1012 \\
1913 \\
1914 \\
1915 \\
19178 \\
1919 \\
19201 \\
1922 \\
1923 \\
1924\end{array}$ & $\begin{array}{r}667 \\
4,016 \\
2,157 \\
1,548 \\
268 \\
26 \\
69 \\
191 \\
224 \\
61 \\
27 \\
2 \\
10 \\
94 \\
142 \\
109 \\
93 \\
129 \\
71 \\
161\end{array}$ & $\begin{array}{r}29 \\
61 \\
319 \\
1,092 \\
918 \\
609 \\
264 \\
139 \\
383 \\
2,936 \\
274\end{array}$ & $\begin{array}{r}\mid 6,288 \\
3,120 \\
12,808 \\
33,667 \\
25,258 \\
8,258 \\
10,332 \\
3,979 \\
12,273 \\
\\
\hdashline\end{array}$ & $\begin{array}{r}506.00 \\
1,000.00 \\
1,108.19 \\
162.05 \\
188.59 \\
1.70 \\
84.55 \\
126.07 \\
44.72 \\
8.88 \\
20.16 \\
5.00 \\
3.29 \\
16.09 \\
6.00 \\
2.20 \\
34.00 \\
54.65 \\
42.53 \\
26.62\end{array}$ & $\begin{array}{r}2 \\
162 \\
540 \\
112 \\
463 \\
2 \\
2,930 \\
7,448 \\
11,096 \\
5,700 \\
870 \\
2 \\
91 \\
7,583 \\
5,496 \\
5,544 \\
9,074 \\
4,619 \\
937 \\
3,943\end{array}$ & $\begin{array}{r}\$ 10,461 \\
20,770 \\
23,275 \\
3,430 \\
4,407 \\
170 \\
3,001 \\
8,108 \\
8,065 \\
3,990 \\
898 \\
104 \\
420 \\
8,650 \\
6,603 \\
6,138 \\
10,347 \\
5,801 \\
2,079 \\
3,231\end{array}$ \\
\hline
\end{tabular}




\section{RAINBOW LODE}

The Rainbow deposit, the property of J. P. Cleator, of Turkey Creek station, lies in fine-grained biotite schist $1 \frac{1}{2}$ miles northeast of the station, on the west side of Townsend Butte. It is a lenticular mass of pyrite, pyrrhotite, and a little chalcopyrite in a gangue of epidote, calcite, magnetite, and a little brown mica; the mass is about 200 feet wide. A shaft 100 feet deep has been sunk on a stringer east of the main deposit. The ore is of low grade. Undoubtedly this ore is of contact-metamorphic origin, and represents alteration of a limestone lens by emanations from the Bradshaw granite or perhaps an underlying mass of that rock not visible on the surface.

Near 'Turkey Creek station and in Crazy Basin, where the granite breaks across the strike of the schist, the contact metamorphism is very strong. Near the contact the schist is coarse, with silvery luster, and contains many irregular quartz veins with coarse tourmaline. There are many quartzite ledges which here form a part of the series; also, lenses of magnetite (pp. 35-36) probably formed in part by contact-metamorphic processes. Farther north, up toward the Blue Bell mine, the schist is amphibolitic and forms gravestone-like outcrops.

\section{PYRITIC DEPOSITS EAST OF TURKEY CREEK STATION}

About 2 miles east of Turkey Creek station the schist contains much disseminated pyrite and chalcopyrite. Many claims in this vicinity are owned by S. M. Parker. One shaft just north of the road on the Great Republic claim is 50 feet deep and is sunk on a rusty outcrop 15 feet wide. In the bottom partly oxidized pyrite was found. Half a mile south of this place is a group of many claims on similar material; a shaft 700 feet was sunk on it but, it is claimed, being vertical diverged from the pyritic schist, and no crosscutting was done. On the same belt are the Theising claims, which were not visited.

\section{HOWARD . COPPER CO.}

The property of the Howard Copper Co., of which Ralph Roseberry is in charge, is in Black Canyon 1 mile west of Bland Hill and 16 miles south-southeast of Turkey Creek station. (See pl. 21, A.) An outcrop of chloritic schist rises 70 feet above the river bottom. The strike is nearly north. Near the top are several streaks that are strongly copper stained. Below this bluff a tunnel 560 feet long has been driven in a southerly direction. The second and fourth crosscuts open a lens of ore 5 feet wide, which, according to Mr. Rose- 
berry, yields 9.5 per cent of copper, with $\$ 2.80$ in gold, and 1 ounce of silver to the ton. The mineralized material is about 20 feet wide and is said to assay 1 to 2 per cent in copper. A shaft is now being sunk from the top of the bank about 100 feet above the river. In 1924 favorable reports were published in the press.

The copper occurs as narrow streaks of chalcopyrite, with some pyrite and ankerite, in a light-green fissile chloritic schist. Under the microscope the ore proves to be made up of light-green chlorite flakes distributed in streaks in a quartz mosaic. The sections contain some rutile and a few prisms of tourmaline, evidently later than the dynamic metamorphism. Probably it was introduced by the emanations of the granite. None of the schists are beyond doubt of sedimentary origin. A mile below the camp there is some schistose green quartz porphyry.

\section{KAY COPPER CORPORATION}

The property of the Kay Copper Corporation, of Phoenix, is about a mile south of Canyon, on Agua Fria River, near the mouth of Black Canyon Creek. It is considerably south of the Black Canyon district proper. The company owns many claims and has developed this property by an older incline 600 feet deep, with crosscuts and diamond-drill holes, on the west side of the river, and a new vertical shaft, now 1,500 feet deep, on the east side a little farther down. In the report for 1925 it is stated that the developments comprise 15,045 feet of tunnels and shafts and 17,906 feet of diamond-drill holes. The altitude is about 1,850 feet. A heavy flow of water was struck in the new shaft on the 850 -foot crosscut to the ore body.

A large body of commercial ore is said to have been disclosed, stated in Weed's Mines Handbook for 1921 as 296,000 tons. The property was temporarily closed when visited in 1922. The ore is said to average $11 / 2$ to 3 per cent in copper and $\$ 2.50$ to the ton in gold and silver. Late reports, in Mineral Resources for 1923 (p. 545), claim an ore reserve of 71,000 tons with a large amount of probable ore.

The property south of the Kay is held by the Harris Copper Co.

The country rock is a more or less fissile chloritic schist striking N. $20^{\circ} \mathrm{E}$. and dipping $70^{\circ} \mathrm{WNW}$. Under the microscope the schist proves to be made up of a fine-grained quartz mosaic with much foliated chlorite and some rutile. It is in part replaced by ankerite, in part traversed by veinlets of pyrite and chalcopyrite. Tetrahedrite or tennantite is abundant in some specimens. The veinlets also contain some quartz. Some schist specimens are densely impregnated with pyrite. 
The Yavapai schist in places contains so much magnetite that it may be properly called magnetite schist. Jaggar and Palache ${ }^{50}$ described magnetite schist from Blind Indian Creek, 2 miles southwest of Bueno, where the magnetite forms about 50 per cent of a quartzitic schist, with more or less garnet and epidote. Another locality is $1 \frac{1}{2}$ miles north of White's ranch, near Minnehaha.

In the Black Canyon district two very remarkable occurrences of magnetite schist were found, but neither will probably ever bə of economic importance. One of the new localities is on the east side of Townsend Butte, 1 mile east of Turkey Creek station. Some magnetite is also found on the west side of the butte, below the Rainbow deposit (p. 154). A heavy lens of quartzite at the east foot of the butte is adjoined by a belt 200 feet wide in which the schists are extremely rich in magnetite and hematite. The other locality is 1 mile below the Howard Copper Co.'s camp in Black Canyon. Here the magnetite is accompanied by red jasper, and the banded and contorted material looks very much like some of the Lake Superior iron ores.

\section{PRE-CAMBRIAN QUARTZ VEINS}

Within the Black Canyon district there are several quartz veins belonging to the older (pre-Cambrian) series. One of these at Turkey Creek station is in the Yavapai schist and is the property of J. P. Cleator. A 50-foot shaft is the only opening on this vein. The strike is northwest, the dip $70^{\circ} \mathrm{SE}$. It is a 2 -foot vein of coarse glassy quartz with a small amount of sulphides and is said to carry free gold. Other similar veins are found near by, and these deposits have undoubtedly yielded most of the gold found in shallow placers on the flat.

Similar veins are found in granite on Bland Hill and in schist or diorite at the Nigger Brown and Blanchiana properties, 3 and 4 mil:s south of Bumblebee. At the Blanchiana some high-grade gold ore has been extracted and treated in arrastres. The Nigger Brown (Valencienne?) mine is developed by a shaft, and ore bins have been erected, indicating an intention to ship.

At $4 \frac{1}{2}$ miles south of Bumblebee, 2 miles south of the Nigger Brown mine and 1 mile east of the Blanchiana, is the Gillespie mine, formerly owned by Mr. Mayer. From this property $\$ 80,000$ in gold is said to have been extracted in early days.

so U. S. Geol. Survey Geol. Atlas, Bradshaw Mountains folio (No. 126), p. 11, 1905. 


\section{RICHINBAR MINE}

Though not in the Black Canyon district, the Richinbar mine, on Agua Fria River, is appropriately described here. It seems to be one of the best of the pre-Cambrian veins; and much work has been done on it. The mine is at an altitude of 3,500 feet on the brink of the Agua Fria Canyon, 4 miles east of Bumblebee. The vein crops out in granite at the edge of a basaltic mesa, and from the property a beautiful view is obtained across the abrupt trench of the river, 1,000 feet deep, far to the east across similar basaltic flows. At present the mine is idle. The owners are Merriweather \& Brodenax, of Kansas City, Mo. Some of the following information was obtained from Mr. E. M. Walker, of Mayer, who worked in the mine.

There are two parallel veins at the Richinbar, striking north and dipping steeply to the west. The shaft is 480 feet deep and vertical; there are no deep tunnels from the canyon, but the vein is said to be traceable southward across the canyon. All levels from the shaft are extended northward. At its best in the stopes the vein is 30 feet wide; this is said to be at a depth of 140 feet. A 20 -stamp mill provides for the reduction of the ore. This mine has been worked by three different companies. Five years ago it was unwatered and retimbered. No information is available as to the total production, but it is evident that much ore has been milled. It is reported that from 1905 to 1908 about 8,000 tons of ore containing about $\$ 6$ in gold to the ton and a little silver was mined.

The ore occurs in irregular vertical shoots and consists of coarse massive quartz with some chalcopyrite, pyrite, galena, and sphalerite. A thin section shows that the large quartz grains in the ore are crushed; dark-green fine-grained aggregates associated with the sulphides prove to consist of minute prisms of blue, brown, or colorless tourmaline.

The gold is said to be free in the oxidized zone; below this zone the ore is not so easily reduced.

\section{PLACERS}

Placers have been worked at several places in Black Canyon, particularly below the Howard Copper Co.'s property. A few years ago a Portuguese is said to have taken out $\$ 20,000$ near the old stone cabin 1 mile below Howard. There are also small placer deposits near Turkey Creek station, and every year more or less dry washing is done by Mexicans in this locality. 


\section{"GOLD BELT" NEAR TURKEY CREEK STATION}

About 2 miles east of Turkey Creek station, in the flat at an altitude of 3,100 feet, are numerous openings on several very flat quartz veins. The country rock is schist, and the veins cut squarely across the schistosity. These veins are said to extend up to Dripping Spring on the north. They are as much as 6 inches wide and are formed of quartz filling with excellent comb structure and a little pyrite and galena. Some of this ore is said to contain $\$ 100$ in gold to the ton. Much mining has been done on a small scale, and a considerable amount of ore has been shipped. One of these deposits is known as the Hidden Treasure. The veins observed dipped $10^{\circ}-30^{\circ}$ E. The gold does not appear to be free except in the oxjdized portions.

\section{SILVER CORD VEIN}

About a mile southeast of Turkey Creek station is the Silver Cord vein, said to be traceable through six claims. It dips south or southeast at an angle of less than $20^{\circ}$. This vein contains both silver and gold, together with some pyrite, galena, and chalcopyrite. The deposit was operated for several years, and 20 or 30 carloads of shipping ore is said to have been produced. In 1912, it is reported, 224 tons was shipped containing $\$ 40.67$ a ton in gold, silver, copper, and lead. Among the properties on the Silver Cord vein is the American Flag, or the Old Brooks mine. Mr. Cleator, of Turkey Creek station, states that he shipped about 12 carloads from this property. The first-class ore contained $\$ 75$ to the ton; the second-class ore $\$ 18$ or more.

\section{THUNDERBOLT MINE}

The Thunderbolt is a flat vein in amphibolite schist, $31 / 2$ miles southeast of Turkey Creek station, on the east side of Black Canyon, close to the wagon road to the property of the Howard Copper Co. Once the property of D. J. Thompson, an old-time miner of the district, it is now owned by the Black Canyon Mining Co., of Kansas City, Mo. It is opened by a tunnel 1,800 feet long with its portal on the Silver Zone property; the tunnel connects with a shaft on the hill 240 feet above. There is a 20 -ton flotation mill on the property. Small shipments have been made of high-grade silver ore with at most $\$ 1$ in gold to the ton; it is said that they amounted to 150 tons in all. A run of 600 tons was made, but mine and mill were closed in 1922. Small shipments have also been made from the Silver Zone. 
The vein, which is said to be traceable for a mile across the schist, dips N. $20^{\circ} \mathrm{W}$ : and is several feet in maximum width. The ore has a quartz gangue with some ankerite, together with galena and sphalerite. The high-grade ore contains proustite (ruby silver), and the oxidized ore yielded chloride and native silver. Ruby silver appears to have been the principal rich ore mineral. A considerable tonnage of milling ore is said to be blocked out.

HOWARD SII,VER CO.

A little farther south along the road from the Thunderbolt, about 1 mile from the mine of the Howard Copper Co., is the Howard Silver Co.'s property. The deposit here is a flat vein in amphibolite, which strikes N. $50^{\circ} \mathrm{W}$. and dips $25^{\circ}$ NE. An incline 200 feet long opens the deposit, and drifts have been extended for 200 feet west. No work was being done in 1922. The vein is about 2 feet wide and consists of quartz filling with fine comb structure and much galena and light-brown sphalerite deposited on the quartz comb. It is said that about 1 carload of silver ore has been shipped, and some ore was treated in the Silver Zone mill. A flotation mill was erected on the property in 1924.

A parallel vein, the Iron Age, lies a quarter of a mile to the southeast. Another vein, the D. J. H., belonging to the same company, is a short distance to the west in granite. This is developed by a tunnel about 300 feet long; and an incline sloping $35^{\circ}$. E. descends 190 feet from the tunnel level. The deposit carries ore of the same kind as the Howard vein, and according to information received from Mr. W. W. Lytzen shipments have been made from two narrow ore shoots pitching northeast. The vein strikes N. $25^{\circ}$ W. and dips north-northeast.

\section{FRENCH LILY MINE}

The French Lily property, owned by Grove Brothers, of Mayer, is another of these peculiar flat veins. It was not visited but appears to be 2 miles southwest of Turkey Creek station, probably in granite. This vein, which is about 2 feet wide, dips $30^{\circ} \mathrm{N}$. and is developed by an incline 190 feet long, with 250 feet of drifts on the second level. The best ore is said to contain 50 per cent of zinc and $11 / 2$ ounces of gold to the ton. One carload has been shipped, and it is claimed that 800 tons has been developed. The ore shows a filled quartz vein with comb structure. A considerable amount of ore was shipped from this property in 1923. In Mineral Resources for 1923 this ore is credited to the Turkey district. 


\section{PECK DISTRICT}

The Peck mining district occupies a few square miles in the drainage areas of Peck Canyon and Bear Creek, both of which debouch into Turkey Creek. The altitude ranges from 5,000 to 6,000 feet. It is a region of high, rugged ridges, well wooded in the higher parts, and sharply incised canyons. Toward the east the country drops off to the deep depression of Crazy Basin, whose altitude is about 4,000 feet. The branch road from Mayer to Crown King runs up Crazy Basin, and the district is served by the Peck siding. A station on this railroad and a good wagon road connect the siding with the Peck mine. An old road, now in disuse, leads into the district from Crown King.

The principal formation in the district is the Yavapai schist, which here forms a belt about 2 miles wide between areas of Bradshaw granite on the east and west. The schist is partly of sedimentary and partly of igneous origin but contains also one or two large dikes of light-colored porphyry, injected into the schist parallel to the strike, and at least one prominent ledge of quartzite. The ore deposits are largely silver-bearing veins, but the district includes one disseminated copper deposit of importance.

Copper, gold, silver, and lead produced in Peck district, 1904-1924

[Compiled by V. C. Heikes, U. S. Geological Survey]

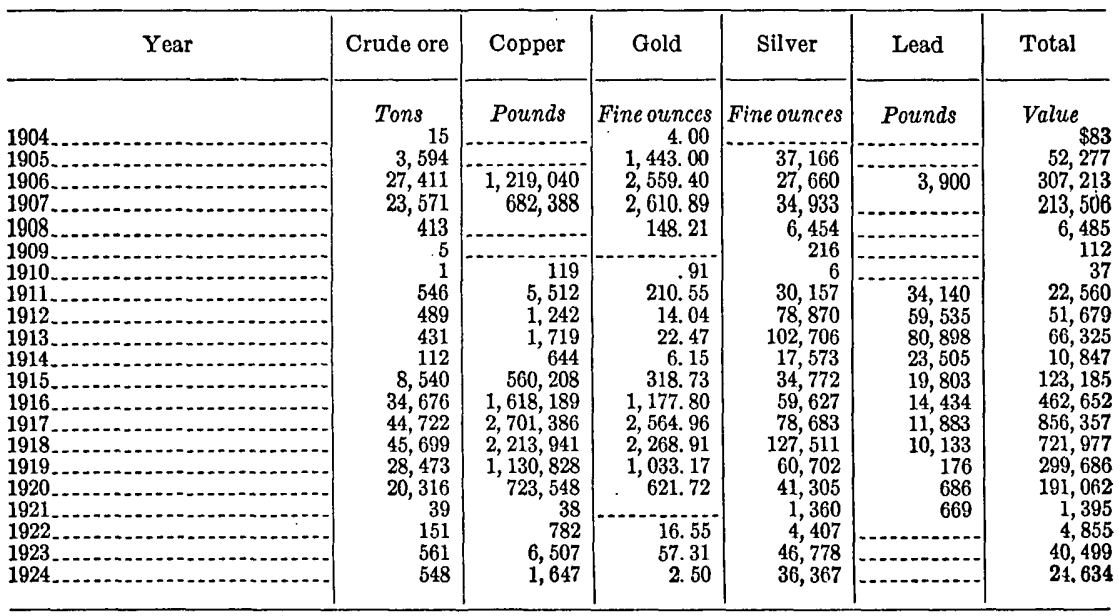

PROPERTIES SOUTH OF THE PECK MINE

From the heights of Crown King the traveler descends along the dilapidated wagon road by the Lincoln mine over schistose Bradshaw granite, with a wide outlook across the deep depression toward the east. Below the Lincoln mine are the Blue Bird and Gold King properties, which are noted in the section on the Pine Grove district. The trail continues to the Peck mine over clay slate and amphibolite. 
The Peck is one of the old-time silver bonanzas and at present is owned by O. Tawney, of the Swastika mine, near by. The Peck deposit, according to Raymond's reports, was discovered June 16, 1875 , by E. G. Peck. Rich ore was found from the start. In the early days 10 tons was sold at Prescott for $\$ 13,000$, which was considered much below the actual value.

In the Mint report of 1883 the mine is mentioned as highly productive. At that time the levels aggregated 1,400 feet in length, and a shaft 400 feet deep was sunk. There was a 10-stamp mill on the property. About $\$ 1,000,000$ to $\$ 1,500,000$ in silver is the reported production between 1875 and 1885 . Since then there has been some intermittent work by lessees, and in 1922 steps were taken to reopen the property.

The country rock is quartzite, a lens in the Yavapai schist, with some amphibolite schist. There are three veins, parallel and following the strike and dip of the schist; that is, N. $25^{\circ} \mathbb{E}$. and $75^{\circ} \mathrm{W}$. A porphyry dike 50 feet wide is said to have been cut between the Peck and Occident veins. For the most part the ore appears to have made in the quartzite. The outcrops of the vein appear in a bold quartzite bluff in the creek, rising about 50 feet above the stream grade. The tunnels following the veins start from creek level, and there are two shafts, at the north and south ends of the property. The northerly shaft, now in operation, is 387 feet deep, and the collar is 50 feet above the creek.

The veins are in places several feet wide. The ore consists mostly of dark-brown quartzite partly replaced by limonite. From the tunnel at creek level good specimens were obtained coated with green bromyrite, also containing a little iodine. A specimen rich in native silver was obtained from Mr. Tawney. The principal ore mineral was evidently bromyrite. The principal gangue minerals are siderite or ankerite, now almost wholly converted to limonite. Barite is also present.

According to Mr. Tawney much rich oxidized ore was taken out from the shaft below the water level, though little of value was found in the lower levels. A specimen of sulphide ore from the 300 -foot level is said to have contained 19.75 per cent of copper, 24 per cent of antimony, and 3,800 ounces of silver to the ton. Some zinc is also reported from the lower levels.

The extraordinary concentration of value in the oxidized zone of this vein is certainly remarkable, and it would seem possible that further exploration might reveal ore, though probably of lower grade in depth. No maps of the old workings are available. 


\section{SWASTIKA MINE}

A mile east of the Peck along the road to Peck siding are the Black Warrior and Silver Prince veins, now owned by Frank W. Giroux, of Mayer, under the name of the Swastika Silver \& Copper Co.

The Silver Prince is mentioned in Raymond's report of 1877 with the statement that the cost of packing the ore to Prescott was $\$ 50$ a ton. The Mint report for 1883 mentions both veins, stating that the Black Warrior was 2 to 3 feet wide, that $\$ 40,000$ in silver had been extracted so far, and that 8 tons a day was milled in a 4-stamp mill for a yield of 113 ounces of silver to the ton. About 1885 the mine was considered exhausted, and it was idle until reopened by F. W. Woods in 1910. From 1910 to 1915 the mine produced 600,000 ounces of silver. The total production is stated to be about $1,000,000$ ounces. Since 1915 the mine has been in intermittent operation. Mr. Woods states that from 1875 to 1908 the Silver Prince had yielded $\$ 480,000$ and the Black Warrior $\$ 385,000$. The later production came wholly from the Silver Prince.

The country rock consists of Yavapai schist, mostly fissile and sericitic, with lenses of quartzite, but the outcrops are deeply oxidized. The two parallel veins strike due north and dip $60^{\circ} \mathrm{W}$., with the schist. The Prince lies 300 feet west of the Black Warrior. Between the two there is a 50 -foot dike of light-colored porphyry.

The Silver Prince is developed by tunnels and a 400 -foot shaft about 600 feet to the north. The vein is at most a few feet wide and carries dark-brown limonitic ore. There is a little quartz, but the principal gangue mineral is a sideritic carbonate, with native silver, chloride, and some sulphides. The sulphides consist of a partly decomposed tetrahedrite rich in silver and a little chalcopyrite. The ore, which contains a little lead, was sold to El Paso and the lead smelter at Needles in 1914 and later shipped to Salt Lake City.

The shaft on the Black Warrior is said to be only 125 feet deep. The lowest levels were not visited, but it is evident that the ore on them is poorer. Here, too, the conditions are similar to those at the Peck, namely, an extraordinary concentration in the oxidized zone and impoverishment below. Considering the history of this mine, it would be rash to say that it is exhausted. More comments on the concentration in the oxidized zone of these deposits are found on page 49 .

\section{DE SOTO MINE}

The outcrops of the De Soto copper mine lie 2 miles northeast of the Peck mine, on the summit of the high ridge separating Peck Canyon from Crazy Basin. The altitude is about 5,800 feet. The main tunnel is 600 feet below the outcrop, and from it an incline 
leads down to Middleton station on the Crown King branch road. The property is owned by the same interests that control the Humboldt smelter (Southwest Metals Co.), to which the ore has been shipped. Work was discontinued in 1922, the ore bodies being considered exhausted. Most of the information given below was obtained from Mr. J. L. White, of the staff of the smelter.

The Yavapai chloritic schists strike N. $23^{\circ}$ E. at the mine and dip $70^{\circ} \mathrm{NW}$. The ore bodies, which carry pyrite-chalcopyrite ore and are contained in a chloritic schist, have yielded a total of 180,000 tons, averaging about 3.75 per cent of copper with 1 ounce of silver and 0.02 ounce of gold to the ton. The last ore treated contained 2.25 per cent of copper. There is less pyrite than at the Blue Bell

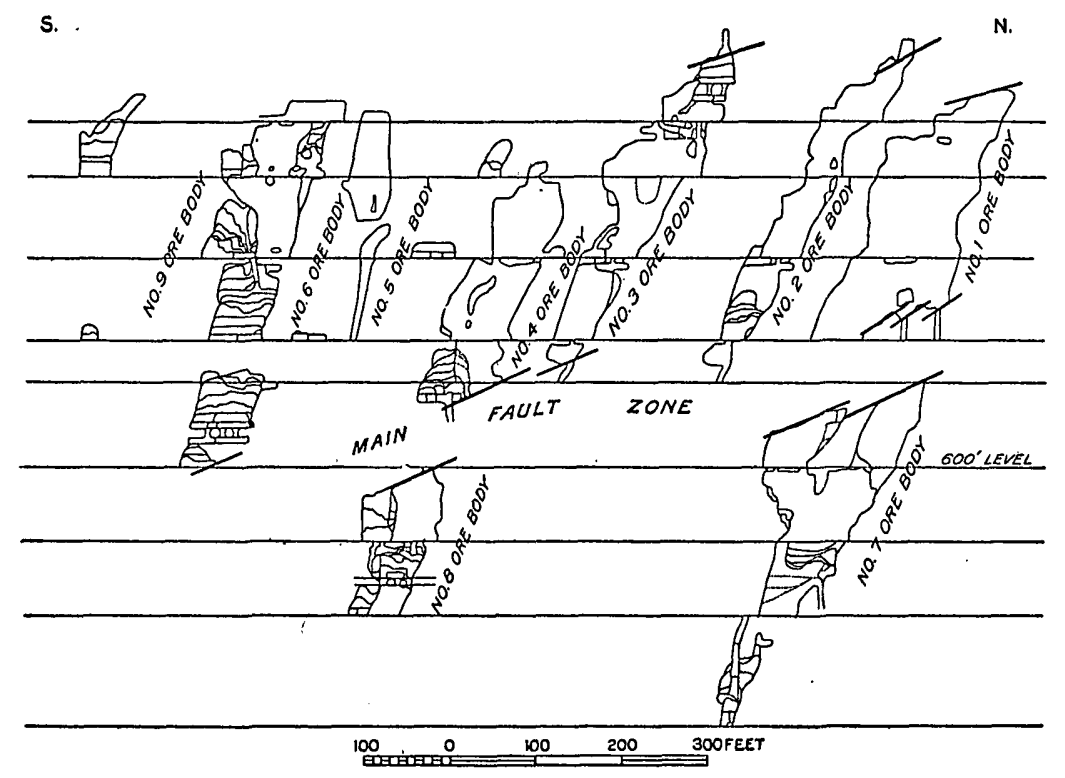

Figure 10.-Longitudinal section of ore lenses in the De Soto mine

mine, some sphalerite and galena, and occasional specimens of tetrahedrite. (See pl. 17, A.) A few prisms of arsenopyrite were observed.

The gangue is fine-grained quartz. There are also lenses of coarser quartz, much of it crushed and showing undulous extinction. Gangue and sulphides replace the schist, which is mainly chloritic with a little biotite.

The ore occur's in overlapping lenses. (See fig. 10.) On the upper levels there were seven such lenses close together, with an individual width of as much as 50 feet and a greatest length of 250 feet. Exploration extended to a depth of 300 feet below the main tunnel level, and at this depth only one small lens persisted. The total length of the ore zone is 350 feet; the total width 200 feet. 
The ore bodies are said to have been cut off in depth by a flat fault - 250 feet below the surface. The small bodies found below this depth are believed to represent the continuation of the ore below the fault. The ore bodies are shown in Figure 10, each separately, in a longitudinal projection, for they overlap so that they can not be indicated in their correct relative position.

\section{OTHER PROPERTIES}

The veins of the Gold King group, in the southern part of the district, are said to be the extension of the Gladiator vein, which is in the Pine Grove district. Near by is the Blue Bird vein. Both these deposits are in Yavapai schist.

\section{PINE GROVE DISTRICT}

'The Pine Grove district lies in the heart of the Bradshaw Mountains, in a well-timbered region, at an altitude of 6,000 to 7,500 feet. (See pl. 21, B.) Its highest point is the diorite mass of Towers Mountain. Most of the claims lie in a basin-like depression on the east side of the ridge. The district is reached by an automobile road from Prescott, 40 miles long, and by a branch railroad from Mayer, which ascends Crazy Basin and Poland Creek in a series of switchbacks. It is an old mining region, and many of the veins were very rich near the surface. The earliest properties worked were the Del Pasco, Gladiator, and War Eagle. The ores carry silver and gold.

Most of the mines are situated in granodiorite (quartz diorite, according to Jaggar and Palache), which forms a rounded mass 3 to 4 miles in diameter, intruded into Bradshaw granite and still earlier Yavapai schist. The granodiorite is cut by a series of dikes which trend north-northeast across the center of the area. In part these dikes are rhyolite porphyry, in part granite porphyry. There are also some light-colored granitic dikes which seem to be affiliated with the granodiorite; the others just mentioned appear to represent a distinctly later intrusion.

There are three prominent vein systems, which trend north-northeast and generally dip about $60^{\circ} \mathrm{WSW}$. The shoots have a tendency to pitch northward. They occur mostly in the granodiorite but continue also to the north in Yavapai schist, diorite, and mixed areas (Wildflower mine), though these harder rocks are as a rule less favorable. Few of the veins are more than 5 feet in width, and they contain a filling of predominant quartz, with some ankerite and calcite.

Much of the quartz is drusy and contains more or less pyrite, chalcopyrite, zinc blende, and galena, with some tetrahedrite. In places free gold occurs in the primary ore. Most of the ore extracted 


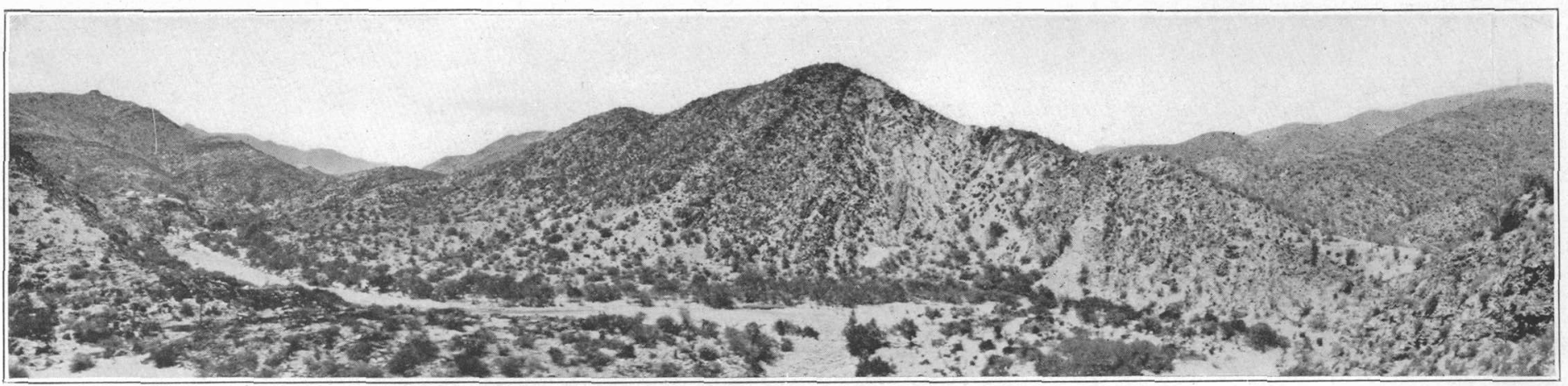

A. VIEW LOOKING UP BLACK CANYON

Mine of Howard Copper Co. in the distance

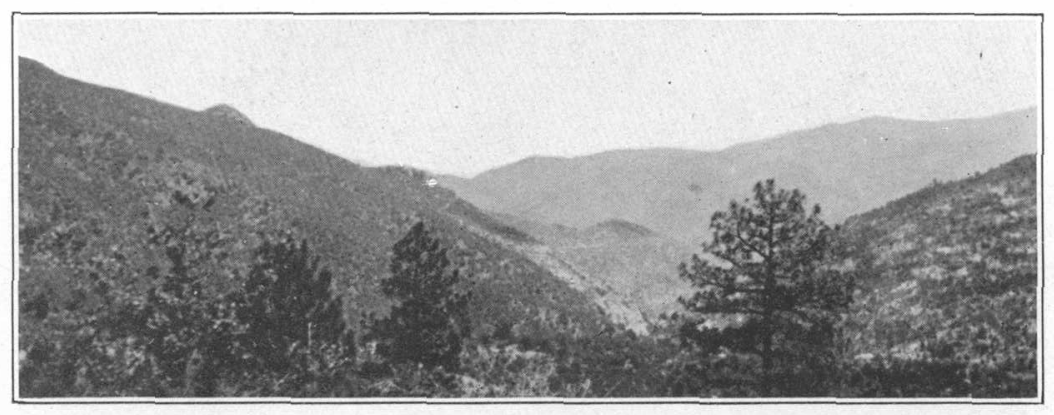

B. VIEW LOOKING NORTHEAST FROM CROWN KING STATION TOWARD CRAZY BASIN 


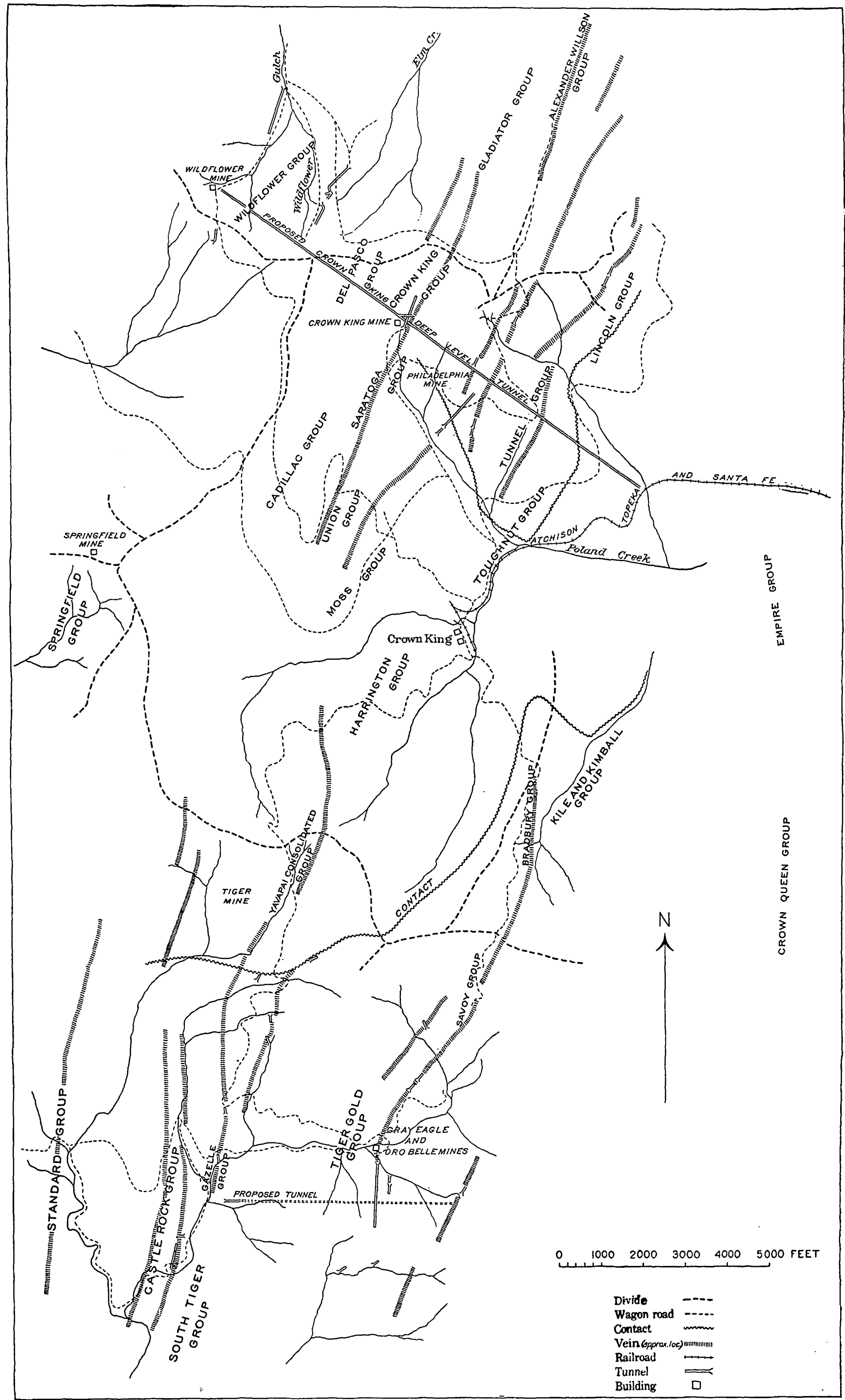

Compiled from mep published
by the Prescott Title C. Co. 
has been partly oxidized, and some of the ore is very rich, both in gold and silver, reaching assay values of $\$ 100$ a ton. Either silver or gold may predominate, or they may be present in equal quantities. Where there is much silver there is also likely to be much ankerite. The primary ores are not rich, as a rule. In few places do they seem to average better than $\$ 10$ a ton. The water level is deep. In the Crown King mine the water now stands at 250 feet below the surface.

All these veins are of a similar type, and it is believed that they have a genetic connection either with the granodiorite or with the system of rhyolite porphyry dikes. They are almost surely postCambrian and probably Mesozoic or early Tertiary.

Unusual types are the Springfield copper deposit in granite porphyry, which presents some similarity to the deposit at Copper Basin, near Prescott, and is considered Mesozoic; and the sideritesphalerite deposits in Yavapai schist on the headwaters of Bear Creek and Peck Canyon, which are probably pre-Cambrian. No pre-Cambrian quartz veins were seen in the district.

The location of the veins is shown in Plate 22.

It is difficult to give an estimate of the production of the district. Much of it was extracted in the early times. Probably it has not reached $\$ 3,000,000$. The table on page 172 shows the combined production of the Pine Grove and Tiger districts.

\section{SPRINGFIILD GROOP}

About $21 / 2$ miles west of Crown King, near the divide between Poland Creek and Pine Creek, is the Springfield group of copper claims, now owned by Harrington, Sweet \& Nelson. The altitude is from 6,400 to 6,500 feet.

The principal rock is granodiorite (quartz diorite), but as shown on the geologic map it is cut by several long dikes of light-colored porphyry with a north-northeast trend. The conditions are more complicated than is shown on the map. A short distance west of the point where the Prescott road crosses the divide are four parallel dikes of fine-grained quartz porphyry. A little farther east, where Crown King comes into view from this road, is a larger mass of granite porphyry, which occupies some flat-topped hills on the Springfield claims and which contains the prospects.

The Springfield shaft is 175 feet deep and connects with a 200foot tunnel 80 feet below the collar. The shaft discloses apparently a chimney filled with gash veins containing chalcopyrite, pyrite, and quartz, with a little purple fluorite. Two carloads of 12 
per cent ore were shipped from this small ore body, which is perhaps 30 feet in diameter. The chalcopyrite is superficially covered by chalcocite. Much trenching has been done just north of the shaft, but although disseminated chalcopyrite occurs in many places there is apparently no commercial ore in large amounts. South of the shaft is the Gorilla claim, on which a tunnel discloses a body of chalcopyrite ore of similar occurrence occupying a space of about 20 by 50 feet.

The country rock in both places is a granodiorite porphyry with phenocrysts of orthoclase, plagioclase, quartz, and biotite in a scant coarse groundmass of orthoclase and quartz. The predominating feldspars are oligoclase-andesine. Apatite is present in unusually large crystals, also magnetite and titanite. The quartz crystals contain fluid inclusions, some dark and showing, besides gas bubbles, small cubes of a colorless salt.

There are small quantities of sericite, calcite, and chlorite, but the principal product of mineralization consists of granular aggregates of albite and quartz, so that in many places near the irregular veinlets the rock has been entirely converted to an aggregate of these two minerals; the albite grains are 1 to 2 millimeters in diameter. The ohalcopyrite veinlets are very irregular and intersect the albite rock. This is a deposit of rather unusual character and very similar to the irregular deposits at Copper Basin, 12 miles west of Prescott, where the same coarse porphyry appears.

\section{WILDFLOWER MINE}

The Wildflower group of 13 patented claims lies the farthest northwest of the properties in the Pine Grove district, and the principal vein is covered by locations for 2 miles. The mine is 3,000 feet east of Towers Mountain, at an altitude of about 6,800 feet. The vein is opened for 4,400 feet. The developments consist mainly of a shaft 700 feet deep inclined $60^{\circ}$ WNW., with levels at 110, 200, 300 , and 480 feet. The 480 level connects with the Wildflower tunnel, a total distance of 3,100 feet. The mine is connected with the mill at Crown King by an aerial tramway 2 miles long. The mine was worked from 1917 to 1919 , and the production amounted to $\$ 104,000$. About 13,000 tons was milled, averaging $\$ 9$ a ton. The operating company, organized by Randolph Gemmill, was called the Bradshaw Reduction Co. High expenses incidental to war times are said to have been the cause of closing. At the time of operation the costs could hardly be brought below $\$ 7$ a ton. According to a report by W. H. Weed in 1918, there are two ore shoots; the north 
shoot contained 22,000 tons, and the south or Sabronje shoot was estimated to contain 32,000 tons. The Sabronje shoot yields ore assaying $\$ 1.20$ in gold and 6 ounces silver to the ton, $2 \frac{1}{2}$ per cent of copper, and 12 per cent of zinc.

Weed notes that the hanging wall is smooth, with striations pitching north like the shoots. He also holds that there was an earlier pyritic mineralization that introduced gold and a late reopening that brought in silver, lead, and zinc. William A. Farish, who also made a report on the property, notes that there are seven distinct veins in the group.

The country rock at the Wildflower is much mixed, quartz diorite, diorite, quartz porphyry, and amphibolite being observed.

The Wildflower is a well-defined fissure vein, with quartz-sulphide filling, in which the sulphides occur in considerable abundance. The stopes average 5 feet in width. The ratio of concentration is said to have been $5: 1$.

Though the mine was not accessible in 1922 , there was plenty of ore on the dump. The deposition was clearly accomplished by filling, drusy and comb quartz being common. The country rock is sericitized and contains particles of sulphides. In the quartz sphalerite, chalcopyrite, and pyrite are abundant in the order given. There is also a little chalcopyrite. After the sulphides and quartz had been deposited ankeritic carbonates and also calcite were deposited in the center of the vein. 'There is much crushing in places, suggesting a period of reopening of the fissure.

\section{DEL PASCO GROUP}

About 4,000 feet east of the Wildflower is the Del Pasco vein, an old-time property which was worked in the early days and which has yielded a considerable production. It is first mentioned in Raymond's report of 1874. The present owner is said to be Mrs. L. M. Jackson, of Prescott. The Del Pasco strikes north-northeast, like the other veins in this vicinity, and dips $70^{\circ} \mathrm{W}$. The main workings are on the south side of the ridge, at an altitude of 6,300 feet. Another tunnel enters from the north slope and taps the vein at an altitude of 6,600 feet. The dump at the north tunnel showed ore not unlike that of the Wildflower, with much sphalerite, pyrite, and galena. The ore is said to contain gold with little silver. An upper tunnel on the north slope at an altitude of 6,700 feet exposed a vein said to be a branch of the Del Pasco, called the Jackson Strata. This was worked in 1922 by Reoff \& Carner, who were also operating 
an arrastre. This vein is 2 to 3 feet wide and occurs in diorite intruded by a dike of typical rhyolite porphyry. The quartz is partly oxidized and is said to contain $\$ 40$ a ton.

\section{CROWN KING GROUP}

The Crown King group of eight claims includes the Crown King vein, which has yielded a higher production than any other deposit in the district. The figure given is $\$ 1,200,000$. The vein lies east of the Del Pasco and has the same north-northeasterly strike with a westerly dip.

The early owners were Place, Sheckels \& Harrington. In 1914 the mine was bought by a Mr. Murphy, and it is now controlled by the Murphy estate under the name Yavapai Consolidated GoldSilver-Copper Co. In 1916 the shaft was reopened and exploration work was done on the 480 -foot level. The last work was done in 1917-1919, when R. Gemmill, as lessee, re-treated the tailings, which yielded a production of $\$ 160,000$. In 1922 the mine was under bond to D. M. Locey.

The mill at Crown King consists of ball mills, classifiers, eight Wilfley tables, flotation cells, and electric motors. The main period of production fell between 1893 and 1900, when $\$ 474,000$ was extracted as bullion. The concentrates probably yielded more than the bullion during this period. The average value of the ore was about $\$ 40$ a ton. Lawsuits for accounting brought against the old Crowned King Co. in 1892 continued for ten years. Mr. Murphy bought the property from the court for $\$ 35,000$ cash and $\$ 25,000$ in shares of the Yavapai Consolidated Gold-Silver-Copper Co.

The Crown King mine is developed by a shaft 480 feet deep, a 913-foot tunnel 150 feet below the collar, at an altitude of about 6,400 feet, and a main shaft sunk from the tunnel level, at 525 feet from the portal, to a depth of 500 feet. There are five levels about 100 feet apart, each extending north about 1,200 feet and south from 200 to 500 feet. The water stands 250 feet below the tunnel level. All ore is said to be extracted down to the third level; some ore remains between the third and the fifth. The vein averages 2 feet in width. The ore is said to average 0.5 ounce of gold and 4 ounces of silver to the ton. Some of it was very rich with coarse gold. Assay books for 1900, toward the end of the active period, show heads ranging from $\$ 20$ to $\$ 5$. Toward the north the vein splits. There were two ore shoots, both pitching northward at fairly flat angles.

The vein cuts across the contact between granodiorite and Yavapai schist. The schist is of sedimentary origin and in places 
quartzitic. At the level of the outside shaft a strong dike of rlfyolite porphyry was observed. The ore consists of quartz filling with much sphalerite and pyrite and some chalcopyrite and native gold. The tailings from the old amalgamation mill are said to have con-

1 tained 0.3 ounce of gold and 4.5 ounces of silver to the ton, with 11 per cent of zinc, 0.8 per cent of copper, 10 per cent of iron, and 53 per cent of insoluble matter. The zinc product carried 43 per cent of zinc, 10 per cent of iron, 4.5 per cent of copper, and 15 ounces of silver and 0.6 ounce of gold to the ton. The.iron product carried 1.5 ounces of gold and 10 ounces of silver to the ton, 2.5 per cent of copper, 12 per cent of zinc, and 30 per cent of iron..$^{51}$

PHLLADELPHIA MINE

The property of the Philadelphia Mining Co. (G. P. Harrington, manager, and J. P. Sweet, superintendent) includes a number of claims covering the Nelson and Gladiator veins. The War EagleGladiator is a persistent vein traceable on the surface for at least 5,000 feet and developed by shafts and tunnels. It has doubtless yielded a considerable production of gold from oxidized quartzose ore near the surface. The strike is N. $20^{\circ}$ E. Its extension in depth is now looked for in the Philadelphia tunnel (altitude 5,975 feet).

A short distance to the east of this fissure is the Nelson vein, also traceable for a considerable distance and striking N. $10^{\circ} \mathrm{E}$. It is exposed at the shaft 250 feet deep near the top of the ridge at an altitude of 7,000 feet and has also been opened by the Philadelphia tunnel at 800 feet from the portal. The tunnel follows this vein for 3,000 feet but without reaching ore. The same vein is also opened by an upper tunnel 280 feet above the Philadelphia adit. In these workings, however, the Nelson vein shows with a filling 2 to 5 feet thick, consisting of ankerite (carbonate of calcium, magnesium, and iron), with scant sulphides; it dips generally $60^{\circ}-80^{\circ}$ W., but in places steeply east. If the Nelson vein is identical with the vein at the shaft 1,000 feet higher up on the ridge, a change has taken place in the filling, for here it shows a quartz gangue with gold and silver amounting to $\$ 20$ a ton.

Further explorations have been made to find the Gladiater vein on the tunnel level, but so far without definite result. From the Nelson vein a crosscut of 600 feet has been driven to a fault, which here appears to have cut off the main Gladiator vein. The tunnel is almost entirely in hard hornblendic Yavapai schist, which has been

s1 Weed, W. H., Mines Handbook, 1918, p. 380. 
contact metamorphosed by the intrusion of the granodiorite of the Crown King district.

\section{FATRVIEW TONNEL}

The Fairview vein, now owned by Ed. Block, of Prescott, lies high on the ridge 2 miles north of Crown King. The southerly end line of the claim has an altitude of about 7,200 feet. This vein is considered to be an extension of the Nelson vein. From this locality the outcrops drop sharply, and the lower tunnel, about 1,300 feet farther northward, is at an altitude of about 6,900 feet. This lower tunnel, which is 230 feet long, shows 3 to 4 feet of oxidized vein matter with seams of iron-stained quartz. The fissure strikes N. $40^{\circ}$ E. and dips $70^{\circ} \mathrm{W}$. It is supposed to be an extension of the Dividend and Lone Jack veins. The quartz, which is generally massive, with a few small druses, contains some pyrite and chalcopyrite. A carload of ore sacked at the portal was reported to contain $\$ 30$ a ton, mostly in gold.

The country rock is generally a black clay slate of probable sedimentary origin, striking N. $30^{\circ}$ E. and dipping steeply east. In places it contains ledges of quartzite and also several narrow dikes of light-colored granite porphyry of coarser texture than the rhyolite porphyry connected with so many of the ore deposits in this region. This association of rock was found to continue down to Dicky's ranch, on War Eagle Gulch, a ruin of a pioneer's cabin 1 mile north from the divide.

A short distance north of the Fairview tunnel a shaft is sunk on the east side of the gulch on a deposit containing siderite, magnetite, pyrite, and chalcopyrite; it looked like a lenticular mass in the slate.

\section{LINCOLN MINE}

The Lincoln vein is the most easterly in the district and in general lies parallel to the others. The main workings are 2 miles northnortheast of Crown King, at an altitude of about 7,000 feet, facing the steep slope toward Poland Creek. A good road, steadily ascending, leads up to the tunnel and mill from Crown King. The mine was idle in 1922. A 15-stamp mill with plates and concentrating tables provides for the reduction of the ore. The mine was worked in 1902 and from 1905 to 1908 , and 10,000 tons of ore is said to have produced $\$ 135,000$, net value.

The property, now in the hands of Charles T. Joslin, of Prescott, comprises four claims on the vein. It is opened by a tunnel at the mill and by a tunnel from the first gulch crossed by the Crown 
King road, at an altitude of 6,500 feet. The upper tunnel is a crosscut for 400 feet, whence the main level runs 1,627 feet southwestward to an old shaft 115 feet deep. The ore shoot pitches northward and is said to have a horizontal length of 400 feet. All ore from the surface to a depth of 100 feet below the tunnel level is said to have been extracted. The vein should be opened from the lower tunnel, which of course would necessitate moving the mill. ${ }^{52}$

The vein is contained in Yavapai schist near the contact with the great granitic area on the east. The strike is N. $18^{\circ} \mathrm{E}$; the dip steep to the west. The schist is amphibolitic in part and contains a little tourmaline, probably derived from the adjoining Bradshaw granite. Near the vein alteration has replaced the rock by sericite and ankeritic carbonates.

The ore is reported to average 5 to 6 feet in width. In the main it is similar to the ore of the Wildflower, Crown King, and other parallel veins. The gangue is chiefly earlier ankerite and later drusy quartz, between the crystals of which the sulphides are filled in. The sulphides are pyrite, chalcopyrite, sphalerite, galena, and tetrahedrite. The ore is reported as of good grade; the concentration contained 1 to 4 ounces of gold and 10 to 24 ounces of silver to the ton and 15 per cent of copper.

\section{OTHER PROPERTIES}

Two miles east of Crown King, in Horse Thief Canyon, is the deposit of the Algonkian Mines.Co. No work was being done there in 1922, and the place was not visited. It lies in the main area of Bradshaw granite. Weed's Mines Handbook of 1922 gives the following information:

Development by tunnels and shaft totals 2,400 feet. The Iower or Algonkian tunnel, 1,100 feet, runs along the dike contact, on the Anaconda claim. For 350 feet it is reported to follow the apex of an ore shoot; a raise run from the tunnel to the surface at 322 feet is said to be on the ore body. This air shaft continues as a 50-foot winze below the tunnel, and a drift north from the bottom shows galena with occasional bunches of glance and chalcopyrite.

The Silver Crown Mining Co. has the North Boulder, South Boulder, and Black Bear claims, not far east of the Crown King mill, adjoining the Tough Mountain property of the Crown King Co. The vein, which strikes north-northeast, appears to lie in the extension of the Oro Belle line of lodes in the Tiger district. The claims are developed by a tunnel 950 feet long in which some good silver ore has been found. The ore shows drusy quartz and later ankerite, with galena and pyrite.

53 'These data are in part from a report dated 1920 by E. A. Wetmore, a mining engineer, who died at Crown King in the same year. 


\section{TIGER DISTRICT}

The Tiger district adjoins the Pine Grove district on the south and drains southward into Humbug Creek. The northern part is occupied by the granodiorite (quartz diorite) of the Crown King district, and at the south end this rock borders with intrusive contact against Bradshaw granite and an intercalated belt of Yavapai schist. The schist here is largely of sedimentary origin and near the granite contact contains many pegmatite veins.

The veins form in general the southerly extension of the Crown King fissure deposits. The most westerly is the Standard group. Next east is the Tiger vein, which may be the extension of the Crown King system. On the east of this is the Oro Belle system, the continuation of which would extend just east of the Crown King mill. The deposits yield predominantly silver ores. The subjoined table shows the combined production of the Tiger and Pine Grove districts:

Gold, silver, copper, lead, and zinc produced in Pine Grove and Tiger districts, 1901-1924

[Compiled by V. C. Heikes, U. S. Geological Survey]

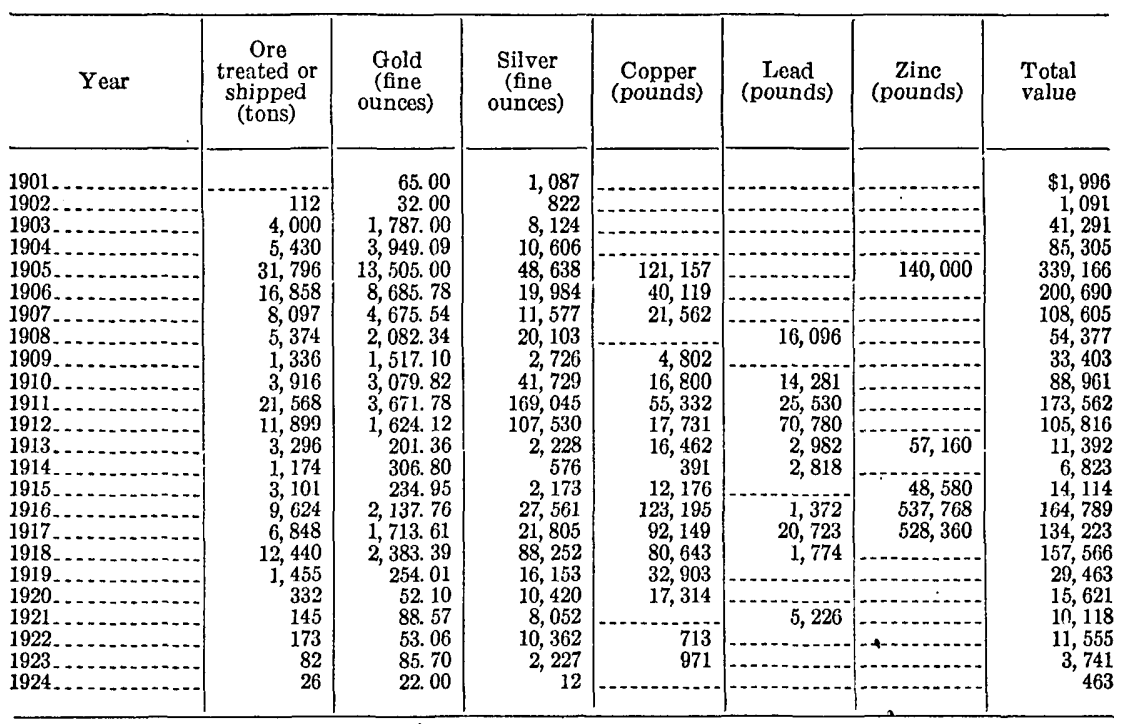

TIGER MINE

The Tiger, an old-time property, now belongs to the Yavapai Consolidated Gold-Silver-Copper Co., practically the Murphy estate. It is mentioned in the early Mint reports and in Raymond's reports. The total production, mostly in silver, is estimated at $\$ 750,000$. After having been closed for many years, the mine was bought by the Murphy estate from F. E. Harrington and partners. In 1918 
the tailings were reworked by the Randolph-Gemmill Co. and gave a yield of about $\$ 59,293$. The heads are said to have assayed 13 ounces of silver to the ton, and the concentrates obtained averaged $\$ 150$ a ton. The last work done in the mine was in 1910 and 1911. During this period 440 tons was shipped, yielding $\$ 40,700$ net. About 13,000 tons was milled and averaged 0.07 ounce of gold and 22 ounces of silver to the ton. These data were obtained from a report by William A. Farish. So far as can be ascertained, there is little ore of workable grade showing in the mine.

The Tiger mine is 2 miles south-southwest of Crown King. The road that leads to it ascends over white outcrops of granodiorite to $n$ divide 6,600 feet in altitude, from which there is a beautiful view southward toward the brushy slopes of Silver Mountain. From this divide the road descends to an altitude of 6,100 feet, where the main shaft and the mill are located.

The Tiger property comprises 9 patented and 10 unpatented claims, and the principal vein is developed by a vertical shaft 750 feet in depth. Drifts along the vein extend on the several levels for several hundred feet on each side. The country rock is granodiorite, which a short distance south of the mine is in contact with Yavapai schist.

The principal vein crops out boldly about 100 feet below the shaft in a small gulch. It is here a composite quartz lode 20 feet wide with a body of quartz 4 feet thick on the hanging wall. The strike ranges from $\mathrm{N} .10^{\circ} \mathrm{E}$. to $\mathrm{N}$. $15^{\circ} \mathrm{W}$., and the dip is $60^{\circ}-70^{\circ} \mathrm{W}$. It is claimed that the same vein has been worked 1 mile farther south under the name of the Gazelle, on a property owned by the Philadelphia Mining Co., which has a shaft 200 feet deep but no mill.

The ore, which was several feet in width, consists almost exclusively of white quartz, in places rather dense and flinty, but containing small druses and finely disseminated pyrite. Other sulphides, also sparsely distributed, are sphalerite, galena, and tetrahedrite. It is probable that the rich ore bodies contained oxidized silver minerals derived from this sulphantimonide of copper. This rich ore of the upper levels apparently broke up into several more or less primary smaller shoots in the lower levels.

The California vein, also included in the Tiger property, crops out strongly on the divide north of the road to Crown King, but seems to lie about a quarter of a mile east of the Tiger vein. The oxidized outcrops strike N. $25^{\circ} \mathrm{E}$. and $\operatorname{dip} 60^{\circ} \mathrm{W}$. The main tunnel, 100 feet below the divide, is 500 feet long and shows much milky quartz, in part fine grained and drusy, with much pyrite, chalcopyrite, galena, and sphalerite. The ore carries mostly silver but apparently is not of high grade. It is said that the California vein continues southward to a point half a mile south of the Tiger shaft, where it forms a strong outcrop averaging 10 ounces in silver to the ton. 


\section{M. \& M. VEIN}

Another vein belonging to the same system but farther east is exposed by a short tunnel on the M. \& M. claim, operated in 1922 by J. J. McNeil and Mrs. Reid. This tunnel is on the Poland Creek slope at the foot of Wasson Peak. The vein strikes N. $18^{\circ}$ E. and dips steeply west. It is a small fissure from 2 to 3 feet wide, with a pay streak about 6 inches wide. The ore, which is partly oxidized, carries mainly silver, though the thoroughly oxidized material pans free gold. The "black ore" consists of quartz and ankerite with calcite and more or less pyrite, galena, sphalerite, and tetrahedrite. Much of it shows native silver, and it contains at best $\$ 18$ in gold and 180 ounces in silver to the ton.

\section{ORO BELLE AND GRAY EAGLE MINE}

A winding road along the hillside leads from the Tiger mine to the Oro Belle and Gray Eagle. The Oro Belle mill and mine are in a canyon on the brushy south slopes of Wasson Peak, at an altitude of 5,400 feet. An old wagon road in bad condition reaches the Oro Belle mine from Minnehaha Flat and Walnut Grove. From the Oro Belle a trail leads up from the hot brushy slopes to the cool forests of Wasson Peak and to Crown King.

The Oro Belle and Gray Eagle was worked by F. E. Harrington between 1900 and 1912, but its early history goes even farther back than this date. The total production is estimated at $\$ 700,000$. Weed, in the Mines Handbook, gives the following partial figures of production: Gold, silver, and copper praduced at the Oro Belle and Gray Eagle mine,

\begin{tabular}{|c|c|c|c|}
\hline & 1907 & 1908 & 1909 \\
\hline $\begin{array}{l}\text { Gold } \\
\text { Silver } \\
\text { Copper... }\end{array}$ & $\begin{array}{r}4,313 \\
9,937 \\
19,010\end{array}$ & $\begin{array}{r}123 \\
3,639 \\
-\end{array}$ & $\begin{array}{l}1,226 \\
2,725 \\
4,820\end{array}$ \\
\hline
\end{tabular}

Some work was done, it is said, in 1915 and 1916. At the present time the property is owned by Mrs. Hattie Barnes, of New York. In 1922 the property was in a sad condition. The 20-stamp mill and the office buildings were dilapidated and wide open, serving as a stable for cattle. No caretaker was present to look after valuable surface equipment.

The Oro Belle veins are developed by eight tunnels, of which the longest extends 1,000 feet. The Gray Eagle vein is opened by a shaft 600 feet deep. 
The road from the Tiger mine to the Oro Belle soon enters highly metamorphosed, in large part sedimentary schist, which continues to the mine. In several places the schist is intruded by finegrained granite dikes. The Oro Belle vein is said to be small and was mainly worked by lessees through the several tunnels. The Gray Eagle shaft is about a quarter of a mile north of the mill; this is close to the contact of schist and Bradshaw granite, and pegmatite dikes are very abundant-in fact, the footwall of the inclined shaft is in pegmatite and the hanging wall in schist. The Gray Eagle vein is said to be from 2 to 15 feet wide, and the ore is reported to have contained $\$ 20$ in gold and 2 ounces of silver to the ton, with 1 per cent of copper.

The Big Belle is a parallel vein striking north-northeast a quarter of a mile east of the Gray Eagle. It was not visited.

\section{NORTHWARD EXTENSIONS OF GRAY EAGLE LODE}

The strong vein of the Gray Eagle continues northward across the pass and down for some distance on the slope toward Crown King, passing through the Savoy group, the Cougar, and the Bradbury group. Near the pass on the south side C. V. Carlson had recently shipped high-grade ore from a vein regarded as a spur of the Gray Eagle. At the summit Mr. Andree was taking out highgrade silver ore from a 75-foot shaft on the Cougar vein. Both these veins contain honeycombed quartz, drusy in places and oxidized in part. The ore evidently once contained ankeritic carbonates, which are now dissolved. The sparse primary sulphides are sphalerite, galena, and a little pyrite. (See pl. 14, B.) Some of this ore is of very high grade. It is said that 20 tons was shipped by Mr. Andree in 1922 and netted about $\$ 5,000$. One lot of 2 tons shipped contained 454 ounces of silver and $\$ 2$ in gold to the ton and 15 per cent of lead. The secondary silver ores appear to be cerargyrite, argentite, and native silver. A quarter of a mile north of the Cougar is the Bradbury group (Lukes mine), which in 1922 was leased by Mr. Barneguino. Some high-grade ore of similar character to that from the Cougar was shipped in 1923. The Lukes mine is developed by a tunnel, and in recent years ore worth $\$ 200,000$ is reported to have been shipped from it.

On the west side of the Gray Eagle, on the south slope, is the Fourth of July and New Jersey vein, on which considerable work has been done and from which ore has been shipped.

These veins are contained in highly metamorphosed schist, mostly of sedimentary origin; the contact with the Bradshaw granite is close by on the west, and the schist contains many pegmatite veins. 
The Bull Run mine, in the Standard group, opens the most westerly of the veins in the district. It is $11 / 4$ mile south-southwest of the Tiger mine. A tunnel exposes a north-south vein of drusy quartz containing silver, gold, and chalcopyrite.

\section{BRADSHAW DISTRICT}

There are a number of small veins on the west side of Tuscumbia Mountain, most of them in Bradshaw granite.

The Buster, owned by Charles Swazey, is a north-south vein dipping west. There are three tunnels, the longest 400 feet on the vein. The vein, of doubtful type, is 6 inches to 4 feet wide. Some ore has been milled in a 2 -stamp mill at the mine, and the grade is reported to be $\$ 20$ a ton. There has been some production from this vein.

The Cornucopia is a parallel vein, owned by M. Roland. It is reported to be 18 inches wide. A tunnel follows the vein for 350 feet. A few years ago 100 tons of $\$ 9$ gold ore from this vein was milled. There is some molybdenite in the ore.

The Mohawk, 1 mile north of the Buster, is developed by a 300foot shaft. There has been some production of gold ore, which was reduced in a small mill at Hooper.

In all these veins there is, besides free gold, a considerable amount of sulphides. The free gold is probably derived from the oxidation of the sulphides.

The Tuscumbia is an old property 2 miles north of Hooper, mentioned by Blandy ${ }^{53}$ in 1883 . This is a silver deposit which has a considerable production to its credit. It is now owned by Frank Williams and Barry Smith, of Prescott. The deposit is developed by four tunnels. The ore has a quartz and barite gangue, with silver chloride, brittle silver ore, galena, and sphalerite. The vein is evidently of comparatively recent age and is more or less similar to the N. C. 4 in the Hassayampa district.

Much quartz float is observed in the Battle Flat basin. A vein with coarsely crystalline stibnite is found there north of the Tuscumbia mine. The stibnite is reported to contain 7 ounces of silver to the ton. It is coarsely radial, is accompanied by a little quartz, and appears to be contained in a rhyolite porphyry.

\section{IIINNEHAHA FLAT AND SILVER MOUNTAIN}

Scattered mineralization is observed to the southwest of Crown King, in the mountainous, irregularly dissected area of Minnehaha Flat and Silver Mountain.

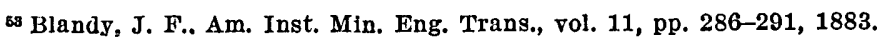


Silver Mountain is a prominent southwestward-trending ridge reaching an altitude of 6,185 feet. The Bradshaw granite is the predominating rock, capped in places by Tertiary andesitic rocks. A belt of Yavapai schist 2 miles wide trends south-southwestward from the Tiger mine toward Copperopolis. The scant mineralization is in part pre-Cambrian, in part apparently connected with the extension of the Crown King belt of dikes of rhyolite porphyry. There are practically no mines in the area. A wagon road in a bad state of repair leads northward to Prescott and another connects westward with Walnut Grove.

Minnehaha Flat is a northward-trending well timbered and watered basin on the headwaters of Minnehaha Creek, which discharges into Hassayampa River near Walnut Grove. The only inhabitant at present is George Lapham, who has been there since 1890 and whose well-ordered place is 3 miles north of the divide. Placer mining was carried on here in the eighties of the last century all the way up from the "Old Log House" to the Button mine, also in branches coming in from the east. The gold was worth about $\$ 17$ an ounce and was extracted by arrastres, sluices, and dry washes. The probable production was $\$ 100,000$, according to Mr. M. A. McKay, an old-time resident of the district. The gold is believed to have been derived from the Fortuna lode near Lapham's place.

Placers were also worked on Oak Creek 1 mile below Fenton's ranch. A silver-bearing vein, the Joker, is about a mile below the same place, and some good chloride ore is reported to have been shipped from it in 1921.

At the head of Minnehaha Creek, where there is a fine view southward into the hot, hazy valleys of the foothills, is the old Button mine. The formation here is Bradshaw granite, with some amphibolite and diorite. The Button shaft is 400 feet deep, and from it drifts extend about 650 feet northward and 100 feet southward. The work was done about 1900, and the wreck of an old 5-stamp mill still stands on the property. The deposit is a pre-Cambrian quartz vein with glassy quartz and a little pyrite, chalcopyrite, galena, and sphalerite. The wall rock of amphibolite shows no sericitization.

M. Roland has a claim on a silver-lead deposit about a quarter of a mile west of the Button mine.

About $1 \frac{1}{2}$ miles south-southwest of the Button deposit is the Boaz mine, also closed down for many years. This is an east-west quartz vein which the late F. E. Harrington opened about 1902 and equipped with a 20-stamp mill and a cyanide plant. It is said to be a "spotty" vein, "frozen to the walls." From its upper parts some ore containing about $\$ 20$ a ton in gold is reported to have been 
mined. One shaft is 650 feet deep, and drifts amount to over 2,500 feet. Without much doubt it is a pre-Cambrian vein.

Four miles southeast of the Button mine, near Copper Basin, is the Lane mine, at an altitude of 5,500 feet. This mine is said to be on a silver-bearing vein with quartz and spar. Some high-grade ore was taken out near the surface. In the mint report for 1884 it is stated that there was a 4-stamp mill on the property and that 300 tons were crushed, yielding $\$ 50,000$ in silver and gold. The owner is John Revello, who also is said to have a claim on a gold vein near the Pacific mine from which some drusy quartz rich in native gold was extracted.

The Pacific mine is 3 miles southeast of the Button mine, on Silver Creek. A shaft 400 feet deep with a crosscut to the deposit develops the property. The work was done in 1912 . The deposit is described as a "big iron dike with very little copper, gold, and silver." The country rock is schist, and the deposit evidently is a pyritic impregnation in this rock. The Pacific Copper Co. ${ }^{54}$ now defunct, owned this property. The claims show a hornblendic phase of the Yavapai schist with a porphyry dike 50 to 150 feet in width; the deposit shows gossan, much leached and traceable for 3,000 feet. The ores are said to be copper carbonate near the surface, succeeded at a depth of 50 feet by a secondary chalcocite, with bornite and chalcopyrite. The ore is estimated to contain 3 per cent or more of copper, with some silver and gold. The width of the several ore bodies is given at 9,14 , and 25 feet. The developments consist of 1,500 feet of drifts and a 500 -foot shaft.

\section{HUMBUG DISTRICT}

The Humbug district, adjoining the Tiptop on the west, contains many gold-bearing veins, but most of its production evidently came from placers, now exhausted, in Swilling, Carpenter, and Rockwall gulches, which are small tributaries of Humbug Creek. The country rock is Bradshaw granite, with many small areas of included schist and, according to Jaggar and Palache, four light-colored porphyry dikes trending north-northeast.

Information received by F. M. Morgan, an old-time resident of the district, indicates that there is little or no activity in the district at present. About 11/2 miles north of Columbia are the mine and 10-stamp mill of the Acquisition Mining Co., said to be an English enterprise. There was no production from this mine. In Rockwall Gulch M. T. Sullivan is working several claims. In the same locality is the Mountain Chief, owned by E. C. Champie, of Phoenix.

54 Weed, W. H., Mines Handbook, vol. 12, 1916. 
There is said to be 2,000 feet of development by tunnels and some ore exposed.

The production is small and intermittent. In 1913, according to V. C. Heikes, there were seven producers who mined 304 tons of ore from the Occident group, which yielded 266 tons containing 90.64 ounces of gold, 48 ounces of silver, and 21 tons of sulphide concentrate. In 1914,163 tons were mined, with a total output of $\$ 2,567$, mostly from the same mine, which has a 10-stamp mill and an adit tunnel 414 feet long. The property was closed that year.

All the veins strike east-northeast, about parallel to the Tiptop, and are of the same character, except that they carry more gold than silver. It is probable that they stand in genetic connection with the dikes of rhyolite porphyry, of which many, occur in the district.

\section{TIPTOP DISTRICT}

\section{TOPOGRAPHY AND GEOLOGY}

The Tiptop district lies in the southern foothills of the Bradshaw Mountains at an altitude of about 2,600 feet. It is difficult of access and is best reached from the road station called Canyon, on the Prescott-Phoenix Highway. A wagon road in bad shape leads across to Boulder Creek and follows this stream up for 5 miles to the Tiptop mine. An old road, now a trail, leads due west from Canyon (Gillette's ranch) across several ridges and connects with the Boulder Creek road 3 miles below Tiptop. The total distance by trail is about 10 miles, though it is only 6 miles in a straight line.

The topography is strongly marked by ridges 1,000 to 1,500 feet high left by vigorous post-Tertiary erosion, and the drainage is southward. There is little vegetation, and it is mainly of the "hot country" type, with sahuaro, mesquite, and prickly pear. A few goat ranches and some dilapidated and almost deserted mining camps represent the culture.

At their south end the Bradshaw Mountains consist mainly of the Bradshaw granite, with white outcrops, dazzling under a burning sun. On the east side of the district, west of Agua Fria River, there is a belt of Yavapai schist 2 miles wide, trending north. Pegmatite dikes are abundant, particularly near the contact. A detailed survey by Mr. Carl Barth, kindly placed at my disposal, but too late for incorporation in Plate 2, shows five long branching dikes of rhyolite porphyry between the Tiptop mine and Rockwell Gulch. These dikes are intersected and faulted by seven or eight gold and silver veins striking north and northeast.

The south end of the Bradshaw Mountains is enveloped by a series of Tertiary lava flows, comprising volcanic agglomerate, andesite, 
and basalt. These flows, which dip slightly southward, appear to have reached up to an altitude of 3,000 feet. The post-Tertiary erosion has trenched the contact to a depth of 1,000 feet.

\section{MINING}

The Tiptop district is one of the oldest in Arizona. The first reference to it is in Burchard's mint report of 1883, which notes that the Tiptop mine had been worked since 1875 and had produced $\$ 2,000,000$; also that it was (in 1883) closed for good, the ore being exhausted. The mine was reopened, however, from 1886 to 1888 . Since that time the district has remained dormant, except for a little work on small properties.

A few years ago tungsten ore was discovered in the district, and a small amount of such ore was shipped. In 1922 no work of any importance was going on. The total production of the district is estimated at $\$ 4,000,000$, which appears to be somewhat high. The history of the district is mainly the history of the Tiptop mine.

\section{TIPTOP MINE}

The Tiptop mine was located by Moore \& Corning in 1875, and a year or two later it was bought by Dan Gillette and Charles Hoffman for $\$ 60,000$. The original locators shipped some ore from it. Gillette built a mill on Agua Fria River near his ranch, and drove No. 2 tunnel. In 1878 Haggin obtained control of the company and the mine was worked successfully, yielding the bulk of its production until 1883 when, as noted above, it was considered to be exhausted. A little later it was relocated under the name Conqueror, and was held by the St. Louis-Yavapai Co. from 1886 to 1888. The mill was moved from Agua Fria River to the mine, and concentrators were installed. The mine was worked on levels 5, 6, and 8; about $\$ 250,000$ was extracted from sorting of the dump. Water was pumped from the Goat ranch on Boulder Creek, 3 miles below the property. Later, the mine was sold by foreclosure, and still later it was relocated by Wager Brothers. It is now said to be owned by Frank L. Carlisle. The property is in good condition and has for many years been cared for by Mr. O. A. Ensign, to whom acknowledgment is due for hospitality and much information.

Some picked tungsten ore is said to have been shipped in recent years, and some leasing operations have been in progress from time to time.

The developments include a shaft 800 feet deep on the incline, in which water now stands about 400 feet below the collar. The prin- 
cipal tunnel, 200 feet below the shaft, is open, with the original timbers still in good condition. The tunnel connects with the shaft.

The total production of silver and gold is at best uncertain, but perhaps $\$ 3,000,000$ would not be far from the mark. Silver predominates.

The deposit is a sharply defined filled fissure vein striking $N$. $50^{\circ}-60^{\circ} \mathrm{E}$. and dipping $65^{\circ}-70^{\circ} \mathrm{NW}$. Granite and pegmatite constitute the country rocks; here and there they contain inclusions of schist. About 500 feet northwest of the shaft, which is on the northern slope of the canyon, a dike of white rhyolite porphyry 200 feet wide crops out. It strikes north-northeast and is seen again in the canyon about 2,000 feet above the office buildings. This dike is said to "cut" the Tiptop vein, but is more probably a case of deflection than cutting. An analysis of this dike rock is given on page 23.

The vein ranges in width from a tight seam, as in the first part of the tunnel, to 6 feet in the stopes. The principal and almost only gangue mineral is quartz. In part it is a coarse comb quartz with individuals 2 or 3 inches in length; in part the quartz is fine grained, and some druses are coated with chalcedony. In general the earlier quartz is coarsely crystalline, and the later fine grained. The ore minerals, which are rather scantily distributed in the fresh ore, consist of wolframite, arsenopyrite, pyrite, sphalerite, bornite, and galena, with paragenesis in the order given, wolframite being the oldest and always found in well-crystallized crusts along the wall. The individual crystals are at most 6 millimeters in length and project into the quartz.

Within 200 feet of the surface there has been partial or complete oxidation. Some of the ore must have been very rich, and here as elsewhere it seems a little difficult to account for so extensive a concentration. The primary source of the silver was probably in the galena and perhaps in tetrahedrite, though tetrahedrite was not definitely recognized in the primary ore. Jaggar and Palache mention "antimonial silver ore" and native silver. Cerargyrite and ruby silver are said to have been most common, but the present dumps did not disclose their presence. A little manganese dioxide covers some of the oxidized specimens.

The shoots pitch northeast, so that on the lower levels they are northeast of the shaft. The vein is said to have been very hard in the upper levels, but below No. 4 is was soft and gougy.

What the lower levels will show when the mine is unwatered is of course problematical. I am not inclined to believe that the deep ore will prove to be of high grade. What proportion of gold was yielded by the deposit I am unable to say. 
Claims are located on a parallel vein about half a mile above the Tiptop mine, known as the Seventy-six. The tunnel on this claim disclosed a vein very similar to the Tiptop, largely with oxidized ore. Some stibnite was found in this vein. Some work was done in 1922 under the direction of Carl Barth.

\section{OTHER PROPERTIES}

There are several other parallel veins in the district, particularly in the "Basin," a couple of miles toward the west, but little work has apparently been done on them. Some galena veins trending northwest and carrying gold and some silver are reported to occur.

Mr. Carl Barth, on his map referred to above (p. 179), shows two long veins which, though mineralized, have yielded no great production. One of these veins, called the Big fault, extends for 6 miles from a point southeast of Malpais Hill southward to a point near Tule Creek. The other, called the Crosscut fault, trends northwestward from a point near Tiptop to Carpenter Gulch.

\section{TUNGSTEN}

It appears that practically all the veins trending east-northeast in this district carry tungsten as wolframite. There are several small veins of this kind on Tule Creek which may have yielded some production. Picked wolframite has been shipped in small amounts from Tiptop mine. F. L. Hess ${ }^{55}$ notes the occurrence of wolframite in the "Humbug district," probably Tule Creek. Ferberite is said to occur and likewise scheelite, but I have not been able to confirm these reports.

The mineral from Tiptop has a bright dark-brown streak and must contain a large amount of manganese. I was informed at Canyon that an Indian had discovered a considerable bunch of tungsten mineral north of the road to Tiptop and that a considerable quantity of this mineral was shipped during the period of high prices. This occurrence could not be located.

\section{CASTLE CREEK DISTRICT}

\section{TOPOGRAPHY}

The Castle Creek district lies in the southwest corner of the Bradshaw Mountains quadrangle. On the south and west it is adjoined by the Red Picacho, White Picacho, and Black Rock (Constellation)

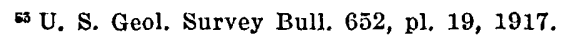


districts, which lie just outside the quadrangle. The Castle Creek district is difficult to reach; it is best accessible from Wickenburg, the distance being about 18 miles in straight line and in a northwesterly direction. A poor wagon road leads from Wickenburg to the Abe Lincoln mine, and thence trails continue to the Swallow mine and across Castle Creek to Copperopolis. A wagon road is supposed to follow Castle Creek from the Hot Springs up to Briggs.

Castle Creek is a deeply incised stream which after flowing in a southeasterly course for about 25 miles enters Agua Fria River at the extreme south corner of Yavapai County. On Castle Creek a few miles south of the border line of the Bradshaw Mountains quadrangle are the Castle Hot Springs (altitude 1,684 feet), a wellknown resort embowered in a grove of date palms and yuccas. The whole region is intensely dissected by a rather mature network of gulches intrenched between abrupt ridges from 1,000 to 1,500 feet high. Travel along the trails is difficult and arduous, and the summer climate is extremely hot. The vegetation is that characteristic of the hot belt and consists mainly of mesquite, cats-claw, sahuaro, and prickly pear.

\section{GEOLOGY}

Much of the district is covered by Tertiary volcanic flows, including volcanic agglomerate, andesite, and rhyolite tuff. These materials were poured out on the pre-Cambrian deeply eroded basement and are now dissected by the post-Tertiary erosion. The flows reach up to an altitude of about 3,500 feet, and between Fenton's and Donnelly's to 4,500 feet. North of the flows the southwestern outliers of the Bradshaw Mountains rise abruptly to 4,500 feet, and their brushy ridges connect with the complexes of Silver Mountain, Minnehaha, and Crown King.

The pre-Cambrian consists of a belt of Yavapai schist trending diagonally to the southwest corner of the quadrangle. On both sides of this is normal Bradshaw granite and in places the mixture of schist, diorite, and granite known as the Crooks complex.

The ore deposits are confined to the pre-Cambrian and include a few placers, now exhausted, the best of which were worked in American Gulch north of Briggs's ranch; pre-Cambrian gold quartz veins, represented by the Lehman deposit; gold-copper veins, deeply oxidized, with chrysocolla and specularite and in places carrying gold and silver, exemplified by the Swallow, Whipsaw, Jones, and Copperopolis properties; and lead veins, represented by the long vein that trends westward from Copperopolis.

Regarding the affiliations of the gold-copper veins and the lead veins there is much uncertainty. The only verdict possible is that 
they are pre-Tertiary. The copper-bearing veins differ from those seen elsewhere in that the oxidized ore always contains much brightblue chrysocolla, intergrown with specularite in thin plates.

A supergene origin is ascribed to the specularite because of its very intimate intergrowth with chrysocolla. As shown in Plate $15, A$, it develops in the copper silicate as minute radiating plates, many of which follow the direction of cracks in the chrysocolla. It is believed that this peculiar variety of oxidized ore owes its origin to the higher temperatures prevalent in this district of low altitude (1,500 to 3,000 feet).

Owing to the situation of the district the production has naturally been small. Some rich ore has been shipped, and some ore has been milled at the Lehman and Whipsaw mills. The total production is probably well below $\$ 500,000$, gross value.

A little smelting plant was erected many years ago at Briggs to treat Copperopolis ore, but there is no record of production.

Lately 800 acres of nitrate land has been located just north of Briggs on volcanic agglomerate and rhyolite tuff. It is not unlikely that the tuff has yielded traces of nitrate, but the probability that commercial deposits will be developed here is very small.

\section{SWALLOW MINE}

The Swallow mine, owned by John Dobler, is at an altitude of 3,225 . The place is also known as Buzzard's Roost. It is accessible from the Abe Lincoln mine, 12 miles from Wickenburg, by a road in poor repair leading down Whipsaw Creek and thence north to the head of a small gulch leading down to Castle Creek. The mine is half a mile west of the Bradshaw Mountains quadrangle, in the Congress quadrangle, but it is described here, being in the Castle Creek district. There is a 10-stamp mill on the property.

The country rock is Bradshaw granite with dikes of andesite and granite porphyry. Half a mile southeast of Buzzard's Roost is the south shaft, 225 feet deep. The vein strikes $\mathrm{N} .10^{\circ} \mathrm{W}$. and dips $70^{\circ} \mathrm{E}$. The best ore, which is a copper-stained rusty mass with chrysocolla and brown copper pitch ore, contains 1 to 2 ounces of gold to the ton. The ore averages 3 to 15 feet in width, and much of this has been milled. The ore on the d'ump carries about 8 per cent of copper and several dollars in gold to the ton.

North of the house and 300 feet above it is a shaft 300 feet deep and presumably on a different vein. Much ore has been stoped to points 150 feet north and 50 feet south of this shaft. The vein strikes N. $33^{\circ} \mathrm{W}$. and dips $60^{\circ} \mathrm{E}$. Another vein is found 100 feet north of this deposit. Still farther north and above the shaft is a tunnel driven on the same or a parallel vein. 
The vein is several feet wide, and the oxidized filling shows mainly platy specularite with oxidized copper ores, quartz, calcite, and some fluorite. It has been mined as a gold ore with free gold in the well-oxidized material. Undoubtedly poorer ore with less free gold will be found in depth.

A specimen of bismuthinite altered to bismuth ocher, said to have come from this mine, was obtained from Mr. Dobler.

Along the trail from the mine to Briggs, on Castle Creek, another parallel vein crops out, showing oxidized ore with some copper and dipping steeply west.

\section{WHIPSAW MINE}

From Castle Creek a road in poor condition leads up west to the Whipsaw mine, at an altitude of 3,200 feet, on Whipsaw Gulch. Fine-grained amphibolite crops out near Castle Creek; the mine is in schist.' The deposit is a vein a few feet wide with northwest strike and southwest dip. The oxidized ore carries gold and copper. Chrysocolla, limonite, and specularite are the minerals observed. The mine is developed by a shaft a few hundred feet deep. In 1890 a smelter was erected on Whipsaw Creek to treat the ore from this deposit. Probably it was not in operation for a long time.

\section{OTHER PROPERTIES}

On the south side of Whipsaw Creek is the Dummy, a vein with soft oxidized ore carrying gold and copper. An old gold mill imported from California was erected to treat the ore from this property.

On Buckhorn Creek 11/2 miles above Buckhorn Spring is a goldbearing vein with some lead. It is owned by Mr. Tisnerat. The ore was treated in an arrastre in the eighties. In 1922 it was under lease to Sharp \& Myers. This is said to be a vein 16 inches wide striking northeast, in diorite, and to be developed by a 100 -foot shaft. The vein is said to be rich in spots.

\section{CHAMPIE (LEHMAN) COPPER MIINE}

A deposit on which considerable work has been done lies half a mile west of Copperopolis, at an altitude of 3,400 feet. A road extends up to it from Briggs, on Castle Creek. The deposit is in amphibolite schist, injected with pegmatite and tourmaline quartz. It is developed by four tunnels within a vertical interval of 200 feet. As far as could be seen the vein strikes N. $20^{\circ}$ W. and dips $45^{\circ} \mathrm{SW}$. The lowest tunnel is caved. The ore consists of brown limonite with chrysocolla and specularite. The mine was devel- 
oped by Gus Lehman, who shipped no ore. In 1917 E. C. Champie is said to have shipped four carloads of 20 per cent ore, hauling it to Hot Springs Junction, a distance of 34 miles.

On the trail from Lehman's mill to Copperopolis are several prospects with similar ore. One of them showed 1 foot of chrysocolla ore in a vein along an andesite dike in schist and pegmatite.

\section{COPPEROPOLIS}

The locality with the ambitious name Copperopolis is 2 miles northeast of Briggs, at an altitude of 3,200 feet, at the north edge of the Tertiary lava and at the foot of the granite mountain that rises 1,300 feet above the town site. At present there is just one house in the town, and that is deserted. (See pl. 23, B.)

The remarkable outcrops at this place long ago attracted attention. At present the five or seven claims are said to be held by R. D. O. Johnson and looked after by Dr. Morrison, of Phoenix.

There are two prominent outcrops at Copperopolis. The upper one is 1,000 feet north of the town and is trenched 100 feet deep by Copperopolis Creek. It is developed by irregular workings and a 200 -foot shaft, sunk in 1880 and now caved. The country rock consists of granite and pegmatite, greatly oxidized. The ledge seems to be 100 feet wide with many seams. It strikes $\mathrm{N} .60^{\circ} \mathrm{W}$. and dips southwest. The ore consists of limonite and bright-blue chrysocolla. Some ore is said to have been shipped to the Briggs smelter and some shipped to outside points. The production was probably small.

Below this outcrop the rock is andesite for 400 feet, to the point where the so-called "great lead vein" crosses. This is a zone perhaps 75 feet wide and whether the country rock is andesite or granite could not be definitely decided. At any rate the ledge matter contains granitic material. An old tunnel opening this lode from creek level is caved, but on the dump is a considerable amount of black oxidized lead ore, probably carbonate and sulphate mixed.

This lead vein crops out also in the low saddle half a mile toward the west, where it strikes about N. $70^{\circ}$ W. A little work has been done here, but the openings are caved. The ore shows galena and anglesite with some manganese dioxide in barite gangue. The width is not shown but is probably 8 or 10 feet. The ore is said to assay about 4 ounces of silver to the ton. More work has been done on this vein a mile farther to the west, and it is said to be traceable to Crown Point, in the Congress quadrangle. 


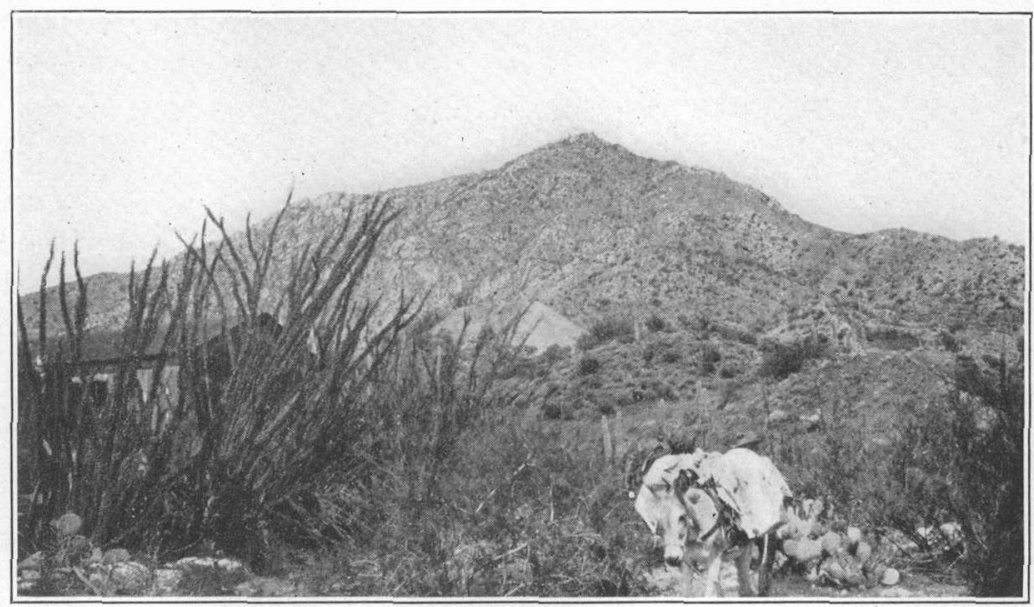

A. VIEW LOOKING NORTH TOWARD LEHMAN MOUNTAIN FROM COPPEROPOLIS

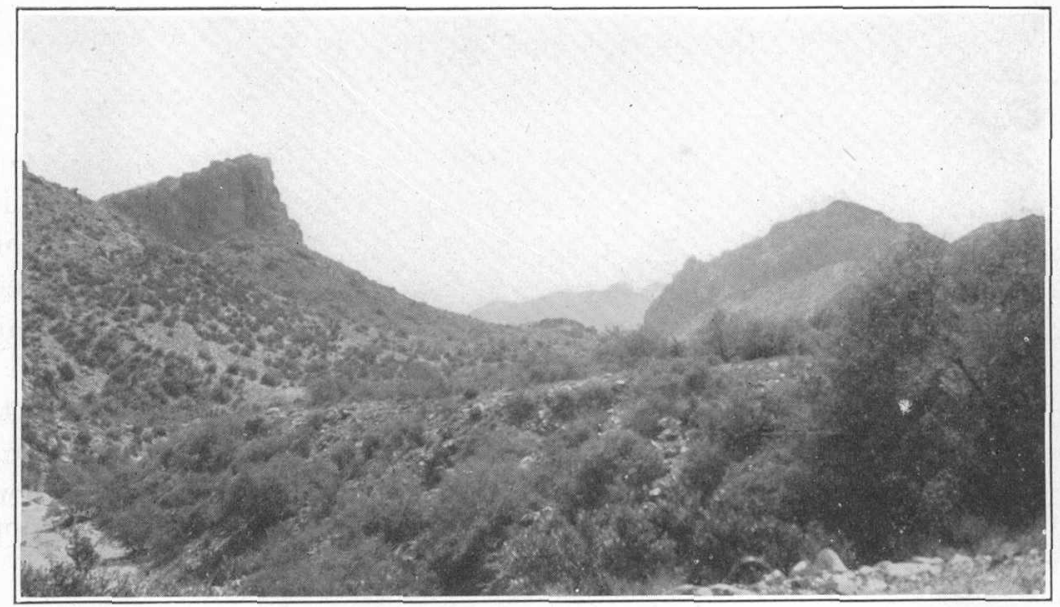

$B$. VIEW LOQKING SOUTH FROM COPPEROPOLIS TOWARD THE RHYOLITE FLOWS 


\section{LEHMAN'S MINE}

High on the shoulder of the granite mountain rising north of Copperopolis, which might well be called Lehman Mountain (altitude 4,400 feet), is Lehman's gold quartz mine. (See pl. 23, A.) For many years this was owned by Gus Lehman, a pioneer of the district, who died in 1914, perishing of thirst on the desert between this place and Phoenix. At present the property is held by E. C. Champie. The exact location is a quarter of a mile due east of the gap just north of Lehman Mountain, and the altitude is about 4,200 feet. The trail leading up from Copperopolis ascends 500 feet over andesite to a point where the granite crops out.

The developments consist of two tunnels, 50 and 100 feet below the outcrop. Some ore has been extracted and packed on burros to the 5 -stamp mill on Spring Creek indicated on the map. The country rock is granite with some pegmatite and schist. The strike of the veins is $\mathrm{N} .10^{\circ} \mathrm{W}$., and the $\operatorname{dip} 25^{\circ} \mathrm{W}$. The upper workings show three parallel veins close together, 2 feet, 6 inches, and 6 inches wide. The ore is a massive glassy quartz, stained by limonite and corroded by descending waters. There are no sulphides left, but much finegrained tourmaline is intergrown with the quartz. 



\section{INDEX}

A

Actinolite, occurrence of

Page

26

Adularia, occurrence of....................... 25

Agua Fria district, general features of....... 146 minor properties in....................... 148-149

Albite, occurrence of............................ 25

Amulet mine, description of................... $\quad 112$

Anglesite, occurrence of........................ $\quad 30$

Ankerite, occurrence of ........................ 25

Argentite, occurrence of ...................... 28

Arizona-Binghampton $\mathrm{Co}$, mill of, plate showing .......................... 146

Arizona National mine, description of..... 129-130

Arsenopyrite, occurrence of................... 29

Azurite, occurrence of ....................... 30

B

Barite, occurrence of

1

25

Benedict, P. C., cited ........................ 99-100

Big Pine mine, description of.............. 115-116

Bigbug Creek, view looking north from..... 73

Bigbug district, general features of.......... 126-127 production in.

Binghampton mine, equipment and production of.

geology and ore of

146

plates showing. 146-148

Bismuthinite, occurrence of

Black Canyon, plate showing

Black Canyon district, production in......... 153

minor prospects in......................... $\quad 156$ topography and geology of.............. 152-153

Black Fills, features of...................... 8,12 veins of unusual types in................ 39-40

Black Hills district, location and rocks of.... 97 minor prospects in.................. 100, 101-102

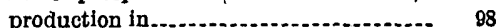

Black Warrior prospect, location of.......... 101

Blue Bell mine, geology of.................. 144-145

history and development of .............. 143

longitudinal section of .................... 144

ore of....................................... 145

photomicrographs of................. 72, 146

production from............................ 143

view looking south from ................ 146

Blue Dick mine, description of . ............ 117-118

Boggs mine, description of................. 139-140

Bornite, occurrence of ....................... $\quad 29$

Bournonite, occurrence of..................... 28

Bradshaw district, minor prospects in....... 176

Bradshaw granite, nature and occurrence of. 16

Bradshaw Mountains, features of........... 8, 12-13 plates showing............................ 8, 146

Bradshaw Mountains quadrangle, geologic map of . . . . . . . . . . . . . . . . . .

Yavapai sehist in 17-19

"Breaks, Verde," location of
Page

Pup mine, location of ............... 100

Burchard, H. C., cited...................... 62

Butternut mine, description of............... 142

Buzzard mine, description of .................. 118

C

Calcite, occurrence of......................... 25

Cash mine, description of ................... 121-122 ore from, photomicrograph of............ 87

Castle Creek district, geology of ............ 183-184 minor properties in..................... 185 topography of .......................... 182-183

Cerusite, occurrence of ...................... $\quad 30$

Chalcocite, occurrence and features of....... 27 zones of, occurrence of ................... 50-51

Chalcopyrite, occurrence of................... $\quad 29$

Champie copper mine, description of...... 185-180

Chaparral district, mines in ................ 127-134

Cherry Creek district, geology of........... 102-103

history of ............................ 104-105

quartz veins in, workings on........... 103-104 workings near the Monarch mine....... 105-106

Chlorite, occurrence of............. 26

Chrysocolla, occurrence of.................... $\quad 30$

Conger mine, location of................... 106

Consolidated Bodie mine, description of..... 126

Contact-metamorphic deposits, occurrence and features of.................... 36-37

Copper, occurrence of ........................ $\quad 30$ production of ........................... 6,32

Copper Chief Mining Co., ore of, photomicrograph of...................... $\quad 72$

property and ores of .................... 91-92

Copper deposits, pyritic, character and form of ................................. 32-33

pyritic, origin of ......................... 35 replacement process producing....... 33-34

Copper Queen mine, description of........... 148

Copperopolis, lodes at......................... $\quad 186$

Cougar vein, photomicrograph of ore from... $\quad 87$

Covellite, occurrence of........................ $\quad 27$

Crazy Basin, view looking from Crown King station toward................... 164

Crook vein, description of .................. 124-125

Crown King claims, description of......... 168-169

Cumberland mine, description of ............. 150

Cuprite, occurrence of ....................... $\quad 30$

D

Davis mine, description of................. 110

De Soto mine, description of.............. 162-164 photomicrograph of ore from ............ 146

Del Pasco claims, description of ............ 167-168

Dikes, occurrence of .................... 12-13,16, 22-24 rocks of........................... 22-24, 69 rhyolite, in the Bradshaw Mountains... 12-13 
Page orite, features of . .......... 17

In the United Verde mine, features of....

Dolomite, occurrence of

Dos Oris mine, description of

Drainage of the area $118-119$

Dundee-Arizona Copper Co., property, and ores of $90-91$

Dunkirk mine, location of ................ 119

\section{$\mathbf{E}$}

Epidoto, occutrence of.

Equawor Mining \& Smelting Co., property of. 91, 92 E'rosion, post-Paleozoic, effects of.

\section{F}

Fairview tunnel, description of

Faults, occurrence of .

Federal mine, description of

$8,11,12$

Finlay, J. R., cited.

Fluorite, occurrence of.

French Lily mine, description of

\section{G}

Galena, occurrence of

Garnet, occurrence of........................ 26

Gladstone mine, properties near.......... 132-133

Gold, occurrence of .......................... 30

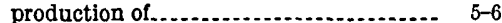

Gold Note claims, description of............. 151

Gold quartz veins, mineralization of........ $\quad 39$ nature and distribution of ........... 37-39

production from......................... 38

Gold-quartz-tourmaline replacement deposit, features of

Gold veins, later, distribution of............. 46-47

later, general features of. . . ............. 41-43

mineralization of .................. 46

proportion of gold to silver in....... 45

rocks associated with.............. 45-46

unusual types of................. 48

Golden Idol mine, description of............. 106

Goodwin properties, description of......... 151-152

Grand Wash Cliffs, depression west of....... 11

Granodiorite, nature and occurrence of ..... 21-22 photomicrograph of..................... 36

Gray Eagle lode, extensions of............... 175

Gray Eagle mine, description of ........... 174-175

Groom Creek district, production in......... 115 properties in............................ 113-114

Gypsum, occurrence of.

\section{H}

Hackberry mine, description of

Hassayampa district, location and ore deposits of

minor prospects in

114-115

prospects in 126

production in............................ 115

Henrietta mine, description of ........... 137-139 plate showing.

History, geologic, outline of.................. $9-14$ mining, sketch of........................ 2-5

Howard Copper Co., property of .......... 154-155 property of, plate showing ....... 164

Howard Silver Co., property of............... 159

Humbug district, veins and placers in ..... 178-179
I

Page

Inspiration"mine, llocation of

Iron King mine, description of.............. 127-128

Iron Queen mine, description of . . .......... 140-141

ore from, photomicrograph of............ $\quad 140$

J

Jaggar, T. A., Jr., and Palache, Charles, cited .................... 17, 21, 121-122

Jerome district, panoramic view of............ 32 Jerome quadrangle, geologicimap of . .... In pocket.

Yavapai schist in ......................... 19-20

Jerome-Verde Development Co., property and history of.................... 88-89

Jersey Lily mine, description"of .............. 117

\section{K}

Kaolin, occurrence of........................ 31

Kay Copper Corporation, property of....... 155

I.

Lavas, Tertiary, features of............... 8-9, 13-14

Lead, production of .......................... 6,28

Leghorn mine, description of ................ 107

Lehman Mountain, location of............... 187

plate showing............................ 186

Lehman's mine, description of................ 187

Limonite, occurrence of ...................... 31

Lincoln mine, description of ................ 170-171

Logan mine, description of .................. 107

Lookout mine, description of ................ $\quad 130$

\section{M}

M. \& M. vein, description of .................. 174

McCabe-Gladstone mine, description of ... 130-132

Magnetite, deposition of....................... 35-36 deposits of, in the Black Canyon district. $\quad 156$ occurrence of ............................. 26,36

Malachite, occurrence of..................... $\quad 30$

Marcasite, occurrence of...................... 27

Mark Twain mine, description of . ......... 117-118

Metals, production of....................... 5-6

Metamorphosed sediments in the United

Verde mine, features of........... 66-68

Mine water, in the United Verde mine... 66

Mingus Mountain Copper Co., property of.. 100

Mining, history of............................ 2-5

Mining districts near this area................ $6-7$

Minnehaha Flat, lode mines and placers in. 176-178

Molybdenite, occurrence of................... 27

Monarch mine, description of ................ 105

Monzonite, age of ........................... 17

Morgan mine, description of ................. 152

Mount Union mine, description of ........... 125

Mountain region, relation of, to the plateau province......................... 10-13

Mudhole mine, description of ................ 112

$\mathrm{N}$

N. C. 4 mine, description of................. 117

0

Ore, primary, grade of

Ore deposits, general classification of ....... 31 minerals of ................................ 24-31 persistence of, in depth................... 51-53 pre-Cambrian, descriptions of ........... 31-41 Oro Belle mine, description of ............. 174-175 Oxidation in ore deposits, features of......... 49-50 
Palache, Charles, with Jaggar, T. A., jr., cited .................... 17, 21, 121-122

Paleozoic formations, features of.............. 9-10

Peck district, general features of ............ 160 production from........................ 160

Peck mine, description of.................... 161 properties south of ...................... 160

Peneplain, pre-Paleozolc, deposition on...... 10 pre-Paleozoic, height of.................. 10-11

Philadelphia mine, description of .............169-170

Physiography of the area.................... 7-9

Pickerell mine, location of ..................... 123

Pine Grove district, map showing location of claims in................... 164

minor properties in.......................171-172

ore deposits in . . . ......................164-165

production in ............................. 165

Placer deposits, source and distribution of.-. 53-54

Placers in the Black Canyon district, yield of 157

Plateau province, relation of, to the mountain region............................. 10-13

Pocahontas mine, description of.............142-143

Poland, properties near......................134-136

Pre-Cambrian ore deposits, descriptions of . . 31-41 unusual types of ........................... $39-41$

Pre-Cambrian rocks, kinds of . .............. 14-16

Prescott district, geology of . . . . . . . . . .........107-108

placers worked in.......................108-109

quartz veins in, prospects on............ 108

Production of metals in the area............. $5-6$

Proustite, occurrence of ....................... 29-30

Providence, properties near . . .................134-136

Pyrargyrite, occurrence of.................... 29-30

Pyrite, occurrence of ........................... 26-27

Pyrrhotite, occurrence of...................... 27

\section{Q}

Quartz, occurrence and features of

"Quartz porphyry" in the United Verde mine, features of 68-69

Quartzite, outcrops of, in Yavapai schist, plates showing

R

Rainbow lode, description of.

Ransome, F. L., cited.

Reber, L. E., jr., cited.

Rhyolite flows, plate showing.

Rhyolite porphyry, dikes of

Richinbar mine, description of

Rickard, T. A, cited r. 157

Ruth mine, description of....................116-117

Rutile, occurrence of ........................ 25

\section{$\mathrm{S}$}

Scope of the report............... 1-2

Senator mine, description of.................120-121

Sericite, occurrence of ........................ 25

Seventy-six vein, description of .............. 182

Shea Copper Co., property and ores of...... 92-93

Sheldon mine, description of ...............110-111

Shylock mine, description of .................99, 100

Siderite, occurrence of.

25

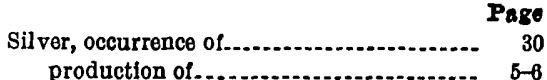

production of

Silver Cord vein, description of................ 158

Silver Mountain, mineralization on ......176-178

plate showing ........................... 8

Silver veins, later, general features of ........ 41-43

later, with barite, occurrence of........... 43-44

with quartz gangue, occurrence of... 41-45

Sirdevan, W. H., with Smith, H. D., cited .. 70-71

Smith, H. D., and Sirdevan, W. H., cited... 70-71

Specularite, occurrence of...................... 29

Sphalerite, occurrence of................... 27-28

Springfteld claims, description of ........... 165-166

Starlight claims, description of............... 123-124

Stibnite, occurrence of ....................... 28

Stoddard mine, description of................ 148

Storm Cloud mine, description of........... 122-123

Swallow mine, description of ................ 184-185

ore from, photomicrograph of............ $\quad 140$

Swastika mine, description of................. $\quad 162$

\section{$\mathrm{T}$}

Tapeats sandstone, deposition of............... 10

Tennantite, occurrence of...................... 28-28

Tetrahedrite, occurrence and features of..... 29

Thunderbolt mine, description of........... 158-159

Tiger district, map showing location of claims

ore deposits in in ................................... 164

production in.............................. 172

Tiger mine, description of .................. 172-173

Tillie Starbuck mine, description of....... 110-120

Tiptop district, mining in.................... $\quad 180$ topography and geology of.............. 178-180 tungsten in.......................... 180, 181, 182

Tiptop mine, description of................. 180-181

Tourmaline, occurrence and features of...... 26

Tungsten, occurrence of, in the Tiptop district...................... 180,181, 182

Turkey Creek district, general features of.... 149 production in......................... 150

Turkey Creek station, deposits east of..... 154, 158

\section{U}

Union mine, description of ................ 133-134

United Verde Copper Co., dividends paid by. $\quad 64$ production by ............... 63

United Verde Extension mine, development

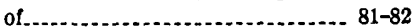

geology of. ................................. 82-83

1)cation and history of................... 79-81 ore bodies of .............................. 83-85

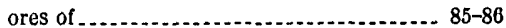

origin of ............ 86-88

photomicrographs of................ $\quad 86$ production and dividends from........... 82

United Verde mine, development of......... 64-65 dikes in ................................... 69

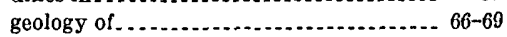
history of ............................... 61-63 location of ..................................... 61 ore body of ............................. 69-70 origin of $\ldots$

$$
68508-26-14
$$


United Verde mine, ores of, classification for smelting.

paragenesis of minerals. structure in

types of.

production of. pyritic ore from, photomicrographs of.... 72 smelter of. water from.

Vanadinite, occurrence of.

Vassar, Helen, analysis by.................... 23

Verde district, general geology of............ 55-56 geology and mines of...................... 54-97 minor claims and prospects in........... 93-97 ore deposits in paleozoic sediments in ....................... 58-59 pre-Cambrian rocks in.................... 56-58 production of............................ 60 property map of.......................... 60 Tertiary lake beds in.................... $59-60$ Tertiary lavas in........................ 59 Verde fault, rocks bordering................. $59-60$ Verde formation, deposition of.
Page

Verde Valley, plate showing.................. 73

Volcanic flows, areas covered by.

13-14

W

Walker, properties near

113

Walker district, history and production of..109-110

War Eagle mine, description of............. 150-151

Water level, depth to.......................... 49-50

Wenström, Olof, cited....................... 89

Whipsaw mine, description of................. $\quad 185$

Wildflower mine, description of............ 166-167

Wolframite, occurrence of...................... 30-31

\section{$\mathbf{Y}$}

Yaeger mine, description of.................. $88-\theta 9$ ore deposit of .............................. 40

Yavapai County, production of metals in.... 5-6

Yavapai schist, correlation of................. 20-21 nature and occurrence of.............. 17-20,56 outcrops of, plates showing............. 146, 147 photomicrograph of....................... 36

Z

Zinc, production of ........................ 6,28 